\title{
ZUSES
}

science for a changing world

\section{A Quarter Century of Research on the Colorado Plateau- A Compilation of the Colorado Plateau Biennial Conference Proceedings for 1993-2015}

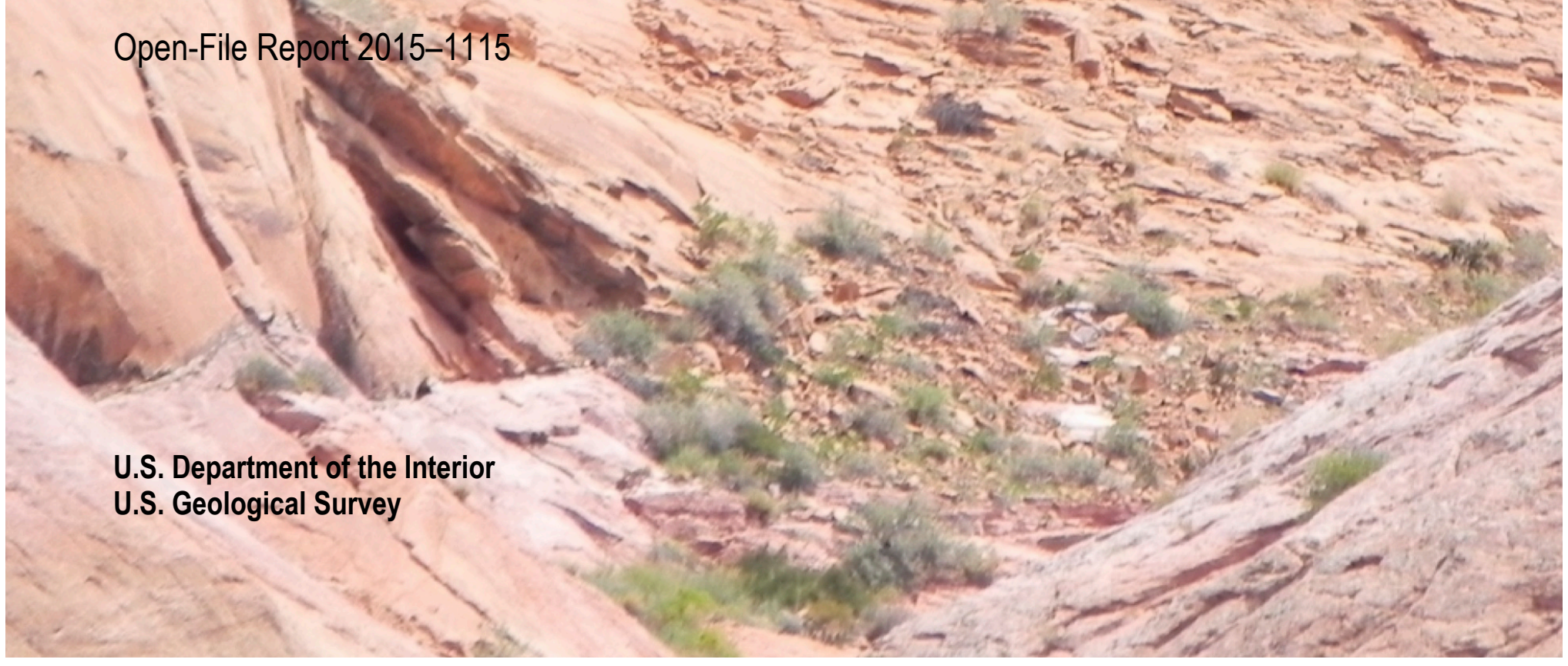


COVER

Photograph of Inscription House, Navajo National Monument in northeastern Arizona (U.S. Geological Survey photograph). 


\section{A Quarter Century of Research on the Colorado Plateau-A Compilation of the Colorado Plateau Biennial Conference Proceedings for 1993-2015}

Compiled by Charles van Riper III, Charles A. Drost, and S. Shane Selleck

Open-File Report 2015-1115

U.S. Department of the Interior

U.S. Geological Survey 


\title{
U.S. Department of the Interior SALLY JEWELL, Secretary
}

\section{U.S. Geological Survey \\ Suzette M. Kimball, Acting Director}

\author{
U.S. Geological Survey, Reston, Virginia: 2015
}

For more information on the USGS-the Federal source for science about the Earth, its natural and living resources, natural hazards, and the environment-visit http://www.usgs.gov/ or call 1-888-ASK-USGS (1-888-275-8747).

For an overview of USGS information products, including maps, imagery, and publications, visit http://www.usgs.gov/pubprod/.

Any use of trade, firm, or product names is for descriptive purposes only and does not imply endorsement by the U.S. Government.

The last six books of the Colorado Plateau series from which abstracts and introductory materials included in this compilation were published by the University of Arizona (UA) Press. The full articles and introductory text from the UA Press publications are copyrighted and thus cannot be provided herein. The UA Press has granted the U.S. Geological Survey (USGS) permission to reproduce the abstracts and introductory materials as they were submitted. Abstracts authored entirely by non-USGS authors do not represent the views or position of the USGS or the U.S. Government and are published solely as part of this volume.

Suggested citation:

van Riper, C., III, Drost, C.A., and Selleck, S.S., compilers, 2015, A quarter century of research on the Colorado Plateau-A compilation of the Colorado Plateau Biennial Conference proceedings for 1993-2015: U.S. Geological Survey Open-File Report 2015-1115, 186 p., http://dx.doi.org/10.3133/ofr20151115. 


\section{Contents}

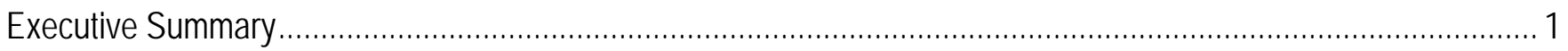

Introduction

Literature Cited and Author List ............................................................................................................ 4

Proceedings of the First Biennial Conference on Research in Colorado Plateau National Parks edited by Peter G.

Rowlands, Charles van Riper III, and Mark K. Sogge ............................................................................ 6

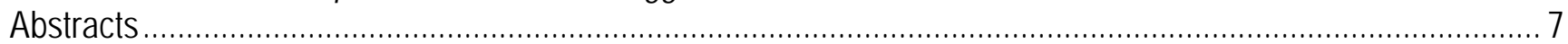

Proceedings of the Second Biennial Conference on Research in Colorado Plateau National Parks edited by Charles

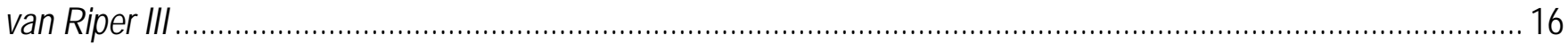

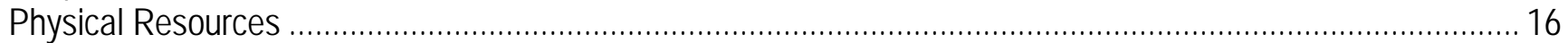

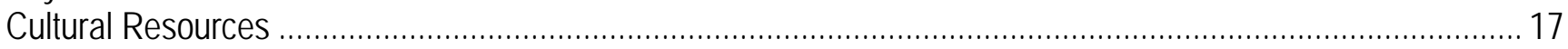

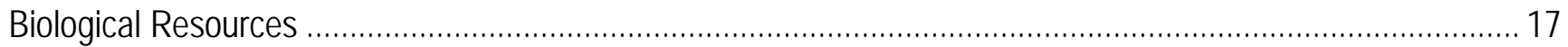

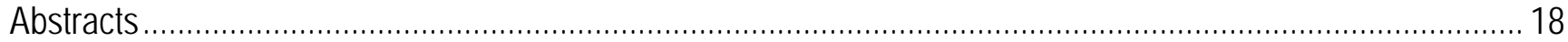

Proceedings of the Third Biennial Conference of Research on the Colorado Plateau edited by Charles van Riper III

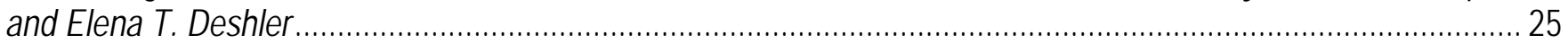

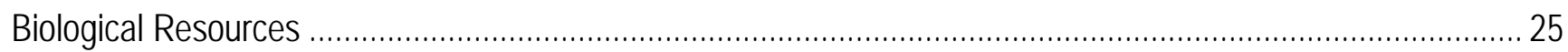

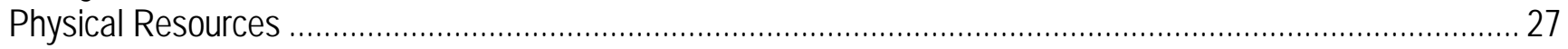

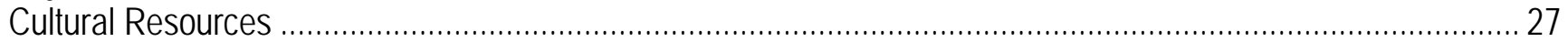

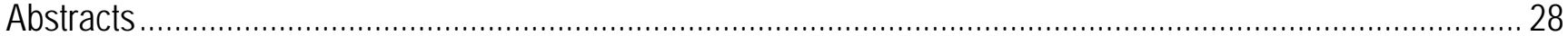

Proceedings of the Fourth Biennial Conference of Research on the Colorado Plateau edited by Charles van Riper III

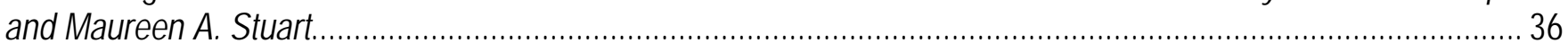

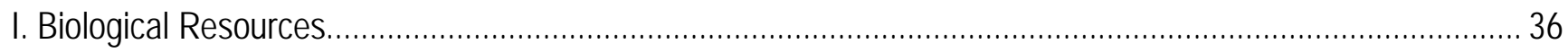

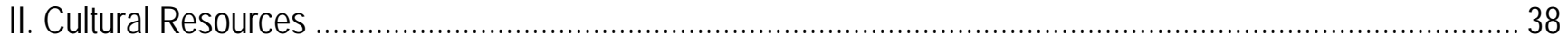

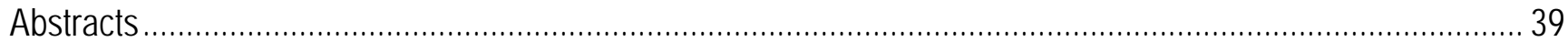

Proceedings of the Fifth Biennial Conference of Research on the Colorado Plateau edited by Charles van Riper III,

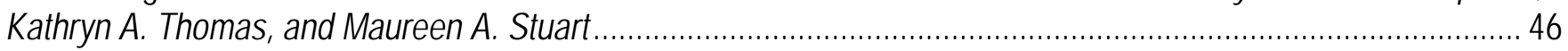

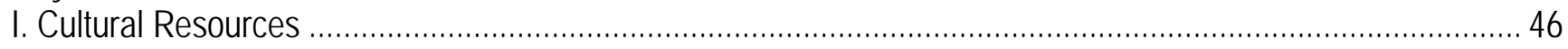

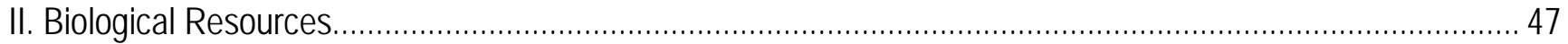

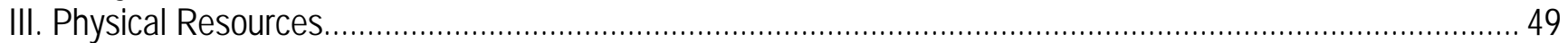

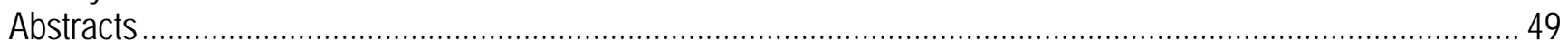

Proceedings of the Sixth Biennial Conference of Research on the Colorado Plateau: Cultural, Biological and Physical Research on the Colorado Plateau edited by Charles van Riper III and Kenneth L. Cole ......................................56

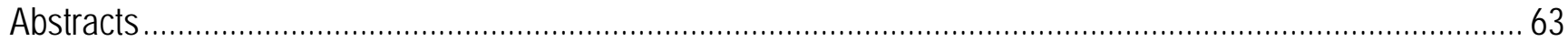

Proceedings of the Seventh Biennial Conference of Research on the Colorado Plateau: Biophysical, Socioeconomic and Cultural Research on the Colorado Plateau edited by Charles van Riper III and David J. Mattson ................... 80

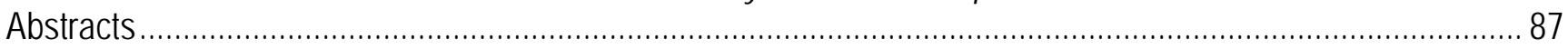

Proceedings of the Eighth Biennial Conference of Research on the Colorado Plateau: Integrating Research and

Resources Management for Effective Conservation edited by Charles van Riper III and Mark K. Sogge .............. 106

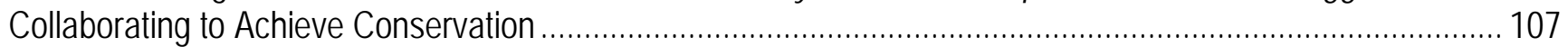

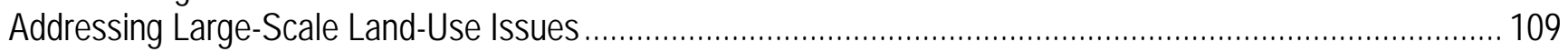

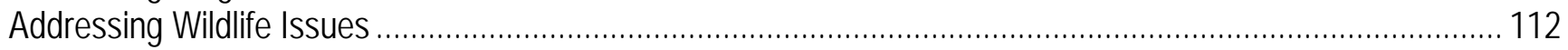

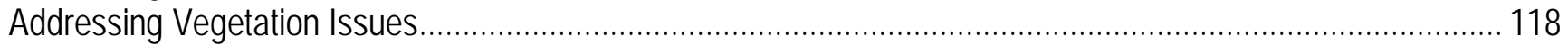

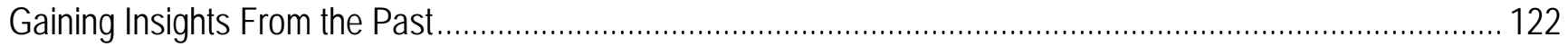

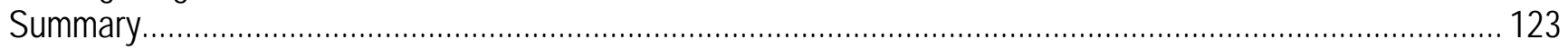

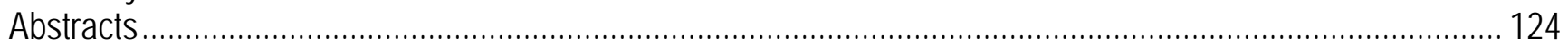


Proceedings of the Ninth Biennial Conference of Research on the Colorado Plateau: Shaping Conservation Through the Integration of Research in Resources Management on the Colorado Plateau-A Synthesis edited by Charles van Riper III, Brian F. Wakeling, and Thomas D. Sisk .......................................................................... 139

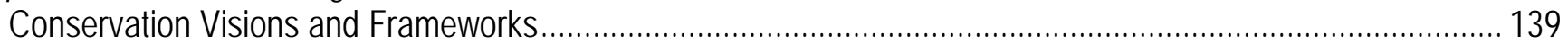

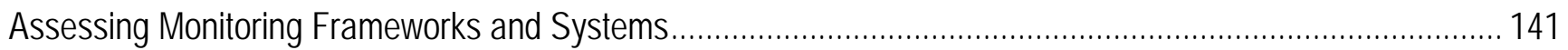

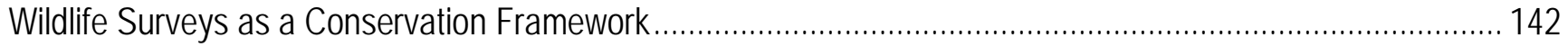

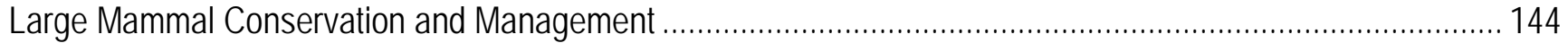

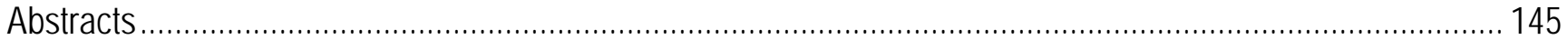

Proceedings of the Tenth Biennial Conference of Research on the Colorado Plateau-Research, Environmental

Planning, and Management for Collaborative Conservation edited by Charles van Riper III, Miguel L. Villarreal,

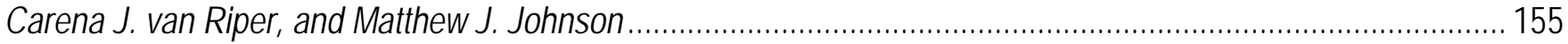

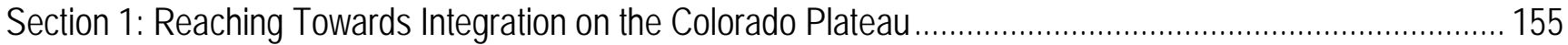

Section 2: Assessing Natural and Man-Made Threats to Ecological Systems ............................................. 157

Section 3: Synergy Between Human and Environmental Systems_Planning and Management Frameworks .. 159

Section 4: Tools for Conservation and Collaborative Decision-Making .......................................................... 162

Section 5: A 20-Year Evaluation of the Colorado Plateau Biennial Conference.................................................. 162

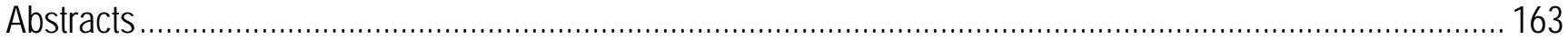

Proceedings of the Eleventh Biennial Conference of Research on the Colorado Plateau edited by Laura F. Huenneke,

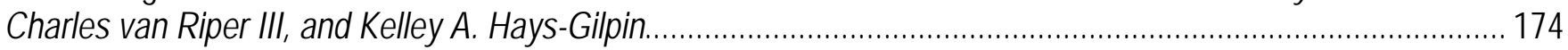

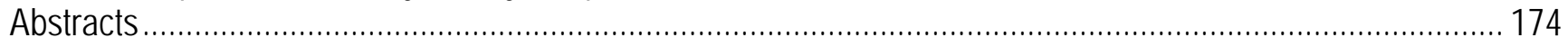

\section{Appendix}

[Available only online as a .csv file at http://sbsc.wr.usgs.gov/cprs/news_info/meetings/biennial/proceedings/proceedings.asp]

List of authors that have contributed chapters to one or more of the 11 Colorado Plateau Biennial Conference proceedings volumes. 


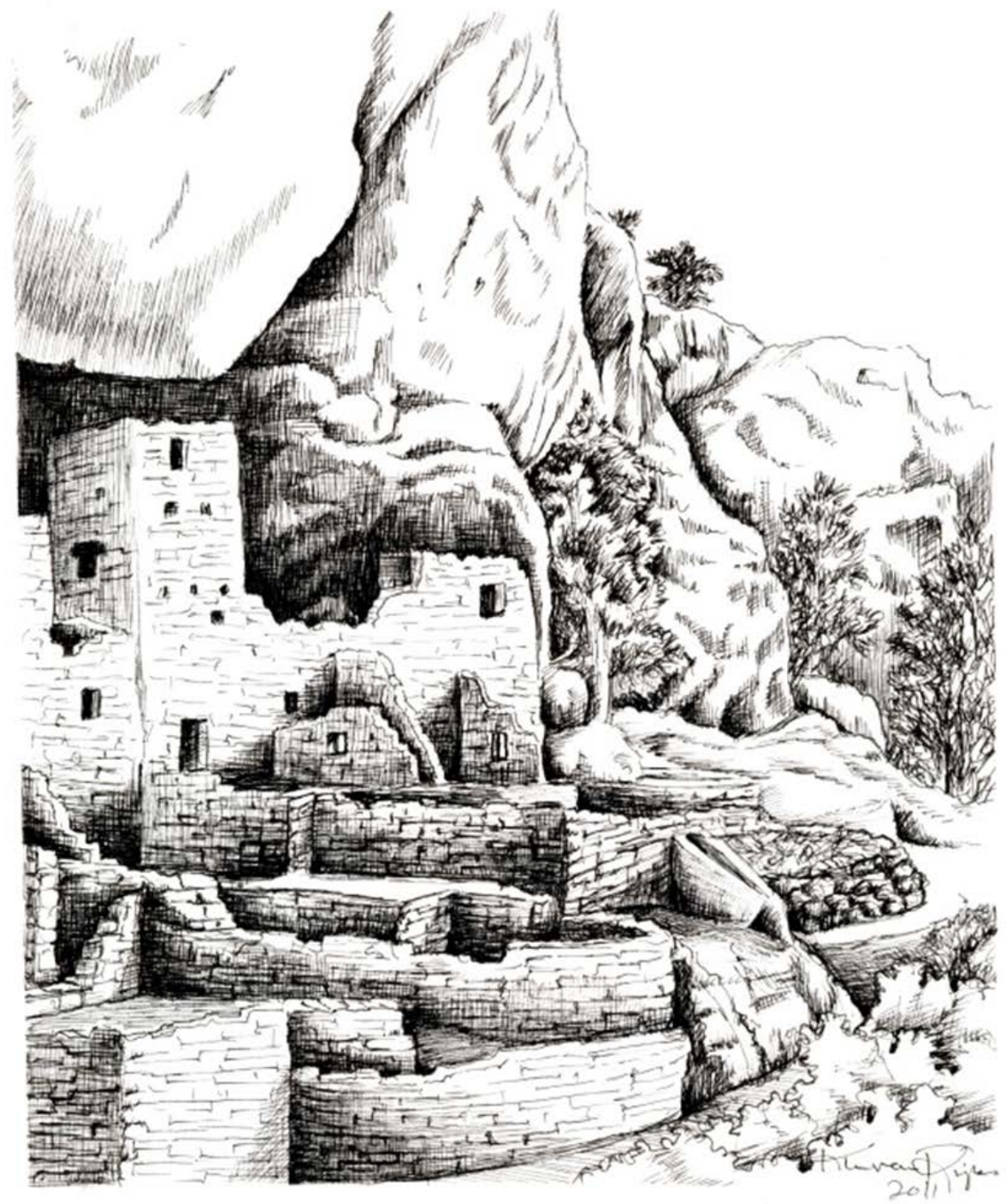

Drawing of Cliff dwellings, Mesa Verde National Park, Colorado (copyright and courtesy of Kimberly Ann van Riper). 


\title{
A Quarter Century of Research on the Colorado Plateau- A Compilation of the Colorado Plateau Biennial Conference Proceedings for 1993-2015
}

\author{
Compiled by Charles van Riper III, ${ }^{1}$ Charles A. Drost,${ }^{1}$ and S. Shane Selleck ${ }^{2}$
}

\section{Executive Summary}

This Open-File Report is a compilation of the work published in the Colorado Plateau Biennial Conference book series over the span of the past nearly quarter century (conferences held between 1991-2011). The primary focus of the conferences has been to work toward integrating new science findings into management of the region's natural and cultural resources. This conference and book series has begun a tradition of cooperation and community, bridging cultural, social, and biophysical research interests and addressing the needs of scientists and land managers working in a complex geographic area. We include here the abstracts for each of the 11 books in the series, as well as links to files with comprehensive literature citations and author listings. The goal of this compilation is to encourage further cooperation and communication on research and management issues of the Colorado Plateau among researchers, land managers, Native American tribes, and the public.

\section{Introduction}

The Colorado Plateau is a region of isolated high mountains, rugged canyons, and high plateaus, encompassing more than 330,000 square kilometers of northern Arizona, southern and eastern Utah, western Colorado, and northwestern New Mexico. It is a region of remarkable geology, extensive wilderness, unique plant and animal communities, rich Native American history, and diverse presentday natural-resource values. Over the past quarter of a century (beginning in 1991) the Colorado Plateau Biennial Conference series has served as a dynamic venue bringing scientists, land managers, students, and the general public together to discuss the physical, biological, and cultural resources of the Colorado Plateau and surrounding Southwest areas. The primary focus of this conference has been to work toward integrating new science findings into management of the region's natural and cultural resources. The conferences began with a focus on National Park Service lands (1st and 2nd conferences) but quickly expanded to take in the Colorado Plateau region as a whole. Participants in the meetings and those who have published in the book series have included researchers from Federal and State governments, universities, and private entities, managers from a wide range of agencies (National Park Service, Bureau of Land Management, U.S. Fish and Wildlife Service, Bureau of Reclamation, U.S. Forest Service, Arizona Game and Fish Department, and many others), and representatives of the region's Native American tribes. These conferences serve the crucial purpose of facilitating intellectual

\footnotetext{
${ }^{1}$ U.S. Geological Survey

${ }^{2}$ Sonoran Desert Research Station, University of Arizona, Tucson, Ariz.
} 
exchange about important resource-management issues, thus creating opportunities for scientists and resource managers to share their experiences and concerns about ongoing management challenges, while trying to balance competing demands on the region's resources. The conferences have also served as a platform for presenting information in a timely fashion, so that new insights can be quickly implemented into resource-management activities. The organizers of the biennial conferences have worked to promote discussion, information sharing, and productive communication among participants, with a focus on enhancing social networks among scientists, students, managers, administrators, tribal representatives, and other attendees.

The conference series has fostered a tradition of cooperation and community within the Colorado Plateau, bridging cultural, social, and biophysical research interests, and addressing the needs of scientists and land managers working in this complex geographic area. As part of the goal of disseminating conference information to wider audiences, a series of books was planned based on papers presented at conferences. This effort debuted in 1993 with an expectation that volumes would be published every other year. Ten books have since been published through 2010, with an 11 th in press. The volumes highlighted papers presented at each biennial conference and have included natural- and cultural-resources research from the late 1980s onwards. Thus, in addition to providing a platform for verbally sharing ideas, conferences have also provided opportunities to publish innovative research findings that have documented the changing state of the integration of research with resource management across the Colorado Plateau.

Like many proceedings series, the Colorado Plateau Biennial Conference books, and the chapters therein, are difficult to find and access through modern indexing and Web-based searches. This Open-File Report is intended to help remedy that situation. It provides a comprehensive compilation of the 11 conferences and the resulting volumes, spanning a 25 -year period. The format and sequence of this compilation follows that of the original book volumes, including, in order, the title of the volume, the editors, and the introduction to that volume. This is followed by the abstracts contained in each book volume. The text from the original books has been reproduced as it was presented with only obvious mistakes corrected and a consistent format applied. Full text access is available for the first five proceedings that were volumes printed by the Government Printing Office (GPO). The last six books of the Colorado Plateau series were published by the University of Arizona (UA) Press. That material is copyrighted; thus, the full text cannot be provided herein. However, UA Press has kindly given permission to allow reproduction of the introductory material and abstracts.

The conferences that are included in this compilation are listed below, along with the citations of the associated proceedings volumes, conference dates, and links to full text where available:

- 1st Biennial Conference - Rowlands, P.G., van Riper, C., III, and Sogge, M.K., eds., 1993, Proceedings of the First Biennial Conference on Research in Colorado Plateau National Parks [July 22-25, 1991]: National Park Service, Transactions and Proceedings Series NPS/NRNAU/NRTP-93/10, http://sbsc.wr.usgs.gov/cprs/news_info/meetings/biennial/proceedings/proceedings.asp.

- 2nd Biennial Conference - van Riper, C., III. 1995, Proceedings of the Second Biennial Conference on Research in Colorado Plateau National Parks [October 25-28, 1993]: National Park Service, Transactions and Proceedings Series NPS/NRNAU/NRTP-95/11, http://sbsc.wr.usgs.gov/cprs/news_info/meetings/biennial/proceedings/proceedings.asp.

- $\quad 3 r d$ Biennial Conference - van Riper, C., III, and Deshler, E.T., eds., 1997, Proceedings of the Third Biennial Conference of Research on the Colorado Plateau [October 17-20, 1995]: National Park Service, Transactions and Proceedings Series NPS/NRNAU/NRTP-97/12, http://sbsc.wr.usgs.gov/cprs/news_info/meetings/biennial/proceedings/proceedings.asp. 
- 4th Biennial Conference — van Riper, C., III, and Stuart, M.A., eds., 1999, Proceedings of the Fourth Biennial Conference of Research on the Colorado Plateau [September 15-18, 1997]: U.S. Geological Survey, Forest and Rangeland Ecosystem Science Center report USGSFRESC/COPL/1999/16, http://sbsc.wr.usgs.gov/cprs/news_info/meetings/biennial/proceedings/proceedings.asp.

- 5th Biennial Conference - van Riper, C., III, Thomas, K.A., and Stuart, M.A., eds., 2001, Proceedings of the Fifth Biennial Conference of Research on the Colorado Plateau [October 1518, 1999]: U.S. Geological Survey, Forest and Rangeland Ecosystem Science Center report USGSFRESC/COPL/2001/24, http://sbsc.wr.usgs.gov/cprs/news_info/meetings/biennial/proceedings/proceedings.asp.

- 6th Biennial Conference-van Riper, C., III, and Cole, K.L., eds., 2004, The Colorado PlateauCultural, biological and physical research [proceedings of the Sixth Biennial Conference of Research on the Colorado Plateau, November 5-8, 2001]: Tucson, University of Arizona Press, 279 p., http://www.uapress.arizona.edu/BOOKS/bid1540.htm.

- 7th Biennial Conference - van Riper, C., III, and Mattson, D.J., eds., 2005, The Colorado Plateau II-Cultural, biological and physical research [proceedings of the Seventh Biennial Conference of Research on the Colorado Plateau, November 5-8, 2003]: Tucson, University of Arizona Press, 448 p., http://www.uapress.arizona.edu/BOOKS/bid1622.htm.

- $\quad$ 8th Biennial Conference-van Riper, C., III, and Sogge, M.K., eds., 2008, The Colorado Plateau III-Integrating research and resources management for effective conservation [proceedings of the Seventh Biennial Conference of Research on the Colorado Plateau, November 7-10, 2005]: Tucson, University of Arizona Press, 432 p. http://www.uapress.arizona.edu/Books/bid1964..

- 9th Biennial Conference - van Riper, C., III, Wakeling, B.W., and Sisk, T.D., eds., 2010, The Colorado Plateau IV - Shaping conservation through science and management [proceedings of the Seventh Biennial Conference of Research on the Colorado Plateau, October 29 through November 1, 2007]: Tucson, University of Arizona Press, 368 p. http://www.uapress.arizona.edu/BOOKS/bid2255.htm.

- 10th Biennial Conference - van Riper, C., III, Villarreal, M.L., van Riper, C.J., and Johnson, M.J., eds., 2012, The Colorado Plateau V-Research, environmental planning, and management for collaborative conservation [proceedings of the Seventh Biennial Conference of Research on the Colorado Plateau, October 5-8, 2009]: Tucson, University of Arizona Press, 346 p. http://www.uapress.arizona.edu/BOOKS/bid2386.htm.

- 11th Biennial Conference-Huenneke, L.F., van Riper, C., III, and Hays-Gilpin, K.A., eds., in press, The Colorado Plateau VI-Cultural and natural resource management on the Colorado Plateau-Science and management at the landscape scale [proceedings of the Seventh Biennial Conference of Research on the Colorado Plateau, October 24-27, 2011]: Tucson, University of Arizona Press.

In summary, our goal with this report is to make the articles and information from the Colorado Plateau book series more accessible to Web indexing services and hence more readily available. In this manner, scientists, land managers, and all of those interested in and concerned about the natural and cultural resources of the region can use the information from this series to better learn from the past, evaluate how best to respond to present issues, and make better informed decisions for the future. It is our hope that this document will serve as an important source of scientific information about the people, landscape, and natural communities of the Colorado Plateau. Just as importantly, it is also our hope that this compilation will encourage further cooperation and communication among researchers, land managers, Native American tribes, and the public across this remarkable region of North America. 


\section{Literature Cited and Author List}

Rather than duplicate the references from all 186 chapters of the 11 books in the Colorado Plateau series, we compiled all of the cited references together, removed duplicates, and placed the references in a downloadable comma separated values (.csv) file available at the following link: http://sbsc.wr.usgs.gov/cprs/news_info/meetings/biennial/proceedings/proceedings.asp. The reference file contains columns for author(s), date, title, and source. It will open directly in spreadsheet software or can easily be imported into a database program. It can also be opened in any word processing program (you may need to change the file type to "all files" when you first open it). The bibliography does not contain a separate keywords field, but it can be searched for any author, title, and (or) source words in most programs that you would use to view it. With the addition of this comprehensive reference list, the present compilation also represents a substantial bibliography of natural and cultural resources research and management for the Colorado Plateau region. Readers will find that there are some references to unpublished documents in this compilation, and if interested, they can contact the authors of the associated chapter to request how best to access the unpublished material.

A comprehensive list of the authors that have contributed chapters to one or more of the 11 Colorado Plateau Biennial Conference proceedings volumes is available as a .csv file at http://sbsc.wr.usgs.gov/cprs/news_info/meetings/biennial/proceedings/proceedings.asp. Authors are listed alphabetically, along with the volume (or volumes) to which they contributed and their affiliation. For authors that contributed to more than one volume of the proceedings series, the appendix list shows the affiliation listed for the most recent contribution. 


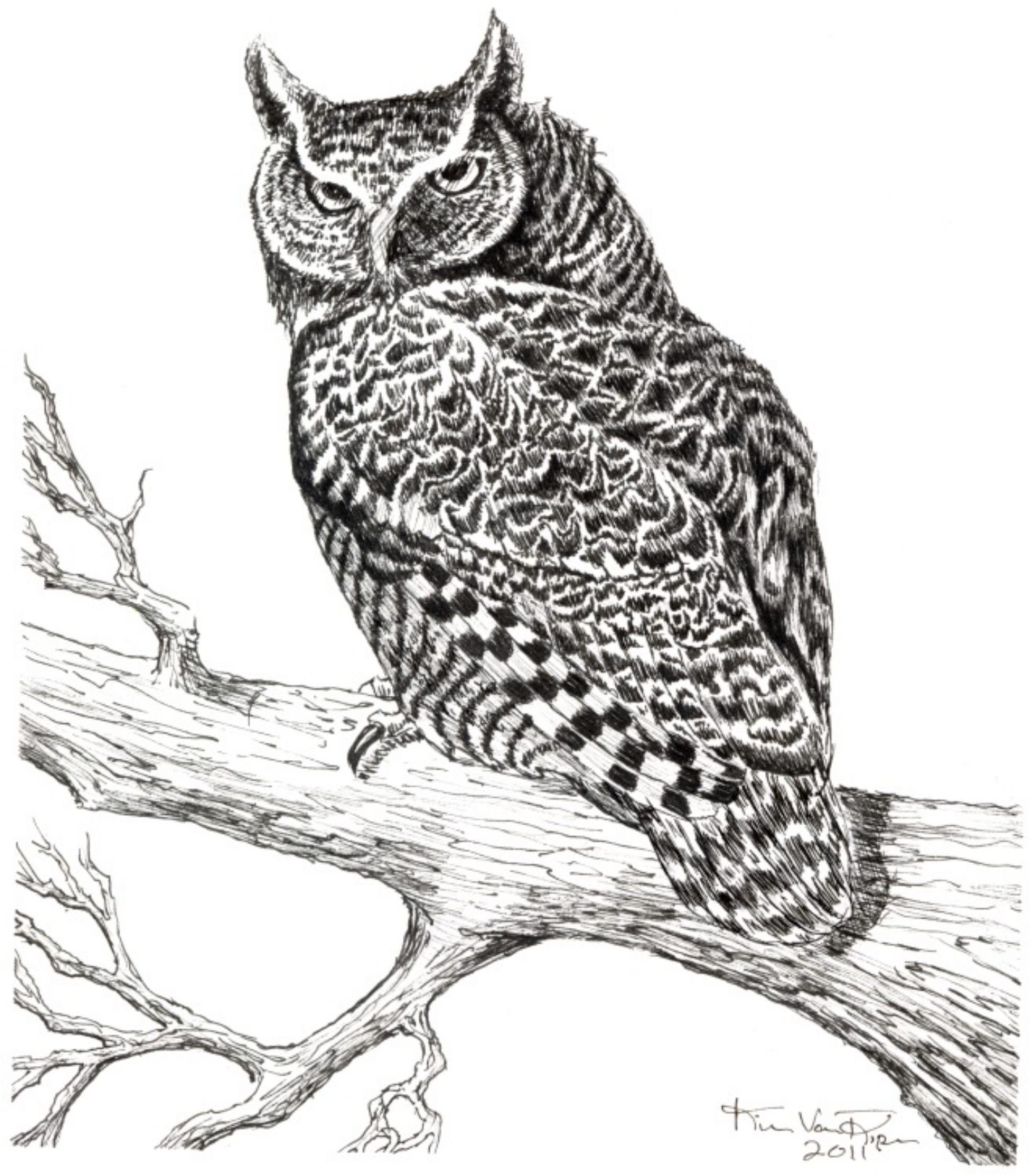

Drawing of great horned owl, Bubo virginianus (copyright and courtesy of Kimberly Ann van Riper). 


\title{
Proceedings of the First Biennial Conference on Research in Colorado Plateau National Parks
}

\author{
Edited by Peter G. Rowlands, Charles van Riper III, and Mark K. Sogge
}

The 19 papers in this volume were selected from the 46 presentations given at the First Biennial Conference on Research in Colorado Plateau National Parks. The overall theme for this meeting was research, inventory, and monitoring in National Park Service units on the Colorado Plateau. The conference, held in Flagstaff, Arizona, on 22-25 July 1991, was sponsored by the National Park Service Cooperative Park Studies Unit, Northern Arizona University, and the Petrified Forest, Zion, and Grand Canyon natural history associations.

This volume highlights research and resource management efforts to inventory and monitor natural and cultural resources in the national parks of the Colorado Plateau. Many of the inventory and monitoring protocols and techniques used in one park unit should be applicable to other national park units throughout the Colorado Plateau and possibly in other areas with similar habitats. The papers in this book naturally divide themselves into four major sections: biological resources, cultural resources, physical resource management, and GIS and information management. The majority of the papers (10 of 19) deal with biological resources, and 7 of these are concerned with inventory and monitoring of animals. Valdez and Williams and Valdez, Masslich, and Crist describe the ichthyofauna of the Colorado River in the Grand Canyon reach as well as methodologies associated with inventorying the endangered humpback chub (Gila cypha). The relation between an exotic game fish-rainbow trout (Oncorhynchus mykiss) - and wintering bald eagles (Haliaeetus leucocephalus) in Grand Canyon is the subject of a paper by Leibfried and Montgomery. Richard Glinski imparts valuable information on monitoring protocols for peregrine falcons (Falco peregrinus), another endangered species.

One of the papers deals with plant-herbivore relations. Gaud, Allred, and States present the results of their investigations on tree selection and utilization of ponderosa pine (Pinus ponderosa) by Abert's squirrels (Sciurus aberti): The larger the tree, the more likely it will be a feed-tree more than once.

Bighorn sheep (Ovis canadensis) is the subject in two papers. Charles Douglas investigated the relations between weather and climatic patterns and survivorship of bighorn lambs. Cunningham and Hanna have written a paper that explores the possible effects of realigning U.S. Highway 93 in the vicinity of Hoover Dam (in Arizona and Nevada) on the local bighorn sheep population.

Botanical resources are also represented by three diverse papers. Joyce Maschinski documents various strategies employed in the conservation of sentry milkvetch (Astragalus cremnophylax var. cremnophylax), an endangered limestone-endemic from Grand Canyon National Park. The late Pleistocene - early Holocene vegetation of Arches National Park is described in a paper by Saxon Sharpe-a documentary and analysis of packrat (Neotoma spp.) middens. Bock and Bock assert that cattle act as a keystone species affecting semiarid grassland vegetation on the Colorado Plateau.

The adverse effects of livestock on archaeological resources are both measurable and substantive according to information presented by Osborn and Hartley. Phil Geib and Geib and Lyneis uncovered archaeological evidence that Anasazi (Fremont) occupation of Glen Canyon was earlier than previously supposed. Furthermore, distinctions among types of Fremont pottery could be discerned on the basis of igneous rock types used as temper. 
Physical resources are represented by three papers in three diverse fields. The effects of 10 years of human presence on Colorado River beaches in the Grand Canyon Reach are documented by Beus and Lojko. Avery and Helmke describe the hydraulic setting and dynamics of Montezuma Well, a large water-filled sink hole in Montezuma Castle National Monument. Linda Mazzu's article on the monitoring of aircraft at Grand Canyon National Park and its use as a tool in managing for natural quiet is perhaps the most unusual paper in this collection in that it deals with issues (natural quiet and visitor experience) that are rarely studied. A report on the findings of the conference's symposium on air quality, written by Roger Clark of the Grand Canyon Trust, rounds out this section of the proceedings.

Geographic information systems and information management, the last section of the proceedings, is represented by two papers. Christopherson, Ball, and Guertin describe how the choice of a digital elevation model in a GIS application may affect the outcome of a viewshed analysis, a common technique used by land-use planners in various agencies. Finally, Fraire and Stohlgren summarize the results of the evaluation of existing inventory and monitoring data bases in the Colorado Plateau park units.

This publication is a direct result of the efforts of numerous agencies and individuals. In the planning stages, Northern Arizona University conference personnel provided advice and assistance in structuring the conference. Conference registration was handled by M. Rasmussen. Northern Arizona University graduate students, directed by Elena T. Deshler, assisted with logistics at the meeting, operated slide projectors, and provided general assistance with the paper sessions. Each paper represents original research and has been peer reviewed by at least two reviewers in that particular research discipline. We thank J. Reese for editorial scrutiny of the book and the many reviewers who unselfishly devoted their time and efforts to improving each chapter. Financial support for this publication was provided with matching funds from the Natural History Associations of Zion National Park, Glen Canyon National Recreation Area, Petrified Forest National Park, and the Washington Office Servicewide Publications Program of the National Park Service. We thank the Western, Southwestern, and Rocky Mountain regional offices of the National Park Service and the faculty and staff of Northern Arizona University for their support throughout the development of these proceedings. We are also deeply indebted to all the talented individuals who gave their valuable time in seeing this product through the publication stage.

We feel that this book, like the products of other symposia focusing on particular problems, should help redirect and improve the quantity and quality of research and resource management action in an area of presently active interest within the National Park Service.

\section{Abstracts}

ICHTHYOFAUNA OF THE COLORADO AND GREEN RIVERS IN CANYONLANDS NATIONAL PARK, UTAH

Richard A. Valdez and Robert D. Williams

Thirty-one species of fish were found in the Colorado and Green rivers in and adjacent to Canyonlands National Park during 1985-88 in the first intensive ichthyofaunal survey of the area. We found 8 native species (5\% of total number) and 23 nonnative species (95\%). The four species of endemic mainstem fishes that are federally classified as endangered were present-Colorado squawfish (Ptychocheilus lucius), humpback chub (Gila cypha), bonytail (G. elegans), and razorback sucker (Xyrauchen texanus). Numerous age-0 (young-of-year) Colorado squawfish were found as were small numbers of juveniles and adults. A reproducing population of humpback chub was confirmed in Cataract Canyon, and six suspected bonytail were found. Only one adult razorback sucker was captured. Endemic roundtail chub (G. robusta) and flannelmouth sucker (Catostomus latipinnis), as well as native 
bluehead sucker (C. discobolus) and speckled dace (Rhinichthys osculus), were also present in low numbers. The most common species in backwaters and shorelines were nonnative red shiners (Cyprinella lutrensis), sand shiners (Notropis stramineus), and fathead minnows (Pimephales promelas), while channel catfish (Ictalurus punctatus) and common carp (Cyprinus carpio) were the dominant main channel species.

Keywords: Bonytail, Canyonlands National Park, Cataract Canyon, Colorado River endangered fish, Colorado River ichthyofauna, Colorado squawfish, humpback chub, razorback sucker.

\section{FIELD METHODS FOR STUDYING THE COLORADO RIVER FISHES IN GRAND CANYON} NATIONAL PARK

\section{Richard A. Valdez, William J. Masslich, Larry Crist, and William C. Leibfried}

Field investigations were initiated in October 1990 to study the ichthyofauna of the Colorado River in Grand Canyon National Park with emphasis on the life history and ecology of the endangered humpback chub (Gila cypha). These investigations were part of the environmental studies to evaluate the operation of Glen Canyon Dam. Small maneuverable research boats, modified fish sampling methods, and radiotelemetry were evaluated for continued use in this fishery investigation. Small research boats increased access from established base camps to sample sites, both up- and downstream, providing more thorough sampling coverage. These small boats required skilled handlers and were used for electrofishing, to set and retrieve fish sampling gears, and to recontact radio-tagged fish. Electrofishing, gill and trammel nets, hoop nets, minnow traps, and seines were adapted for use in riverine and whitewater habitats to assess relative abundance, distribution, and habitat use of fishes of all ages. Radiotelemetry was used to monitor movement and habitat of adult humpback chub, although signal strength was limited by water depth, specific conductance, and canyon geologic features. We demonstrated that small research boats, modified fish sampling methods, and radiotelemetry are effective in whitewater regions, such as the Colorado River in Grand Canyon, as aids to better understand the ichthyofauna of these little-known regions.

Keywords: Colorado River fishes, electrofishing, fish sampling gears, Grand Canyon National Park, humpback chub, research boats.

\section{REGULATED FLOWS, TROUT SPAWNING, AND ABUNDANCE OF BALD EAGLES ON THE} COLORADO RIVER, GRAND CANYON NATIONAL PARK

\section{William C. Leibfried and W. Linn Montgomery}

Rainbow trout (Oncorhynchus mykiss) moved into and spawned in Nankoweap Creek, a tributary of the Colorado River in Grand Canyon, during February and March 1990. Abundance of spawning trout in the lower $600 \mathrm{~m}$ of the creek peaked at 1,565 fish. Bald eagle (Haliaeetus leucocephalus) abundance peaked at 26 during the same period. Movements of spawning trout into Nankoweap Creek were not correlated with river flows between 5,000 and 20,000 cubic feet per second (cfs) but were positively correlated with water temperatures in the creek. The number of trout tagged in the main channel and recaptured in Nankoweap Creek was positively correlated with higher minimum daily flows $\left(\mathrm{r}^{2}=0.41, \mathrm{P}=0.003, \mathrm{df}=17\right)$ in the river. Trout were able to enter Nankoweap Creek at all flows observed in the river during the study.

Keywords: Bald eagle, migration, predation, rainbow trout, regulated flow, reproduction.

PEREGRINE FALCON RECOVERY IN THE SOUTHWEST: THE ADMINISTRATIVE NECESSITY FOR A SURVEY PROTOCOL AND THE ECOLOGICAL IMPORTANCE OF THE GRAND CANYON 


\section{Richard L. Glinski}

Peregrine falcons (Falco peregrinus), although listed as an endangered species, bred at 179 sites in Arizona in 1992. The population exceeds the 1984 recovery goal of 46 breeding sites in Arizona. Of the 179 known sites, 71 are in the Grand Canyon National Park. Ecologically, the park provides ideal peregrine nesting habitat. When combined with other similar habitats of dramatic topographic relief, the Colorado Plateau probably provides the recruitment for population increases throughout the Southwest. Locating peregrine falcon breeding sites and monitoring reproduction are the main recovery actions for documenting population expansion-the essential element for delisting. A survey protocol used since 1987 throughout Arizona to document the occurrence of breeding peregrines was used in the Grand Canyon in 1988 and 1989. The protocol was not in place at the onset of surveys in 1975, and the pattern of breeding site reoccupancy is unavailable to assist in identifying and managing the ecological needs of nesting peregrines in Arizona and the Southwest.

Keywords: Arizona, canyon, Falco peregrinus, Grand Canyon, nesting, peregrine falcon.

\section{TREE SELECTION BY TASSEL-EARED SQUIRRELS OF THE PONDEROSA PINE FORESTS OF THE COLORADO PLATEAU}

\section{William S. Gaud, W. Sylvester Allred and Jack S. States}

Three subspecies of tassel-eared squirrels (Sciurus aberti) are endemic to the ponderosa pine (Pinus ponderosa) forests of the Colorado Plateau, including several national parks and monuments. In foraging for inner bark, squirrels have removed as many as 1,078 shoots from a single ponderosa pine tree in one 6-month period. Most trees, however, escape such herbivory entirely. A stand contains relatively few feed trees among all trees present. The larger the tree, however, the more likely it will be a feed tree more than once. In spite of the opportunity to return time after time to the same favorite trees, only one-fourth of all the feed trees could be so classified in more than one census period. The variation in the number of shoots removed in any census period was largely explained by the availability of pine seed.

Keywords: Feed tree, Pinus ponderosa, plant-herbivore interaction, ponderosa pine, Sciurus aberti, squirrel.

\section{MANAGEMENT MODEL FOR PREDICTING FALL LAMB:EWE RATIOS IN DESERT BIGHORN SHEEP, CANYONLANDS NATIONAL PARK, UTAH \\ Charles L. Douglas}

The status of the bighorn sheep (Ovis canadensis) herd in Canyonlands National Park is of concern to managers. The Island-in-the-Sky herd is harvested for transplanting, and herd recovery following removals in 1982-85 has been below expectations. Weather and survey data for 1976-85 were used to develop a predictive model for lamb:ewe ratios that would be expected on fall surveys; data for 1986-89 were used to test the model. Three predictive variables-maximum temperatures in May and precipitation in April the year of the survey and precipitation from January through March 2 years before bighorn surveys-had strong, significant relations to lamb counts. These variables were correlated with each other; therefore, the data were analyzed by principal components analysis. The best predictive model was developed by regressing the first principal component with lamb:ewe ratios for the 10 -year period. The model was significant $(\mathrm{P}=0.001)$ and explained $76 \%$ of the variation in lamb:ewe ratios for 1976-85 $(\mathrm{SE}=9)$. The selected variables were important in vegetative growth-biomass and forage quality apparently control bighorn population dynamics in Canyonlands National Park. Actual lamb:ewe ratios averaged eight lambs less than the predicted ratios for 1986-89. Maximum temperature in May was in the upper quartile of its range in 1988 and 1989 and may have negatively 
influenced lamb survival. Removals of animals for transplants in 1982-85 were biased toward ewes and may have affected age structure of ewes, resulting in fewer lambs being produced than would be expected.

Keywords: Bighorn sheep, Canyonlands National Park, ewe, lamb, Ovis canadensis, ratios.

POSSIBLE EFFECTS OF THE REALIGNMENT OF U.S. HIGHWAY 93 ON MOVEMENTS OF DESERT BIGHORNS IN THE BLACK CANYON AREA

Stanley C. Cunningham, Layne Hanna, and Joseph Sacco

We collared 49 desert bighorns (Ovis canadensis nelsoni) adjacent to Hoover Dam in the Black Mountains of Arizona. We monitored their movements for up to 2 years to determine areas of importance, potential movement corridors, and reactions to U.S. Highway 93. Three separate ewe groups used distinct lambing and watering areas. One of the ewe groups will be most affected by realignment of U.S. Highway 93 because the ewes routinely cross Highway 93 and because their home ranges will be bisected by any one of the three considered highway alignments. Only the Promontory Point alignment would bisect home ranges of ewes in the other groups. We believe that the Gold Strike alignment would cause the most harm to local bighorns. Vehicle speed will probably increase on the finished highway on any of the alignments chosen, and the increased speed will increase bighorn deaths. Keywords: Arizona, bighorn sheep, Black Mountains, habitat fragmentation, highway, Ovis canadensis, vehicle collision.

\section{INTEGRATED CONSERVATION STRATEGIES FOR RECOVERY OF SENTRY MILKVETCH AT THE SOUTH RIM OF GRAND CANYON NATIONAL PARK Joyce Maschinski}

The endangered plant, sentry milkvetch (Astragalus cremnophylax var. cremnophylax), is known only from the south rim of Grand Canyon. To mitigate declines in the population, personnel from the U.S. Fish and Wildlife Service, Grand Canyon National Park, and The Arboretum at Flagstaff have used several strategies. These include monitoring mortality and natality in the population, protecting the population by erecting a fence, surveying for new populations, and conducting basic research and reintroduction studies. Greenhouse germination studies indicated that an average of $49 \%$ germination could be expected under high watering conditions. Transplanted seedlings had greatest survival in soils of high limestone composition. Using this information from greenhouse studies, 196 seeds were reintroduced into four different microsite types at Maricopa Point in 1990. Despite the good rains received at Maricopa Point in summer 1990, seed germination and survival in experimental microsites was poor. Although $10 \%$ of seeds germinated, only $1 \%$ of the seedlings successfully survived until fall, and $0.5 \%$ of the seeds survived winter 1990-91. Thus, field germination was below expected. Ongoing tests of natural germination may give insights into requirements for natural establishment and reasons why the seedling establishment failed in the chosen microsites.

Keywords: Astragalus, conservation, endangered plants, endangered species, Grand Canyon National Park, reintroduction, sentry milkvetch.

\section{LATE-WISCONSIN AND HOLOCENE VEGETATION IN ARCHES NATIONAL PARK, UTAH Saxon E. Sharpe \\ Eleven Neotoma spp. (packrat) middens, dating from approximately 20,000 B.P. to the present, were collected from a single alcove site at 1,317 m elevation in Arches National Park, Grand County, Utah. Macroscopic plant remains from these late-Wisconsin and Holocene middens generally support other records of elevational displacements for plants on the Colorado Plateau. Results indicate that}


vegetation more mesophytic than present dominated the Bison Alcove area between 20,000 and 12,500 B.P. Pinus flexilis (limber pine) and Pseudotsuga menziesii (Douglas-fir), no longer growing in the park, predominate the fossil assemblages. A minimum Pleistocene displacement of $513 \mathrm{~m}$ for Pinus flexilis and $208 \mathrm{~m}$ for Pseudotsuga menziesii is indicated. Modern vegetation was in place at this location sometime before 2,660 B.P.

Keywords: Arches National Park, Holocene vegetation, late-Wisconsin vegetation, packrat midden, paleoecology, Pleistocene vegetation.

\section{EFFECTS OF LONG-TERM LIVESTOCK EXCLUSION IN A SEMIARID GRASSLAND Carl E. Bock and Jane H. Bock}

Southwestern semiarid grasslands and those of the Colorado Plateau developed in the absence of large herds of native ungulates. The Appleton-Whittell Research Ranch is a 3,160-ha National Audubon Society sanctuary in southeastern Arizona where livestock have been excluded since 1968. By 1990, canopy cover of upland perennial grasses averaged $61 \%$ on the sanctuary, compared with $41 \%$ on adjacent cattle ranches. Among the 10 most common species, the tallest bunchgrasses (Bothriochloa barbinodis, Bouteloua curtipendula, and Eragrostis intermedia) responded most positively to release from grazing, while two short, stoloniferous grasses (Bouteloua eriopoda and Hilaria belangeri) were more abundant on grazed lands.

In general, common animals on the exclosure have been those requiring cover, while species preferring open habitat and bare ground dominated grazed areas. Peak fall densities of grasshoppers were over 3 times higher on grazed land. The bunchgrass lizard (Sceloporus scalaris) was the most abundant reptile on the sanctuary, but it was virtually absent from adjacent ranches. Cottonrats (Sigmodon spp.), harvest mice (Reithrodontomys megalotis), and hispid pocket mice (Perognathus hispidus) were the common rodents in ungrazed habitat, whereas deer mice (Peromyscus spp.) and kangaroo rats (Dipodomys merriami) predominated in grazed areas. Montezuma quail (Cyrtonyx montezumae), Cassin's sparrows (Aimophila cassinii), Botteri's sparrows (A. botterii), and grasshopper sparrows (Ammodramus savannarum) were common breeding birds on the sanctuary. The most abundant nesting birds on grazed lands were scaled quail (Callipepla squamata), horned larks (Eremophila alpestris), and lark sparrows (Chondestes grammacus).

We conclude that livestock, functioning as keystone species in grasslands of southeastern Arizona, can determine which components of the native flora and fauna persist or increase and which decline or disappear.

Keywords: Arizona, birds, grasshoppers, grassland, grazing, livestock, rodents.

\section{ADVERSE EFFECTS OF DOMESTIC LIVESTOCK GRAZING ON THE ARCHAEOLOGICAL RESOURCES OF CAPITOL REEF NATIONAL PARK, UTAH}

\section{Alan J. Osborn and Ralph J. Hanley}

The effect of livestock grazing on archaeological resources in Capitol Reef National Park was evaluated by examining 8 existing prehistoric sites and by establishing 13 experimental artifact plots. Five of the prehistoric sites were rock-shelters, first recorded in 1958. Qualitative reassessments of these sites in 1985 revealed substantial effects of cattle and human vandalism. The effects of grazing were quantitatively assessed by establishing 12 2-m x 2-m plots and $11-\mathrm{m} \times 1-\mathrm{m}$ control plot with manufactured stone flakes, tools, and ceramic fragments. Experimental plots were established in fall 1985 and monitored after a 10-month period. Factors monitored included differential breakage and damage, visibility, and displacement. Both lithic and ceramic artifacts are damaged by livestock activity, but ceramic artifacts are more severely affected. 
Keywords: Animal trampling, archaeological remains, Capitol Reef National Park, ceramic artifacts, grazing.

\section{NEW EVIDENCE FOR THE ANTIQUITY OF FREMONT OCCUPATION IN GLEN CANYON,} SOUTH-CENTRAL UTAH

Phil R. Geib

Portions of the Glen Canyon National Recreation Area north of the Colorado River, especially the Escalante River basin, contain distinctive material remains interpreted as evidence of a Fremont occupation. Though never directly dated, this occupation was thought to have been contemporaneous with an A.D. 1050-1250 Anasazi occupation of Glen Canyon. To determine the actual age of the Fremont remains, 13 maize samples from five excavated sites of the Escalante River basin were radiocarbon dated. One date with a calibrated 1 sigma age range of 400-200 B.C. is substantially earlier than the rest and provides the current earliest direct date on maize from this portion of Utah. Eleven overlapping dates spanning the centuries circa A.D. 200-900 provide a basis for arguing that the Fremont occupation of Glen Canyon was earlier than previously supposed. The one date in the A.D. 1000 's is associated with typical Anasazi remains to the near exclusion of Fremont material.

Keywords: Chronometrics, Fremont, Glen Canyon, maize, Utah prehistory.

\section{SOURCES OF IGNEOUS TEMPER FOR FREMONT CERAMICS OF SOUTH-CENTRAL UTAH} Phil R. Geib and Margaret M. Lyneis

To delineate production zones for Fremont pottery of south-central Utah, we identified the geologic sources of the igneous rock used to temper the pottery produced in the region. Igneous inclusions were first classified into a series of temper types based on mineral and textural differences perceived under low-power (x30) magnification. The types were then visually correlated with igneous rock samples collected from various geologic formations of south-central Utah. Subsequent petrographic analysis confirmed these correlations and allowed us to describe the mineralogy of the temper types. We provide an initial basis for differentiating general production zones of Fremont pottery from south central Utah, and indicate the need for rethinking the existing classification of Fremont pottery.

Keywords: Ceramic production, ceramics, Fremont, Utah prehistory.

\section{LONG-TERM EFFECTS OF HUMANS ON BEACHES AT SELECTED COLORADO RIVER CAMPSITES IN GRAND CANYON NATIONAL PARK}

Stanley S. Beus and Frank B. Lojko

Colorado River campsite beaches in Grand Canyon were monitored for human effects more than 10 years (1980-90). Observations included quantitative measurement of human litter, charcoal particles, and light reflectance from beach sands. Analysis of data from 21 selected campsite beaches and one noncamping beach used for control indicated the following:

1. heavily used beaches in Glen Canyon are and were significantly more degraded than those in Grand Canyon where camping is more carefully regulated;

2. litter and charcoal particles were essentially eliminated from all beaches by the high waterflows (spills) of 1983;

3. since 1983, a gradual increase in human contamination has occurred on most beaches monitored (90\%);

4. contamination by charcoal is more significant than human litter on most beaches studied; 
5. Grand Canyon beaches accessible only by river are generally less contaminated than those approachable by hikers, anglers, and river parties; and

6. the policies governing campsite procedures initiated by the National Park Service and followed by river recreationists seem to have substantially reduced human contamination of campsite beaches in Grand Canyon.

Keywords: Beaches, campsites, Colorado River, human contamination, recreation.

\section{MONTEZUMA WELL: A DYNAMIC HYDROLOGIC SYSTEM}

\section{Charles C. Avery and Martin Helmke}

We investigated the hydrology of Montezuma Well, Arizona, to determine if the system was homeostatic (as previously implied) or dynamic. The discharge records for the past 6 water years show variation in outflow and a dynamic system. A seasonal trend was evident where values are slightly greater in winter and spring months and slightly lower in late summer and fall months. The water level fluctuations have a coefficient of variation of $32.5 \%$, and the measured discharge fluctuates both on an annual and a daily scale. While seasonal variation might contribute to the erratic nature of the observed discharge at the Montezuma Well gage, we were unable to document a causative mechanism without intensive study.

Keywords: Arizona, hydrologic system, hydrology, Montezuma Well, water balance.

\section{AIRCRAFT MONITORING METHODS AT GRAND CANYON NATIONAL PARK: AN EVALUATION \\ Linda C. Mazzu}

Grand Canyon has the most regulated airspace in the National Park system. With an air traffic volume of about 8,000 flights per month in the summer season, it became necessary to develop a monitoring program to provide National Park Service managers with data on the use in different sections over the park. Seven locations throughout the park were selected where flight corridor traffic near flight-free zones could be tabulated. The number of sampling hours per location was determined using a running mean. Three observation sessions show that air traffic numbers are high (up to 32 aircraft per hour) in some locations, but compliance with the regulation exceeded $98 \%$. Survey results and results of acoustic and sociological research will be used to determine when changes to the regulations are needed to protect natural quiet.

Keywords: Aircraft, airspace, air tours, monitoring, natural quiet, overflights.

\section{AIR QUALITY ON THE COLORADO PLATEAU: PANEL DISCUSSION SYNOPSIS Roger Clark \\ Air Quality Panelists:}

John C. Freemuth (Department of Political Science, Boise State University)

Ken Luckow (U.S. Forest Service)

Deborah Mangis (National Park Service, Air Quality Division)

C. V. Mathai (Arizona Public Service)

Linda Mazzu (Grand Canyon National Park)

Five air quality experts participated in a panel discussion about the future of air quality on the Colorado Plateau. The synopsis of their comments is preceded by a historical interpretation of legislative and regulatory actions that have been applied to protecting visibility in national parks and wilderness areas, with particular emphasis on actions to control emissions at the Navajo Generating Station near Grand Canyon National Park. The synopsis presents priorities for visibility and ecological 
research, implementing provisions of the Clean Air Act, funding, public education, and cooperation. The panelists also identified political and legal challenges to progress in protecting air quality on the Colorado Plateau, but were unanimous in their optimism about prospects for the future.

Keywords: Air quality, Clean Air Act, national parks, regulations, visibility, wilderness.

\section{COMPARISON OF INTERPOLATION ALGORITHMS FOR DIGITAL ELEVATION MODEL GENERATION AND SUBSEQUENT VIEWSHED ANALYSIS}

Gary L. Christopherson, D. Phillip Guertin, Michael R. Kunzmann, Kenneth L. Kvamme and Thomas Potter

Models created by geographic information systems are becoming increasingly important tools for the management of natural and cultural resources. These models, however, are only as good as the algorithms used to create them. We examine the effects of four different algorithms on digital elevation models (DEM's) and on the viewshed analyses derived from these models. Each algorithm will create a unique DEM from the same data set; each algorithm has weak points; and the choice of algorithms has important consequences for the accuracy of both the resulting DEM and the viewshed based on the chosen model. Each interpolation algorithm, given identical data sets, will create a unique DEM, and there are often important differences between the different DEM's. We can infer from these differences that there will never be a one-to-one correspondence between DEM's and the real world as long as interpolation algorithms are used. Differences in DEM's will affect derived themes like viewshed analysis - sometimes significantly.

Keywords: Algorithm, digital elevation model, error evaluation, geographic information systems, viewshed analysis.

\section{EVALUATING BASELINE BIOLOGICAL DATA BASES IN NATIONAL PARK UNITS IN} ARIZONA

\section{Elena T. Deshler, Thomas J. Stohlgren and Mark K. Sogge}

As part of the National Park Service Inventory and Monitoring Project (Phase I), Biological Inventory Status data bases were created that were used in assessing the completeness of information on vascular plants, amphibians, reptiles, birds, and mammals for 12 national park units in Arizona. We evaluated the taxonomic, geographic, and ecologic completeness of existing data for each biological group. Information on birds was the most complete, followed by plants and mammals. Data on reptiles and amphibians were the least complete. Database structure and content in each park unit and among park units lacked standardization. Various data management practices made it difficult to readily access resource information. Lack of ready access emphasizes the importance of standardizing the methods used to record, catalog, and store baseline data among the various National Park Service units and across regional boundaries. The Colorado Plateau National Park Service units could improve future inventory programs by standardizing their methods of data collection. Keywords: Arizona park baseline, fauna, flora, inventory, monitoring. 


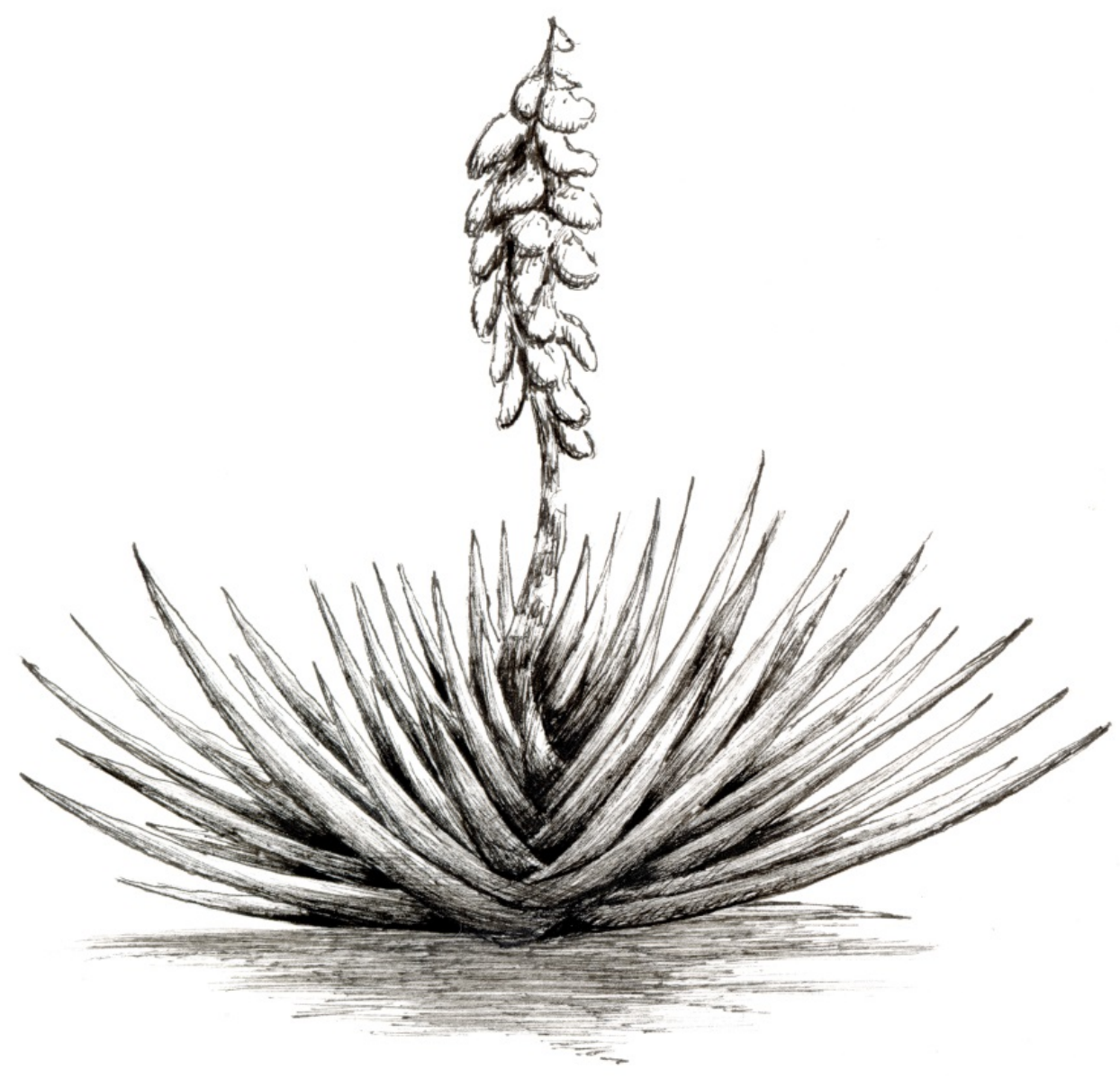

Drawing of banana yucca, Yucca baccata (copyright and courtesy of Kimberly Ann van Riper). 


\title{
Proceedings of the Second Biennial Conference on Research in Colorado Plateau National Parks
}

\author{
Edited by Charles van Riper III
}

On 25-28 October 1993 in Flagstaff, Arizona, the National Biological Service Colorado Plateau Research Station (formerly National Park Service Cooperative Park Studies Unit) and Northern Arizona University hosted the Second Biennial Conference of Research on the Colorado Plateau. The conference theme focused on research, inventory, and monitoring on federal, state, and private lands in the Colorado Plateau biogeographic province.

This is the second volume (see Rowlands et al. 1993) of a planned series of Colorado Plateau Research Station proceedings that highlights research and resource management efforts related to physical, cultural, and natural resources within the Colorado Plateau biogeographic province. The 16 papers in this volume were selected from 68 posters and research papers presented at the Second Biennial Conference. Each paper represents original research and has been reviewed anonymously by three peers in that particular research discipline. This volume of proceedings, like the products of other symposia centered around particular themes, will focus attention on some of the salient research being conducted within the Colorado Plateau. I expect this information to stimulate additional support for work on resources of the Colorado Plateau. If the expectation is achieved, the organizational and editorial efforts of the past several years will have paid dividends.

The papers naturally divide themselves into physical resources, cultural resources, and biological resources.

\section{Physical Resources}

Hanging gardens are one unique aspect of the Colorado Plateau. May, Fowler, and Stanton describe the geomorphology and community structure of hanging gardens and point out that these gardens occur over sections of the plateau because of unique geologic and hydrologic features. The hanging gardens in each national park on the Colorado Plateau are identified, and a brief classification is provided.

The second paper, by Netoff, Cooper, and Shroba, addresses weathering pits (also known as tanks, caldrons, huecos, dew holes, potholes, water pockets, and tinajas) in sandstone substrate-another unique facet of the Colorado Plateau. The authors discuss weathering pits in the Glen Canyon National Recreation Area, specifically the series of pits near Cookie Jar Butte. The paper focuses on causes of formation of the pits.

Brown and Davila provide, in the next paper, an insight into how a large-scale mapping project can be beneficial to land managers on the Colorado Plateau. The authors mapped geologic features of Great Basin National Park. The integration of scientific expertise with management needs can benefit all involved parties.

In the final paper of the first section, Dexter, Cluer, and Manone report on the development of a method to monitor sandbar stability along rivers. This research was part of the multimillion dollar Bureau of Reclamation-Glen Canyon Environmental Studies research effort to examine the potential effects of fluctuating flows from Glen Canyon Dam on the down-river resources of Grand Canyon National Park. 


\section{Cultural Resources}

The four papers in this section were chosen to represent a cross section of cultural and social research being carried out over the Colorado Plateau. The topics presented span a time interval from the archaic (9000 BP) through the Fremont culture (1000 BP) to historical fires in Mesa Verde and a 1993 telephone survey of Arizona residents on perceptions about preservation of Grand Canyon National Park. This section provides the reader with a representative spectrum of research and management alternatives that cultural resource managers can utilize to better know, protect, and preserve archeological, cultural, and social resources over the Colorado Plateau.

One of the continuing controversies that exists on archaic occupation of the Colorado Plateau is whether it has been continually occupied or if humans have moved in and out of the region (e.g., see Berry 1982). The paper by Geib presents an argument, through radiocarbon dating of artifacts, that the central Colorado Plateau has been continuously occupied since 9000 BP.

Some of the most frequently encountered artifacts at archaeological sites on the Colorado Plateau are ceramic potsherds (Colton and Hargrave 1937). In many instances, archaic cultures have been identified as having unique ceramic pottery styles, and the Fremont culture is no exception (Gunnerson 1957). In the second paper of this section, Spurr presents an examination of the composition of Emery Gray ceramics of the Fremont culture to support the contention that the present classification is not adequate because of inaccurate and inconsistent temper designations.

The third paper provides an example of how research can cross disciplines. Floyd-Hanna, Romme, Loy, and Hanna provide managers with a model that predicts fires and, ultimately, their effects on cultural resources. Because no trees with fire scars were present in their Mesa Verde study area, the authors developed a technique with which to date vegetation recovery.

The fourth paper addresses social research on the Colorado Plateau. Solop and Rodriquez present the results of a telephone survey of Arizona residents that examines public attitudes toward protecting resources of Grand Canyon National Park. Specifically, the authors attempted to gauge frequency of use, levels of concern for protecting Grand Canyon resources, and finally at what level people were willing to endure financial costs to support public policies of park preservation.

\section{Biological Resources}

The final section addresses research that has been carried out on biological resources across the Colorado Plateau. The section is subdivided into plant and animal groupings. The plant papers encompass a vegetation scheme for the Colorado Plateau, an analysis of hanging gardens, and a chapter on tissue culture techniques for ponderosa pine (Pinus ponderosa). The animal papers are organized by taxonomic level, beginning with amphibian surveys and reptile body temperatures as related to movement patterns, through several papers on birds, and ending with a paper on a mammalian reproductive cycle.

The initial paper might ultimately prove to be one of the most important of this volume. Spence, Romme, Floyd-Hanna, and Rowlands provide a vegetation classification scheme for scientists and managers on the Colorado Plateau. This paper is an accumulation of several years of work by the Colorado Plateau Vegetation Advisory Committee (CPVAC), whose charge was to construct a standardized vegetation theme on the Colorado Plateau for managers.

The second paper revisits hanging gardens to address the endemicity of plants. Fowler, Stanton, Hartman, and May examined 48 hanging gardens in Zion and Capitol Reef national parks and Glen Canyon National Recreation Area to provide evidence of the importance of these plant species to hanging gardens. 
Ponderosa pine is probably the most important economic tree species on the Colorado Plateau. For this reason, silviculturists have paid considerable attention to the production of young trees that would ultimately prove most suitable for timber production. Lin and Wagner, in the third paper, discuss the methodologies they developed to produce plantlets of ponderosa pine from callus induction and differentiation.

The initial animal paper of this Proceedings is by Drost and Sogge and deals with a survey of northern leopard frogs (Rana pipiens) along the Colorado River in Glen Canyon National Recreation Area. This paper is important because of the serious declines of anuran amphibians throughout much of North America (see the 1990 paper by Barinaga for a succinct overview of this problem).

The fifth paper features reptiles: Graham, Persons, Schaedla, and Moore relate a study of body temperature patterns of western rattlesnakes (Crotalus viridis) at Natural Bridges National Monument. Twelve snakes were implanted with temperature-sensitive radios that revealed lower body temperatures than reported from other species of rattlesnakes.

Johnson and Sogge present the first paper on birds - about the influence that livestock corrals and associated food items have on the abundance and distribution of brown-headed cowbirds (Molothrus ater) in Grand Canyon National Park. The authors examined five locations where livestock concentrate in the park and found cowbirds frequenting three sites (two in Grand Canyon village and one at Yaqui Point).

The second bird paper is from a 7-year study reporting on observations at a great blue heron (Ardea herodias) colony adjacent to Curecanti National Recreation Area in Gunnison, Colorado. Graham and Meyer documented the gradual movement of heron nests west from Gunnison's city borders as the human population expanded and documented the expansion of the heron colony, which doubled in 5 years.

The last paper pertains to the reproductive cycle of Abert's squirrels (Sciurus aberti). This mammal is, much like hanging gardens, a unique aspect of the Colorado Plateau (Hoffmeister 1971). Pogany and Allred relate their research in which, from 1992 through 1994, they collected squirrels killed on roads in Grand Canyon National Park and Walnut Canyon National Monument. Each specimen was examined histologically to determine the phenology of the species' reproductive cycle.

\section{Abstracts}

\section{GEOMORPHOLOGY OF THE HANGING GARDENS OF THE COLORADO PLATEAU}

Cathleen L. May, James F. Fowler and Nancy L. Stanton

A roughly J-shaped archipelago of island habitats is distributed within the drainage system of the Colorado Plateau from the Zion area at the southwest to the canyons of the Green and Yampa rivers in the northeast. This is the hanging garden habitat. Hanging gardens are isolated mesophytic communities physically and biologically distinct from surrounding xerophytic or riparian communities. Geologic and hydrologic parameters control the existence, distribution, and physical attributes of the hanging garden habitat. Attributes vary with the sedimentologic type of the different aquifer-bearing geologic formations in which gardens develop. Within a given foundation, garden habitat attributes are relatively consistent. This observation allows a simple, informative, and predictive model of garden geomorphology to be applied across the geographic range of the system. The sandstone aquifers of the Colorado Plateau provide the necessary condition for hanging garden development-a perennial, seepdelivered water supply and an absence of significant fluvial processes. An erosional process called groundwater sapping yields protective geomorphology that shields the habitat from the aridity of the region as well as extrinsic erosional processes. Discharge rate and the lithology of the seep-supplying geologic formation determine the size, shape, distribution, and abundance of microhabitats within a 
hanging garden. Colonization of microhabitats is determined by the ecological requirements and by the biogeographic and evolutionary history of individual species making up the hanging-garden community. Diversion of the seep supply and erosion of colluvial soil by human foot traffic and livestock use affect garden ecology negatively. Hanging gardens should be protected from both activities. Local and regional alteration of patterns of aquifer flow may affect the hanging-garden ecosystem.

Keywords: Biogeography, ecology, groundwater sapping, hydrology, mesophytic community.

\section{GIANT SANDSTONE WEATHERING PITS NEAR COOKIE JAR BUTTE, SOUTHEASTERN} UTAH

\section{Dennis I. Netoff, Brian J. Cooper, and Ralph R. Shroba}

In arid southeastern Utah, giant weathering pits in the lower member of the Entrada Sandstone of the Middle Jurassic age are striking features of the landscape near Cookie Jar Butte in Glen Canyon. The pits are larger than most of those described in the geologic literature (as wide as $38 \mathrm{~m}$ and as deep as $16.5 \mathrm{~m}$ ). Four pit types identified on the basis of cross-sectional form are cylinders (the most abundant type), bowls, armchairs, and pans. Sandy sediment commonly veneers the bedrock floor of all pit types. The sediment is similar in character to the adjacent sandstone and is probably locally derived. Many of the deeper pits retain water from months to years, and water temperature and $\mathrm{pH}$ values vary considerably by season. Vegetation in pits that are not periodically inundated with water differs by type and amount; pits with the thickest sediment tend to have the densest cover. Laboratory analyses of sandstone from pit walls, floors, and rims reveal a fine-grained ( $\overline{\mathrm{x}}$ diameter about $90-100 \mu)$ arkosic sandstone that is weakly cemented with $\mathrm{CaCO} 3$ (2.7-9.1\% by weight) and lesser amounts of clay.

Thin-section analyses of the sandstone cores reveal quartz, plagioclase, and potassium feldspars that are relatively unweathered, and examination using a scanning electron microscope indicates that most grains are coated with variable thicknesses $(0-5 \mu)$ of clays and iron oxides - interstitial clays constitute $1-6 \%$ of the total sample. Physical weathering such as spalling, salt crystal growth, and clay mineral hydration and dissolution of carbonate cement weaken the sandstone. The sediment produced by these processes is probably removed by wind, plunge-pool action, and perhaps dissolution and piping. The cause of the removal of pit sediment is unknown.

Keywords: Entrada Sandstone, Glen Canyon National Recreation Area, pothole, tinaja, water pocket.

\section{LARGE-SCALE GEOLOGIC MAPPING IN GREAT BASIN NATIONAL PARK, NEVADA}

Janet L. Brown and Vidal Davila, Jr.

Great Basin National Park is located in the southern Snake Range, White Pine County, Nevada, near the ranching community of Baker, Nevada. The Great Basin National Park project began in June 1992 through an interagency agreement between the U.S. Geological Survey (USGS) and the National Park Service (NPS) and was completed in March 1995. The project delivers large-scale geologic maps of the park, a Geographic Information System data base shared between the USGS and NPS, USGS Open-file and Geologic Quadrangle geologic maps, reports on topical studies, and a USGS bulletin on the geologic evolution of the park. The park includes the southern Snake Range, recognized as a metamorphic core complex and exposing the Snake Range decollement, a large-scale, low-angle fault plane surface. Studies are conducted on important regional problems like the age, time of initiation, style, and kinematics of extension in the Basin and Range Geologic Province. Results to date conclude that extension in the Snake Range began from 20 to $15 \mathrm{Ma}$ (million years; early to middle Miocene) earlier than had been previously thought. Products from this project provide data to develop responses to preservation and management issues, to answer requests for public information, and to provide a basis for continued scientific research in the region. 
Keywords: Extension tectonics, geographic information systems, Snake Range decollement, southern Snake Range.

USING LAND-BASED PHOTOGRAMMETRY TO MONITOR SANDBAR STABILITY IN GRAND CANYON ON A DAILY TIME SCALE

Leland R. Dexter, Brian L. Cluer, and Mark F. Manone

We report on the development of a method used to monitor spatial characteristics of subaerial alluvial sediment storage using automatic, time-lapse, 35-mm cameras. The cameras are fixed to bedrock in a protective canister, aimed at low oblique angles toward alluvial deposits of interest, and set to trigger once every $24 \mathrm{~h}$. Presently, 43 sandbars are monitored with single cameras, and one sandbar is monitored with two cameras arranged to give stereographic coverage. The color 35-mm images are scanned electronically for input into PC ERDAS for digital manipulation and analysis, and the original transparencies are archived. Digital images are then sequenced and written to compact disk or video tape to produce time-lapse visualizations. Methods were developed to transform the digital image from oblique to planimetric. Aerial extent of sediment cover could then be estimated by several methods. Error analysis of transformed images showed that third-order transformations provided the optimal balance between control and accuracy. Third-order transforms were within $\pm 1 \mathrm{~m}$ to $95 \%$ confidence. We captured significant changes in 28 separate sandbar deposits in at least 79 separate events displaying typical return intervals of 105 to 110 days. Most beach failures recorded by these methods occurred following low-flow discharges on weekends. We document rapid erosion (typically completed within 1 day) followed by slower deposition (typically lasting 2 weeks).

Keywords: Colorado River, fluvial erosion, image analysis.

\section{RADIOCARBON RECORD FOR ARCHAIC OCCUPATION OF THE CENTRAL COLORADO PLATEAU}

Phil R. Geib

The traditional view of Archaic hunter-gatherer occupancy of the Colorado Plateau assumes population continuity and gradual evolutionary change. An alternative model contends that the Archaic period was punctuated by regional abandonments and reoccupations resulting in a succession of new lifeways and material culture. The numerous preceramic radiocarbon dates obtained from the central Colorado Plateau in the last 2 decades are tabulated and graphically summarized to provide a context for evaluating these two models. Long-term continuity in occupancy throughout the Archaic period is supported. Adaptive shifts that involved increased residential mobility and changes in settlement pattern probably account for previous gaps in the Colorado Plateau radiocarbon record, such as the 1,000 year interval during the middle Archaic (ca. 6000-5000 B.P. [before the present]). Because of the exceptional preservation of subsistence remains and perishable technology within numerous stratified dry shelters, copious paleoenvironmental data from a variety of sources, and occupation throughout the Archaic period, the central Colorado Plateau emerges as a highly productive area for studying huntergatherer adaptations and economic transitions, inducing the adoption of agriculture.

Keywords: Archaic period, chronology, Glen Canyon, hunter-gatherers, Southwest prehistory.

\section{COMPOSITIONAL ANALYSIS OF TEMPER IN EMERY GRAY CERAMICS FROM CENTRAL UTAH \\ Kimberly Spurr}

Emery Gray ceramics of the Fremont culture are characterized by crushed igneous rock temper. Several temper types that appear distinct under the binocular microscope are included in this ceramic 
type, and the relation of these temper types and the sources of the rocks have been debated. Emery Gray sherds from a site in central Utah were used to address this research question. Analysis with the petrographic microscope and electron microprobe indicates that the composition of feldspars in two distinct temper types is similar. Samples of potential source rocks collected near the site also were analyzed and compared with the temper samples. The feldspar composition of the rocks and the Emery Gray sherd temper are comparable and the mineral assemblages also are similar. Combining the compositional data with the distribution of the several rock types revealed patterns that can be used to determine the location of production and patterns of distribution of Emery Gray ceramics. These patterns provide information on resource use by Fremont peoples. The data may also be useful in refining the classification system for Fremont ceramics.

Keywords: Ceramic production, Fremont, Utah prehistory.

\section{A MODEL TO STUDY FIRE EFFECTS ON CULTURAL RESOURCE STUDIES OF MESA VERDE} Lisa Floyd-Hanna, William H. Romme, Allan Loy and David D. Hanna

On 8 July 1989, lightning struck the dry terrain of Long Mesa in Mesa Verde National Park and ignited a 2-week burn that scorched 1,200 ha. As a result, park management initiated studies of the effects of high-intensity fire on cultural resources. Mesa Verde National Park was established to protect works of prehistoric humans including pit-houses and cliff dwellings of the Anasazi. Later, park management was charged with the preservation of historic buildings and wood structures of 20thcentury Americans. Our research will provide the necessary background information to predict specific fire effects on cultural sites. We mapped the vegetation communities, reconstructed the prehistoric fire history of half of Mesa Verde, and will document postfire succession. These data sets, incorporated into spatially explicit layers in the park's Geographic Information System, will be used to model the risk and specific effects of fire as related to particular classes of cultural resources.

Keywords: Anasazi, postfire succession, vegetation mapping.

\section{PUBLIC SUPPORT FOR PROTECTING GRAND CANYON RESOURCES}

Frederic I. Solop and Elaine Rodriquez

Personnel of the Social Research Laboratory at Northern Arizona University surveyed the adult human population of Arizona to explore public attitudes toward protecting Grand Canyon resources. The telephone survey of 402 adult Arizona residents was conducted between 22 and 28 February 1993. Survey results indicate widespread (74\%) support for resource protection at the Grand Canyon. Regardless of the nature of the threat, citizens support a variety of resource protection strategies. The survey also indicates that citizens are willing to incur personal costs to protect Grand Canyon resources. Keywords: Arizona, attitudes, national park, policy, survey.

\section{A PRELIMINARY VEGETATION CLASSIFICATION FOR THE COLORADO PLATEAU} John R. Spence, William H. Romme, Lisa Floyd-Hanna and Peter G. Rowlands

A new vegetation classification is developed and applied to the Colorado Plateau. The SpenceRomme-Floyd-Hanna-Rowlands (SRFR) classification is loosely based on the Brown-Lowe-Pase system. The SRFR classification is hierarchical and open-ended and can be adapted to any region of North America. The levels in the hierarchy, from broad scale to fine scale, are biogeographic realm, floristic province, climate-elevation zone, plant formation, series, and association. A preliminary classification of the vegetation of the Colorado Plateau is presented to the series level. Keywords: Biome, climate zone, formation, plants, series. 


\section{LEVEL OF ENDEMISM IN HANGING GARDENS OF THE COLORADO PLATEAU}

James F. Fowler, Nancy L. Stanton, Ronald L. Hartman and Cathleen L. May

Infrequent seeps and springs along xeric canyon walls of the Colorado Plateau support

hydrophytic habitats called hanging gardens. We surveyed the level of endemism among vascular plant taxa of hanging gardens in three National Park Service units: Zion and Capitol Reef national parks and the Glen Canyon National Recreation Area. The number of hanging-garden endemics per hanging garden was significantly higher in the Glen Canyon National Recreation Area than in Zion National Park or in Capitol Reef National Park $(F=8.640, P=0.001)$. This higher level of endemism was not because of larger hanging gardens or higher richness of vascular plant species per garden. Community importance of endemic plant taxa as measured by species canopy coverage has a range of $0-52 \%$. The canopy coverage of hanging-garden endemics did not differ among the three parks $(\mathrm{F}=1.740, \mathrm{P}=$ $0.189)$.

Keywords: Capitol Reef, Glen Canyon, species richness, vegetation community, Zion

\section{TISSUE CULTURE OF MATURE PONDEROSA PINE: CALLUS INDUCTION AND DIFFERENTIATION}

Yiqun Lin and Michael R. Wagner

Callus was induced from needle segments of mature ponderosa pine (Pinus ponderosa Doug. ex Laws.). Callus formation was significantly affected $(\mathrm{P} \leq 0.01)$ by four growth-regulator treatments and the position along needle segments. The highest frequency of callus formation (57\%) was obtained with Murashige-Skoog (MS) medium containing $0.5 \mathrm{mg} / \mathrm{L}$ BAP (benzylaminopurine) and $1.0 \mathrm{mg} / \mathrm{L}$ 2,4-D (2,4-dichlorophenoxyacetic acid). The needle segments located in the middle part of the axis responded best, as measured by callus formation, to the tested treatments. Three callus lines were grown by applying two subcultures for subsequent study of callus differentiation. Semithin sections of callus tissue from the second subculture revealed a vascular nodule (tracheid masses with cambiumlike structure), and meristematic tissue had formed in the lower part of callus cultured in MS medium containing $0.03 \mathrm{mg} / \mathrm{L} \mathrm{NAA}$ (naphthalene acetic acid) $+0.5 \mathrm{mg} / \mathrm{L}$ BAP. Among three callus lines, only line 2 - treated with $0.5 \mathrm{mg} / \mathrm{L} 2,4-\mathrm{D}+1.0 \mathrm{mg} / \mathrm{L} \mathrm{BAP}$ - developed a vascular nodule and meristematic tissue after transfer to two subculture media.

Keywords: Callus formation, meristematic tissue, needles, phytohormones, Pinus ponderosa, vascular nodule.

\section{PRELIMINARY SURVEY OF LEOPARD FROGS IN GLEN CANYON NATIONAL RECREATION} AREA

\section{Charles A. Drost and Mark K. Sogge}

Collection records and published reports indicate that the northern leopard frog (Rana pipiens) was formerly widely distributed along the Colorado River corridor in the area that is now Glen Canyon National Recreation Area. This species has experienced serious declines over much of its range in western North America. We report on a newly discovered population along the Colorado River in Glen Canyon National Recreation Area, and two new populations in tributaries of Lake Powell. Recent surveys suggest that the river site supports the sole remaining leopard frog population between Glen Canyon Dam and Lake Mead. This population is vulnerable because of its small size (80-100 individuals), its isolation, and because of possible effects from planned increased high flows from Glen Canyon Dam.

Keywords: Amphibian decline, Colorado River, conservation, Rana pipiens. 


\section{TEMPERATURE PATTERNS OF RATTLESNAKES AT NATURAL BRIDGES NATIONAL} MONUMENT, UTAH

Tim B. Graham, Trevor Persons, William Schaedla, and Donald Moore

We implanted 12 western rattlesnakes (Crotalus viridis) with temperature-sensitive radios; 4 each in 1989 and 1990 and 7 in 1991 (3 snakes were tracked for 2 years). Individual snakes were tracked for 1 to 2 years and were located daily while active. Average body temperature for this population was $22.5^{\circ} \mathrm{C} \pm 6.98^{\circ}$ (range $18.4-26.7^{\circ} \mathrm{C}$ ). Body temperatures were low relative to body temperatures reported for $C$. viridis and other species of rattlesnakes. Substrate temperature best predicted body temperature, but air temperature played a role in determining body temperature for many snakes. In 1990, an incubating female maintained a higher and more constant body temperature than any other snake in the study during the 3 years, including her own temperature in 1989. Except during gestation, western rattlesnakes at Natural Bridges apparently will accept lower body temperatures to meet other physiological needs.

Keywords: Body temperature, Crotalus, radiotelemetry, reproductive ecology, thermoregulation.

\section{COWBIRD CONCENTRATIONS AT LIVESTOCK CORRALS IN GRAND CANYON NATIONAL} PARK

Matthew J. Johnson and Mark K. Sogge

Brown-headed cowbirds (Molothrus ater) at Grand Canyon National Park parasitize broods of many neotropical migrants including the southwestern willow flycatcher (Empidonax traillii extimus). We conducted surveys from 16 May through 28 July 1993 for brown-headed cowbirds at horse and mule corrals at five sites in the Grand Canyon, noting presence, abundance, sex, and foraging habits of cowbirds. Brown-headed cowbirds were detected at three of five pack stations where they foraged on grain, hay, mule dung, and insects. Cowbird numbers were lowest in the morning (before $1000 \mathrm{~h}$ ) and increased thereafter. Brown-headed cowbirds are known to spend mornings in breeding areas and concentrate at foraging centers during midday. Corrals along the rim are providing important foraging centers for cowbirds and may be allowing these cowbirds to brood parasitize nests of other bird species in local forest and riparian areas.

Keywords: Brood parasitism, brown-headed cowbird, monitoring, neotropical migrants.

\section{OBSERVATIONS OF A GREAT BLUE HERON COLONY FROM 1987 TO 1993}

Tim B. Graham and Ron W. Meyer

Great blue herons (Ardea herodias) have nested near Gunnison, Colorado, for at least 40 years. Since 1970, city expansion has forced the birds west; the colony is now located adjacent to Curecanti National Recreation Area in cottonwoods (Populus angustifolia) on private land. Observations of population size and reproductive success were made each year since 1987. Occupied nests more than doubled over the past 5 years, and the population seems to have stabilized at about 80 active nests. No immediate threats exist to the colony or to foraging areas, but the long-term survival of the colony is a concern. Cattle grazing under trees within the colony prevents recruitment of cottonwoods. Absence of regeneration will limit the colony as existing trees die. Future changes in land ownership or land uses could affect the colony as well.

Keywords: Ardea herodias, land use, reproduction, threats.

ABERT'S SQUIRRELS OF THE COLORADO PLATEAU: THEIR REPRODUCTIVE CYCLE Gilbert C. Pogany and W. Sylvester Allred 
Results of a morphological and histological analysis of Abert's squirrels (Sciurus aberti aberti) killed on the road are presented. Resolving either the sex or the age of the animals on the basis of body measurements is not possible. Plotting testis weight against body length, however, seems to differentiate between juvenile and adult animals. Testicular activity, as judged from weight increases and histological analyses, displays a broad pattern that begins in October and ends in May-June when testicular regression ensues. Testicular regression is not complete because some residual meiotic activity is retained even through September and October. This maintenance meiosis serves to preserve the testes in a state of preparedness from which rapid recrudescence can be implemented. Evidence for dual gestation in Abert's squirrels is indicated by actual embryos and the presence of lactating nipples. Keywords: Embryos, gestation, reproduction, spermatogenesis, testis.

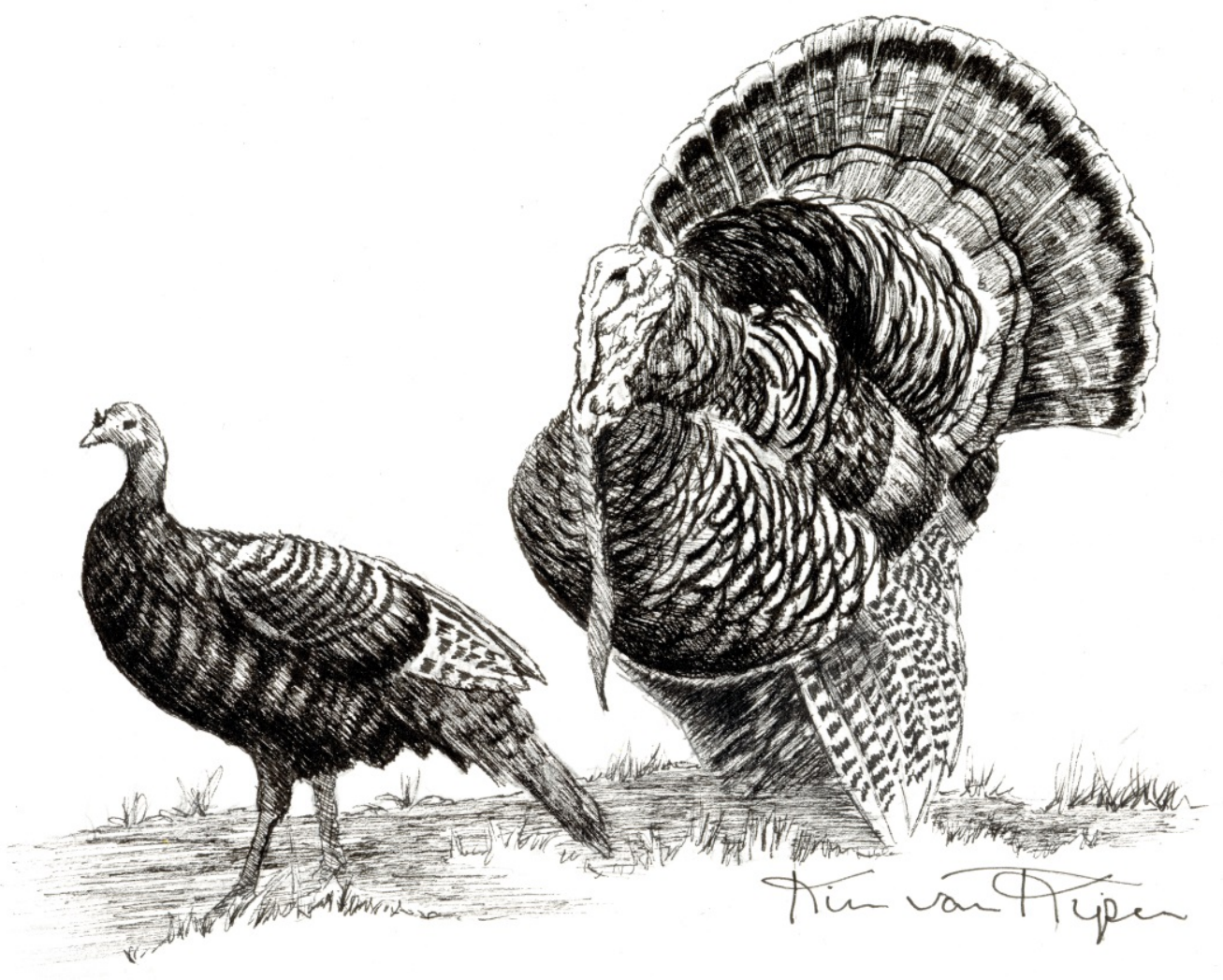

Drawing of wild turkey, Meleagris gallopavo (copyright and courtesy of Kimberly Ann van Riper). 


\title{
Proceedings of the Third Biennial Conference of Research on the Colorado Plateau
}

\author{
Edited by Charles van Riper III and Elena T. Deshler
}

The 16 chapters in this Proceedings were selected from 83 research papers presented at the Third Biennial Conference of Research on the Colorado Plateau. The conference, held in Flagstaff, Arizona on 17-20 October 1995, was hosted by The National Biological Service's Colorado Plateau Research Station (formerly National Park Service Cooperative Park Studies Unit, and now U.S. Geological Survey/Biological Resources Division/Colorado Plateau Field Station), and Northern Arizona University. The theme of this biennial meeting centered around research, inventory, and monitoring on federal, state, and private lands over the Colorado Plateau.

This is the third volume, in a planned series of Colorado Plateau Biennial Conference Proceedings, that highlights research and resource management efforts related to biological, physical, and cultural resources within the biogeographic province of the Colorado Plateau. Many of the papers published in this Proceedings Series have emanated from questions that arose while examining Colorado Plateau resource issues. Because of resource similarities across the Plateau, techniques that work in one management unit are applicable to numerous other management areas. Many protocols, especially those related to monitoring techniques, presently being utilized in lands over the Colorado Plateau stem from aspects of the scientific works published in this Proceedings Series.

Each paper selected for publication represents original research and has been peer-reviewed by a minimum of two reviewers in that particular research discipline. As with the previous two volumes, the papers naturally divide themselves into three major sections: (1) physical resources; (2) cultural resources; and (3) biological resources. However, in this volume the preponderance of contributed papers are from the biological resources arena. Therefore, we start the volume with biological papers, followed by chapters that deal with physical resources, ending with chapters on cultural aspects of the Colorado Plateau.

\section{Biological Resources}

It is fitting to begin this section, and book, with a chapter dealing with a unique aspect of the Colorado Plateau - an endangered native fish, the humpback chub. The R. Valdez chapter is a capstone work that summarizes the many years of research that he has conducted on this endangered species within the 226 miles of the Colorado River from Glen Canyon Dam to Diamond Creek. Valdez and Ryel provide a detailed section on fish distribution patterns among regions of the river. Chub reproduction, coupled with age and growth patterns, provide insight into why this species has become endangered. The authors also provide information on survival, predation rates, and parasite levels within the chub population. The second chapter moves to mammals, with S. Rosenstock providing information on the desert rodent communities of grassland, shrubland, and woodland habitats of Capitol Reef National Park. The relatively simple small mammal assemblages that he found parallel the morphology and resource use of small mammals in other North American deserts, suggesting consistent mechanisms that minimize competition and facilitate coexistence. A second mammal chapter, by R. Ockenfels et al., deals with home range size and movement patterns of pronghorn antelope in northeastern Arizona. These authors found that females had larger home ranges than males and that the home range patterns of 
both sexes were greatly influenced by anthropogenic barriers. The pronghorn freely crossed pasture fences and unfenced roads, but were restricted from crossing fenced roads and fenced railroad rights-ofway. The authors do provide several management alternatives on how to alleviate problems associated with maintaining pronghorn movement across the landscape in Arizona. Chapter 4, by D. Foster et al., is the final mammal study and provides information on distribution of bat species over 5 million acres of forested lands on the southern Colorado Plateau. The authors mistnetted, recorded vocalizations, and utilized an echolocation device at water holes, in an effort to determine the presence and relative abundance of bat species throughout forested regions around Bryce Canyon National Park. The 14 recorded bat species represent sound baseline information for this mammal group over portions of the southern Colorado Plateau.

The narrow strips of riparian vegetation, present throughout the southwestern United States, are extremely important to wildlife, and especially so to avian communities. However, these narrow habitat bands provide a challenge to the development of census and monitoring techniques because of the difficulty in identifying techniques that will realistically define changes in avian species numbers and community composition. In Chapter 5, D. Felly and M. Sogge provide a comparison of survey techniques for monitoring birds in riparian vegetation patches along the Colorado River corridor within Grand Canyon National Park. They compare absolute-count with point-count surveys. Their conclusions encourage managers to employ point-count surveys in this habitat, as the authors feel it would be the most effective tool to monitor trends in breeding bird abundances and species composition. The following two chapters also deal with birds, specifically with management questions related to the wild turkey in Arizona. Chapter 6 analyzes the effect of timber harvest on Merriam's turkey loafing habitat. In their analysis of pre- and post-timber harvest sites, B. Wakeling et al. conclude that turkeys need a high canopy density, low horizontal visibility, and contiguous suitable habitat if an area will continue to be used for loafing. In the next chapter, the same lead author documents winter movement patterns of turkeys as related to their overnight roost sites. Wakeling's findings demonstrate that turkeys concentrate their activities close to roost sites $(<0.8 \mathrm{~km})$, therefore suggesting that forest manipulation activities should be avoided within $0.8 \mathrm{~km}$ of known roosting areas.

The next five chapters (8-12) of this Proceedings deal with vegetative aspects of Colorado Plateau ecosystems. Haywood et al. assess potential use of the model PROGNOSIS in Arizona forests. The PROGNOSIS model predicts potential suitable wildlife habitat from canopy closure estimate data taken during determination of a stand density index (SDI). The data set developed by the authors, from 230 random vegetation plots over 10,000 ha in the Kaibab Forest, revealed that the PROGNOSIS model explained less than $50 \%$ of the variation in the Arizona forest SDI data set. Thus, the authors caution on the use of PROGNOSIS for defining suitable wildlife habitat in Arizona, suggesting that small vegetation sample plots do not provide an accurate indication of forest cover. Chapter 9 documents the status of the rare Goodding's willow along the Colorado River in Grand Canyon National Park. Mast and Waring, through tree core sampling, demonstrate the influence of Glen Canyon Dam and flood events on this tree species. The authors also document a recent shift in the distribution of the Goodding's willow from the upper to lower canyon regions.

The next two vegetation chapters deal with broad scale analyses of forest stand structure over the southern Colorado Plateau. In Chapter 10, Garrett et al. examine North Kaibab National Forest overstory between 1910 and 1993. They compare analyses from USFS surveys of forest structure from 1910, 1955, 1977 and 1993, showing that smaller and larger classes of trees have increased in density, even with forest product removal. They caution that, with current forest management practices, $25 \%$ of the forest is at high risk and $65 \%$ at medium risk to catastrophic wildfire or insect/disease loss. Menzel and Covington (Chapter 11), utilizing dendroecological techniques, demonstrate a similar change in the 
ecotonal Pinus ponderosa and Pinus edulis forest at Walnut Canyon National Monument, east of Flagstaff, Arizona. They show that subsequent to Euro-American settlement (circa 1876), trees greater than $10 \mathrm{~cm}$ diameter at breast height (dbh) have increased in numbers from 72 to $333 \mathrm{stems} / \mathrm{ha}$, and increased in basal area from 9.0 to $19.1 \mathrm{~m} 2 / \mathrm{ha}$. In this forest, however, the contribution of Pinus ponderosa larger than $10 \mathrm{~cm}$ dbh actually decreased (from $80 \%$ to $68 \%$ ) while numbers of Pinus edulis, Quercus gambelii, and Juniperus spp. increased in this tree size class. The authors conclude their chapter with seven management alternatives that might be employed to restore this forest to preEuropean conditions.

The final vegetative and biological chapter (chapter 12 by T. Graham) describes recovery of a hanging garden from a 1990 fire. Hanging gardens occur over sections of the Colorado Plateau because of unique geologic and hydrologic features. Previous work on this garden in 1983, by Dr. Stanley Welsh of Brigham Young University, provided a baseline of information from which Graham could compare the 5-year recovery of this isolated vegetative community. After monitoring (on an annual basis) soil bacteria, nematodes, and fungi, along with plant species, Graham concluded that recovery for all groups was directly related to soil moisture content. Those areas that did not receive direct moisture from the seeps were still devoid of plants and most microorganisms in 1995, while watered locations have recovered a complete complement of flora and soil fauna.

\section{Physical Resources}

The Proceedings now turns to physical aspects of the Colorado Plateau. Chapter 13 by Meretsky and Melis is a transition work that outlines the coordination of biological with physical analyses of data collected during Phase II of the Glen Canyon Environmental Studies (GCES) project. The GCES research effort, directed by Dave Wegner, was a multimillion dollar Bureau of Reclamation project that spanned a period of 12 years, examining the impact on resources along the Colorado River from construction of the Glen Canyon Dam. This chapter summarizes work from Phase II (1989-1993) and how biological and physical information was integrated to produce the 1994 final GCES Environmental Impact Statement. Chapter 14, by Kennedy et al., describes the depositional environment of Tapeats sandstone in Grand Canyon National Park. From 21 localities, their paleoslope and sedimentological data suggests that this sandstone layer was deposited in deeper waters, not in near-shore environments as was formerly believed. In some instances they argue that sediments were deposited at an excess of $200 \mathrm{~m}$ below storm wave base. Further support for their conclusions is provided by the breccia matrix that they examined at Ninety-one Mile Canyon, which indicates sediment deposition in a reducing environment.

\section{Cultural Resources}

Chapter 15 is a brief summary on baseline noise levels and the potential invasion of natural quiet to visitors at Bryce Canyon National Park. To complete this study, Dan Foster established five monitoring locations throughout the park, recording ambient noise levels of jets, helicopters, and fixedwing aircraft from May to August of 1995. His results establish the types and duration of non-natural noise occurring in the park, providing a baseline that will aid NPS managers in working with future impacts that degrade 'natural quiet' within the region.

The Proceedings closes with an archeological chapter that describes a high altitude agricultural site on the Colorado Plateau. The authors, W. Fawcett and J. Bright, claim that this is one of the highest elevations at which intensive agriculture existed during the first millennium A.D. The water control features that they found, coupled with corn remains at different levels in the excavated cave floor, led 
the authors to suggest that the inhabitants relied heavily on domesticated cultigens, thus indicating that not all Anasazi were hunter-gatherers during this prehistoric time period.

\section{Abstracts}

\section{LIFE HISTORY AND ECOLOGY OF THE HUMPBACK CHUB IN THE COLORADO RIVER IN} GRAND CANYON, ARIZONA

Richard A. Valdez and Ronald J. Ryel

The endangered humpback chub (Gila cypha) is found as six populations in the Colorado River Basin. The largest is in Grand Canyon, Arizona, where in 1990-1993, fish were distributed as nine aggregations in $307 \mathrm{~km}$ of the Colorado River, as well as in the lower $14.9 \mathrm{~km}$ of the Little Colorado River (LCR), a seasonally-warmed tributary. An estimated 3,700 adults inhabited the mainstem in 1993, with 3,480 adults in the largest aggregation near the LCR. The LCR was the only area with significant spawning and recruitment of fish to the mainstem, but it was used only by the nearby mainstem aggregation and a resident LCR population. Year-round releases of $8-10^{\circ} \mathrm{C}$ water from Glen Canyon Dam precluded successful mainstem reproduction and limited growth of young chubs. Adults exhibited a high degree of spatial fidelity for specific river locales; mean net movement was $1.49 \mathrm{~km}$ (range $=0$ 6.11; $\mathrm{SD}=1.50)$ for 69 radio-tagged fish and $1.64 \mathrm{~km}$ (range $=0-99.8 ; \mathrm{SD}=1.72)$ for 238 Passive Integrated Transponder (PIT)-tagged fish. Annual survival of chubs during the first 3 years of life was estimated at 0.10 , while estimated annual survival of adults (age $3+$ ) was 0.93 . A major source of subadult mortality was predation by brown trout (Salmo trutta) and channel catfish (Ictalurus punctatus), which together potentially consumed about 228,850 chubs annually. Adult chubs inhabited primarily large recirculating eddies ( $88 \%$ captures, $74 \%$ radio contacts), whereas subadults used shorelines with vegetation, talus, and debris fans, as well as eddy return channels (i.e., backwaters). Diet by volume of mainstem adults near the LCR consisted of Gammarus lacustris (freshwater amphipods, 45\%), Simuliidae (blackflies, 40\%), terrestrial invertebrates (9\%), Chironomidae (midges, 5\%), and other aquatic invertebrates (1\%). Adults from more downstream aggregations consumed a lower proportion of $G$. lacustris and a higher proportion of terrestrial invertebrates. External parasitic copepods (Lernaea cyprinacea) were on 8 of 6,294 (<1\%) chubs examined and Asian tapeworms (Bothriocephalus acheilognathi) were in guts of 6 of $168(4 \%)$ adults flushed with a stomach pump. Keywords: Annual survival, Colorado River, diet, endangered species, Gila cypha, Grand Canyon National Park, humpback chub, parasites, predation, reproduction.

\section{DESERT RODENT COMMUNITIES OF THE CANYON COUNTRY PROVINCE, COLORADO PLATEAU \\ Steven S. Rosenstock}

From 1988-1991, I studied desert rodent communities of the Canyon Country Province, Colorado Plateau. Study areas were located in Capitol Reef National Park, Utah and represented grassland, shrubland, and woodland habitats. I examined species richness, guild structure, body size, and microhabitat use, testing predictions based on patterns documented in other North American desert rodent faunas. Rodent assemblages were relatively simple with respect to species richness and number of taxonomic/foraging guilds. Among coexisting species, only the numerically dominant omnivores exhibited non-random body size. Co-occurrences of species representing three taxonomic-foraging guilds were significantly different from expected and, in one case, correlated with microhabitat use. Desert rodents of the Canyon Country have evolved patterns of morphology and resource use similar to those documented in other North American deserts that may minimize competition and facilitate coexistence. 
Keywords: Body size, community structure, desert rodents, microhabitat.

\section{HOME RANGES AND MOVEMENTS OF PRONGHORN IN NORTHERN ARIZONA} Richard A. Ockenfels, William K. Carrel and Charles van Riper III

During October 1992, we captured 17 adult pronghorn (Antilocapra americana) within the environs of Wupatki National Monument (NM), Arizona, and 20 adults in or near Petrified Forest National Park (NP), Arizona. Each animal was relocated over the next two years to determine homerange sizes, movement patterns, and movement barriers. The greatest distance between any two consecutive locations was the only variable having a substantial effect on home-range size; neither animal gender nor mean distance between locations added to the predictive ability. Multiple core use areas were more evident for females and their home ranges were significantly larger in Wupatki NM than in the Petrified Forest NP environs. Unfenced, 2-lane paved roads did not restrict pronghorn movements within either park, and no peak crossing periods were discernible. However, fenced, paved 2-lane roads and fenced, divided 4-lane highways outside of the parks constituted movement barriers. Furthermore, fenced railroad rights-of-way were barriers and influenced shapes of pronghorn home ranges. Pronghorn populations in Northern Arizona can, therefore, be partially defined by highway and railroad barriers. These barriers could be modified to facilitate pronghorn interchange by either: (1) removing fencing; (2) expanding rights-of-way dimensions, then modifying fences; or (3) relocating rights-of-way out of pronghorn habitat. Knowledge of pronghorn home ranges and movements can be used to better manage populations, plan land uses, and mitigate human-related activities.

Keywords: Antelope, Antilocapra americana, fences, geographic information systems, highways, home ranges, movements, Petrified Forest National Park, pronghorn, railroads, rights-of-way, Wupatki National Monument.

INVENTORY OF BATS IN HIGH PLATEAU FORESTS OF CENTRAL AND SOUTHERN UTAH Dan A. Foster, Laura Grignon, Evan Hammer, and Brian Warren

Bats utilizing water sources within plateau forests were surveyed at 24 sites in southern and central Utah. Fourteen taxa were captured, with eight of these formerly listed by the U.S. Fish and Wildlife Service as Category 2 species. The first documented capture of Euderma maculatum from the Manti-LaSal Mountains is noted.

Keywords: Bats, forests, survey, water.

\section{COMPARISON OF TECHNIQUES FOR MONITORING RIPARIAN BIRDS IN GRAND CANYON NATIONAL PARK}

\section{David L. Felley and Mark K. Sogge}

The construction of Glen Canyon Dam has had profound effects on the ecology of the riparian habitat of the Colorado River in Grand Canyon National Park. Future changes in water management will continue to affect this environment and long-term monitoring is needed to assess associated changes in riparian resources. We compared the results of point count surveys to walking surveys in these riparian habitats to test their usefulness for monitoring avian populations. Similar numbers of species were detected on walking and point count surveys. Our results show that 5-minute point counts are as reliable as walking surveys for detecting species occupying a site. Abundance estimates from point counts and walking surveys were highly correlated $(\mathrm{r}=0.98)$. Both point count surveys and walking surveys were effective at generating species lists and providing an index of abundance for birds using riparian habitats in the canyon. However, because the point count survey strictly controls survey effort and reduces 
observer variability, it is a more appropriate technique to monitor long-term trends in species composition and abundance for many species of riparian-breeding birds in the Grand Canyon. Keywords: Avian monitoring, Colorado River, point counts.

\section{CHARACTERISTICS OF MERRIAM'S TURKEY LOAFING HABITAT REUSED FOLLOWING SILVICULTURAL TREATMENT}

Brian F. Wakeling, Chris J. Mehling and Cheryl M. Mollohan

We monitored known turkey loafing sites following silvicultural treatment to determine which factors seem to influence habitat reuse. Five loafing sites used by Merriam's turkey (Meleagris gallopavo merriami) during the summer of 1989 on the Chevelon study area were protected from subsequent silvicultural treatment. Portions of the forest stands containing the loafing sites were logged in 1990. We inspected these loafing sites annually after logging to detect reuse by turkeys. Habitat surrounding two loafing sites was reused during summer 1992. Habitat characteristics of all five loafing sites were remeasured to determine characteristics that influenced reuse. Dense canopy, dense horizontal cover, and contiguous similar habitat were characteristics of loafing sites that received reuse following logging. Loafing habitat isolated from other similar habitat was not reused. Mosaic timber treatments that leave areas of $>25 \mathrm{~m} 2 /$ ha basal area (BA) and avoid isolation of habitats seem to favor turkey reuse. Keywords: Forest, habitat use, loafing, logging, Meleagris gallopavo merriami, Merriam's turkey, timber harvest.

\section{WINTER MOVEMENT PATTERNS OF MERRIAM'S TURKEYS IN NORTH-CENTRAL ARIZONA}

Brian F. Wakeling

I studied Merriam's turkey (Meleagris gallopavo merriami) movement patterns around roost sites in north-central Arizona during the winters of 1990-1991 through 1993-1994 to determine if distance from roost sites influenced habitat use. Knowledge of turkey movement patterns surrounding winter roosts would allow managers to predict potential adverse effects on habitat use from land management activities on winter range. I located 16 winter roost sites and 260 independent flock diurnal-use sites by visually locating radio-marked turkeys. Turkeys concentrated their diurnal use activities around roost sites, selecting areas $\leq 0.8 \mathrm{~km}$ from roost sites. Turkeys used habitat $>0.8 \mathrm{~km}$ and $\leq 1.6 \mathrm{~km}$ from roost sites proportionate with availability and avoided habitats $>1.6 \mathrm{~km}$ from roost sites. Land management activities $\leq 1.6 \mathrm{~km}$ from roost sites have the potential to impact wintering turkey populations. Efforts to increase suitable winter habitat for turkeys should include recruiting suitable roost sites within otherwise suitable habitat. Roost densities of $\geq 0.8$ per $\mathrm{km} 2$ seem optimal on winter turkey ranges.

Keywords: Habitat selection, habitat use, Meleagris gallopavo merriami, roost.

\section{ASSESSMENT OF CANOPY CLOSURE PROJECTIONS BY THE PROGNOSIS MODEL Dennis D. Haywood, Brian F. Wakeling and C. Richard Miller}

We studied the relationship between canopy closure derived from vertical projection and stand density index (SDI) during September 1993 on the Kaibab National Forest in northern Arizona to test predictions from the PROGNOSIS model. Management recommendations for wildlife species within southwestern ponderosa pine (Pinus ponderosa) forests frequently include desired canopy closures. Canopy closure estimates can be expensive to obtain beyond information collected during forest stand exams. Hence, foresters have developed models to predict canopy closure from existing data.

PROGNOSIS is a model that predicts canopy closure based on SDI; the model has not been validated in 
Arizona. We sampled 230 random plots across 10,000 ha to develop a data set for testing. The relationship between SDI and canopy closure explained less than $50 \%$ of the variation within the data set and PROGNOSIS consistently overestimated canopy closure when compared with estimates from vertical projection. By placing $95 \%$ confidence limits around the observed relationship between SDI and field measurements of canopy closure, we found PROGNOSIS estimates of canopy closure consistently outside the upper bounds of the relationship. PROGNOSIS should not be used in its current form to estimate canopy closure for wildlife habitat evaluations.

Keywords: Habitat evaluation, habitat model, SDI, stand density index, wildlife.

\section{DENDROCHRONOLOGICAL ANALYSIS OF GOODDING WILLOWS IN GRAND CANYON NATIONAL PARK} Joy Nystrom Mast and Gwendolyn Waring

In Grand Canyon National Park, dendroecological information on Goodding willow (Salix gooddingii) provided an estimate of the age structure of the population and the growth rate patterns. Goodding willow, a dominant riparian tree species before the construction of Glen Canyon dam, currently is at risk due to water flow regulation destroying habitat and competition with tamarisk (Tamarix chinensis). Lab analyses of annual rings revealed periods of growth suppression and release. The four chronologies (upper river, mid-river, lower river, and a control site) were created to help to examine climatic influence and river regulation impacts on willow growth. The age structure analyses showed a lack of Goodding willow recruitment at the upstream site of Lees Ferry and midstream site of Cardenas Creek. It appeared that the altered flood regime caused by Glen Canyon dam, as well as possibly the increase of tamarisk invaders, have adversely affected willow recruitment along the Colorado River up to the Lake Mead area. In contrast, classic J-shaped curves existed for the downstream site of Pearce Ferry near Lake Mead and the control side stream site of Diamond Creek, representing stable or expanding populations. The dendrochronological results of this study demonstrated impacts of Glen Canyon Dam flow regulation on the Goodding willow establishment and growth rate. Specifically, data showed the importance of flood events like the 1983 record post-dam flood to establishment of new stands of Goodding willows.

Keywords: Demography, flood control, Glen Canyon Dam, size structure, tree rings.

\section{AFTER 100 YEARS OF FOREST MANAGEMENT: "THE NORTH KAIBAB"}

\section{D. Garrett, M. H. Soulen and J. R. Ellenwood}

Assessment of 100 years of forest overstory data on the North Kaibab Ranger District reveals significant changes in overstory character and structure. Evaluation of early written observations by explorers, surveyors and naturalists indicate that tree densities of the 1850s were low and the forest floor had minimal fuel loads. Recent research in restoration ecology on the district indicates pre-European settlement tree densities were originally 30-60 trees per acre. Analyses of surveys completed in 1910, 1955, 1977, and 1993, reveal that tree densities below 6" diameter at breast height (dbh) have increased from 107 trees per acre in 1910 to over 900 today. Numbers of trees above $6 "$ dbh have increased from 45.3 trees per acre in 1910 to 115 in 1993. These increases have occurred with concurrent managed harvests of over 1.4 billion board feet of timber from the 1920s through 1994. Analysis of current conditions reveals $25 \%$ of the forest is potentially at high risk, and over $65 \%$ at potentially medium to high risk of ecosystem loss to insect and disease and/or wildfire. New ecosystem management guidelines, especially in regards to threatened and endangered species, could contribute to increased densities on the North Kaibab. 
Keywords: Ecosystem analysis, forest resource assessment, Geographic Information System, Kaibab National Forest, Pinus ponderosa, ponderosa pine, stand density index, tree densities.

\section{CHANGES FROM 1876 TO 1994 IN A FOREST ECOSYSTEM NEAR WALNUT CANYON, NORTHERN ARIZONA}

Jody P. Menzel and W. Wallace Covington

A central concept in adaptive ecosystem management is the use of the range of natural variability as a reference for developing and assessing management objectives and strategies. Using the range of variability as a reference requires that the conditions which prevailed prior to Euro-American settlement, which commenced in the mid to late 19th century in the West, be described and quantified. We used dendroecological techniques to estimate changes in forest structure since Euro-American disruption of the natural disturbance regime in a Pinus ponderosa-Quercus gambelii woodland on the northern rim of Walnut Canyon in northern Arizona. The reconstruction of the 1876 stand structure showed an increase in density of trees greater than $10 \mathrm{~cm}$ diameter at breast height (dbh), or greater than $10 \mathrm{~cm}$ diameter at root collar (drc) for nontimber species, from $72 \mathrm{stems} / \mathrm{ha}$ in 1876 to $333 \mathrm{stems} / \mathrm{ha}$ in 1994. Total basal area for trees larger than $10 \mathrm{~cm}$ increased from $9.0 \mathrm{~m} 2 / \mathrm{ha}$ in 1876 to $19.1 \mathrm{~m} 2 / \mathrm{ha}$ in 1994, primarily due to a greater number of trees in smaller size classes. Overstory composition also changed since 1876. At that time Pinus ponderosa stems represented an estimated $80 \%$ of the basal area of all trees larger than $10 \mathrm{~cm}$, a proportion which decreased to 68\% in 1994. Quercus gambelii increased from less than 5\% of total basal area in 1876 to over $15 \%$ in 1994, Pinus edulis increased from $2.5 \%$ to nearly $5 \%$, and Juniperus spp. increased from $12.7 \%$ to $15 \%$.

Changes in forest structure associated with Euro-American settlement previously have been documented in pure and mixed western pine ecosystems. Results from the Walnut Canyon area demonstrate that similar changes also occurred on marginally productive limestone soils near and within the ecotone between ponderosa pine forests and pinyon-juniper woodlands.

Keywords: Ecosystem management, Euro-American settlement, fire suppression, pine-oak woodland, presettlement, range of natural variability.

\section{THE KNOWLES CAÑON HANGING GARDEN, GLEN CANYON NATIONAL RECREATION AREA, FIVE YEARS AFTER BURNING: VEGETATION AND SOIL BIOTA PATTERNS Tim B. Graham}

Hanging garden plant communities form at seeps on cliffs. A given community may include common riparian species, disjunct populations, and species endemic to hanging gardens. What structures hanging garden communities, and how they respond to disturbance are poorly understood. In 1989, fireworks ignited a hanging garden in Knowles Cañon, destroying aboveground vegetation. Permanent plots were established in July 1993 to monitor changes in vegetation and soil biota. Revegetation of the garden has been limited to grasses, forbs, and ferns where water was present at the soil surface, and shrubs and trees sprouting from surviving rootstocks. Water drips from the overhanging cliffs in the central area, where plant cover is almost $100 \%$. Both moisture and vegetation were patchy along the backwall. The soil was dry in most of the alcove and remained unvegetated 5 years after the fire. Central area soils had more fungus than bacteria and contained mostly root-feeding nematodes. Backwall soils contained more bacteria than fungi, and mostly bacteriovore nematodes. The dry areas had little active bacteria or fungi and few nematodes.

Keywords: Colorado Plateau, fire, Glen Canyon NRA, hanging garden, soil bacteria, soil fungi, soil nematodes, succession. 


\section{INTEGRATION OF GRAND CANYON PHYSICAL AND BIOLOGICAL INFORMATION: A PROGRESS REPORT}

Vicky J. Meretsky and Theodore S. Melis

Ecosystem management of regulated rivers requires not only integration of different kinds of data, but also effective communication between researchers and managers. We report on recent efforts to improve both processes in lower Colorado River ecosystems of Grand Canyon. Between 1989 and 1995, the Bureau of Reclamation and its cooperators conducted Phase II of the Glen Canyon Environmental Studies to supplement earlier (Phase I) scientific river-based research in Grand Canyon, and produce an environmental impact statement on Glen Canyon Dam operations. Phase II studies were designed to provide "an integrated approach to studying and understanding the relationships between the operations of Glen Canyon Dam and the ecological components of Grand Canyon." By the end of Phase II environmental impact studies, researchers had identified linkages between their own databases and other studies, and opportunities to integrate research were numerous. For example, geomorphology reports contained information relevant to understanding habitat availability for humpback chub. To facilitate integration, the Bureau of Reclamation convened a meeting of Grand Canyon researchers in August 1995. The goal of the meeting was to solicit input on strategies for future integration of abiotic and biotic information. Meeting discussions focused on scientific questions relating to endangered species issues that are best addressed through integrated analyses. Other discussions revolved around the meaning of the term "adaptive management" from a scientific perspective, and the role of science in environmental management. We present an abridged history of past research under the Glen Canyon Environmental Studies program, summarize the results of this first integration meeting, and outline an approach to future integration of physical and biological analyses to improve ecosystem management. Keywords: Adaptive management, biological opinion, ecosystem management, environmental impact statement, integrated management.

\section{EVIDENCE FOR DEEP WATER DEPOSITION OF THE TAPEATS SANDSTONE, GRAND CANYON, ARIZONA \\ Elaine G. Kennedy, Ray Kablanow and Arthur V. Chadwick}

The Tapeats Sandstone forms the basal Cambrian deposit of the Tonto Group and is generally interpreted as a shallow marine deposit. In the Grand Canyon, the sandstone was deposited on a lowrelief pre-Cambrian surface broken by scattered remnant cliffs of Shinumo Quartzite and isolated granitic hills. Paleoslope measurements and sedimentological features were recorded at 63 sections from 21 localities in the Grand Canyon exhibiting significant pre-Cambrian topographic relief. At 24 of these sites, debris flows were apparently initiated by some catastrophic event that simultaneously broke and transported Shinumo clasts in a matrix of Tapeats Sandstone. These brecciated flows were deposited along the pre-Cambrian surface topography from the cliff-faces basinward. Widespread preservation of the breccias along topographic relief during the deposition of the entire thickness of Tapeats Sandstone and much of the overlying Bright Angel Shale indicates that deposition of even the shallowest material was below storm wave base. Thorium/uranium $(\mathrm{Th} / \mathrm{U})$ ratios from the breccia matrix in Ninety-one Mile Canyon indicate sediment deposition in a reducing environment. Such conditions are unlikely in a highenergy, nearshore facies. These submarine flows were deposited on a surface with over $140 \mathrm{~m}$ of vertical relief and would have required water depths in excess of $200 \mathrm{~m}$ below storm wave base. Sedimentary structures used to identify the Tapeats Sandstone as a shallow water marine facies need to be reevaluated. To explain the features documented in this research, we propose that the Tapeats Sandstone was deposited as a deep-water, submarine fan complex. 
Keywords: Breccia, Cambrian, deep water, monadnocks, Ninety-one Mile Canyon, Shinumo quartzite, trace elements.

\section{PRELIMINARY RESULTS OF NOISE MONITORING IN 1995 IN BRYCE CANYON NATIONAL} PARK

Dan A. Foster and Richard M. Bryant

Staff at Bryce Canyon National Park conducted noise monitoring surveys from 30 May to 31 August 1995 at five sites using the 15 -second Leq method. Noise levels from helicopters, planes, jets, and other mechanical means, as well as natural or background noise were monitored. Aircraft were heard park-wide an average $18.8 \%$ of the time with an average of 36.4 decibels. Site-specific information is presented on peak decibel levels, average noise levels, and number of aircraft overflights. Keywords: Aircraft, monitoring, noise, overflight.

\section{PREHISTORIC AGRICULTURE AT HIGH ALTITUDE ON THE NORTHERN COLORADO}

\section{PLATEAU}

\section{William B. Fawcett and Jason R. Bright}

Archaeological investigations east of Moab, Utah have revealed an ancient agricultural field with linear water control features at a high elevation (7,500 feet). Excavation in a nearby cave, believed to be associated with the use of this agricultural field, recovered many diverse cultigens in fine stratigraphic contexts. We believe these deposits date from the last half of the first millennium A.D. Human occupations of the cave were consistently brief and ephemeral. Human subsistence varied between the extremes of full reliance on wild species and heavy use of domesticated cultigens.

Keywords: American southwest, Anasazi, egalitarian, Fremont, horticulture, hunter-gatherers, mobility, Pueblo. 
Proceedings of the Third Biennial Conference

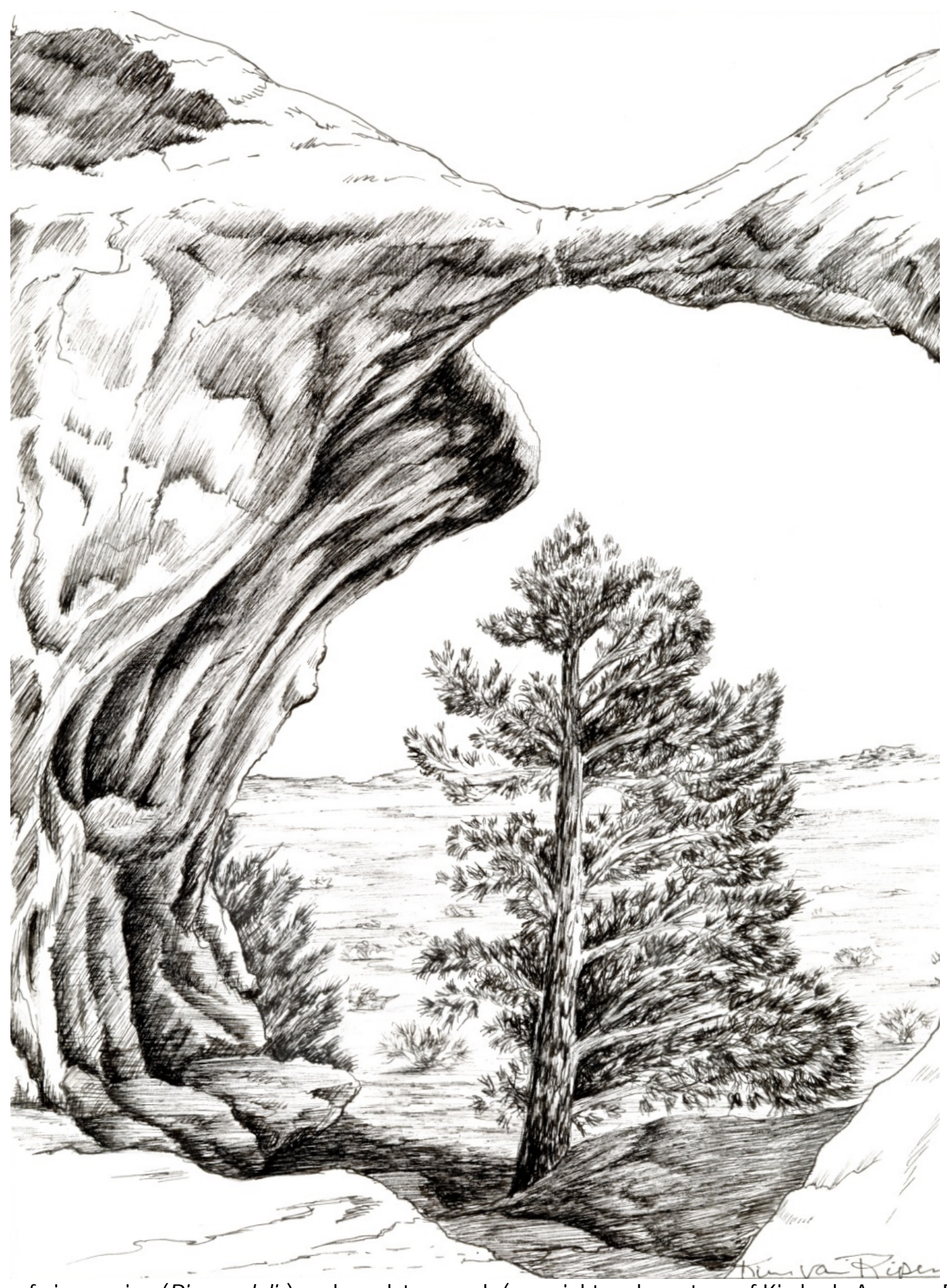

Drawing of pinyon pine (Pinus edulis) and sandstone arch (copyright and courtesy of Kimberly Ann van Riper). 


\title{
Proceedings of the Fourth Biennial Conference of Research on the Colorado Plateau
}

\author{
Edited by Charles van Riper III and Maureen A. Stuart
}

The 13 chapters in this book were selected from the 75 research papers presented at the Fourth Biennial Conference of Research on the Colorado Plateau. The theme of this meeting centered around research, inventory, and monitoring on lands over the Colorado Plateau, with a focus on the newly created BLM Grand Staircase-Escalante National Monument. The conference, held on 15-18 September 1997 in Flagstaff, Arizona, was hosted by the USGS Forest and Rangeland Ecosystem Science Center Colorado Plateau Field Station (CPFS) and Northern Arizona University.

This is the fourth volume in a planned series of Colorado Plateau Proceedings, highlighting research and resource management efforts related to physical, cultural and natural resources within the biogeographic province of the Colorado Plateau. Many of the protocols and management techniques presently being utilized in land management units over the Colorado Plateau are a result of collaborative work between CPFS staff, university and agency scientists, and land managers. The scientific work published in this Proceedings Series contributes significantly to those collaborative efforts. It has been clearly demonstrated that, because of similarities across the Colorado Plateau, techniques that work in one management unit are applicable to other units throughout the province, and possibly to other areas of the country that have similar habitat and climatological parameters.

Each paper selected for publication in this Proceedings represents original research and has been peer reviewed by scientists of that particular research discipline. The papers are divided into two major sections: I. those that deal with Biological Resources; and, II. those addressing Cultural Resources. The Biological Resources section comprises the first 9 chapters of this book, with the first three chapters dealing with vegetation and the next six with studies of animal ecology. The final four chapters fall under Cultural Resources, evenly divided between archeology and policy chapters pertaining to human perceptions of managing cultural resources.

\section{Biological Resources}

It is fitting to begin this section, and in particular the book, with a chapter dealing with a unique aspect of the Colorado Plateau. The paper by Cole and Murray describes Holocene vegetation of Capitol Reef National Park from packrat midden analyses. Fossil packrat middens are valuable sources of paleoecological information in arid regions of the southwest. On the Colorado Plateau, information on pre-settlement vegetation is often lacking, and analyses of packrat middens allow researchers to reconstruct these earlier vegetation communities. Such was the objective of this first paper, in that Capitol Reef National Park needed a baseline of vegetation community information from which to construct restoration guidelines. Information from packrat middens allowed Cole and Murray to demonstrate that the present vegetation community is apparently an artifact of overgrazing. The chapter clearly documents that vegetation species lost since pre-settlement were those that were more palatable to large herbivores. In fact, the authors argue that in their reconstruction of vegetation communities, some species reached their lowest levels in the past 5,400 years. Conversely, species typical of presentday overgrazed ranges on the Colorado Plateau, were not present in the earlier packrat midden record. The authors also feel that the increase in Utah juniper (Juniperus osteosperma) pollen in their midden 
records over the past 200 years has probably been a result of fire suppression at Capitol Reef National Park.

The second chapter of the Biological Resources section also examines vegetation changes, but in this instance switches time-frames, examining only historical forest structure. Garrett and Soulen provide an analysis of the changing overstory density of the Apache/Sitgreaves National Forest in eastern Arizona. They examine tree-density data from surveys in 1911, 1967, 1988 and 1994, concluding that the density of trees per acre has increased dramatically in all size classes up to $20 " \mathrm{dbh}$. Computer simulated treatments utilizing analyses with a Geographic Information System, revealed that agencies would realize enhanced positive values if tree densities in the forests were brought into line with pre-settlement conditions.

The final vegetation chapter by Floyd-Hanna et al. deals with vegetation response to fire at Mesa Verde National Park. The authors document their efforts at monitoring vegetation response and mitigation to the lightning-initiated 'Chapin 5' fire in August 1996. The 4,781 burned acres were divided into 7 pre-fire vegetation communities and 2 principal geological substrates for monitoring purposes, Subsets of these 9 areas were monitored, and either aerially seeded or had mechanical removal of alien plant species. The authors demonstrated multiple pathways of native vegetation recovery from the 1996 fire, but also feel that in certain areas alien plants now dominate the landscape and are preventing the recovery of native vegetation communities. This will certainly present a challenge to the 'noxious weed' initiative of Mesa Verde National Park.

Chapter \#4 of the Biological Resources section provides a transition into wildlife management, where Wakeling et al. examine the performance of aerial forward-looking infrared (FLIR) surveys on cattle, elk, and turkeys in the forests of northern Arizona. Wildlife managers are often challenged by techniques needed to determine total numbers of animals, whether it be for carrying capacity or in order to set hunting season bag limits. Aerial FLIR surveys became popular because they seemed to standardize and objectively survey large wildlife species without bias. Wakeling et al. conducted FLIR tests on known number of cattle, known turkey roosts, and known locations of elk herds using replications with fixed wing aircraft and then helicopters. Their findings demonstrate that FLIR is not yet suitable for small animals such as turkeys, and that not all large animals are observed. The authors recommend against the use of FLIR as a sole estimate of large-bodied wildlife species in Arizona, until correction factors for target species, timing, and habitat can be developed.

In the next chapter, Sisk et al. provide a unique insight into how they have developed a 'management team' approach to shape an experimental research program that examines the livestock grazing debate on the Colorado Plateau, The authors base their chapter on the assumption that domestic livestock grazing is the most pervasive human impact on lands of the Colorado Plateau. In fact, ranching versus environmental interests have made livestock grazing the most contentious issue in the southwestern United States. The authors feel that this polarization of interests has come about because there is a lack of scientifically sound, defensible information to support either side of the issue. Sisk et al. provide a plan of action where they take the claims of each interest group, reformulate these claims into testable hypotheses, and then provide research designs for each of the hypotheses. This chapter exemplifies a modern-day approach on how science must deal with volatile social issues, if there is ever to be any hope of bringing disparate groups together so that a solution can be reached which is acceptable to all parties.

Chapters \#6 and \#7 move into radio telemetry studies that examine behavior of mammals. Lema et al. examine the social behavior of Abert's squirrels (Sciurus aberti) in Chapter \#6, presenting the results of a 12 month study on radio-collared squirrels near Flagstaff, Arizona. They demonstrate, for the first time, that this species exhibits extensive social behavior. According to the authors, it was 
previously believed that Abert's squirrels were solitary animals. Lema et al. found pairs and trios of squirrels occupying communal nests that included male/female and male/male combinations of varying age classes. They also found, in over half their observations, that more than one Abert's squirrel occupied a tree. The authors conclude this chapter suggesting that communal nesting behavior among Abert's squirrels may facilitate thermoregulation, and that this type of nesting and tree sharing may reinforce social bonding and resource sharing. In Chapter \#7, Siders et al. examine foraging distances of two uncommon bat species on the Kaibab Plateau in northern Arizona. This radio telemetry study determined the foraging areas of seven lactating female spotted bats (Euderma maculatum), documenting daily movements of up to $42 \mathrm{~km}$. It appears that although the bats forage in locations at $2500 \mathrm{~m}$ elevation, they prefer to day roost at lower elevations (e.g., approximately $1000 \mathrm{~m}$ elevation). The authors also provide information on maternity roosts and relative numbers of 18 bat species captured from between 1994 and 1998.

The final two biological chapters deal with studies of Merriam's turkeys. In Chapter \#8 Wakeling and Goodwin examine over-winter survival of turkeys in the North Kaibab region of Arizona. During 1996, several severe fires occurred on the Kaibab Plateau, and the authors wanted to examine, with radio-collared birds, the potential influence of these fires on over-winter survival. They found significantly higher mortality in this area of Arizona in 1996 when compared to other regions of the state. First-year birds were more greatly affected, with a mortality rate of $90 \%$ versus $34 \%$ in adult females. All cohorts of turkeys experienced the greatest mortality between January and March, and the authors attribute the increased mortality to deep snow and limited food availability. This study supports the contention that winter food availability is closely tied with turkey over-winter mortality. In the last chapter of the Biological Resources section, Rogers et al. examine the impact of U.S. Forest Service transportation corridors on male turkey distributions. The authors found that turkeys avoided locations less than $200 \mathrm{~m}$ from roads, for all resightings and for all roost sites. However, improved high-traffic roads had a much greater negative influence than did unimproved, low-traffic roads. They were not able to ascertain what level of road use that turkeys found unacceptable.

\section{Cultural Resources}

Chapter \#10 begins the Cultural Resources section of this book, with a study by Fawcett and Latady on an archeological survey of Black Ledge, a mesa immediately adjacent to Coombs site, the largest ancestral pueblo village in south-central Utah. The authors use archeological data from Black

Ledge (principally lithic artifacts and site settings) to examine potential reasons for a prehistoric shift from formal (bifacial) technology to expedient (core) technology. In other words, they examined the question of why nomadic people of the Colorado Plateau settled into a more sedentary style of living. The theme of this chapter is the comparison of Late Archaic sites of mobile hunter-gathers with the equally ephemeral sites created largely by women, as they harvested, processed and transported wild resources for use during the Late Formative period. Fawcett and Latady conclude that their survey data support the same shift in organization of prehistoric lithic technology (from bifaces to cores) on the Colorado Plateau, that has been observed in many other places throughout the southwestern United States and around the world.

An archeological survey of Cedar Breaks National Monument in southern Utah, is the theme of Chapter \#11. Canaday et al. subdivide their survey work at Cedar Breaks into two discrete locations of the Markagunt Plateau: those areas below 9,200 feet and those above 10,000 feet elevation. They found little prehistoric use in the lower site, but demonstrated extensive use of the higher elevations over the past 4,000 years. Procurement of chert from the Brian Head Formation for hunting purposes appears to have been the primary activity. The authors have also initiated a number of ancillary studies, such as 
trace mineral analyses and palynological (pollen) studies from a peat bog, to provide a better understanding of prehistoric use of Cedar Breaks and the Markagunt Plateau.

Chapter \#12 provides a transition from purely archeological studies to human policy surrounding cultural resources. Balsom summarizes the benefits and drawbacks of the Spring 1996 'Experimental Habitat Building Flow' in Grand and Glen Canyons. In particular the potential loss/preservation of cultural resources from higher water volume releases of Glen Canyon Dam is examined. From 45 previously recorded sites, four were chosen to measure potential impacts on archeological resources. The author's overall conclusion was, with a few cautions, that habitat building flows were beneficial to the cultural resources along the Colorado River in Grand and Glen Canyon National Parks.

The final chapter of the Fourth Biennial Conference Proceedings is that of Nie, who examines the debate over establishment of wilderness in Utah, and particularly the Grand Staircase-Escalante National Monument. Through a number of personal interviews and a compilation of newspaper articles and federal legislation, the author weaves a complex picture surrounding the debate over Southern Utah Wilderness and how this fits into the framework of the 'true' West. It is apparent from this treatise that issues on the southern Colorado Plateau, and in particular Utah, transcend solely environmental protection, to a plethora of regional-specific themes and concerns. Nie argues that placing the debate only in terms of wilderness acreage is overly simplistic, and that one has to examine more closely the values of the local residents and focus on culture and place. It is only once these dimensions of cultural values are included in the equation, can the wilderness debate on the Colorado Plateau be understood and the conflict diminished.

\section{Abstracts}

\section{MIDDLE AND LATE HOLOCENE PACKRAT MIDDENS FROM CAPITOL REEF NATIONAL}

\section{PARK}

Kenneth L. Cole and Lyndon K. Murray

Twenty Holocene and two late Wisconsinan packrat middens were collected and analyzed from Capitol Reef National Park. The two older middens, collected at $1390 \mathrm{~m}$ elevation, were greater than 26,000 years in age and contained species typical of much higher elevations, such as Douglas fir, limber pine, Rocky Mountain juniper, and Knowlton hophornbeam. These ancient middens demonstrate the antiquity of many inaccessible deposits high in the Navajo Sandstone.

Nine Holocene middens were collected from Hall's Canyon, eight from the Hartnet Draw area, and three from other locations. A comparison of the middle and late Holocene middens to five modern middens and to modern vegetation suggest that vegetation changes taking place in the last several hundred years are more extreme than any changes occurring since at least the middle Holocene. The nature and timing of these changes imply that they were primarily caused by nineteenth century openland sheep grazing.

Presettlement middens consistently contained abundant macrofossils of plant species palatable to large herbivores that are now absent or reduced, such as winterfat (Ceratoides lanata) and ricegrass (Stipa hymenoides), especially in the most complete series at Hartnet Draw. Macrofossils and pollen of pinyon pine (Pinus edulis), sagebrush (Artemisia spp.) and roundleaf buffaloberry (Shepherdia rotundifolia) were also recently reduced to their lowest levels for the 5400 year record. Conversely, species typical of overgrazed range, such as snakeweed (Gutierrezia sarothrae), viscid rabbitbrush (Chrysothamnus viscidiflorus), and Russian thistle (Salsola sp.) were not recorded prior to the historic introduction of grazing animals. Pollen of Utah juniper (Juniperus osteosperma) also increased during the last 200 years, possibly due to the elimination of grassland fires. 
Keywords: Holocene vegetation history, grazing impacts, packrat middens, fossil pollen, presettlement vegetation

\section{CHANGES IN CHARACTER AND STRUCTURE OF APACHE/SITGREAVES FOREST ECOLOGY: 1850-1990}

\section{D. Garrett and M. H. Soulen}

This analysis of the Apache/Sitgreaves National Forest in eastern Arizona was undertaken to evaluate changing ponderosa pine (Pinus ponderosa) overstory tree densities and their potential environmental and economic impacts. Assessment of 100 years of forest overstory data on the Apache/Sitgreaves reveals significant change in overstory character and structure. Evaluation of early written observations by explorers, surveyors and naturalists indicate that tree densities of the $1850 \mathrm{~s}$ were low, and the forest floor had minimal fuel loads. Recent research on the Forest indicates pre-European settlement tree densities were originally as low as 34 trees per acre above $4 " \mathrm{dbh}$. Analysis of surveys completed in 1911, 1967, 1988, and 1994 reveals that the number of trees per acre in ponderosa pine type has increased significantly from approximately 34 trees per acre above 4 " dbh in 1911, to 133 trees per acre above 4" dbh in 1994. Tree density increases have occurred in all diameter classes up to 20" $\mathrm{dbh}$. The analysis determined that approximately 21 trees existed in these classes in 1911 and over 127 trees exist today. This represents a 500 percent increase in tree densities between 4" and 20" dbh over the century. The analysis also determined that of the average of 13 trees per acre above 20" dbh in 1911, 7 exist today, a loss of approximately $50 \%$. Computer simulated treatments to the forest overstory that approach presettlement conditions reveal significant enhancement of forest ecosystem resources as compared to no treatment alternatives. Further, implementation of restoration treatments would realize positive net present values from public investments.

Keywords: Forest ecosystem impacts, presettlement, fire suppression, forest resource assessment, tree densities, stand density index, economic evaluation

\section{CHAPIN 5 FIRE VEGETATION MONITORING AND MITIGATION}

\section{Lisa Floyd-Hanna, Anne DaVega, David Hanna and William H. Romme}

The Chapin 5 Fire ignited on 17 August 1996, burning 4,781 acres of Mesa Verde National Park. With Burn Area Emergency Rehabilitation (BAER) funding, we are (1) evaluating residual vegetation, (2) monitoring post-fire native plant recovery, and (3) treating non-native plant invasion. To evaluate residual seeds and grass rootstocks, we developed an effective test using the physical strength of the remaining bunch grasses, the "pull test." Residual vegetation was low; grass frequency (average=.52) was reduced (average $=.18$ ) after the fire $(\mathrm{t}=7.3, \mathrm{P}<.05)$ and few species germinated or re-sprouted in 1996. Vegetation recovery is being monitored at 75 points randomly placed in 20 habitat types defined in a GIS environment. By August 1997, 210 vascular plant species occurred in the burn area. Firefacilitated species include Gayophytum ramosissimum, Nicotiana attenuata and Collomia grandiflora. Re-sprouting shrubs account $41-60 \%$ of the vegetative cover in the mountain shrubland habitats. The intensely burned piñon-juniper habitats support $23-40 \%$ forb cover, $14-40 \%$ grass cover and bare soils are common. Non-native species are aggressively invading bare soil as well as previously disturbed areas. An integrated pest management approach — seeding native grasses, mechanical removal, herbicide spot-spraying, and 5 biological control agents - is being used to prevent the spread of non-native species.

Keywords: wildfire, Mesa Verde National Park, non-native species, monitoring, mitigation, Colorado. 
PERFORMANCE OF AERIAL FORWARD-LOOKING INFRARED SURVEYS ON CATTLE, ELK, AND TURKEY IN NORTHERN ARIZONA

\section{Brian F Wakeling, David N. Cagle and James H. Witham}

We conducted performance tests of aerial forward-looking infrared (FLIR) technology to assess its capability to survey cattle, elk (Cervus elaphus), and Merriam's turkey (Meleagris gallopavo merriami) in forested habitat. Fixed-wing FLIR surveys of known numbers of cattle were inaccurate, but linear correlations explained $86 \%$ of the variation, and initial estimates could be corrected to provide accurate estimates. We observed no relationship among fixed-wing FLIR, helicopter FLIR, and visual fixed-wing surveys for elk. In three attempts, we were unable to detect roosting turkeys in night-time aerial, fixed-wing FLIR overflights. FLIR surveys seem to be capable of quantifying large-bodied wildlife, but corrections for sightability need to be developed for each species, season, and habitat that will be surveyed. This correction will probably require several populations of known number to evaluate. Small-bodied wildlife may prove problematic. We recommend against the use of aerial FLIR surveys as the sole estimate of large-bodied wildlife species until correction factors can be developed. Keywords: Arizona, cattle, Cervus elaphus, elk, FLIR, infrared, Meleagris gallopavo merriami, Merriam's turkey, survey.

\section{ASSESSING IMPACTS OF ALTERNATIVE LIVESTOCK MANAGEMENT PRACTICES:} RAGING DEBATES AND A ROLE FOR SCIENCE

Thomas D. Sisk, Timothy E. Crews, Ryan T. Eisfeldt, Matthew King and Elaine Stanley

Grazing of domestic livestock is the most pervasive and persistent human impact on the grasslands and shrublands of the Colorado Plateau. Impacts on ecosystem function and biological diversity are thought to be great, but few studies have attempted to characterize such effects and compare the impacts of alternative livestock management practices. The dearth of pertinent, defensible information has contributed to the polarization of ranching and environmental interests, and has exacerbated what is one of the most contentious social issues in the southwestern USA. We discuss the role of ecological science in deriving and disseminating information that will help focus and perhaps resolve the impasse over grazing impacts and other natural resource issues. Specifically, we describe results of our involvement in "management teams" that include ranchers, environmentalists, public servants, and interested citizens, and how this collaborative process has helped shape an experimental research program that would be impossible to execute without the involvement of divergent interests in the grazing debate. Claims of various interest groups are reformulated as testable hypotheses, and a research design is presented.

Keywords: arthropods, biological diversity, conflict resolution, cooperative research, plant communities, grazing, net primary productivity, ranching.

\section{SOCIAL BEHAVIOR OF ABERT'S SQUIRRELS IN PONDEROSA PINE FORESTS} Melissa F. Lema, W. Sylvester Allred, William S. Gaud and Norris L. Dodd

During an ongoing 12 month radio-telemetry study, apparent social behavior was observed in Abert's squirrels (Sciurus aberti aberti) at two study sites near Flagstaff, Arizona. Although considered mostly a solitary species, approximately $53 \%$ of the radio-collared squirrels $(n=28)$ exhibited communal nesting behavior at least once during the period from November 1996 through early May 1997. The pairs and trios of squirrels occupying communal nests included male/male combinations and male/female combinations. Furthermore, nest sharing occurred between both squirrels of the same age class (adult/adult, juvenile/juvenile) and squirrels of different age classes (adult/juvenile). Tree sharing behavior was also observed among the squirrels. Approximately 59\% of the radio-collared squirrels 
$(n=32)$ were visually located in a ponderosa pine (Pinus ponderosa) concurrently occupied by one or more squirrels at least once during the course of the study. Communal nesting behavior among Abert's squirrels may facilitate thermoregulation, and both communal nesting and tree sharing may reinforce social bonding and resource sharing.

Keywords: Abert's squirrel, communal nesting, tree sharing, thermoregulation, social bonding

\section{LONG FORAGING DISTANCES IN TWO UNCOMMON BAT SPECIES (EUDERMA MACULATUM AND EUMOPS PEROTIS) IN NORTHERN ARIZONA \\ Melissa S. Siders, Michael J. Rabe, Tim K. Snow and Kei Yasuda}

The Kaibab Plateau of north-central Arizona is a high elevation, limestone plateau on the northern edge of the Grand Canyon. We used radio telemetry to determine foraging areas for seven lactating female spotted bats (Euderma maculatum) and located roosts for four of these bats. We also captured greater western mastiff bats (Eumops perotis) and located a single roost for this species. Roosts for both spotted and mastiff bats were in xeric cliffs in or near Grand Canyon National Park (GCNP) at approximately 650 to $1040 \mathrm{~m}$ elevation. Distances from capture location to maternity roosts ranged from approximately 28 to $42 \mathrm{~km}$. Capture sites and foraging areas were located at approximately 2600 $\mathrm{m}$ elevation for spotted bats and $1900 \mathrm{~m}$ for mastiff bats. We caught 18 bat species during mist net surveys conducted from 1994 through 1998. The high species diversity that we observed may be due to the proximity of the Kaibab Plateau to the Grand Canyon, and the great range of elevations and habitats available from the floor of GCNP (600 m elevation, desert) to the meadows (2600 $\mathrm{m}$ elevation, subalpine) on the Kaibab Plateau.

Keywords: foraging, western mastiff bats, Eumops perotis, spotted bats, Euderma maculatum, Kaibab Plateau, Arizona, Grand Canyon National Park, surveys

\section{MERRIAM'S TURKEY WINTER SURVIVAL ON THE NORTH KAIBAB RANGER DISTRICT FOLLOWING THE BRIDGER KNOLL COMPLEX WILDFIRES \\ Brian F. Wakeling and John G. Goodwin, Jr.}

During the winter of 1996-1997, we studied the survival of 34 radio-marked Merriam's turkeys (Meleagris gallopavo merriami) on the North Kaibab Ranger District (NKRD) of the Kaibab National Forest following the Bridger Knoll complex wildfires. We studied these turkeys because food availability seemed limited and the fires had substantially altered part of the traditional turkey winter range. During winter 1996-97, adult female turkeys from NKRD had lower $(\mathrm{P}<0.001)$ body weights at capture than those from other Arizona habitats. Adult female over-winter survival was greater $(\mathrm{Z}=$ 3.901, $\mathrm{P}<0.001$ ) than survival of subadult turkeys, but did not differ from mean adult female turkey over-winter survival in north-central Arizona $(Z=0.861, P>0.195)$. On the NKRD, subadult turkeys experienced $10.4 \%$ over-winter survival while adult females experienced $66.2 \%$ over-winter survival. Turkeys experienced the greatest mortality during late January and throughout March, generally in conjunction with adverse weather conditions and increased snowfall. Limited food availability and deep snow negatively influenced turkey survival. Although this study was prompted by concerns about the wildfire effects on the NKRD, we believe that limited winter food availability would have resulted in depressed survival rates even if the wildfires had not occurred. Our study supports the contention that winter food availability is closely tied with turkey over-winter survival.

Keywords: Arizona, food, Meleagris gallopavo merriami, Merriam's turkey, mortality, survival, winter 
MERRIAM'S TURKEY DISTRIBUTION IN RELATION TO THE U.S. FOREST SERVICE RECREATIONAL OPPORTUNITY SPECTRUM FOREST CLASSIFICATION AND ROAD PROXIMITY IN NORTH-CENTRAL ARIZONA

Timothy D. Rogers, Brian F. Wakeling, Susan R. Boe

We studied male Merriam's turkey (Meleagris gallopavo merriami) summer distribution in relation to the U.S. Forest Service Recreational Opportunity Spectrum (ROS) habitat classifications and road proximity to determine if the potential indices of disturbance influenced turkey habitat and roost site use. The ROS habitat classification proved of limited use, but turkeys avoided habitats $<200 \mathrm{~m}$ from roads for both total locations and roost site locations. Improved high-traffic roads seem to negatively influence turkey habitat use, although turkeys were often found in association with unimproved, lowtraffic roads. We did not ascertain what level of road use turkeys found unacceptable.

Keywords: Arizona, disturbance, habitat, Meleagris gallopavo merriami, Merriam's turkey, roads, ROS

CHANGES IN THE ORGANIZATION OF TECHNOLOGY AND LABOR AMONG ARCHAIC AND ANCESTRAL PUEBLO PEOPLES IN THE VICINITY OF THE COOMBS SITE, SOUTHCENTRAL UTAH

William B. Fawcett, Jr. and William R. Latady

Archeologists have proposed alternative explanations (decreased mobility, risk avoidance, adoption of agriculture, sexual division of labor) to account for the shift from formal (bifacial) technology to expedient (core) technology. We examine these alternatives through an analysis of lithic artifacts and site settings documented through an archeological survey of Black Ledge - a mesa immediately adjacent to the Coombs site, the largest ancestral pueblo village in south-central Utah. We contrast the sites associated with more mobile hunter-gatherers during the Late Archaic, to the equally ephemeral sites created largely by women as they harvested, processed, and transported wild resources for use in their Late Formative village at Coombs.

Keywords: archeology, Utah, Coombs site, Black Ledge, lithic artifacts, Late Archaic, Late Formative

\section{RECENT HIGH ALTITUDE ARCHEOLOGICAL SURVEYS AT CEDAR BREAKS NATIONAL} MONUMENT, UTAH

Timothy W. Canaday, Matthew J. Betenson and Laird P. Naylor II

The cultural history of southern Utah's Markagunt Plateau is not well known, but recent archeological surveys have focused on the identification and interpretation of cultural resources within Cedar Breaks National Monument. We conducted survey work in two discrete areas: (1) the lower portions of the monument at elevations ranging from 7,800 to 9,200 feet (2,377 to $2804 \mathrm{~m}$ ); and (2) at higher elevations ranging from 10,100 to $10,600 \mathrm{ft}$. (3,078 to 3,230 m). The lower survey areas were found to contain very few archeological resources while the upper portions of the monument were heavily utilized by prehistoric people for at least 3-4,000 years and perhaps longer. Procurement of chert from the Brian Head Formation appears to have been a primary activity. In addition to the archeological investigation, ancillary studies were initiated, including petrographic and trace mineral analysis of chert source, obsidian sourcing, palynological studies of area peat bogs, and dendroclimatic studies. These ancillary studies will enable a better understanding of prehistoric land use on the Markagunt Plateau, and specifically at Cedar Breaks National Monument.

Keywords: cultural resources, Archaic, Late Prehistoric, lithic scatters, chert quarries, paleoenvironment, Cedar Breaks National Monument, Markagunt Plateau 


\section{CULTURAL RESOURCES AND THE GLEN CANYON DAM-COLORADO RIVER} EXPERIMENTAL FLOW OF 1996

\section{Janet Balsom}

The Bureau of Reclamation conducted an experimental flow from Glen Canyon Dam in late March and early April of 1996. The flow reached a maximum of 45,000 cfs and was expected to provide system-wide mitigation to most cultural sites in the river corridor through the accumulation of more sediment. A positive effect was presumed, but not guaranteed. Monitoring in the years prior to the experimental flow determined that a possible negative impact could result at eight archeological sites along the river corridor between Glen Canyon Dam and Lake Mead. On-site mitigation was required at these locations to fulfill federal agency responsibilities for any impacts sustained as a result of the proposed experimental flow. In addition to the required mitigation, monitoring of archeological sites and other kinds of cultural resources, ethnobotanical resources, beaches, and sediment accumulation at the mouths of arroyos was undertaken to assess the results of the experimental flow. Terraces were studied in the Glen Canyon Reach to determine whether terrace erosion in this area occurred as a result of the experimental flow. This paper summarizes the results of the coordinated mitigation and monitoring of cultural resources and sediments in the area of potential effect of the 1996 experimental habitat building flow from Glen Canyon Dam.

Keywords: archeology, Glen Canyon Dam, Colorado River, American Indian Tribes, geomorphology, ethnobotany

\section{SOUTHERN UTAH WILDERNESS AND THE MEANING OF THE WEST}

\section{Martin A. Nie}

The debate over Southern Utah wilderness and the more recent Grand Staircase-Escalante National Monument designation transcends issues of environmental protection to include a host of regional-specific themes and concerns. Cultural contours and cleavages such as a rural Western economy and federal versus de jure wilderness, have framed the Utah wilderness debate. These cultural contours and their significance are discussed in the larger context of a western political cultural and stem from a series of in-depth qualitative interviews. It is only after the full range of cultural issues is considered that conflict can be minimized and the true meaning of the West better understood.

Keywords: policy, Grand Staircase-Escalante National Monument, economics 


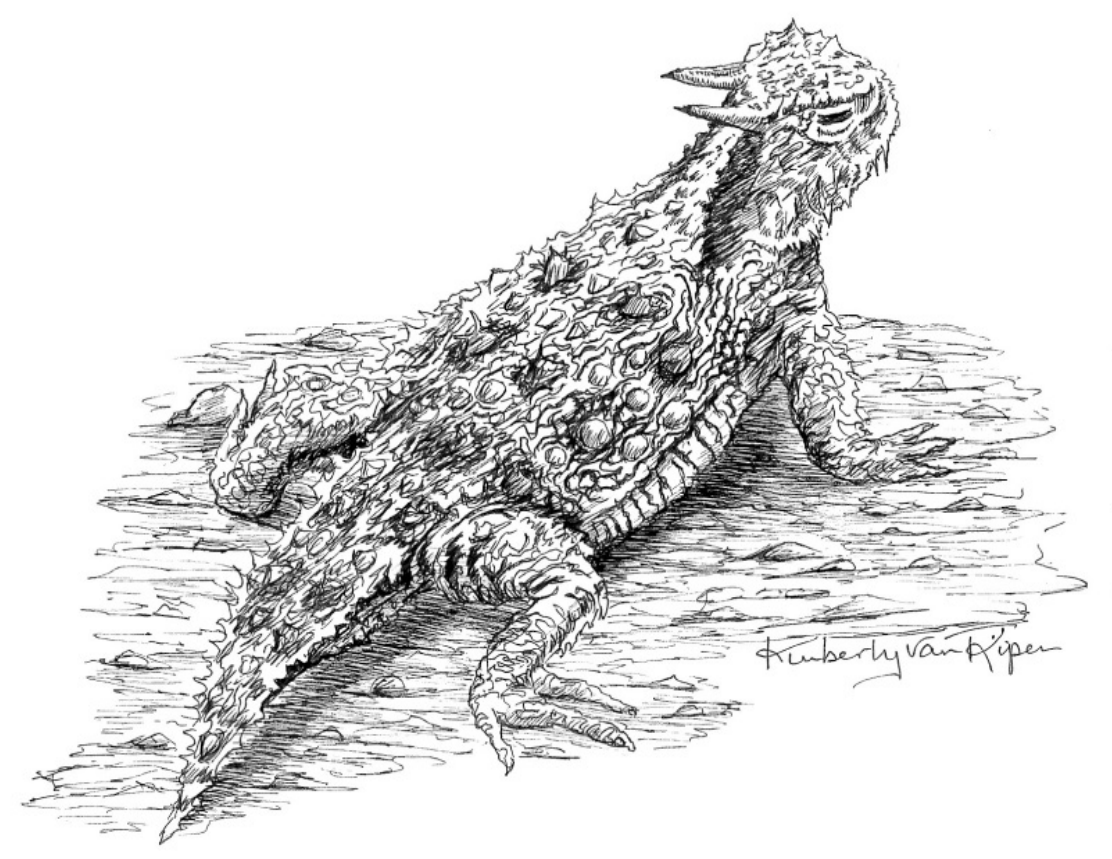

Drawing of desert horned lizard, Phrynosoma platyrhinos (copyright and courtesy of Kimberly Ann van Riper). 


\title{
Proceedings of the Fifth Biennial Conference of Research on the Colorado Plateau
}

\author{
Edited by Charles van Riper III, Kathryn A. Thomas, and Maureen A. Stuart
}

The 13 chapters in this book were selected from 105 research papers presented at the Fifth Biennial Conference of Research on the Colorado Plateau. Held 15-18 October 1999 in Flagstaff, Arizona, the conference was hosted by USGS Forest and Rangeland Ecosystem Science Center Colorado Plateau Field Station (CPFS) and Northern Arizona University. The meeting theme centered on research, inventory, and monitoring of lands over the Colorado Plateau, with a focus on the newly created Cooperative Ecosystem Studies Unit (CESU) at Northern Arizona University.

This is the fifth volume in a planned series of Colorado Plateau Proceedings, highlighting research and resource management efforts related to physical, cultural and biological resources within the biogeographic province of the Colorado Plateau. Many of the protocols and management techniques presently being utilized in land management units over the Colorado Plateau are a result of collaborative work among the USGS Colorado Plateau Field Station staff, university and agency scientists, with land managers. The scientific work published in this Proceedings Series contributes significantly to those collaborative efforts. It has been clearly demonstrated that, because of similarities across the Colorado Plateau, techniques that work in one management unit are applicable to many other areas throughout the ecoregion, and to other locations in the country that have similar habitat and climatological conditions.

The 13 contributed papers each constitutes a chapter, with the book being divided into three subsections: I. Cultural Resources; II. Biological Resources; and, III. Physical Resources. Each paper selected for publication in this Biennial Conference Proceedings represents original research, not published in another location, and that has been peer reviewed by scientists from that research discipline.

\section{Cultural Resources}

This book opens with a chapter by Loeser et al. focusing on a cultural/social controversy that presently has center-stage on the Colorado Plateau-public lands grazing management. In the past, research information that has provided a foundation for determining levels of public lands grazing has been based on biomass and species composition of aboveground plant assemblages. Loeser et al. argue that measurements at multiple trophic levels offer additional information and provide a tractable approach for investigating grazing impacts on underlying ecosystem processes. They feel that the present grazing controversy should move beyond the simplistic approach of grazed versus ungrazed comparisons, and address a wider range of potential grazing practices. One focus of this chapter is that, not only should plant biomass and species composition be considered, but we also need to examine below ground grazing impacts. Preliminary data from Loeser and his colleagues' ongoing study suggest that cryptogamic crusts and diatoms below the soil-surface are most greatly affected by intense grazing pressures. In conclusion they argue that we need to frame the grazing debate into an assessment of what are the best overall socio-economic returns, when balanced with environmentally sensitive practices for the Colorado Plateau.

The second chapter illustrates another cultural/social challenge on the Colorado Plateau, that being regulating use of remote locations to maintain/enhance the value of solitude. Roberts and 
Gimblett provide readers with a background on challenges facing regulation of rafting traffic on the Colorado River. This paper provides managers with a model that presents options for regulating riverrafting traffic along one of the premier white-water rivers in the world. The authors, after conducting interviews with guides who had undertaken Colorado River trips, add artificial-intelligence algorithms developed from the interview process. The resulting simulation engine uses elements of fuzzy logic in the model's decision structure. The fuzzy logic theory employed by the authors provides a robust and full range of decision-making tools that are suitable for capturing much of the nuances inherent in making complex decisions in a natural environment. Roberts and Gimblett then utilize actual river-trip data, and compare their model predictions to 15-day trips and to trips of longer duration. The focus of the authors' modeling effort is to provide for a balance between solitude required by visitors, with increased demands for a greater number of permits for Colorado River trips. They feel that this balance can be accomplished, while still minimizing impacts on natural resources along the river corridor.

\section{Biological Resources}

This section comprises the next 10 chapters of this book, first covering animals, then vegetation, and closing with two modeling chapters on wildlife/habitat associations. Chapter \#3 examines the influences of habitat types, water sources and movement barriers to pronghorn antelope in northern Arizona. Utilizing a Geographic Information System and data collected from 17 radio-collared animals captured within the environs of Wupatki National Monument in northern Arizona, the authors show that pronghorn antelope movements were most greatly affected by fencing along main thoroughfares, historical presence of animals, forage succulence and permanently available water sources. They conclude the chapter by encouraging management agencies to enhance communication and to consider managing pronghorn antelope across a broader landscape than just their individual land units.

In Chapter \#4 Brian Wakeling compares mule deer demographic responses to weather variables throughout Arizona. Utilizing data from Arizona Game and Fish Department winter mule deer surveys, monthly precipitation, and Palmer drought severity index values, the author examines weather relationships with fawn:doe and buck:doe ratios among game management units throughout the state. He demonstrates that statewide mule deer population estimates show only a modest relationship with weather patterns, but that it does explain $40 \cdot 50 \%$ of the variation. Habitats at climatic extremes (e.g., desert and montane) had a better fit in his model that did more moderate habitat types (e.g., grassland and piñon-juniper woodland habitats). Wakeling concludes by suggesting six other confounding variables that contribute to changes in deer numbers, but argues that climatic regimes still have the largest influence on overall mule deer abundance throughout Arizona.

The next chapter (\#5) moves from the large mammal arena to work on amphibians and reptiles. Drost et al. summarize their 1997-98 study that inventoried the herpetofauna of Petrified Forest National Park. Utilizing pitfall traps, visual encounters, artificial cover boards and night driving, the authors identified over 1.5 thousand individual reptiles and amphibians. Their data show that the herpetofauna at Petrified Forest NP is comprised of 16 reptile and seven amphibian species, of which one is a first record for northeastern Arizona and another a new record within the state of Arizona. This diverse assemblage of species is a result of individuals from three biogeographic regions (Southern desert/grassland, Great Plains, and Great Basin) that overlap at the park. The authors point out that Petrified Forest NP is one of the few large tracts of protected short-grass prairie on the southern Colorado Plateau, that still remains in semi-pristine condition, and as such supports regionally rare grassland herpetofauna species.

Chapter \#6 examines the potential influence of changing water temperature on native fish within the Colorado River corridor. Timothy Hoffnagle compares differences in temperature, turbidity, 
dissolved oxygen and $\mathrm{pH}$ of backwaters between fluctuating vs. short-term steady flows that result from discharges of Glen Canyon Dam. The author cautions managers that they should more closely examine the potential impacts of a steady flow regime on native fish, prior to implementation of this discharge regime. He raises this caution because of decreases in dissolved oxygen and increases in turbidity of backwaters that he found under steady flow regimes.

Chapter \#7 of the Biological Resources section provides a transition into terrestrial wildlife management, where Wakeling et al. examine the selection of roost trees by Merriam's turkeys in northcentral Arizona. The authors compare 13 known roosting trees with 13 paired random trees $>40 \mathrm{~cm}$ dbh. They found that turkeys selected significantly older and larger trees that had greater height to first limb in addition to greater surrounding basal area. From their data, Wakeling et al. develop a model that, utilized in conjunction with other existing models, should allow land managers to more accurately rank and prioritize potential Merriam's turkey roosting habitat.

Chapters \#8 and \#9 move into a closer examination of impacts resulting from ponderosa pine stand treatment, dealing with butterfly densities and forest health, respectively. In Chapter \#8 Griffis et al. document changes in adult butterfly populations among unmanaged, mechanically thinned, prescribed burned, and wildfire-affected stands of ponderosa pine near Flagstaff, Arizona. Although they did not detect a significant effect of stand treatment on butterfly densities, they suggest that important treatment effects may have been masked by several factors including butterfly movement among plots. In the next chapter (\#9) Bailey et al. examine landscape-level silviculture effects on ponderosa pine forests around Flagstaff, AZ. Testing among the four forest-treatment types outlined in the previous chapter, the authors found that unmanaged stands had a higher density of smaller diameter, suppressed ponderosa pine. Burned treatments had a significantly greater number of dead stems/ha, but seedling density did not differ among the four treatments. Bailey and his coworkers argue that the greater density of small diameter trees in unmanaged forest represent a condition that would enhance stand replacing wildfires, especially during drought years.

The final vegetation chapter by Floyd, Hanna and Salamacha deals with ecosystem response to fire at Mesa Verde National Park, focusing on post-fire invasion by 'noxious weeds.' Of the major habitat types in Mesa Verde they found that, following a fire, old-growth piñon-juniper woodlands were the most susceptible to noxious weed invasion. The authors then evaluated the effectiveness of mechanical removal, herbicide application and native grass seeding on inhibiting noxious weed expansion following two fire events (1989 and 1996). They conclude this chapter by suggesting that native perennial grass seeding within 3 years of a fire is the most effective way to reduce noxious weed proliferation.

The last two biological chapters deal with modeling studies of wildlife/habitat associations over portions of the Colorado Plateau. Chapter \#11 provides the reader with an introduction to the Southwest Regional Gap Analysis Program that is a second generation GAP analysis of the five states (Arizona, Colorado, Nevada, New Mexico and Utah) that comprise the Colorado Plateau. Jacobs et al. explain how, using a cooperative approach, their new program will develop new Geographic Information Systems (GIS) data themes for land cover, vertebrate species distributions, and land stewardship across five states. These GIS layers will be seamless across state boundaries and of finer ( 5 ha) resolution than previous GAP data. The authors plan to utilize these new data layers to better evaluate habitats of concern and conservation status of vegetation types and vertebrate species over the 5-state region. They believe that these new GIS products will allow land managers, policy makers, and planners to make better-informed land-use decisions over the Colorado Plateau.

Chapter \#12 by Hartley and Aplet presents a newly developed model that projects potential wildlife habitat corridors in the Greater Grand Staircase-Escalante ecosystem. Utilizing principles of 
island biogeography, the authors apply a model developed for grizzly bears in Montana to habitat surrounding Grand Staircase-Escalante in southern Utah. They point out that the model is based on four assumptions: 1) good corridors are primarily composed of good habitat; 2) humans pose problems for successful wildlife transit; 3) current human developments are permanent; and, 4) least-cost paths constitute the best routes of transit. The authors import Utah GAP GIS data into their model and produce a cost surface grid for each species of concern. Areas that they identify as potential important corridors are the East Fork of the Virgin River and the Dixie National Forest northeast of Bryce Canyon National Park.

\section{Physical Resources}

The final chapter of the Fifth Biennial Conference Proceedings deals with recent trends of climate change over the Colorado Plateau. In this 13th chapter John Spence focuses on characterizing recent trends in climate changes within the central Colorado Plateau. Utilizing long-term weather station data from southern Utah and northern Arizona, he demonstrates that climate patterns over the past halfcentury have changed in this region. Annual minimum temperatures have increased significantly in most areas. Maximum temperatures have declined some at higher elevation climate stations. Spence also points out that precipitation has changed little except for a slight increase during the winter. He also found no evidence for a strengthening of the summer monsoon, a prediction of some global warming models. The chapter concludes with a discussion of how these changing weather patterns might potentially impact vegetation and rare plant species on the Colorado Plateau.

\section{Abstracts}

\section{REFRAMING THE GRAZING DEBATE: EVALUATING ECOLOGICAL SUSTAINABILITY AND BIOREGIONAL FOOD PRODUCTION \\ Matthew R Loeser, Thomas D. Sisk, Timothy E. Crews, Kurt Olsen, Craig Moran and Christina Hudenko}

The semi-arid grasslands of the Colorado Plateau are productive, diverse, and extensive ecosystems. The majority of these ecosystems have been altered by human land use, primarily through the grazing of domestic livestock, yielding a plethora of environmental and social consequences that are tightly interconnected. From an agroecological perspective, untangling these issues requires both an understanding of the role of livestock grazing in bioregional food production and the effect of that grazing on ecological sustainability. To address the former, we discuss the importance of cattle ranching as a bioregional food source, including estimates of meat production and water use in Arizona. To address the latter, we present data from a long-term project addressing changes in native plant community composition, under a range of alternative livestock management strategies. Our study site near Flagstaff, AZ includes four different management treatments: (1) conventional low-intensity, longduration grazing rotations; (2) high-intensity, short-duration rotations; (3) very high-impact, very shortduration grazing (to simulate herd impact); and, (4) livestock exclosure. Preliminary results suggest belowground properties are responding more quickly to grazing treatments than aboveground properties. Particular response variables, such as cyanobacteria and diatoms, show a marked short-term response to very high-impact, short-duration grazing, but long-term implications are as yet unknown.

Keywords: ecological sustainability, bioregional food production, livestock grazing, biological diversity, participatory research.

COMPUTER SIMULATION FOR RAFTING TRAFFIC ON THE COLORADO RIVER Catherine A. Roberts and Randy Gimblett 
A computer program called the Grand Canyon River Trip Simulator (GCRTSim) has been developed for use by managers at the Grand Canyon National Park. GCRTSim consists of a database, simulator, and extensive analysis tools. The database will eventually contain approximately 500 trip diaries, collected in 1998 and 1999, that report stops for activities and camping along 226 miles of the Colorado River corridor within the park. The simulator provides park managers with the opportunity to set prospective launch schedules for rafting trips and simulate rafting seasons using these launch calendars. Both the trip diary database and the results of the simulations can be analyzed using graphing tools. The analysis can provide insight into use levels that could impact both the recreational experiences and resources along the Colorado River corridor.

Keywords: Colorado River, Grand Canyon National Park, rafting, simulation, management, launch schedule, model.

\section{THE INFLUENCE OF HABITAT TYPES, WATER SOURCES, AND MOVEMENT BARRIERS ON} PRONGHORN ANTELOPE HOME RANGES IN NORTHERN ARIZONA

\section{Jill L. Bright and Charles van Riper III}

We studied distribution and movement patterns of 17 radio-collared pronghorn antelope (Antilocapra americana) within the environs of Wupatki National Monument in northern Arizona. Aside from pronghorn gender differences, individual animal and herd movements were specifically influenced by fencing along main thoroughfares, historical presence of animals, forage succulence and permanently available water sources. From data analyzed and modeled with an Arc Info Geographic Information System, the extreme fragmentation that we observed in our study animals in northern Arizona leads us to believe that rights-of-way fences are a major factor affecting pronghorn movements. To facilitate movement and interchange among herds, it is imperative to reduce the effect of fenced rights-of-way so that pronghorn can freely move as perturbations occur (e.g., winter storms, droughts, fire). Another factor affecting localized movement and influencing home range is permanently available water, particularly within Wupatki N.M. Draw down of the water table by wells, along with anthropogenic manipulation of former natural watering sites, have negatively influenced locations where animals historically watered. This has resulted in no permanent water sources remaining within Wupatki N.M. In fact, we found greatest movement out of the park to secure water during September, that time of year when pronghorn are most heavily harvested in northern Arizona. If wildlife managers desire to better manage and coordinate pronghorn populations over a large fragmented landscape in northern Arizona, they will have to pay closer attention to fenced transportation corridors and to the distribution of water sources.

Keywords: pronghorn antelope, Antilocapra americana, movements, home ranges, fences, livestock grazing, GIS, highways, Wupatki National Monument

\section{MULE DEER DEMOGRAPHIC RESPONSES TO SELECT CLIMATIC VARIABLES IN ARIZONA Brian F. Wakeling}

To determine what effect climate has potentially had on recent demographic shifts and population declines of mule deer in Arizona, I studied the relationship of monthly precipitation and Palmer Drought Severity Index (PDSI) values with Arizona Game and Fish Department winter mule deer (Odocoileus hemionus) survey fawn:doe (FDR) and buck:doe (BDR) ratio data. Seven of 37 Game Management Units (GMUs) had no relationship between measured climatic variables and FDR, while 22 other GMUs had relationships with adjusted R2 of $<0.350$. Thirteen of 37 GMUs had no relationship between measured climatic variables and BDR, while 19 GMUs had relationships with adjusted R2 of $<$ 0.350. Pooling GMUs into similar habitats did not improve the modeled fit of relationships between 
demographic parameters and climatic variables. Habitats at climatic extremes (i.e., desertscrub and montane conifer habitats) demonstrated a predictable and superior model fit with FDR, more so than other habitats (i.e., Mohave desertscrub, chaparral and desert scrub, and grassland and woodland habitats), suggesting climate has a greater influence on recruitment in less moderate climates.

Statewide mule deer population estimates showed a relationship with PDSI data with an adjusted R2 of 0.446 . This apparent weak explanatory ability is probably the result of some combination of: (1) mule deer demographics responding to other confounding factors such as predation, habitat alterations or succession, or sport harvest, (2) climatic variation not driving population declines across Arizona, (3) other climatic variables, such as temperature, having a greater influence than precipitation on PDSI, (4) demographic parameters responding to a combination of climatic factors in addition to those I evaluated either directly or through vegetative influences (nutrition or cover), or (5) survey data is not accurately representative of the population. However, the explanation of $40-50 \%$ of the variation in statewide mule deer population numbers does suggest that climatic variables do have a strong influence in determining deer numbers throughout the state.

Keywords: Arizona, climate, mule deer, Odocoileus hemionus, Palmer Drought Severity Index, precipitation.

\section{HERPETOFAUNA SURVEY OF PETRIFIED FOREST NATIONAL PARK, ARIZONA Charles A. Drost, Trevor B. Persons, and Erika M. Nowak}

We present the results of an amphibian and reptile inventory conducted in 1997-1998 at Petrified Forest National Park. Using visual encounter surveys, pitfall trapping, artificial cover boards, and night driving techniques, we recorded 1,628 individual amphibians and reptiles (exclusive of larval amphibians) of 23 species. The species total includes seven amphibians, nine lizards, and seven snakes. Two of the lizard species (both of them whiptail lizards, genus Cnemidophorus) are new to the park. Small populations of the little striped whiptail are the first records for Petrified Forest, and also the first reported occurrences in Navajo and Apache counties. The New Mexico whiptail (probably introduced) is the first report for the state of Arizona. Petrified Forest National Park has a diverse herpetofauna, with species from varied biogeographic regions (Great Plains, Great Basin, and southern deserts and grasslands) occurring together in the park. The park is one of the few remaining large protected areas of grassland habitat on the southern Colorado Plateau, and supports regionally rare grassland amphibians and reptiles.

Keywords: amphibians, reptiles, Petrified Forest National Park, Arizona, Little Colorado River basin, grasslands, inventory, habitat associations, biogeography.

\section{CHANGES IN WATER TEMPERATURE OF BACKWATERS DURING FLUCTUATING VS. SHORT-TERM STEADY FLOWS IN THE COLORADO RIVER, GRAND CANYON Timothy L. Hoffnagle}

Discharge from Glen Canyon Dam, Arizona, fluctuates in a diel pattern which may affect native fishes and their habitats in the Colorado River, Grand Canyon. Differences in water temperature, turbidity, dissolved oxygen (DO) and $\mathrm{pH}$ in main channel and backwater habitats were compared between fluctuating and short-term (3-day) steady discharge regimes. Mean temperature in the main channel and backwaters displayed regular diel fluctuations, but mean temperatures were warmer under steady flows in both habitats $(\mathrm{P}<0.0)$. Mean main channel temperature was $8.36^{\circ} \mathrm{C}$ under fluctuating flows and increased to $8.92^{\circ} \mathrm{C}$ under steady flows. In backwaters, mean temperature increased from $11.91^{\circ} \mathrm{C}$ to $14.18^{\circ} \mathrm{C}$, and minimum, maximum and diel temperature range were higher under steady flows $(\mathrm{P}<0.01)$. Mean and minimum DO decreased and range of DO increased $(\mathrm{P} \leq 0.03)$, while mean, 
maximum and range of $\mathrm{pH}(\mathrm{P} \leq 0.03)$ increased in backwaters under steady flows. Mean turbidity did not significantly change $(\mathrm{P} \geq 0.35)$. These water quality changes may affect native fish populations through their influence on primary and secondary production and the potential for a change in non-native fish community. These factors should be more closely examined before implementation of a steady flow regime, construction of a temperature control structure or other changes that might increase water temperature in the Colorado River in Grand Canyon.

Keywords: temperature, dam discharge, fluctuating flow, steady flow, Colorado River, Glen Canyon Dam.

\section{PONDEROSA PINE TREE SELECTION BY ROOSTING MERRIAM'S TURKEYS IN NORTH-} CENTRAL ARIZONA

Brian F. Wakeling, Sally Weimann, Tim Jackson, Ben Dowler, Mechelle Eacret and Jennifer Gillis We compared ponderosa pine (Pinus ponderosa) trees used for roosting by Merriam's turkeys (Meleagris gallopavo merriami) in north-central Arizona with randomly selected ponderosa pine trees $\geq 40 \mathrm{~cm}$ diameter breast height ( $\mathrm{dbh}$ ) to determine which factors best identified trees that Merriam's turkey select for roosting. Roost trees were older $(\mathrm{P}=0.007)$, greater in diameter $(\mathrm{P}<0.001)$, taller $(\mathrm{P}$ $<0.001)$, had greater surrounding basal area $(\mathrm{BA} ; \mathrm{P}=0.086)$, and had a greater height to first limb $(\mathrm{P}=$ $0.063)$ than did randomly-located, $\geq 40 \mathrm{~cm}$ diameter trees. A logistic regression model, developed using a forward-stepwise approach, correctly classified $92.3 \%$ of all trees. Our model can be used to identify potential turkey roost trees by using only tree $\mathrm{dbh}$ and immediately surrounding BA Used in conjunction with existing models, this model now allows managers to more accurately rank and prioritize potential roosting habitat for land management planning.

Keywords: Meleagris gallopavo merriami, Merriam's turkey, ponderosa pine, roost.

\section{THE SUITABILITY OF BUTTERFLIES AS INDICATORS OF ECOSYSTEM CONDITION: A COMPARISON OF BUTTERFLY DIVERSITY ACROSS STAND TREATMENTS IN NORTHERN ARIZONA}

Kerry L. Griffis, Sheri S. Mann and Michael R. Wagner

Past human activities have resulted in a broad spectrum of ponderosa pine (Pinus ponderosa) stand conditions on the Colorado Plateau. A team of researchers at Northern Arizona University's School of Forestry is using common experimental plots to evaluate how highly-variable forest conditions influence potential ecological indicator species and guilds. Butterflies are one of several insect guilds that we are evaluating. During 1997 and 1998, we monitored populations of adult butterflies within replicated unmanaged, thinned, thinned and prescribed-burned, and wildfire-affected ponderosa pine sites. We did not detect a significant effect of stand treatment on butterfly abundance or similarity at the family level after two years, despite our large plot size (20-80 ha). Important treatment effects may be masked by butterfly movement between plots, heterogeneous forest stand structure, time since treatment, number of stands sampled, climate, and our sampling of adult butterflies. We suggest that sampling effort should be increased and data analyzed at the species level to quantify butterfly response to stand treatment

Keywords: Lepidoptera, Pinus ponderosa, indicator species, forest treatments, thinning, prescribed fire, wildfire.

STAND TREATMENT IMPACTS ON FOREST HEALTH (STIFH): STRUCTURAL RESPONSES ASSOCIATED WITH SILVICULTURAL TREATMENTS John Duff Bailey, Michael R. Wagner, and Jonathan J. Smith 
A major gap currently exists in our understanding of how landscape-level operational silviculture affects ponderosa pine (Pinus ponderosa) forest ecosystem health in northern Arizona. More than $70 \%$ of our forested landscape is in relatively young, even-aged stands resulting from a history of grazing, fire exclusion, atypical climatic events, and large ('yellow') pine removal. This multi-year, multiple-investigator project specifically examined stands that have been thinned to improve forest ecosystem health, or similarly thinned and then treated with prescribed underburning. These two treatments were not different from one another with respect to any aboveground structural characteristic. However, every measure of living overstory density (trees and saplings) was lower in thinned treatments than in untreated stands, and mean tree size (stem and crown) was consistently greater in thinned treatments. Areas burned by stand-replacing wildfire in 1996, now without an overstory, had zero seedlings and saplings as well as greater densities of standing dead trees than treated and untreated stands. The STIFH project as a whole is examining a range of species-specific and ecosystem responses to this spectrum of stand conditions, including fungi, insect, and understory plant composition. Keywords: ponderosa pine, forest ecosystem health, silviculture, thinning, prescribed fire.

\section{POST-FIRE TREATMENT OF NOXIOUS WEEDS IN MESA VERDE NATIONAL PARK, COLORADO}

\section{Lisa Floyd, David D. Hanna and Gary Salamacha}

Re-introduction of fire as a management strategy can be detrimental to conservation of native ecosystems by promoting "noxious weeds" within invasion-susceptible plant communities. This idea was central to treatments following fire in the piñon-juniper (Pinus edulis, Juniperus osteosperma) woodlands and mountain shrublands (Amelanchier utahensis, Quercus gambelii, Fendlera rupicola) of Mesa Verde National Park, southwestern Colorado.

Fire is an integral ecological process in piñon-juniper woodlands and adjacent petran chaparral shrublands. However, wildfires in 1989 and 1996 created opportunities for the proliferation of noxious weeds, especially Carduus nutans, Cirsium arvense, and to a lesser extent, Bromus tectorum. Oldgrowth piñon-juniper woodlands were especially susceptible to non-native invasion and required aggressive management actions. In this study, we evaluated the effectiveness of three treatment strategies (mechanical, herbicide, and native grass seeding) in these high risk habitats. Introducing native perennial grasses, within three years of the fire, proved the most effective treatment in reducing non-native plant proliferation

Keywords: noxious weeds, aerial seeding, Mesa Verde, species of concern

\section{MAPPING LAND COVER AND ANIMAL SPECIES DISTRIBUTIONS FOR CONSERVATION PLANNING: AN OVERVIEW OF THE SOUTHWEST REGIONAL GAP ANALYSIS PROGRAM IN ARIZONA}

Sarah R. Jacobs, Kathryn A. Thomas, and Charles A. Drost

The Southwest Regional Gap Analysis Program will build upon previous gap analysis programs conducted in Arizona, Colorado, Nevada, New Mexico, and Utah to provide products that are consistent among areas of this large geographic region. The program will develop new land cover, vertebrate species distributions, and land stewardship data layers using a cooperative approach and similar methods across the five states. The three data layers will be seamless across the five state region, and detailed in resolution and content. The data layers will be used in a gap analysis to evaluate the conservation status of natural habitats and vertebrate species within and among all five states, and point out biotic elements needing further protection or management attention. The program will also provide 
region-wide digital map and database products that allow land managers, planners, scientists, and policy makers to make better informed land use decisions.

Keywords: gap analysis, biodiversity, Southwest, Arizona, remote sensing, vegetation, land cover, wildlife habitat relationship models, GIS.

\section{MODELING WILDLIFE HABITAT CORRIDORS IN THE GREATER GRAND STAIRCASE- ESCALANTE ECOSYSTEM \\ Dawn Hartley and Gregory H. Aplet}

The Grand Staircase-Escalante National Monument was established, in part, to protect landscape connectors, a resource about which very little is known. In this paper we present a methodology that may be applied to identify potential wildlife movement corridors, in the absence of direct, scientific observation, but where something is known about habitat quality. Our analysis of the Monument landscape suggests that there are a number of places that deserve further scrutiny as potential movement corridors, including the heart of the Kaiparowits Plateau, the East Fork of the Virgin River east of Zion National Park, and the Dixie National Forest northeast of Bryce Canyon National Park. While we do not imply that these are movement corridors, we believe that our analysis provides new insights into potential habitat connectivity.

Keywords: movement corridors, GIS modeling, least-cost path analysis, landscape ecology, roads, national monuments, Bureau of Land Management, Gap Analysis Program, Utah.

\section{CLIMATE OF THE CENTRAL COLORADO PLATEAU, UTAH AND ARIZONA: CHARACTERIZATION AND RECENT TRENDS}

\section{John R. Spence}

The climate of the central portion of the Colorado Plateau is characterized using data from 27 climate stations. Mean annual temperature ranges from $16.9^{\circ} \mathrm{C}$ at Lee's Ferry $(978 \mathrm{~m})$ to $4.4^{\circ} \mathrm{C}$ at Bryce Canyon National Park (2412 m). Precipitation varies from 138-405 millimeters, and is weakly bimodal, with a strong late summer-early fall peak and a weaker late winter-early spring peak. Annual Thornthwaite potential evapotranspiration rates vary from 993 to $474 \mathrm{~mm}$, and at all stations, rates exceed annual precipitation. Temperature, precipitation and evapotranspiration are all strongly controlled by elevation. Latitude and longitude have some additional effects on some variables. A strong southeast to northwest decline in temperature occurs across the study region. An analysis of trends among nine stations with good records reveals that annual minimum temperatures have increased significantly in most areas since the 1960's. Those stations that fail to show this trend do show significant increases in winter minimum temperatures. Maximum temperatures have not responded in the same manner, and some high elevation stations document declines in maximum temperatures. Longer-term records at Escalante and Lee's Ferry confirm the warming trend back to 1925 and 1944, respectively. Precipitation amounts have changed relatively little, although there is a weak trend towards increasing winter season precipitation. There is no evidence in the data for a strengthening of the summer monsoon, which is a prediction of some global warming models. Potential impacts of global warming scenarios and changes in extent and timing of precipitation on the vegetation and rare species of the Colorado Plateau are discussed.

Keywords: central Colorado Plateau, climate, global warming, potential evapotranspiration, temperature, precipitation. 


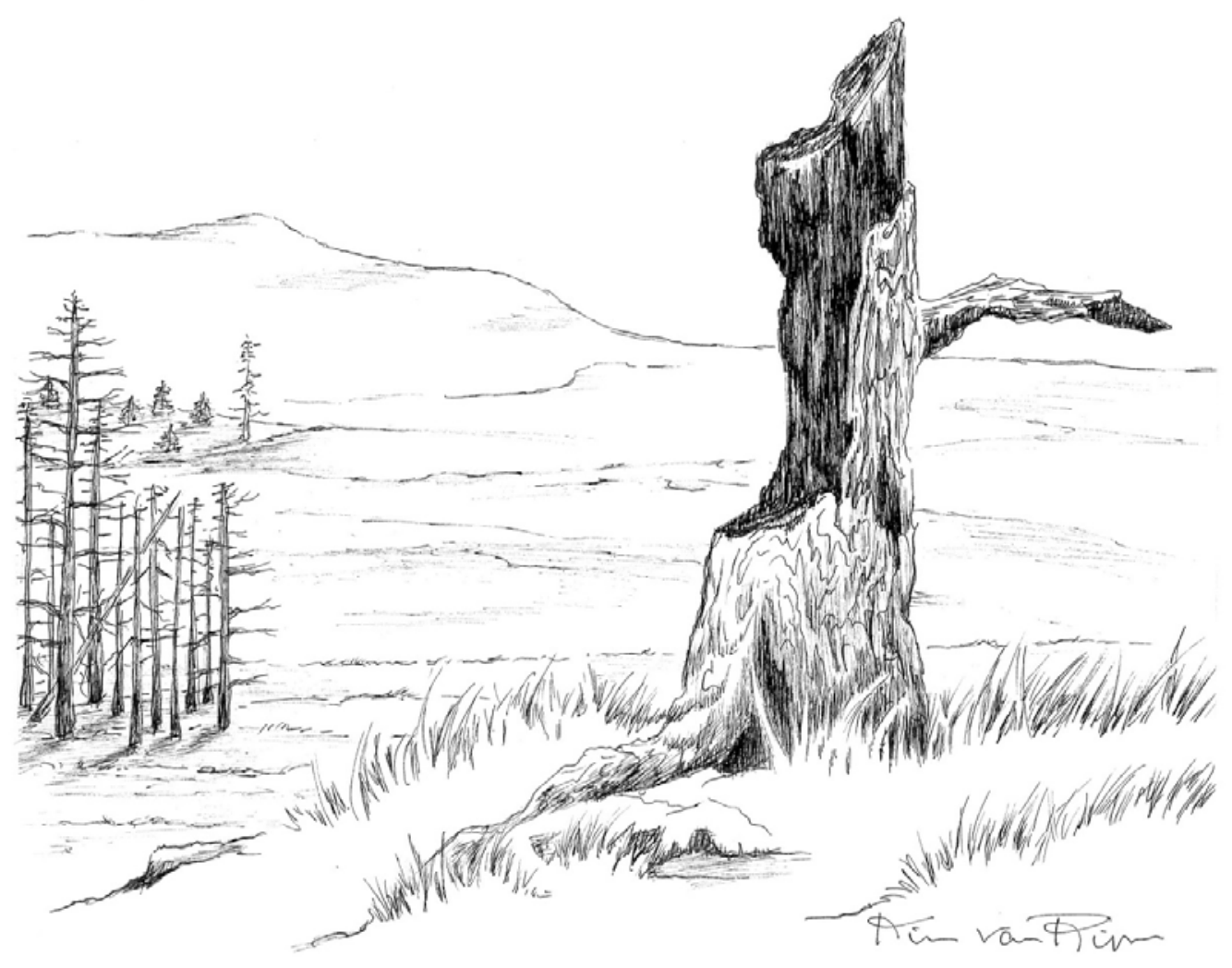

D Drawing of fire scene, ponderosa pine (Pinus ponderosa) forest (copyright and courtesy of Kimberly Ann van Riper). 


\title{
Proceedings of the Sixth Biennial Conference of Research on the Colorado Plateau: Cultural, Biological and Physical Research on the Colorado Plateau
}

\author{
Edited by Charles van Riper III and Kenneth L. Cole
}

This is the sixth volume in a planned series of books that focus on Research and Resource Management issues on the Colorado Plateau. These books highlight the integration of research into resource management efforts, as related to cultural, natural, and physical resources within the biogeographic province of the Colorado Plateau. Many of the protocols and management techniques presently being utilized in land management units over the Colorado Plateau are a result of collaborative work among the U.S. Geological Survey Southwest Biological Science Center staff, in combination with university and other partner agency scientists. The scientific works published in this series contribute significantly to presenting peer reviewed results of those collaborative efforts. It has been clearly demonstrated that, because of similarities across the Colorado Plateau, techniques that work in one management unit are applicable to many other areas. This is due primarily to the similarity of habitat and climatological conditions throughout the Colorado Plateau.

The 23 chapters in this book were selected from the 106 research papers presented at the Sixth Biennial Conference of Research on the Colorado Plateau. Held 5-8 November 2001 in Flagstaff, Arizona, the conference was hosted by the U.S. Geological Survey Southwest Biological Science Center's Colorado Plateau Field Station (CPFS), and Northern Arizona University. The meeting theme revolved around research, inventory, and monitoring of lands over the Colorado Plateau, with a focus on the newly created Center for Sustainable Environments (CSE) and the Colorado Plateau Cooperative Ecosystem Studies Unit (CESU) at Northern Arizona University.

The 23 contributed studies each constitute a separate chapter. Every paper that was selected for publication represents original research that has been peer reviewed by at least two scientists from that research discipline. Material presented in this book is information that has not been previously published in any other location. The book is divided into three subsections: Cultural Resources, Biological Resources, and Physical Resources.

Cultural Resources: The book opens with a chapter by David Wilcox, focusing on six benchmarks that he feels have created the intellectual and political datums from which the modern edifice of southwestern anthropological knowledge is based. Wilcox believes that the initial benchmark was created in the mid-19th century, by Albert Gallatin who demonstrated that the southwest could be incorporated intellectually into the American nation. A second benchmark was the 1906 Antiquities Act that limited collecting of cultural artifacts from federal lands, to public institutions. The publication in 1914 of a book by E. Huntington provides the third benchmark. Wilcox argues that this book, with appended tree ring data, establishes the dominant theory of causation for trajectories of human behavior on the Colorado Plateau, putting greatest stress on environmental variability. A fourth milestone was the Pecos Conference of 1927, from which resulted a powerful consensus about the basic sequence of cultural change on the southwest and the terminology needed to describe that change. The 1966 Historic Sites Preservation Act was the 5th and the Native American Graves Protection and Repatriation Act the 6th benchmarks. Both pieces of legislation have redefined the political balance of archeology on the Colorado Plateau, providing Native American tribes a significant voice in the formulation of their own histories and identities. Wilcox ties this chapter together with an elegant argument that oral traditions 
and histories will be a critical factor in the 'new' interpretation of anthropology on the Colorado Plateau.

The second chapter illustrates another cultural/social challenge on the Colorado Plateau, that being how to provide baseline cultural resource information to managers. Spurr, Geib and Collette present and discuss a model that they have developed of human use activity on the Kaiparowits Plateau, in the Grand Staircase-Escalante National Monument. Their survey-sampling scheme permitted them to make comparisons across topographic and vegetative divisions of the national monument. Their work included 16,289 acres (about 2\% of the monument), and provides detailed insights into settlement patterns and resource exploitation through time and among identifiable cultural groups on the Kaiparowits Plateau. The authors also detail 13 excavation sites that contribute to refinement of models concerning past human activity.

Chapter \#3 provides readers with an insight into the extent of visitor impacts of the newly created Grand Canyon-Parashant, Vermillion Cliffs and Grand Staircase-Escalante National Monuments. Foti and DeMillion point out that the continually increasing human recreational use of the southwest has led to increased natural and cultural site disturbances. If left unchecked, this may well threaten resource integrity and compromise efforts at sustainable recreation use of the monuments. The authors employ a rapid site inventory (RSI) method that quickly allows them to collect site attribute information. This technique also incorporates GPS location information and digital images of the area. Over 1500 RSIs were completed in their study areas, about one-third in the backcountry and the reminder along roadsides. Foti and DeMillion conclude by arguing that, as recreational impacts become an increasing factor in site disturbance, control sites will become increasingly important to managers so that they can better assess human limits within sustainable wild land recreation environments.

The fourth chapter of the cultural section documents the efforts and challenges of federal agencies to implement the 1964 Wilderness Act. This study focused on the 37-year history of competing 'wilderness' interests within the National Park Service. Ostergren discusses National Park Service practices that may present obstacles to future wilderness designation. He then identifies the politics that at first may appear intractable, but he feels may be less of an obstacle than most perceive. One major obstacle, especially for the National Park Service, seems to be that many politicians lump all federal lands under the same wilderness mandate. Thus the more secure national park lands are treated in the same arenas as U.S. Forest Service and Bureau of Land Management lands.

The final cultural chapter (\#5) by Jacobs et al. discusses the need and opportunities for increased federal research on Native American Lands. Although tribal lands make up significant portions of the Colorado Plateau (18\%) and of Arizona (25\%), these less developed lands have rarely been the focus of detailed study. Research can often be complicated by landscapes fragmented by ownership boundaries, and the differing management concerns of multiple groups. This chapter presents a framework for developing greater collaboration between federal scientists and Native Americans, focusing on perspectives of the Hopi tribe.

The Biological Resources section comprises the next 16 chapters of this book, first covering large and small mammals, followed by birds, then grazing issues, paleontological studies, and finally invertebrates (i.e., zebra mussels). The opening chapter provides a state-of-the-art summary of mammal biogeographical patterns on the Colorado Plateau. The next large mammal chapter highlights the continually increasing problems centering on the wildlife-urban interface. The following four chapters move to smaller mammals (i.e., rodents), followed by chapters on fire impacts, vegetation, birds, and then paleontological resources on the Colorado Plateau. The biological resources section closes with a chapter on invertebrates. 
Chapter \#6 launches the biological section with a treatise of mammalian biogeography over the Colorado Plateau. Carl Zimmerman and his students have worked on southwestern mammal fauna for over 25 years, and this chapter provides a summary of that extensive quarter-century of research. The authors examine the influences of habitat types, water sources and movement barriers to 126 mammal species on the Colorado Plateau. Utilizing a Geographic Information System (i.e., aerographic approach) and data collected from many years of fieldwork, Zimmerman and Carr demonstrate that mammal biogeography is most greatly influenced by 'zones of overlap' within the Colorado Plateau. They demonstrate that the patterns of mammal species richness is related to latitudinal and longitudinal gradients, with richness increasing from south to north over the Colorado Plateau. Variation in elevation was not a major contributing factor to species richness. They also demonstrate that the extensive prehistorical erosion of the Colorado River, forming the Grand Canyon, has posed a formable barrier to mammal dispersal. They conclude the chapter by pointing out that five mammalian species have historically been extirpated from the Colorado Plateau, and that the extensive economic opportunities that presently exist (e.g., exploitation of coal, gas and oil, along with logging, grazing, and tourism), need to be carefully considered in light of the fragility of many remaining mammalian species. This behooves management agencies to enhance communication with all land-owners and to consider mammal biogeographical distributional patterns in future management policies of their individual land units.

In Chapter \#7, Tucker et al. compare elk demographic responses in relation to residential development in the Hualapai Mountains in northwestern Arizona. Utilizing data from Arizona Game and Fish Department radio-collared elk $(n=7)$, the authors examine animal movement patterns over an annual cycle. Comparing climate and weather relationships, resource availability, and available vegetation types with elk movement patterns, they found elk inextricably tied to residential petran montane forest. The elk were being substantially influenced by residential development, and the authors argue that the animals were reliant on supplemental feed, mineral (i.e., salt), and water resources provided by people within the residential development. They conclude by pointing out that artificial congregations of elk may result in greater predator (i.e., mountain lion) numbers within residential areas, thus enhancing the potential for future human-wildlife conflicts.

The next chapter (\#8) moves from the large mammal arena, to work on smaller mammals. Tad Theimer summarizes his 1999-2000 study that inventoried nocturnal rodent abundance and richness in pinyon-juniper (Pinus edulis, Juniperus osteosperma)woodlands prior to and following a major masting event. Utilizing Sherman traps with 6 study area grids, Theimer compared small mammal communities on limestone and cinder substrates. The author found that cinder sites generally had greater rodent abundances than paired limestone locations, but that extreme variance occurred as related to total pinyon mast production. The presence of congeners also had a significant influence on rodent species numbers.

Chapter \#9 examines the effects of soil type on caching and pilfering of Pinyon pine seeds by mice (Peromyscus spp.). Pearson et al., working at the same locations of Theimer (see previous chapter), document that soils at the two locations differed in particle size, nutrients and moisture levels. They hypothesized that these differences would influence seed detectibility and energetic requirements of caching and pilfering pinyon seeds. Utilizing an enclosure experiment, the authors found that soil type did affect pilfering and caching behavior of mice, with $65 \%$ of cached seeds pilfered from cinder soils while $91 \%$ of the seeds cached in limestone soils were pilfered. They conclude by suggesting that dispersal of seeds by mice may potentially benefit pinyon pine as the seeds are moved to more favorable soil micro sites with higher moisture and nutrient levels. 
Chapter \#10 of the Biological Resources section provides a transition into terrestrial wildlife management, where Converse et al. report on 2 years of small mammal trapping in Ponderosa Pine forests. Six forest areas in Arizona and New Mexico were sampled prior to various management treatments of thinning and burning. This chapter reports on the pre-treatment small mammal populations and evaluates the effectiveness of their study design. The chapter concludes that increased trapping effort will be required in order to study most animals, except for the three most common species.

Vegetation studies are brought into the Biological section of the book beginning with Chapter \#11. In this chapter Evalengista et al. examine the effects of fire on cryptobiotic crusts at the Grand Staircase-Escalante National Monument in southern Utah. Their data compare crusts on areas burned three, 10, and 50 years ago with nearby unburned sites. A four year old burn site was also examined that had received a post-burn mechanical re-seeding treatment. Their results suggest that young crusts are initially reduced by fire, but rebound to their pre-burn extent within 10 years. Between 10 and 50 years, young crusts then exceed their pre-burn extent. Older and well-developed crusts are greatly reduced by fire and show little recovery even after 50 years. The mechanical re-seeding of a burn site had a far more detrimental effect on the soil crusts than did the fire. While the re-seeded burn site showed no recovery after four years, young crusts had fully recovered after only three years on an adjacent unseeded site.

The second vegetation chapter, by David Kriegshauser and Preston Somers, describes changes in riparian vegetation along the Dolores River, CO following the 1984 completion of McPhee Reservoir. Using sampling plots, transects, and aerial and oblique photography, this study documents changes in woody riparian species at one site along the river below the dam between 1983 and 2001. The sampling was conducted most intensively, with annual re-sampling, between 1993 and 2001. The authors' results demonstrate a $95 \%$ decrease in bare beach while shrubby vegetation cover (mostly willows) increased by $66.5 \%$. In that this project had a longer time span and more temporal detail than most studies of vegetation change, a more realistic and complete data set was collected on vegetation changes caused by the dam.

The next two biological chapters deal with studies that model grazing and habitat associations over portions of the Colorado Plateau. Chapter \#13 provides the reader with an identification system of ecological indicators of ecosystem health. Munoz et al., working over Diablo Trust lands on the southern Colorado Plateau, explain how by using a cooperative approach, land managers can develop new ways in which grazing can be implemented through large-scale rangeland practices. The authors' proposed approach first develops Geographic Information Systems (GIS) data themes for land cover, vertebrate species distributions, and land stewardship. These GIS layers are seamless across all land management boundaries. The authors then utilize these new data layers to better evaluate habitats of concern and provide conservation of vegetation/vertebrate species by utilizing varied grazing practices and regimes. They believe that these newly created GIS products will allow land managers, policy makers, and planners to make better-informed land-use decisions.

Chapter \#14 by Guenther et al. examines the effects of grazing at the Grand Staircase-Escalante National Monument in southern Utah. Vegetation plots taken on two adjacent mesas allow comparison of a site with long-term grazing with one that has not been grazed for at least 75 years. The Deer Spring Point area has been grazed continuously for well over 100 years, while the adjacent No Man's Mesa has no record of grazing other than use by some goats (and possibly sheep) in 1927 and 1928. This study is exceptional in that the two adjacent areas compared are nearly identical in geology, soils, slope, and elevation. There was no significant difference in species richness at a small scale ( $1 \mathrm{~m}^{2}$ quadrat) between the areas, but at the larger scale $\left(1000 \mathrm{~m}^{2}\right)$ No Man's Mesa had more plant species. Shrub cover was higher at Deer Springs Point, while No Man's Mesa had more highly developed cryptobiotic crusts. 
This chapter offers a detailed inventory and accurate quantification of the vegetation found on these two mesas.

The next three chapters cover management aspects of avian resources on the Colorado Plateau. Chapter \#15 deals with Bald Eagles along the Colorado River, focusing on Grand Canyon and Glen Canyon national parks. The authors provide a summary of their 1993-1995 Bald Eagle monitoring activities along the Colorado River. Focusing on the Nankoweap Creek area, van Riper and Sogge monitored stream conditions, spawning trout numbers, and human disturbance of Bald Eagles. They also conducted helicopter surveys along the Colorado River corridor from the Little Colorado River to Glen Canyon Dam. This study demonstrated that Bald Eagle concentrations were ephemeral, but when they did occur were closely tied to spawning rainbow trout numbers and fish availability in Nankoweap Creek, with the latter being influenced by the amount of stream bank undercutting from previous flood events. However, throughout the study they found that wintering Bald Eagle numbers were annually more consistent along the main Colorado River corridor. The authors conclude the chapter by providing management alternatives and pointing out that the entire Colorado River corridor is important to wintering Bald Eagles in Arizona.

Chapter \#16 examines the reliability of infrared (FLIR) surveys for wild turkeys within the ponderosa pine forests of northern Arizona. Wakeling et al., utilizing radio-collared groups of domestic and wild turkeys, tested the efficacy of FLIR surveys on wintering birds. They found that the new FLIR technology had limited success in detecting birds, particularly during nocturnal hours when birds were sedentary. The only time that they had increased detectibility was in the early morning when birds were leaving their roosting areas. Canopy closure did not appear to substantially influence detectibility. Due to the high cost of aerial tracking time, coupled with consistent enumeration of birds, the authors do not recommend the use of this management tool on the Colorado Plateau.

In Chapter \#17 Dickson et al. examine parts of the national Fire and Fire Surrogates program (FFS) that is attempting to document changes in wildlife with changes in forest structure among unmanaged, mechanically thinned, prescribed burned, and wildfire affected stands of ponderosa pine (Pinus ponderosa) forest. The authors provide pre-treatment measurements of southwestern bird communities within ponderosa pine, in proposed treatment blocks, measuring: 1) avian community structure, 2) bird species abundance, and 3) avian foraging patterns. In addition to documenting a baseline of information from which to make future comparisons, they observed an overall preference by foraging birds for ponderosa pine in the larger diameter classes, a resource use pattern in conflict with the FFS management target. Their preliminary analyses of avian community diversity and structure highlight the utility of acquiring robust pre-treatment data for the purpose of assessment of the responses of bird communities to proposed forest thinning manipulations. The authors felt that the integration of avian response variables, in a common spatial data format, will establish a powerful capability for addressing mechanistic drivers of wildlife responses to forest thinning and prescribed fire treatments.

The next three chapters focus on paleontological resources and their management on the Colorado Plateau. Chapter \#18 provides results of the first years of an inventory of paleontological resources at Petrified Forest National Park. Although the park was created primarily to protect its remarkable deposits of petrified wood, it also contains diverse vertebrate and invertebrate fossils. Faunal fossil remains were documented by Parker and Clements from 115 sites. Unlike petrified wood, which is very resistant to the elements, vertebrate fossils only persist temporarily once they have been exposed on the surface. The authors recommend that professional NPS staff conduct a periodic monitoring program to allow collection and curation of these fragile and temporary paleontological resources 
Chapter \#19 is an inventory of research done on paleontological resources from the caves of Grand Canyon National Park. Although only a tiny fraction of the park's many caves have been studied, there is an impressive amount of scientific literature that has been generated. Resources located in these caves have contributed to landmark studies in paleontology, paleoecology, archaeology, and geomorphology. These caves, spread throughout the length and range of habitats of the Grand Canyon, are known for their capability for preservation of bones and even ancient dung of extinct species. Remains of extinct species of mountain goat, ground sloth, camel, and horse have been found. Midden deposits left in the caves by packrats and ringtail cats also contain abundant fossil plant and animal fragments. The authors point out that the caves have also preserved fossil pollen and archeological materials such as split-twig figurines.

Chapter \#20 is a unique application of urinalysis to fossil urine. Using packrat middens from North America, and a few hyrax middens from Yemen, fossil crystallized urine deposits were rehydrated and then put through standard urinalysis tests. This is the first study of its kind, and it demonstrates great potential for future detailed analyses. The fossil urine samples were found to still contain preserved metabolic byproducts such as glucose, hemoglobin, nitrites, and proteins. These results suggest a new window into the physiology of animals that have been dead for over 20,000 years.

The final biological chapter deals with zebra mussels at Glen Canyon National Recreation Area. In chapter 21, Parker and Ritenour report a management policy developed for preventing the infestation of the Colorado River System by the zebra mussel, a rapidly spreading exotic species. Zebra mussels are native to Eastern Europe but were first noticed in North America in 1988. In the span of a decade, they have spread through much of eastern North America, inflicting billions of dollars in damage to boats and underwater structures. Because they are spread through contamination of boats by the microscopic reproductive stages of the organism, Glen Canyon National Recreation Area has developed a policy of cleaning any boat that has been recently used near infected waters. Visitor compliance with the cleaning is encouraged through educational measures and boat disinfection at no cost to the visitor. This proactive policy serves as an example what should be expanded elsewhere to help curtail the spread of this introduced organism.

The final two chapters of the book cover aspects of Physical Resources on the Colorado Plateau. Chapter \#22 provides a multi-objective analysis of the proposed rerouting of the Rio de Flag River in Flagstaff, Arizona. Poff and Tecle examine 20 earlier studies that deal with potential flooding along the Rio de Flag, a stream that meanders through the city of Flagstaff. Results of these studies were utilized by the Army Corps of Engineers, who ultimately recommended a rerouting plan that called for open and closed channels, along with a larger detention pond. With over $75 \%$ of the flood plain presently zoned for commercial and residential use, there is concern regarding the impacts of a 100-year flood event. In an effort to enhance the reliability of the Rio de Flag rerouting decision-making process, the authors modeled and examine 15 separate rerouting alternatives. Their models were evaluated with respect to 33 criteria that addressed various environmental, cultural, historic, economic, technical and social issues that had been raised by the community of Flagstaff, Arizona. Within this multi-objective decisionmaking framework, the authors present a preferred Rio de Flag channel improvement that best meets all concerns of the community.

Chapter \#23 examines past climate of the Colorado Plateau using stream flow records from the last 100 years and tree-ring data from the last 600 to 1000 years. In this chapter, Hidalgo and Dracup focus on characterizing past climatic trends and cycles in the upper Colorado River Basin, and their relationship to the Pacific Decadal Oscillation (PDO) and El Niño-Southern Oscillation (ENSO). The authors present evidence that a climate regime shift occurred around 1946-47. From 1906 to 1946 the Colorado River discharge was more positively correlated with the PDO, while from 1947 to 1998 they 
were negatively correlated. A review of previous work using longer-term tree-ring data as a proxy for the PDO, precipitation, and stream flow suggests a $\sim 20$ year cyclicity in both PDO and Colorado river flow from A.D. 1600 to the last third of the 19th century. These are lower frequency changes then have dominated the 20th century.

Any scientific work is never a single effort, but a direct result of assistance by many individuals. This book is no exception. We would especially like to thank the following scientific peer reviewers: Craig Allen, Sam Arundel, Chuck Avery, Don Bertollette, Dean Blinn, Matt Brooks, Bruce Bury, Ken Cole, Tom Edwards, Peter Gogan, Tom de Gomez, Tim Graham, Linda Jalbert, Dave Mattson, Jim Mead, Karen Mock, Barbara Phillips, David Pyke, Peter Rowlands, Cecil Schwalbe, J. Michael Scott, Harley G. Shaw, Tom Sisk, James Sprinkle, Ed Starkey, Jan van Wagtendonk, Richard Walker and David Willey, all who unselfishly devoted their time and effort to improving each chapter that they reviewed.

Ruth Jacobs, Gary Larson, Edward Starkey, Michael Collopy, Anne Kinsinger, and Dennis B. Fenn all provided encouragement and/or financial assistance for this publication. Melissa Shultz and Louella Holter helped in many ways with editorial details. We would particularly like to thank Kimberly Ann van Riper who contributed the line drawings that are found throughout this book. The dedicated USGS Colorado Plateau Field Station staff (T. Arundel, C. Drost, J. Graham, J. Hart, S. Jacobs, M. Johnson, E. Nowak, E. Paxton, M. Sogge, R. Stevens, K. Thomas, M. Stuart, D. Cawley, M. Saul and M. Rasmussen) provided much needed assistance during the 6th Biennial conference. Finally, we express deep appreciation to our wives (Sandra Guest van Riper and Melinda Cole) and to our children for their support and understanding during the time that this book was in production.

This work, like other research compilations that are centered on a particular theme, should help to focus attention on research presently being conducted over lands of the Colorado Plateau. In particular, we hope that National Parks, U.S. Forest Service, Bureau of Reclamation, tribal lands and the many new BLM National Monuments will be able to utilize the ideas and concepts presented within each chapter, to launch efforts toward enhanced management and stewardship of their lands in the southwest. Finally, if the material in this volume, can act as a stimulus for future support of research and management of cultural, natural and physical resources over the Colorado Plateau, it will make the organizational and editorial work of the past two years a worthwhile and productive effort.

\section{LOOKING FOR MIDDLE GROUND: ARCHAEOLOGY ON THE COLORADO PLATEAU TODAY David R. Wilcox}

Born of conquest, the American Southwest, with its northern wonderland, the Colorado Plateau, has long been regarded as a laboratory for anthropological inquiry (Fowler 2000), a place where the evolution and diversity of its inhabitants and the archaeological record they created can be visited, probed, and reported for the benefit and enjoyment of all. Moral dilemmas arise when power is exercised in relation to the pursuit of such knowledge, or when trust is betrayed, circumstances that are often unavoidable. Anthropological knowledge can be a personal quest, but most often it is pursued in the context of institutional frameworks that enmesh individuals into complex webs of group relationships and political responsibilities that regulate value choices and even prescribe aesthetic priorities. History affords the scientist a way to understand this matrix, and a space in which to reflect on his own options for action and their possible outcomes. We learn from this historical inquiry that a career in science is part of what the philosopher Nicholas Rescher (1985) called the "strife of systems." Science is intimately connected on many levels to philosophical debates that have lasted centuries, or even millennia (Rescher 1985). Like it or not, we are all gladiators in this arena of life. To provide a quick sketch of the main structural parameters of southwestern archaeology, as it relates to the Colorado 
Plateau today, I examine a series of six benchmarks that created the intellectual and political datums from which the modern edifice of anthropological knowledge about the Southwest was erected.

\section{Abstracts}

PATTERNS OF HUMAN ACTIVITY IN “THE HEART OF THE DESERT WILD”: ARCHAEOLOGICAL SURVEY AND TESTING ON THE KAIPAROWITS PLATEAU, GRAND STAIRCASE-ESCALANTE NATIONAL MONUMENT

Kimberly Spurr, Phil R. Geib, and Jim H. Collette

This paper summarizes an archaeological survey and testing project conducted by the Navajo Nation Archaeology Department (NNAD) in the Grand Staircase-Escalante National Monument, the country that Greer Chesher (2000) called the "Heart of the Desert Wild." A full report on this project is available elsewhere (Geib et al. 2001a), and only a summary of the important findings is presented here. The survey was conducted in two phases: the first during the summer of 1998 and the second in the summer of 2000. A limited test excavation program occurred during the spring of 2000, just prior to the second phase of survey. The impetus for the project was compliance with Section 110 (a)(1) of the National Historic Preservation Act (P.L. 89-665; 80 Stat. 915; 16 U.S.C. 470, as amended), which directs federal agencies to "undertake a program to identify historic properties under its jurisdiction or control." The project's primary goal was to provide Bureau of Land Management (BLM) managers with an objective basis for characterizing and estimating the density, distribution, and diversity of cultural resources on the Kaiparowits Plateau. A secondary goal was to examine patterns in the distribution of cultural remains that could reflect settlement and land-use strategies related to environmental zones or temporal periods. Both of these objectives had to be met by surveying approximately 2 percent of the entire 800,000 acre study area. A carefully constructed sampling regime developed for the survey allowed comparisons of site density across topographic and vegetative divisions of the plateau, offering insights into settlement patterns and resource exploitation through time and among identifiable cultural groups. The survey of 17,280 acres documented 710 archaeological sites and 816 isolated occurrences of artifacts that represent a wide range of activities over a period of at least 10,000 years. The baseline data generated by this survey will allow land managers to understand patterns of past human activity in the Monument as well as what natural or human-based threats must be considered in long-term planning to protect and preserve the remains of the past (Geib et al. 2001a). A tightly focused testing program at 13 sites investigated correlations between surface and subsurface manifestations of prehistoric features, and assessed the validity of criteria used during survey to assign date ranges to sites lacking diagnostic artifacts.

\section{HUMAN IMPACT INVENTORIES ON THE GRAND CANYON-PARASHANT, VERMILION CLIFFS, AND GRAND STAIRCASE-ESCALANTE NATIONAL MONUMENTS \\ Pamela E. Foti and Marcy A. DeMillion}

Recreational use of wildland areas in the Southwest has increased dramatically over the past three decades (Cordell 1999). This increased use of wildland resource areas has led to growing site disturbances from human impacts. Hammitt and Cole (1998) have noted that all wildland recreation activities disturb the natural environment, and the associated site impacts have the potential to affect soil, vegetation, wildlife habitat, and water. In addition, recreational impacts may affect paleontological, cultural, and historic resources.

Recreational impacts may seem insignificant in comparison to a catastrophic fire, a major insect infestation, or even site-specific mining or timbering disturbances. Continued human impacts that are ignored or go unchecked, however, offer the opportunity for significant alteration of the natural 
environment and provide a medium for the growth of an unsustainable recreation environment. The potential for site alteration from human recreational impacts and the anticipated increases in recreational use of wildlands (Cordell 1999) has left site managers increasingly concerned about their ability to protect the integrity of wildland resources.

This project was based on the planning and management framework of the Limits of Acceptable Change (LAC; Frissell and Stankey 1972). The amount and type of resource change due to human impacts to be tolerated on any site is a managerial decision; good managerial decisions lead to sustainable recreation environments. Effective managerial decisions require an informed framework of social and physical site data collection. In essence, the LAC process allows an agency resource manager to identify and control site limits within a framework of sustainability.

The LAC process consists of nine detailed steps of implementation, with four major components. The first component involves specification of acceptable and achievable resource and social conditions. In this step, managers are basically asking the question, what do you want on this wildland site? The second component of LAC is the analysis of the relationship between existing conditions and those judged acceptable. Baseline inventory data for wildland recreation sites are the most important elements in this step, with the managerial question, what do you currently have on the site? The next step is to identify managerial actions that might achieve the desired conditions - what action will you take to get to where you want to be on this wildland site? The final step is to monitor and evaluate the effectiveness of management on wildland recreation sites, and to ensure that managers know when resource change occurs on a site so that appropriate actions might be taken. The focus of this study was on the second component of LAC, gathering current baseline data on wildland recreation sites. These data can then be used in the management planning and implementation process to achieve desired site conditions.

\section{THE NATIONAL PARK SERVICE AND IMPLEMENTATION OF THE 1964 WILDERNESS ACT: THIRTY-SEVEN YEARS OF COMPETING INTERESTS ON THE COLORADO PLATEAU David Ostergren}

The 1964 Wilderness Act (P.L. 88-577) was monumental, as unique federal legislation designed primarily to protect areas for wilderness characteristics. Since then, designation of land into the National Wilderness Preservation System (NWPS) has been hotly debated within the U.S. Department of Agriculture Forest Service (USFS), as well as the three agencies within the U.S. Department of the Interior - the National Park Service (NPS), Bureau of Land Management (BLM), and Fish and Wildlife Service (FWS). Wilderness Areas are to retain their natural conditions where the forces of nature predominate and man is only a visitor (P.L. 88-577). Since passage of the Wilderness Act in 1964, Congress has designated Wilderness Areas amid controversy and debate, engaging and embroiling a wide range of actors and interest groups including pro-wilderness non-government organizations (NGOs), anti-wilderness NGOs, federal and state politicians, the White House, and the federal agencies themselves.

Of all federal wildlands that are not designated as wilderness, the territory within the NPS has some of the most restrictive guidelines and regulations for use. As a matter of policy the backcountry areas of many national parks are managed to protect their "wilderness character." Intuitively, if these areas were designated Wilderness by Congress they would require little or no change in management strategy. The central question of my presentation is why do these areas remain undesignated? This investigation sought to understand and document the obstacles to Wilderness designation on NPS lands and, in particular, on NPS lands on the Colorado Plateau. My first hypothesis was that I could identify key practices, or key political obstacles that, if overcome, would ameliorate further Wilderness 
designation on NPS land. There are NPS practices that are, strictly interpreted, incompatible with the Wilderness Act. Rather than being insurmountable obstacles in themselves, these practices are more likely to be caught up in political battles and used as levers to promote one ideology or another. My results indicate that in principle, everyone either supports more NPS Wilderness Areas, or at least doesn't object to further Wilderness designation on NPS lands. Unfortunately, nearly everyone also offered a caveat: these caveats provide the core findings of this article. My findings also indicate that interest groups make assumptions about "the other interest groups" that are not entirely true. My findings are not exhaustive. I am convinced that my results are not exhaustive because my second hypothesis that the Colorado Plateau offered a regionally unique set of political circumstances is false. Each Park Service unit has a unique set of circumstances both similar and dissimilar to those in other parts of the country. However, my examples and evidence reveal several trends that may be applied across the NPS, and suggest clear lines for further investigation to remove common misconceptions or indicate strategies for Wilderness designation.

\section{USGS AND HOPI TRIBE PERSPECTIVES ON RESEARCH COLLABORATIONS}

Sarah R. J. Falzarano, Arnold Taylor, Sr., and Kathryn Thomas

Traditionally, research studies have focused on the land administered by the funding agency (U.S. Army 1995), despite the fact that species and ecological processes cross land ownership boundaries. Studies are showing that ecological processes affect and are affected by neighboring landscapes, regardless of the land administrator. And, depending on the scale of the phenomenon being studied, the neighboring unit could be as close as a meter or as far away as hundreds of kilometers.

Research studies have recently been designed to include entire ecosystems rather than being constrained by administrative boundaries (Scott et al. 1993). Adjacent landowners appreciate that landuse decisions by neighbors can influence their land. In addition, the federal government is being asked to extrapolate research to all lands, not just federally owned properties.

The Gap Analysis Program, conducted by the USGS, maps the biota of a region, usually on a state by state basis. Biodiversity is estimated through the creation of maps of land cover (vegetation) and potential habitat for all terrestrial vertebrates in the region. The Southwest Regional Gap Analysis Project (Jacobs et al. 2001) is a multistate project that creates these maps for Arizona, Colorado, New Mexico, Nevada, and Utah; the maps will be continuous and seamless for the region. The project is inclusive of ecosystems within these five states. Within this multistate region, administrative boundaries are not considered to be ecological boundaries.

This paper is a result of the Biological Resources Discipline of the USGS approaching the Hopi Tribe to collaborate on the Southwest Regional Gap Analysis Project in Arizona. It outlines the need for research on tribal lands, gives the USGS and Hopi Tribe perspectives on research collaborations, and provides suggestions for successful interactions. The paper is specific to the Biological Resources Discipline of the USGS and the Hopi Tribe, but the information is applicable to other research teams desiring to work with various Native American tribes.

\section{MAMMALIAN BIOGEOGRAPHY OF THE COLORADO PLATEAU}

\section{Earl G. Zimmerman and Carla B. Carr}

The Colorado Plateau is a diverse region spanning some 375,000 sq $\mathrm{km}$ of the interior western United States. Studies of the mammalian fauna of the region are available; however, the most extensive are state surveys limited by political boundaries. These include surveys of mammalian distributions of Utah (Durrant 1952; Armstrong 1977), Colorado (Armstrong 1972; Fitzgerald et al. 1994), Arizona (Hoffmeister 1986), and New Mexico (Findley et al. 1975). Biogeography represents a component of 
each of these surveys, and one can extrapolate some of their discussions about statewide distributions to the Colorado Plateau; however, there is no published account of the mammalian fauna of the plateau as a biogeographic region that crosses state boundaries. Furthermore, biogeography has become a major component of the broader field of landscape ecology (Foreman and Godron 1986), and as such the field seeks not just to describe distributions but to present the interrelation of distributions to landscape patterns and processes. These patterns result from not only extant environments, but also those of the past that have influenced the current distributions of plants and animals.

The landscape diversity of the Colorado Plateau supports an extensive biodiversity, as well as the opportunity for increased impact by humans. The region has a long history of human impact, including that of Paleoindian cultures dating back 12-10 ka to the late Archaic occupation of the land by indigenous people. Europeans first visited the area in the late 1700s, but the most rapid invasion occurred after the 1840s (Jackson 1994). Despite this change in demographics, today nearly 27 percent of the Colorado Plateau is tribal land populated by Native Americans. As major sources for human development, the landscape diversity of the Colorado Plateau has offered economic opportunities in the exploitation of its resources for agriculture, mining, logging, military-related industries, and more recently tourism. The diversity, and therefore the aesthetic value, of the landscape is unequaled in North America, and more recently the Colorado Plateau has become a major region for recreation. Thus, assessing the mammalian faunal diversity and its biogeographic affinities is timely in light of the expanding human influence on the region.

\section{ELK HABITAT USE IN RELATION TO RESIDENTIAL DEVELOPMENT IN THE HUALAPAI MOUNTAINS, ARIZONA}

\section{Darren G. Tucker, Eric S. Gardner, and Brian F. Wakeling}

Elk (Cervus elaphus) are a species of special interest in Arizona, partially due to their population growth and expansion into previously unused habitats during the last 2 decades. Population growth and range expansion has resulted in conflicts with other land management practices in many areas. The elk population in the Hualapai Mountains has remained relatively stable during this time period and land use conflicts have not been prominent, although residential landowners in this desert mountain island habitat expressed favorable interest in the continued presence of elk (DGT, personal communications with residential landowners). Elk tend to be adaptable to a wide range of conditions (Geist 1982), but the vegetation associations and residential proximity within the Hualapai Mountains differ from other Arizona habitats. We investigated this population of elk to better understand habitat use in relation to residential development within this unique, discrete population.

In February of 1927, 25 Rocky Mountain elk were brought to Arizona by the Mohave Game Protective Association (a group of organized sportsmen) with the cooperation of the Arizona Game Department. The elk arrived in Kingman, Arizona on February 11, 1927. On February 14, horsemen herded the elk from Kingman to the Hualapai Mountains. Twenty elk survived to establish the population of elk in the Hualapai Mountains (Gooch, unpublished manuscript).

Although other studies have examined seasonal habitat use and migration patterns in large areas of contiguous elk habitat in Arizona (e.g., Brown 1990, 1994), none have focused on an area with residential developments within a limited area of suitable habitat, such as the Hualapai Mountains. This isolated population offers a unique opportunity to study habitat use in a residential interface with natural vegetation associations. Our objective was to examine seasonal habitat use of vegetation associations in relation to residential development. 
NOCTURNAL RODENT ABUNDANCE AND RICHNESS IN PINYON-JUNIPER WOODLANDS ON CONTRASTING SOIL TYPES BEFORE AND AFTER A MASTING EVENT

\section{Tad C. Theimer}

Trees like oaks and pines, in which many members of the population synchronously produce seed crops at multiyear intervals, are often referred to as masting species and the seeds produced in these years as "mast." In many of these systems, the mast serves as an important food resource for a variety of animals and can lead to increased reproduction in years following a mast and reduced population sizes in years of mast failure (McShea 2000). For example, rodent populations often increase in the year following a masting event, presumably because of the increased availability of food in the form of seeds (Gashwiler 1979; Ostfeld et al. 1996; Wolff 1996; McCracken et al. 1999; McShea 2000).

Comparative studies of pinyon pine communities growing on contrasting soil types in northern Arizona have shown striking differences in pinyon productivity that could have important implications for how rodent populations may respond to masting events. Soils derived from volcanic ash and cinders tend to be lower in water and nutrients compared to nearby soils derived from limestone, and pinyon pines on cinder soils grow significantly slower (Gehring and Whitham 1994). In addition, pinyon pines growing on cinder soils suffer high levels of attack by the cone and stem boring moth (Dioryctria albovitella), which results in significantly reduced cone production (Christensen et al. 1991; Christensen and Whitham 1993). Although the effects of soil type on seed nutritional content are unknown, trees on cinder soils produce more inviable seeds and seeds of smaller mass than trees on non-cinder soils (Gehring, personal communication). Given the striking differences in pinyon pine productivity across cinder and non-cinder soils, variation in mast production on differing soil types could lead to different population dynamics of rodents living in those areas. I investigated how the effects of soil type on tree productivity could potentially affect the nocturnal rodent community in a year of large pinyon cone production (a pre-mast year) and in a year of low cone production (a post-mast year). I tested two hypotheses. First, the lower productivity of cinder soils should result in overall lower abundances and lower species richness of nocturnal rodents in pre-mast years. Second, rodent populations on cinder soils should not respond to masting events as strongly as those on more productive limestone-derived soils due to the lower productivity of trees at cinder sites.

\section{EFFECTS OF SOIL TYPE ON CACHING AND PILFERING OF PINYON PINE SEEDS BY MICE Kristen M. Pearson, Kristin A. Covert, and Lee Ann Compton}

Seed caching rodents are well known for their influence on plant populations due to their role as seed predators and dispersal agents (Brown et al. 1979; Price and Jenkins 1986). Their predatory influence has been well documented in seed and seedling consumption studies (Heithaus 1981; Hulme 1994), and their seed dispersal role has been studied by following seed removal pathways, discovering cache sites (Giannoni et al. 2001; Li and Zhang 2001), and following the fate of the seeds (Vander Wall 1993, 1995a, 1998; Longland et al. 2001). Findings from these studies and others suggest that rodents may affect plant populations in many ways. The spatial distribution of seed shadows may be changed via seed caching, recovery, and pilfering patterns (Vander Wall 1990). Seed survival and germination may be influenced by breaking dormancy through handling methods (McAdoo et al. 1983) and by varying the depth of seed burial, thus affecting seed desiccation rates (Borchert et al. 1989) and detection by seed predators (Hulme 1994). Rodents may further influence germination and subsequent seedling survival by the microsites selected for seed deposition (Vander Wall 1997; Li and Zhang 2001).

Plants often require specific microsite characteristics for seed and seedling survival, depending on specific environmental conditions and the physiology of the plant (Harper 1977). Factors such as 
nurse plants, surface litter, substrate type, and particle size have been shown to have important influences on germination and survival due to their effects on sunlight exposure, soil temperature, moisture, and nutrients (Godinez-Alvarez and Valliente-Banuet 1998; Chambers 2000). Consequently, the micro-site in which rodents cache seeds may be very important to plant populations, influencing whether seeds germinate and seedlings live or die; however, very little is known about the factors that influence cache site selection.

\section{ESTIMATING SMALL MAMMAL ABUNDANCE ON FUELS TREATMENT UNITS IN SOUTHWESTERN PONDEROSA PINE FORESTS \\ Sarah J. Converse, Brett G. Dickson, Gary C. White, and William M. Block}

In many North American forests, post-European settlement fire suppression efforts have resulted in the excessive accumulation of forest fuels and changes to the historic fire regime, thereby increasing the risk of catastrophic wildfires (Cooper 1960; Dodge 1972; Covington and Moore 1994). To reduce this risk, it is necessary to develop treatments that will remove excess fuels while moving forests toward historical structural conditions and disturbance intervals, an approach currently being attempted in southwestern ponderosa pine (Pinus ponderosa) forests (see Covington et al. 1997; Fulé et al. 2001). Both prescribed fire and mechanical fuel treatments have been used for restoration. However, it is not known if fire surrogates such as mechanical fuel treatment are sufficient to achieve historical forest structure in the place of fire, or how these treatments will affect ecosystem function.

The national Fire and Fire Surrogate (FFS) Program is a cooperative effort among federal landmanagement agencies, universities, and private organizations to investigate the impact of fire and fire surrogate treatments on forest ecology and fire risk (Weatherspoon and McIver, unpublished report). The FFS approach applies a similar study design and sampling scheme on 13 study areas across the United States. The study areas consist of three replicate blocks (study sites) divided into four treatments (units): control, thin, burn, and a thin/burn combination. In accordance with the national protocol, treatment effects will be examined for several response variables in the general areas of vegetation, fuels and fire behavior, soils, entomology, pathology, and treatment costs and utilization economics. This paper focuses on a subset of the wildlife response variables outlined in the national protocol (Zack and Laundenslayer, unpublished report), namely small mammal abundance, and our subsequent modifications to this protocol. After the 2000 trapping season, we were concerned that the trap densities outlined by the national protocol were inadequate for robust estimation of small mammal population sizes. We therefore conducted an analysis of pre-treatment data, including an analysis of an increase in trap effort implemented on a limited number of treatment units in 2001 to (1) allow a better assessment of the post-treatment effects of fire and fire surrogate treatments on small mammal populations, and (2) identify the potential limitations of our data to enable improvements to subsequent data collection efforts.

FIRE EFFECTS ON CRYPTOBIOTIC SOIL CRUSTS IN THE GRAND STAIRCASE-ESCALANTE NATIONAL MONUMENT, UTAH

Paul Evangelista, Debra Guenther, Thomas J. Stohlgren, and S. Stewart

Cryptobiotic soil crusts are microorganisms found in the soil surfaces of semiarid and arid regions throughout the Colorado Plateau; they are common in the Grand Staircase-Escalante National Monument in Utah (U.S. Department of Interior 1999). Crusts may range from minor ridges less than 1 $\mathrm{cm}$ in height to highly developed pedicles 3-6 cm high. Crusts in the monument are predominantly cyanobacteria (Microcoleus vaginatus), algae (> 40 species), lichens (dominated by Collema tenax and C. coccophorum), and mosses (Syntrichia caninervi and S. ruralis being the most common), but they are 
also known to contain taxa of liverworts, fungi, and bacteria (Johansen et al. 1984; Evans and Johansen 1999; Belnap and Lange 2001). Concentrated in the top 1-4 mm of soil, they primarily affect processes that occur at the land surface or soil-air interface (Belnap and Lange 2001). The functions that crusts are believed to play in these ecosystems include soil stability and erosion control from wind and water, atmospheric nitrogen-fixation, nutrient contributions to plants, positive soil-plant-water relations, infiltration processes, germination enhancement, and plant growth (Anderson et al. 1982a, 1982b; Belnap and Gardner 1993; Belnap and Harper 1995; Belnap and Gillette 1998).

Cryptobiotic crusts are well adapted to severe growing conditions; however, they are extremely vulnerable to compressional disturbances such as livestock grazing, recreation, and vehicle tracks (Belnap 1996, 1998). A study by Belnap (1996) found that crust disturbance may reduce nitrogenase activity by 30-100 percent. Consequently, anthropogenic surface disturbances may have serious implications for nitrogen budgets in these ecosystems, resulting in change of vegetative species composition (Belnap 1995; Evans and Belnap 1999). Additionally, loss of crusts can result in decreased water availability to vascular plants, accelerated soil loss through wind and water erosion, and decreased diversity and abundance of soil biota (Belnap 1995). Recovery rates for cryptobiotic crusts are generally very slow. Crust cover has been observed by Anderson et al. (1982a) to increase up to 15 percent in the first 14-18 years after compaction, but only 1 percent during the following 20 years. However, nonliving remnants of cryptobiotic crusts may still retain their pedicles and continue to bind soil particles, which may still be advantageous for soil stabilization and increasing moisture retention (Belnap and Gardner 1993).

\section{VEGETATION CHANGES IN A RIPARIAN COMMUNITY ALONG THE DOLORES RIVER DOWNSTREAM FROM MCPHEE RESERVOIR IN SOUTHWESTERN COLORADO \\ David Kriegshauser and Preston Somers}

Moisture is one of the premiere limiting factors for plants and animals, and where moisture is not limiting - in streams, marshes, lakes, and the land areas adjacent to these features (the riparian zone) - one finds very distinctive communities of water-dependent and drought-intolerant species. Major streams in the foothills and basins of the San Juan region are commonly lined with riparian woodlands dominated by cottonwoods (Populus spp.). These woodlands and associated phreatophytic vegetation (composed of plants that require a perennial water source near the soil surface) have changed dramatically during the latter half of the nineteenth and the twentieth centuries on the western Great Plains and in the southwestern United States. Much of the change results from the fact that riparian areas are the ones that were first settled and developed for city and town sites, farmlands, and residential areas. Vast areas of riparian communities have been cleared or modified beyond recognition. We have recently seen significant but more subtle changes in the remaining riparian communities that were once thought to be "wild" or "natural." Here the most common pattern is the decline of the native cottonwoods and their replacement by native riparian shrub species such as sandbar willow (Salix exigua) or exotic phreatophytes such as tamarisk or saltcedar (Tamarix ramosissima) and Russian olive (Elaeagnus angustifolia; Miller and Bowman 1985; Howe and Knopf 1991).

These changes are commonly attributed to the construction of dams, water storage reservoirs, and irrigation diversion projects upstream of the affected areas. Such constructions and their typical management regimes regulate stream flow at a relatively constant year-round level and drastically reduce spring and early summer snowmelt flows. Thus the riparian areas downstream of these water storage and management projects are no longer subjected to periodic scouring of the riverbanks and terraces. By eliminating this natural form of disturbance and stabilizing the riparian environment, these human developments have severely impaired the reproduction of cottonwoods and have allowed 
shrubby phreatophytes to invade sites adjacent to the river channel that were previously bare or supported cottonwood seedlings (Johnson 1992; Fenner et al. 1985).

\section{IDENTIFYING INDICATORS OF ECOSYSTEM HEALTH FOR A SEMIARID ECOSYSTEM: A CONCEPTUAL APPROACH}

Tischa A. Muñoz-Erickson, Matthew R. Loeser, and Bernardo J. Aguilar-González

Managers of public and private lands face a challenging dilemma. With finite and often limited resources, these individuals are being asked to manage for sustainability, but the definition of sustainability is typically user-defined, and ultimately vague. In cases where so-called objective approaches have been employed, the emphasis has been on ecological science that often ignores both the role and effects of humans in managed ecosystems (Liu 2001). These ecosystems are subjected to a high degree of environmental variability and anthropogenic disturbance; thus, assessing their condition must reflect their inherent complexity (Haskell et al. 1992). For example, in agricultural ecosystems, there has been a growing recognition that ecology needs to be integrated with economics to achieve long-term sustainability (Aguilar 1999; Crews et al. 1991). Therefore, achieving sustainability in managed ecosystems requires an expanded approach that hybridizes the "hard sciences" that develop an understanding of the structure and function of ecosystems, with the "soft sciences" that focus on social and economic understanding of human communities (Allen and Hoekstra 1992).

The appropriate management of semiarid ecosystems has generated substantial debate because these areas are typically rich in biological diversity and human use. The landscapes of the southern Colorado Plateau have been subjected to a broad array of land uses since the settlement of EuropeanAmericans, including, but not limited to urban development, crop agriculture, livestock grazing, recreation, off-road vehicles, and total preservation (to the point of preventing natural events such as fire and flooding). Perhaps the most pervasive land-use practice on semiarid ecosystems has been the grazing of domestic livestock and its associated land-management practices (Fleischner 1994). Issues like livestock grazing remain politically contentious, not necessarily because we lack sufficient ecological knowledge, but more likely because we lack adequate integration of the ecological and social effects of choosing a grazing policy (Sisk et al. 1999; Loeser et al. 2001; Jemison and Raish 2000). Given the highly political atmosphere and uncertainty in managing semiarid ecosystems, managers need an analysis that combines general theoretical information on rangeland vegetation dynamics, sitespecific parameters applied to a real context, and implications relevant to the scale and dimension of the "management space" they are working in (Archer et al. 1999). In this paper we employ the concept of ecosystem health and integrated indicators as a method to monitor and evaluate the effects of management decisions.

\section{A COMPARISON OF A NEAR-RELICT SITE AND A GRAZED SITE IN A PINYON-JUNIPER COMMUNITY IN THE GRAND STAIRCASE-ESCALANTE NATIONAL MONUMENT, UTAH Debra Guenther, Thomas J. Stohlgren, and Paul Evangelista}

Few areas in the American West have been left ungrazed or undisturbed by cattle, sheep, or goats. However, isolated mesa tops in the Colorado Plateau area offer a rare glimpse of what ecosystems might be like without the influence of domestic livestock; these areas are extremely valuable for research (Van Pelt and Tuhy 1991). Despite their value as control sites, difficulties remain in using these areas for comparative studies. Such sites are often extremely rocky and contain little vegetation. It is also challenging to find paired grazed sites with similar geology, slope, aspect, and vegetation type. Truly pristine sites may be difficult to find, but sites grazed in the distant past can still provide insight into grazing effects and subsequent recovery. 
Several studies have examined the effects of grazing by comparing an isolated area to a nearby "mainland" area that has been grazed (Schmutz et al. 1967; Kleiner 1983; Madany and West 1983, 1984; Jeffries and Klopatek 1987; Beymer and Klopatek 1992). Mandany and West (1984) studied mixed conifer, ponderosa pine (Pinus ponderosa), and Gambel oak (Quercus gambelii) woodlands on two relict mesas in Zion National Park, and concluded that perennial herbaceous species were much more common on the relict mesas than on a nearby grazed plateau. In addition, livestock grazing was considered to be the primary cause for the increased growth in woody species on the grazed plateau due to decreased competition with grass species (Madany and West 1983). In Grand Canyon National Park, Boysag Point had been grazed by sheep between 1920 and 1943 but has since been ungrazed. Despite the earlier grazing disturbance, perennial grasses had 36 percent cover on the Point compared to the mainland with 6 percent cover, and juniper (Juniperus monosperma) trees were significantly more dominant on the mainland (Schmutz et al. 1967).

Grazing comparison studies have also examined cryptobiotic crust cover. Fragile crusts contribute to the Colorado Plateau ecosystem by increasing soil stability, fixing atmospheric nitrogen in the soil, and increasing infiltration (Anderson et al. 1982a; Belnap and Gillette 1998). Jeffries and Klopatek (1987) have studied blackbrush community types in southern Utah and northern Arizona. They found slow recovery of cryptobiotic crusts even after light grazing when compared to a relict mesa. Cryptobiotic crusts in pinyon-juniper communities in Grand Canyon National Park, which also suffer from grazing, were reduced by 80 percent on a grazed site $(5.2 \%)$ compared to a relict site (23.3\%; Beymer and Klopatek 1992). Other studies have focused on the vegetation or soils of a particular relict or near-relict mesa. Thatcher and Hart (1974) studied vegetation differences based on soil types on Spy Mesa in northern Arizona. Fishtail Mesa in Grand Canyon National Park was studied by Jameson and his colleagues in 1957 (Jameson et al. 1962), and the sampling was repeated 38 years later (Rowlands and Brian 2001). No Man's Mesa in southern Utah was surveyed in the mid1960s by Mason et al. (1967).

\section{BALD EAGLE ABUNDANCE AND RELATIONSHIPS TO PREY BASE AND HUMAN ACTIVITY ALONG THE COLORADO RIVER IN GRAND CANYON NATIONAL PARK, ARIZONA Charles van Riper III and Mark Sogge}

Bald eagles (Haliaeetus leucocephalus) are found throughout North America and into northern Mexico (Buehler 2000). Although common breeders in Alaska and parts of Canada, bald eagles are far less numerous in the lower 48 states, where they still face a variety of anthropogenic-related threats. In 1995 the U.S. Fish and Wildlife Service down-listed the bald eagle from endangered to threatened status in the lower 48 states (U.S. Fish and Wildlife Service 1995). The Arizona Game and Fish Commission formerly listed the bald eagle as endangered (Arizona Game and Fish Department 1988), but presently the bird has no state status.

During winter, bald eagles in North America migrate to southern latitudes (McClelland et al. 1994). Although large wintering concentrations are rare in the Southwest, bald eagles are found scattered throughout Arizona, where statewide counts have increased from 225 in 1992 to 440 in 2001 (Beatty 2001). Most wintering eagles concentrate along rivers, lakes, and reservoirs where preferred prey (e.g., fish, carrion, and waterfowl) is found (Grubb and Kennedy 1982), and they return each year to the same wintering locations (Harmata and Stahlecker 1993). Bald eagles are also found at roosts in forested areas of Arizona (Grubb et al. 1989).

Each winter, bald eagles concentrate along the Colorado River corridor in the Grand Canyon, primarily from Glen Canyon Dam downstream to the confluence of the Little Colorado River. In some years, the Colorado River corridor of Grand Canyon National Park hosts one of the largest 
concentrations of wintering bald eagles in Arizona, and indeed the entire Southwest (Brown et al. 1989). From November through March, eagles forage along the Colorado River (Figure 1), primarily from Glen Canyon Dam at River Mile (RM) - 15.5 to the confluence with the Little Colorado River (RM 61.5). During the winter of 1991, up to 23 eagles were counted within this river stretch (Brown and Stevens 1992). Bald eagles are also regularly observed by people on Colorado River rafting trips from November through March. Such evidence clearly demonstrates that this portion of the Colorado River corridor is used extensively by wintering bald eagles.

Bald eagles utilize the main Colorado River corridor and tributaries where rainbow trout (Salmo gairdneri) are spawning. One such tributary is Nankoweap Creek, where bald eagles have concentrated since the early 1980s (Brown et al. 1989; Leibfried and Montgomery 1993). Beginning in 1987, when six bald eagles were observed at the Nankoweap Creek delta, these birds have become the focus of much study in the Grand Canyon. Eagle counts at Nankoweap began in 1988 (Brown et al. 1989), when the number peaked at 18 birds. In 1990 and 1991, a team from the National Park Service Cooperative Park Studies Unit and Northern Arizona University conducted intensive studies of creek morphology and flow, trout abundance, movement, morphology, and reproduction, bald eagle abundance and foraging ecology, and human disturbances.

\section{RELIABILITY OF INFRARED SURVEYS FOR DETECTING AND ENUMERATING TURKEYS WITHIN FORESTED HABITATS IN NORTH-CENTRAL ARIZONA \\ Brian F. Wakeling, Ronald W. Engel-Wilson, and Timothy D. Rogers}

Monitoring turkey populations is important because many recreational and land management practices impact turkey habitat (Healy and Powell 1999). Despite several advances in survey methodology, turkey populations remain difficult or expensive to index effectively. Direct winter counts (visual enumeration at winter roost sites) may be the only effective census method for turkeys, and the application of this technique is effective only because turkeys tend to form stable winter flocks (Porter 1978), use the same roosting sites repeatedly (Cook 1973; Wakeling 1997), and restrict their movements during periods of heavy snow cover (Hayden 1980). This technique does not lend itself well in areas where winter snowfall is irregular or turkeys have a wide selection of roosting areas. Estimates may be derived from transect or plot sampling approaches, but assumptions of randomness in sampling and standard observabilities are difficult to meet (Healy and Powell 1999). For instance, roadside surveys are commonly employed for this type of sampling, but roads are not randomly distributed throughout habitats occupied by turkeys and these surveys can be insensitive to relatively large changes in population size (Shaw 1973). Furthermore, turkeys routinely occupy several habitat types with differing visual obscurity (e.g., meadows and dense forest). Mark-recapture techniques can be costly in terms of dollars and human resources (Healy and Powell 1999).

Because contemporary resource management requires increasingly precise and accurate information to monitor responses, we investigated the performance of aerial infrared technology to detect and enumerate turkeys. Aerial infrared surveys have become popular in the scientific wildlife management literature because they seem to standardize observer bias and objectively survey large wildlife species with suitable accuracy (Wiggers and Beckerman 1993; Garner et al. 1995; Naugle et al. 1996; Adams et al. 1997; Havens and Sharp 1998). Hansen and Beringer (1997) summarized the limitations of aerial infrared surveys as the (1) inability to consistently differentiate between target wildlife and the background, (2) inability to differentiate among species, (3) presence of forest canopy that retards the detection of infrared radiation, and (4) high cost. Recent literature (Wiggers and Beckerman 1993; Garner et al. 1995; Naugle et al. 1996) has suggested that advances in infrared technology have overcome some of the limitations (i.e., identification and differentiation have 
improved) that have historically reduced the effectiveness of infrared wildlife surveys. We tested the reliability of infrared surveys in detecting and enumerating turkeys within forested habitats in northcentral Arizona. Because we expected reliability to be influenced by changing temperatures and degrees of obscurement, we conducted infrared tests that varied in time of day and canopy closure to determine the degree of influence these factors have within ponderosa pine forests commonly occupied by Merriam's turkeys in Arizona.

\section{CONCEPTUAL FRAMEWORK FOR STUDYING THE EFFECTS OF FUELS TREATMENTS ON AVIAN COMMUNITIES IN PONDEROSA PINE FORESTS OF NORTHERN ARIZONA Brett G. Dickson, William M. Block, and Thomas D. Sisk}

Many ponderosa pine (Pinus ponderosa) forests in the western United States are dense and have accumulated large amounts of ground and ladder fuels, resulting in forests at high risk of catastrophic fire (Cooper 1960; Harrington and Sackett 1990; Swetnam 1990; Covington and Moore 1994; Whelan 1995; Allen et al. 2002). Indeed, recent wildfires that occurred throughout the intermountain West during the spring and summer of 2000 attest to the volatility of the situation, and many forest ecologists and fire officials agree that steps must be taken to reduce fuel levels and abate the risk of large-scale, stand-replacing wildfire (Allen et al. 2002; Arno and Allison-Bunnell 2002). Two potential tools that can be used to abate fire risk are prescribed fire and thinning, used singly or in combination. However, the effects of applying these tools on various ecosystem attributes are not well understood (Tiedemann et al. 2000; Wagner et al. 2000). To address this knowledge gap, the national Fire and Fire Surrogates (FFS) program seeks to quantify the effects of prescribed fire and thinning on a set of response variables, including wildlife.

In the Southwest, the general objective of this program is to evaluate the effects of these fuels treatments on wildlife in ponderosa pine forests of northern Arizona and northern New Mexico. Specifically, as part of this program, our objectives are to examine treatment effects on (1) avian community structure, (2) avian foraging patterns, and (3) small mammal demography and community structure. This paper focuses on pre-treatment data collected on avian community structure (namely, bird species richness and abundance) and avian foraging patterns in northern Arizona as our "first tier" of the initial program efforts. Ultimately, the data collected from this study will be combined with similar data collected at other research sites from this national program to examine general patterns common to long-needle pine ecosystems.

The experimental design for the national project calls for three experimental treatments (thinning of small trees, prescribed fire, and thinning followed by prescribed fire) and a control, each implemented in 10 ha measurement blocks (with suitable treated buffer around the measurement blocks $=$ treatment unit), replicated three times on a study area (C. P. Weatherspoon, unpublished report). Whereas this design allows a standardized and cost-effective approach to be implemented nationwide, the relatively small block size, combined with the vagility of the study taxa, introduces questions concerning the movements and behavior of individual organisms within and between the treatment units. This is of particular concern in arid southwestern ponderosa pine forests which are relatively unproductive and where animal densities tend to be low. The small size of our treatment units restricts the number of individuals detected (i.e., samples) of most species, thereby limiting sample sizes, statistical power, and the ability to draw conclusions. Therefore, problems inherent to the basic FFS design require innovative approaches to maximize the amount of useful information that can be derived from the study. 
Proceedings of the Sixth Biennial Conference

FIRST-YEAR RESULTS OF THE ONGOING PALEONTOLOGICAL INVENTORY OF PETRIFIED FOREST NATIONAL PARK, ARIZONA

William G. Parker and Sue Clements

Petrified Forest National Park (PEFO) in northeastern Arizona contains some of the premier exposures of Late Triassic terrestrial sediments in the world. The majority of these sediments are fluvial in origin, belonging to the Petrified Forest Member of the Chinle Formation, and are Late Carnian through Early-(Middle?) Norian in age. The park is renowned for its fabulous preservation of numerous fossil logs, but park sediments also preserve diverse vertebrate and invertebrate faunas, along with abundant plant and trace fossil records, providing an excellent template for the Late Triassic ecosystem.

The first paleontological work in the PEFO area consisted of preliminary studies of fossil trees, beginning with the Whipple Expedition of 1853, which produced the first description of the petrified wood deposits (Figures 1 and 2). Almost 50 years later, a paleobotanist with the U.S. Geological Survey, Lester Ward, performed a reconnaissance of the area. Ward recognized both the significance of the deposits and the dangers facing them and recommended their preservation (Ash 1972b). On December 8, 1906, President Theodore Roosevelt created the Petrified Forest National Monument to protect these unique paleontological resources for future study.

Although the legendary John Muir collected vertebrate fossils from the "forests" in the early twentieth century, Charles L. Camp of the University of California at Berkeley (UCMP) was the first to conduct extensive collection and documentation of vertebrates in the area of the park, starting in 1921 and continuing for almost a decade (Long and Murry 1995). This work culminated with an extensive monograph on the phytosaurs published in 1930 in which Camp stressed the biostratigraphic utility of vertebrate fossils in Late Triassic sediments of the American Southwest. Camp (1930) was the first to document distinct vertebrate faunal zones in the Chinle Formation, which influenced the modern biostratigraphic systems of Long and Ballew (1985) and Lucas (1998). Spurred by Camp's success, Edwin H. Colbert of the American Museum of Natural History and Charles W. Gilmore of the U.S. National Museum conducted fieldwork in the 1930s and 40s. Unfortunately other projects, most notably Colbert's discovery of the Ghost Ranch Quarry in 1947, ultimately kept both parties from doing more extensive work in the park, but small yet significant collections were made by each institution. Colbert was also very interested in the erosional rates of the Chinle Formation because on several noted occasions he had uncovered vertebrate fossils completely destroyed by summer rainstorms (Colbert 1946). In 1951 he placed a series of sharpened wooden stakes in the mudstones of the Tepees area and returned periodically to monitor the amounts of erosion (Colbert 1956, 1966). During the next few decades paleontological work in the park was conducted mainly by park naturalists, with research concentrating heavily on paleobotany. This emphasis was spurred by the discovery of the first leaf fossils from the area in 1932 during construction of the present park.

\section{AN INVENTORY OF PALEONTOLOGICAL RESOURCES ASSOCIATED WITH CAVES IN GRAND CANYON NATIONAL PARK \\ Jason Kenworthy, Vincent L. Santucci, and Kenneth L. Cole}

Strategies to better document occurrences of paleontological resources within units of the National Park Service were developed by the NPS Geologic Resources Division during the late 1990s in response to the Natural Resource Challenge. The primary objective for these inventories is to compile baseline paleontological resource data to enhance the scientific understanding and management of these nonrenewable resources.

The first inventory strategy is designed to survey all occurrences of fossils, including plants, invertebrates, vertebrates, and trace fossils, within each park. This comprehensive park-level strategy 
was piloted at Yellowstone National Park in 1996 (Santucci 1998). The Yellowstone survey, as well as subsequent comprehensive inventories, involved literature review, examination of museum collections, and extensive field inventories.

The second inventory strategy involves the development of thematic paleontological resource inventories throughout the NPS. Thematic inventories focus on one category of fossils and attempt to locate which units of the NPS preserve this type of resource. The first thematic resource inventory identified park units that contain fossil vertebrate tracks (Santucci et al. 1998). The Grand Canyon research summarized in this report was conducted as part of a thematic resource inventory identifying paleontological resources associated with caves in the NPS (Santucci et al. 2001). Cave and karst features are a significant resource in the NPS, with more than 3600 such features documented in at least 79 units, 35 of which preserve paleontological resources in caves (Santucci et al. 2001).

\section{PALEOURINE ANALYSIS OF PACKRAT AMBERAT}

\section{Nancy E. Muleady-Mecham}

The use of packrat (Neotoma) middens (Figure 1) for reconstruction of paleoenvironments has been a vital tool for many decades. Packrat urine has been studied from captive rats in labs and from the modern habitation of the rats known as middens. Middens are fortress-like structures that include a packrat's nest, food storage, and immediate abode. Middens are often indurated and cemented together with the urine of packrats. Modern rodent urine was initially studied for its microcrystalline content (Emerson and Hoffman 1978; Shirley and Schmidt-Nielsen 1967), and later for its pheromone content (Ingram 1987). Packrat urine has been found as a part of consolidated middens that are older than 30,000 years before present (yr BP).

Phil Orr first described the "glue" that held middens together (Orr 1957); recognizing the yellowish hardened substance as packrat urine, he named it "amberat." These indurated or cemented middens were somewhat more protected from the elements than unconsolidated middens, and helped preserve the macrofossils (Fall et al. 1990; Finley 1990). In modern middens, packrat urine has been described as brown, dark brown, and yellow to white. Urine on and in the midden inevitably holds the midden together, and packrats often urinate at specific places, called "posts" (Emerson and Hoffman 1978; Vaughn 1990). Microcrystalline analysis of this modern urine has indicated the presence of calcite, oxalate, calcium carbonate monohydrate, styruvate, amorphous material, detrital silicates, and weddelite (Emerson and Hoffman 1978). Similarly, tolerance of the poison, oxalate, ingested by packrats has been studied along with its effects on hamsters (Mesocricetus), sand rats (Psammomys), and Osborne-Wendell laboratory white rats (Rattus). Results of these experiments by Shirley and Schmidt-Nielsen (1967) showed that hamsters and packrats, especially the latter, had the ability to tolerate the poisonous oxalate, and to absorb calcium for use from insoluble calcium oxalate. This source of calcium (vital for muscle contraction, nerve transmission, and bone and teeth formation) was speculated to be available due to symbiotic microbes in the intestinal tract. Adaptation by packrats to tolerate and ultimately make use of this form of oxalate is probably due to the large proportion of oxalate-containing Opuntia cactus in many Neotoma diets (Schmidt-Nielsen 1979; Hekmati 1989; Vaughn 1990; Alvarez-Castaneda et al. 1991; Carraway and Verts 1991). Modern packrat middens and urine posts are often streaked with a creamy white substance, which is calcium carbonate, a byproduct of the rats metabolizing calcium oxalate from the ingestion of cactus containing the substance (Shirley and Schmidt-Nielsen 1967; Emerson and Howard 1978; Carraway and Verts 1991). Packrats obtain their water from the free water available in succulent plants, such as juniper (Juniperus), sage brush (Artemisia), and cactus (Opuntia). Packrats have become ill and died in the laboratory when provided with dry food and freestanding water; they rely heavily on water from the food source itself (Schmidt- 
Nielsen 1979; Cornely and Baker 1986; Macedo and Mares 1988; Carraway and Verts 1991; AlvarezCastaneda and Yensen 1999).

\section{PREVENTING ZEBRA MUSSEL INFESTATION AT LAKE POWELL} Mark Anderson and John Ritenour

Zebra mussels (Dreissena polymorpha) and quagga mussels (D. bugensis) are small striped invasive bivalves. They constitute one of the greatest threats to water resources in the western United States, having already spread throughout much of the eastern United States. The genus Dreissena is unique among freshwater mussels in that they can attach to surfaces using byssal threads, which allows them to build up mats that can reach more than $30 \mathrm{~cm}$ in thickness. Zebra mussel mats can form within pipes, reducing or clogging their flow. These mussels will encrust docks, launch ramps, rocks, and any hard surfaces in the water. Industries in infested areas spend billions of dollars every year to remove zebra mussels from raw water related structures (O’Neill 1996).

Native to the Caspian and Black Seas of Eastern Europe, zebra mussels had spread throughout Europe by 1920, with the creation of canals and the increased capacity of humans to spread the mussel. It was recognized at that point that their havoc could be spread to the United States in the ballast water of commercial ships. They were first discovered in America in 1988, amongst the Great Lakes in Lake Saint Clair. Since then, they have spread throughout the Great Lakes and into eight major river systems.

The zebra mussel life cycle progresses from a tiny egg stage to a veliger and postveliger stage, which are all planktonic. After the post-veliger stage, they enter a settling stage when the production of a shell makes them too dense to float. The forming mussels begin to sink and seek a substrate upon which to attach. The passage from the egg to the settling stage requires $2-3$ weeks. After settling, zebra mussels can detach, move around, and reattach as they grow up to $3 \mathrm{~cm}$ long and live 4-5 years. Some zebra mussels in Europe have been reported to live up to 9 years (Marsden 1992). They become sexually mature after the first year and each female can reportedly produce up to a million eggs annually.

Zebra mussels have a great impact on recreation. Boats left in the water will develop a layer of zebra mussels on their hulls and engines. Microscopic veligers can enter, attach, and clog the cooling systems of engines. Beaches can become covered with piles of shells washed up by wave action. The shells have sharp edges that can cut bare feet. The shells also carry bits of zebra mussel flesh that stink as they decompose. In addition to the costs to industry and recreation, zebra mussels cause a great deal of ecological damage. There have been no successful eradication attempts. Any known strategy to kill zebra mussels in the environment will also destroy other forms of aquatic life. Zebra mussels will encrust crayfish, turtles, and native clams. They show a preference for attaching to other mussel shells, inhibiting their shells from opening or closing and thus killing them. Zebra mussels filter an enormous amount of water, removing large quantities of algae, thus disrupting the food chain. Undigested food is packed into a ball of mucous and ejected as a pseudo-fecal pellet. These pellets can form thick layers beneath infestations, creating a large oxygen imbalance that can kill fish.

\section{MULTI-OBJECTIVE ANALYSIS OF THE PROPOSED REROUTING OF THE RIO DE FLAG IN FLAGSTAFF, ARIZONA \\ Boris Poff and Aregai Tecle}

The Rio de Flag, which drains the southern portion of the San Francisco Mountains, is an important part of the city of Flagstaff, which is located at the base of the mountain. According to the Rio de Flag Draft Feasibility Report and Environmental Impact Statement (U.S. Army Corps of Engineers 2000), flooding is a major problem in the area. A 100-year flood event would inundate a large area, 
damaging various resources and facilities, such as streets, railroad tracks, commercial and industrial properties, educational facilities, and residential homes. Because there are no flow gages, the U.S. Army Corps of Engineers based their flood hazard analysis on information obtained from newspapers, recollections of city officials, statements from Flagstaff senior residents, Northern Burlington Santa Fe Railroad files, and other sources. The U.S. Army Corps of Engineers and the city of Flagstaff officials agree that some preventative action must be taken; the city may otherwise continue to incur significant economic, social, and environmental damages from severe floods.

Approximately 1500 existing structures worth about 385 million dollars are prone to flood damage, and may sustain about 93 million dollars of damages from a 100-year flood event (U.S. Army Corps of Engineers 2000). Further, a significant portion of Northern Arizona University lies within the 100-year floodplain, and during any flood events that exceed this amount, the university may incur significant damages and disruptions in its regular activities. For these reasons, any flood control project along the Rio de Flag should be evaluated with criteria that consider the various effects of any channel improvement project on the Flagstaff community and its environment. The desires and aspirations of the community as well as other attributes of general interest in the area are expressed in terms of seven general objectives and their specifications. The specifications are quantifiable details of the general objectives that can be expressed in terms of measurable criteria. Altogether 15 feasible alternative channel improvement projects, including a no-action option, are evaluated with respect to 30 criteria. The result is the design of a more inclusive decision-making process that identified the most-preferred project from among the feasible alternatives. The procedure also allows interactions among interested parties in the selection of the most satisfactory alternative project.

\section{EVIDENCE OF THE SIGNATURE OF NORTH PACIFIC MULTIDECADAL PROCESSES ON PRECIPITATION AND STREAMFLOW VARIATIONS IN THE UPPER COLORADO RIVER BASIN}

Hugo G. Hidalgo and John A. Dracup

The objective of this study was to show evidence of linkages between hydroclimatic variations in the Upper Colorado River Basin (UCRB) and the north Pacific multidecadal climatic signal present in the Pacific Decadal Oscillation (PDO).

The El Niño-Southern Oscillation (ENSO) and the PDO explain a large fraction of hydroclimatic variability in North America (for a list of references see Hidalgo and Dracup 2003). In the western United States, ENSO teleconnections are strong when the southern oscillation index (SOI) and NIÑO3 SST region are out of phase and PDO is negative (McCabe and Dettinger 1999). In the case of the UCRB, studies have shown drier than average conditions in the northern part of the basin, and wetter than average conditions in the southwestern part of the basin during El Niño years (Cayan and Webb 1992; Clark et al. 2001; Hidalgo and Dracup 2003). Another study showed an unusually coherent ENSO signal in warm-season precipitation along with an ENSO signal on cold-season precipitation in the high-elevation regions (Hidalgo and Dracup 2003).

The north Pacific is known to modulate climate in North America at multidecadal time scales (Gershunov and Barnett 1998). Changes in mean climatic conditions over relatively short periods of time, known as climatic regime shifts, associated with the multidecadal mode have been observed in physical and environmental variables around North America (Ebbesmeyer et al. 1991; Trenberth and Hurrell 1994; Mantua et al. 1997; Weinheimer and Cayan 1997; Wiles et al. 1998). The climate variations associated with the north Pacific mode are evident in November to March averages of the north Pacific (poleward of $20^{\circ} \mathrm{N}$ ) sea surface temperature (SST) leading principal component (PC) designated the Pacific Decadal Oscillation (PDO) index by Mantua et al. (1997). Sign reversals of the 
PDO index in 1924/25, 1946/47, and 1976/77 impacted physical and environmental variables around the North American coast (Mantua et al. 1997).

In the following sections, evidence of teleconnections between the UCRB and north Pacific climatic variations is presented. This evidence is compared to climatic variations in the Pacific North American coast, a region located closer to the north Pacific multidecadal mode (NPMM) influence, and presumably strongly affected by these oscillations. Multidecadal to centennial variations were studied using dendrochronological information to characterize the evolution of these variations beyond the period covered by instrumental records. 


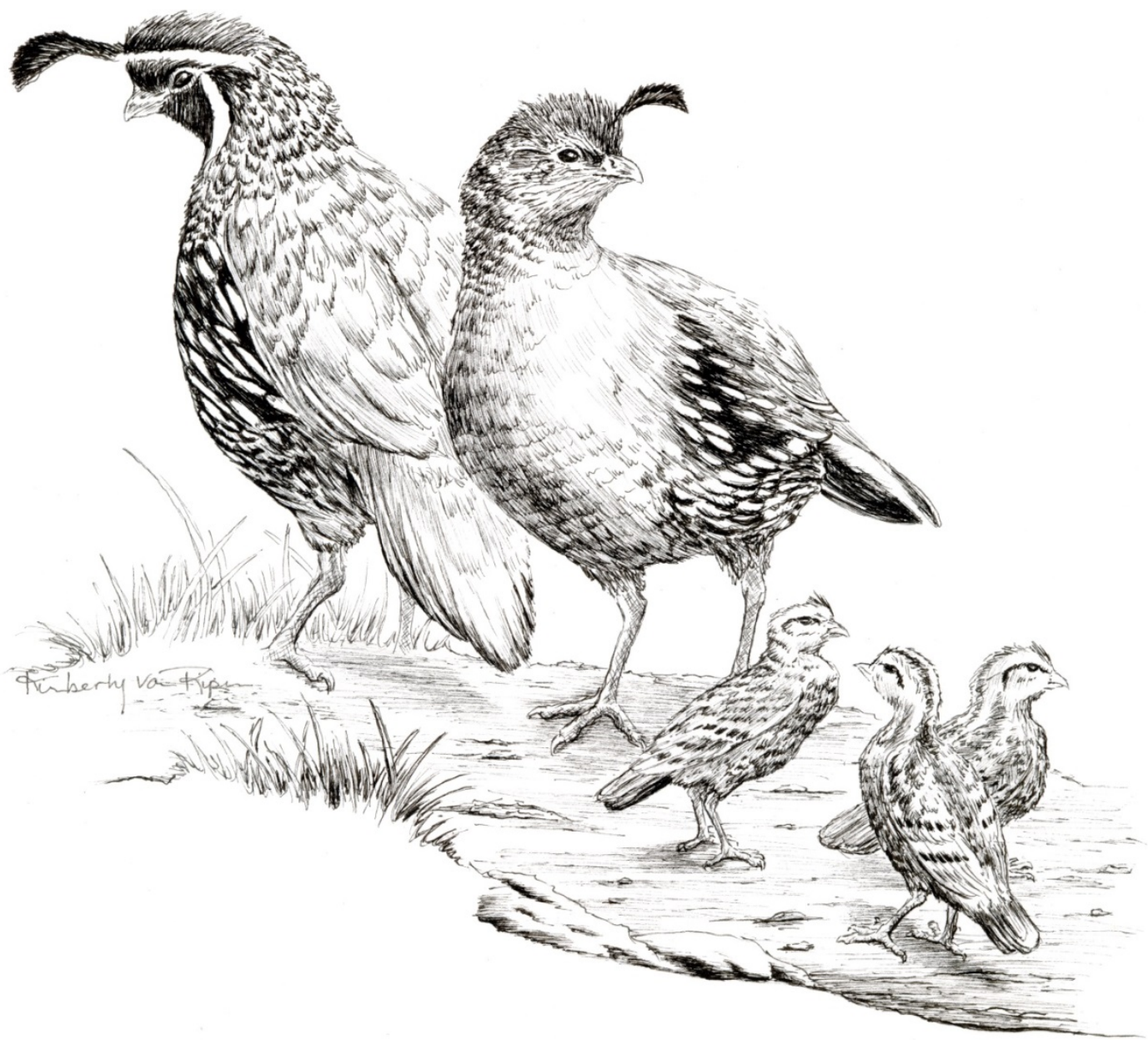

Drawing of Gambel's quail, Callipepla gambelii, family group (copyright and courtesy of Kimberly Ann van Riper). 


\title{
Proceedings of the Seventh Biennial Conference of Research on the Colorado Plateau: Biophysical, Socioeconomic and Cultural Research on the Colorado Plateau
}

\author{
Edited by Charles van Riper III and David J. Mattson
}

This is the seventh volume, and the second published by the University of Arizona Press, in a series of books that focus on research and resource management issues on the Colorado Plateau. These books highlight the integration of research into resource management efforts, as related to cultural, natural, and physical resources within the biogeographic province of the Colorado Plateau. This particular volume integrates aspects of biophysical and socioeconomic research through a mix of chapters that address management issues on the Colorado Plateau.

The scientific works published in this Biennial Conference Series contribute significantly to presenting peer reviewed results of collaborative efforts between scientists and land managers. Many of the protocols and management techniques presently being utilized in land management units over the Colorado Plateau are a result of these collaborative works, including those of the U.S. Geological Survey Southwest Biological Science Center staff with university and other partner agency scientists, and with land managers from a variety of state and federal agencies. It has been clearly demonstrated that, because of similarities across the Colorado Plateau, techniques that work in one management unit are applicable to many other areas. This is due primarily to the similarity of habitat and climatological conditions over the Colorado Plateau.

The 29 chapters in this book were selected from the 116 research papers presented at the Seventh Biennial Conference of Research on the Colorado Plateau. Held 5-8 November 2003 in Flagstaff, Arizona, the conference was hosted by the U.S. Geological Survey Southwest Biological Science Center's Colorado Plateau Research Station (CPRS) and the Center for Sustainable Environments at Northern Arizona University. The meeting theme revolved around research, inventory, and monitoring of lands over the Colorado Plateau, with a focus on aspects of biophysical and socioeconomic research.

Every paper that was selected for publication represents original research that has been peer reviewed by at least two scientists from that research discipline. Material presented in this book is information that has not been previously published in any other location. The 29 contributed studies each constitute a separate chapter. The book is divided into four sections: Socioeconomic, Biological, Cultural, and Biophysical.

The book begins with Socioeconomic Considerations. The opening chapter by Hecox and Holmes, from Colorado College, sets the stage for a theme that is carried throughout many of the chapters in this book, that of tying social and economic criteria into the management of resources over the Colorado Plateau. The chapter covers aspects of shifting socioeconomic patterns and resulting disparities over the Colorado Plateau. The authors focus on changes within the past three decades, examining data on population number increases and types of employment from 31 counties of four states. One benchmark that they feel has created the present disparity over the Colorado Plateau has been the shift in employment type. They demonstrate, through the use of location quotient and mixshare analyses that employment over the Colorado Plateau has shifted into resource-based jobs, manufacturing and the service industry. Concomitantly, there has been an employment shift away from the former heavy dependence on natural resource extraction. They conclude the chapter by 
recommending that future economic development on the Plateau focus on attracting higher-end producer services along with the self-employed and small-scale businesses. They feel that the spectacular natural and cultural resources of the Colorado Plateau will continue to serve as a focal draw to the region, thus ultimately influencing all facets of the economy and political datums from which the present modern biogeographical pattern is based.

Chapter \# 2 presents survey results on perceptions of socioeconomic impacts of forest restoration policy over the Colorado Plateau. Ostergren and Ruther surveyed a random sample of residents in the northern Arizona region regarding their acceptance of various physical forest conditions. The authors also determined if the surveyed residents were in agreement with different forest restoration and decision-making strategies. Basic demographic data was gathered from respondents, which allowed for judgments regarding sample bias. Although the authors found that respondents supported some restriction on appeals of administrative decisions, support was even stronger for continued and increased public involvement in official decision-making. Ostergren and Ruther's other key findings included preference for information from the U.S. Forest Service and newspapers compared to from other sources, and support for forest restoration goals other than commercial timber production, but with an acceptance of permanent dirt roads and logging operations. They close the chapter by urging ongoing appraisal of public perspectives with an emphasis on reaching poorer and minority residents who were under-represented in their initial survey.

Chapter \#3 by Ruther and Ostergren provides results of another survey of northern Arizona residents, this one focused on perceptions and knowledge of mountain lions, which are currently a focus of controversy throughout the western U.S. The authors found that almost all respondents thought it was important for mountain lions to be in Arizona, and that mountain lions played an important ecological role. However, older rural residents were substantially less accepting of mountain lions compared to younger urban residents. Ruther and Ostergren point out that the majority of respondents preferred nonlethal devices for personal protection from lions and that anxiety about encountering mountain lions was actually greater for those who had never seen one, when compared to those respondents who had a previous lion encounter. The majority of respondents also preferred non-lethal resolution of conflicts between humans and mountain lions and limiting human development in prime lion habitat, which suggests considerable public support for conservation at a time of increasing human impacts

The Socioeconomic section of this book concludes with Chapter \#4 by Hampton et al., who provide a demonstration and test of a spatial decision support system (SDSS) for forest restoration planning. The stated goal of this chapter was to test the system's efficacy and elicit feedback for further development. The six participants in this test represented a spectrum of stakeholders in restoration of ponderosa pine forests throughout northern Arizona, including representatives from academe, the U.S. Forest Service, a community group, and environmental organizations. Participants developed various restoration scenarios that detailed evaluation criteria, spatial constraints, and priorities for implementing restoration treatments. Each scenario was appraised for overall impact on collectively accepted evaluation criteria and to determine spatial overlaps with other scenarios in preferred locations of treatments. The SDSS not only allowed participants to judge the potential effects of their preferences, played out as spatially explicit scenarios, but also allowed them to identify potential common ground both in terms of spatial overlaps of restoration treatments and shared acceptance of criteria for judging "success." Participants of this initial effort urged the authors to actively pursue engagement with decision-makers to ensure that the newly developed SDSS was used to maximum positive effect.

The next chapter serves as a transition into the Biological portion of this book. Prather et al. incorporate protocols from the SDSS and Forest Ecosystem Restoration Analysis (ForestERA) to create Geographic Information System (GIS) models of the potential effects of forest restoration treatments on 
sensitive wildlife taxa. The information in Chapter \#5 was collected throughout the southern transition area of the Colorado Plateau, along the Mogollon Rim from the Kaibab Plateau to the White Mountains in eastern Arizona. The authors use seven foundation GIS layers, ranging from dominant overstory vegetation, through slope and aspect, to tree density and basal area. From a survey of 40 academic institutions, they provide a list of sensitive taxa that can be incorporated into their model. The authors provide an in-depth example of how their habitat model might be used, taking the tassel-eared squirrel as an example. They demonstrate that their habitat models are additional tools for managers can to potentially apply throughout the Colorado Plateau.

Falzarano et al in Chapter \#6 continue the theme of habitat modeling, using decision tree methods on GAP program data to better classify and analyze land cover data from the northeast corner of Arizona. The authors' proposed approach first develops Geographic Information Systems (GIS) data themes for land cover, vertebrate species distributions, and land stewardship. These GIS layers are seamless across all land management boundaries. The authors then utilize a decision tree to better evaluate habitats of concern and provide conservation of vegetation/vertebrate species. They believe that these newly created GIS products will allow land managers, policy makers, and planners to make better-informed land-use decisions, especially throughout northeastern Arizona.

Vegetation studies are introduced into the Biological section of the book with Chapter \#7, where Nabhan et al. deal with land-use effects on understory plant community composition in southwestern pine forests. Through the comparison of three disparate areas with long cultural histories: the Jemez Mountains (including Bandelier National Monument in New Mexico, Mesa Verde, including Mesa Verde National Park in Colorado, and Wupatki and Sunset Crater National Monuments in Arizona), the authors explore the effects of prehistoric human land use practices and physical location on forest restoration plans. By utilizing the literature and personal interviews, the authors develop a hypothesis that human land-use practices greatly influence plant species composition and that the degree of landuse differs considerably over the Colorado Plateau. They found that post-1850 fire histories among the three areas were much more varied than assumed due to widely varying cultural land use factors. They conclude the chapter by suggesting that restoration plans in pine forests throughout the southwest should be guided by area-specific factors that are developed from cultural, biological, and physical histories of the landscape.

The next four chapters deal with studies that examine vegetation changes in Grand Canyon National Park. Chapter \#8 is the first of three chapters presenting the results of an analysis capitalizing on a rare dataset from 1935 that documented forest conditions in Grand Canyon National Park. In this chapter the authors compare forest conditions during 1935 with contemporary forest conditions documented by three recent studies within higher-elevation mixed conifer forests. They found that the total stand basal area declined since 1935, primarily owing to declines in densities of small and middiameter conifers, primarily white fir, Douglas-fir, and spruce. The authors speculate that these declines were caused by self-thinning and outbreaks of western spruce budworm, and followed substantial increases in densities of small trees between the late 1800s and 1935 that had occurred in response to much reduced fire frequencies. The authors close this chapter by recommending objectives and strategies for restoring mixed conifer forests within Grand Canyon National Park to pre-European settlement conditions.

Chapter \#9 by Coleman et al. extends the analysis introduced in Chapter 8 to the extensive zone within Grand Canyon National Park that transitions between mixed conifer and near pure ponderosa pine forests. The authors begin this chapter by defining transition forests and observing that this vegetation type is not well described, primarily because of its relative scarceness in other parts of the Southwest. Unlike in the mixed conifer forests that are described in Chapter 8, densities of small trees 
have increased since 1935, primarily because of increases in white fir. By contrast, densities of quaking aspen and very large diameter trees (primarily ponderosa pine) have declined. The authors attribute increases in small white fir, and to some extent losses of aspen, directly to reduced fire frequencies, whereas they attribute losses of large pines to increased competition with small trees for moisture. As in Chapter 8 , the authors close by recommending objectives and strategies for restoration of transition forests to pre-European (they utilize the term 'Euroamerican') settlement conditions.

Chapter \#10 concludes the trio of chapters analyzing change in forest conditions between 1935 and the present within Grand Canyon National Park, capitalizing on a rare dataset collected by the National Park Service Bureau of Forestry during the mid-1930s. In this chapter the authors examine changes in near pure ponderosa pine forests, which since 1935 have exhibited substantial increases in small-diameter pines and substantial decreases among the largest classes of trees. As in transition forests (Chapter 9), the authors attribute increased numbers of small trees to substantially reduced fire frequencies since the late $1800 \mathrm{~s}$. They felt that declines in large-diameter trees were due to competition for limited moisture with burgeoning smaller trees. The authors conclude by recommending that Grand Canyon National Park reduce numbers of small trees, maintain numbers of mid- to large-diameter pines, and restore a regime of frequent low-intensity surface fires.

The last chapter focusing on Grand Canyon National Park vegetation, \# 11 by Cole and Cannella, presents an argument for the limitations of plant associations as a frame for mapping and management as compared to the advantages of addressing vegetation distribution and change on the basis of individual species. According to the authors, vegetation communities are ephemeral assemblages of species that often have no archaeological analogs and few prospects of persistence in the face of global climate change. Plant association types are often convenient human constructs that can often obfuscate as much as edify regarding distributions of individual plant species and can lead researchers and managers to not fully appreciate, and thus not preserve or make available, plot data used to define and map association types. Cole and Cannella illustrate the potential benefits of plot data collected for mapping purposes with Utah agave in Grand Canyon National Park. The distribution of Utah agave is not closely linked to any mapped vegetation types, yet varies with land form, elevation, and geology such that plot data can be used to construct predictive models with relevance to anticipating the effects of global climate change. The authors close by urging those involved in vegetation mapping projects to save and make easily accessible their plot data, so that predictive models can be created for individual plant species.

The next four chapters cover management aspects of avian resources on the Colorado Plateau. Chapters \#12 and \#13 by Mark Sogge and his collaborators deal with birds in Grand Canyon National Park and Glen Canyon National Recreation Area. This work is the result of many years of monitoring activities along the Colorado River. The authors provide first in Chapter \#12 a quantitative model of avian community structure along the Colorado River in the two parks, and habitat structures associated with differing avian guild assemblages. Their various models predicted over $75 \%$ of bird occurrence along the Colorado River. Of the major plants along the river corridor, only tamarisk and mesquite vegetation types functioned as good predictors of bird community parameters. One major finding was that as vegetation patch size increased, so did bird species numbers and abundance, thus leading them to support the continued management of large vegetation patches along the river corridor.

In Chapter \#13 Felly and Sogge provide an annotated listing of birds that they observed along the Colorado River between Lees Ferry and Diamond Creek. This chapter was not meant to be an exhaustive list of all birds ever recorded along the river corridor, but this information does add substantially to previously published information and further refines the status, distribution, and seasonality of many bird species. The authors first provide the reader with a brief historical overview of 
the area, then some background on winter birds, migrating birds, and breeding birds. This work concludes with an exhaustive annotated species account of all birds that they observed between 1993 and 1995. This chapter should provide the reader with good insight as to why the Colorado River corridor is important to migrating and breeding birds in Arizona.

In Chapter \#14 Wakeling and Lewis examine the effects of age and gender on mortality and reproduction of Merriam's turkey. They then further explore reproduction in turkey demographics based on population modeling. The authors provide an exquisite example of stochastic population modeling utilizing Monte Carlo simulations, utilizing data from a wide array of turkey studies. They describe turkey population responses to varying levels of fecundity and mortality, and found that the most effective way to increase turkey populations throughout Arizona would be to enhance yearling female reproduction success. On the other hand, gender ratios skewed towards males has the potential to negatively impact turkey populations. The authors suggest in this chapter that, at the current harvest rates, turkey populations in Arizona are not presently being overexploited by hunting.

In a second chapter on wild turkeys, Dubay et al. examine differences in morphological characteristics of transplanted wild turkey populations in Arizona. The general theme in Chapter \#15 is a comparison of Gould's and Merriam's turkey subspecies, in an effort to determine which subspecies presently occurs in the southern Arizona Fort Huachuca flock. The authors present a series of measurements from birds captured at Fort Huachuca, in Sonora Mexico, and from northern Arizona. In all measurements the Gould's Turkeys in southern Arizona and Mexico were more similar than the Merriam's Turkey from northern Arizona. The authors conclude this chapter suggesting that in the Fort Huachuca area, turkeys are more closely related to birds from Sonora, Mexico, and that perhaps this larger subspecies is better adapted to ranges in southern Arizona.

The next two chapters focus on resources and their management just on the southern edge of the Colorado Plateau, at National Park Service areas in the Verde Valley of Arizona. In Chapter \#16 Charles Drost provides a summary of the present status and historic changes of all major vertebrate species found at Montezuma Castle National Monument. This chapter provides a much needed summary of numerous years of a biological inventory that has been undertaken at this National Park Service site. Although the monument was created primarily to protect its remarkable deposits of cultural resources, Drost points out that it also contains diverse vertebrate species.

Chapter \#17 describes inventory research done on western diamond-backed rattlesnakes at Tuzigoot National Monument. Erika Nowak presents the results of her long-term work, focusing on the life history and movement patterns of radio-implanted rattlesnakes at this monument. From information gathered on her numerous snake relocations, she provides the reader with an elegant series of western diamond-backed rattlesnake home-range maps. The findings of this study clearly showed that rattlesnakes had annual activity ranges of less than one kilometer, but because of the monument's small size, more than half the sightings were outside the park boundary. Erika concludes this chapter with a discussion on the proper management of 'nuisance' animals.

Chapter \#18 is a unique application of inventory techniques, documenting invertebrate species assemblages along a vehicle disturbance gradient at Canyonlands National Park in southern Utah. Pech et al. examine the potential impact of off-road vehicles in Salt Creek Canyon, under three usage regimes: no road and use since 1964; closed road since 1998; and, open road where vehicle use still continues. Salt Creek is one of the few perennial riparian environments in this National Park, thus the importance of this study. The authors found a wide variety of beetles, with some limited to specific locations while other species occur at all three locations. They demonstrate, through the use of principal components analysis, that beetle communities vary along the vehicle disturbance gradient. They 
conclude with the recommendation for continued monitoring in order to provide managers with better insights into the potential impacts of off-road vehicles on invertebrate species within Canyonlands.

Chapters \#19 and \#20 deal with managing deer on the Colorado Plateau. Cunningham et al. examine habitat selection by female mule deer in the Mount Trumbull Resource Conservation Area (RCA) in northeastern Arizona. Deer were captured, radio-collared and followed on the ground, with locations recorded while bedding and feeding. Utilizing GIS vegetation data layers, the authors tested if the deer sightings were distributed randomly over three treatment areas. They found that deer preferred to eat in the more open treatment area, but had a preference for bedding in more secure locations associated with denser vegetation patches. Throughout Chapter \#19 the authors stress that oak and New Mexico locust patches should be left when removing vegetation during treatments. In Chapter \#20 Munig and Wakeling examine mule deer harvest estimates from the Kaibab Plateau (Arizona Game Management Unit \#12A). The authors compare results of hunter responses from a voluntary mail-in questionnaire, with the hunter check station information from Jacob Lake. Biases were found in both data sets, but never exceeded $10 \%$. Although the authors do not make any recommendations on which survey is best, they point out that the final decision should be based on data needs, fiscal considerations and public acceptance.

The final two chapters focused on biology deal with management of carnivores on the Colorado Plateau. Chapter \#21 by deVos and McKinney provide readers with background on why mountain lion numbers have increased throughout the western United States over the past several decades. The authors put forth a compelling argument that recent increases in mountain lion numbers are a direct result of decreased exploitive interference from bears and wolves, coupled with changes in vegetative cover that have improved hunting efficiency and caused increases in prey abundance. They attribute prey increases largely to human activities such as ranching and rural animal husbandry, coupled with historical increases in deer numbers in certain locations.

In Chapter 22 Reed and Leslie describe the efficacy of different non-invasive techniques for detecting carnivores and present preliminary results regarding co-occurrence of carnivore species on the North Rim of Grand Canyon National Park. The authors randomly located, without overlap, 20 plots and at each plot established sign transects and placed hair snares and a single remote camera. Sign transects produced the most carnivore detections, cameras were effective for detecting coyotes and rare species, and hair snares were of little efficacy. The authors compared patterns of species detections with expectations based on a null model of random association and found that coyotes and bobcats were detected together less often than expected by chance. Reed and Leslie close by describing future directions for their work, including a greater number of plots on both the North and South Rims of Grand Canyon National Park, de-emphasized use of hair snares, and introduction of track plates.

The cultural resources section of the book opens with a chapter by Smiley and Robbins, focusing on factors that they feel would help provide increased information from looted Rock Shelters over the Colorado Plateau. At present most archeologists avoid working in looted rock shelters because the disturbed environment makes solid archeological inference difficult. Working in previously looted rock shelters from the Comb Ridge of southern Utah, the authors discuss methods for investigating looted sites and provide techniques that will turn site disturbance to a scientific and cultural advantage.

The second cultural chapter of this section (\#24) illustrates another cultural/social challenge on the Colorado Plateau, that being how to preserve cultural resources under extreme fire conditions, especially during the recent 10-year drought that the Colorado Plateau has just experienced. Hough et al. present survey information of 32 field house sites that were recently burned over by a 2002 lightningcaused fire at Wupatki National Monument. From this information, the authors have developed a fuel load assessment on 450 archeological sites from the Flagstaff national park areas and have ranked those 
sites according to their risk potential for fire impacts. Their survey-sampling scheme permitted them to make comparisons across topographic and vegetative divisions of the three Flagstaff national monuments, finding among all site types that cliff dwellings were at disproportionately higher risk for damage from fire due to fuel loading and resource uniqueness and vulnerability. They close this chapter by recommending that on-site hazard fuel reduction should become a routine element of ruins preservation treatment and that archeological sites should be included (not avoided) during large-block mechanical fuels treatment and prescribed fire projects.

Chapter \#25 provides readers with an insight into the extent of cultural resources on the newly acquired lands at Walnut Canyon National Monument. The newly created area of the national monument includes 1420 acres and two new Anasazi 'forts.' The authors employed a standardized survey method that quickly allowed them to collect site attribute information on 210 sites. The age of these new archeological sites ranged from early Archaic to the mid-twentieth century. The sites included 20 sites from the poorly understood Archaic period, many from the Sinagua culture and several important historic structures. The most important historic structure was the Santa Fe Dam, built in the canyon to hold water for steam engines that ran between Winslow and Flagstaff in the early 20th Century.

The final chapter of the cultural section (\#26) documents the efforts and challenges of utilizing cultural resources as part of the park planning efforts at Grand Canyon National Park. Balsam et al. discuss and outline their attempts at using cultural resource information as part of the planning process, rather than unavoidable compliance at the end of the development process. They identify a series of efforts at Grand Canyon National Park that provide the reader with excellent examples of how cultural resources can be included in the National Park management planning process. Considerable time is spent outlining the role that park cultural resources have played in shaping the Glen Canyon Dam Adaptive Management Program. They conclude their chapter pointing out that the politics associated with planning efforts may at first appear intractable, but through providing cultural resource information early in the planning process, integration may be less of an obstacle than most perceive.

The final three chapters of the book cover biophysical facets of the Colorado Plateau. Chapter \#27 provides a transition from the cultural section of this book, examining the impacts of fires on springs in the White Mountain Apache Reservation in eastern Arizona. Long et al. examine the impact of floods on spring-fed wetlands following frequent fires on the western part of the reservation. Following the Rodeo-Chediski wildfire, the authors took site information from 56 spring-fed wetland areas that were affected by the fire. They found that $14 \%$ of the sites had experienced rapid downcutting and provide the readers with mitigation measures that were employed to restore these wetlands. Within a proposed multi-objective decision-making framework, the authors present a preferred spring improvement technique that best meets all concerns of the reservation. The main message of this chapter pertains to a broader series of tribal wetland conservation goals.

Chapter \#28 by Stevens et al. provides a new and novel protocol for the rapid assessment of southwestern stream-riparian ecosystems (RSRA). The authors recognize that stream-riparian ecosystems are among the most productive yet most threatened habitats in the southwest, and that present monitoring methods rely on many subjective techniques. Throughout the chapter the authors build a case for the standardized RSRA, providing managers with a rapid assessment tool that provides information on the functional condition of riparian and associated aquatic habitats. They utilize 4-8 variables in the assessment protocol that range from water quality, through aquatic wildlife, to geomorphology. The protocol outlined in this chapter is designed for small- to medium-sized rivers in the Southwest, but with slight modification would be applicable to temperate region riparian corridors. 
The concluding chapter of the book (Chapter \#29) examines the benefits of calculating large watershed areas with a global positioning system as compared to employing digital elevation models or traditional mapping methods. Poff et al. could find no difference in the final accuracy of the three methods. But they do point out that their new GPS technique is much quicker for managers to use and allows additional time for ground-truthing that assures areas are not omitted from the model. The end result of this technique would result in an accurate assessment of surface runoff and contributions of watersheds to discharge from basin on the Colorado Plateau.

Any scientific work is never a single effort, but a direct result of assistance by many individuals. This book is no exception. We would especially like to thank the following scientific peer reviewers: C. Allen, S. Arundel, T. Arundel, B. Barrett, P. Beier, B. Blackshear, M. Bogan, F. Brandt, M. Brooks, B. Brown, N. Cobb, K. Cole, C. Conway, K. Davis, M. Eaton, W. D. Edge, H. Fairley, D. Falk, P. Ffolliott, L. Floyd-Hanna, B. Gebow, S. Gloss, M. Goode, N. Gotelli, T. Graham, R. Guttierez, H. Hampton, K. Hays-Gilpin, T. Heinlein, J. Hilty, J. Holmes, C. Homer, A. Honoman, B. Howe, R. D. Johnson, T. Jones, P. Krausman, M. Kunzmann, C. Leib, F. Lindzey, K. Logan, J. Mast, M. McGinnis, K. Mock, M. Moore, P. Morgan, S. Nielsen, P. O’Brien, C. Olson, B. Powell, J. Prather, B. Ralston, R. Rasker, S. Rosenstock, C. Schwalbe, H. Shaw, C. Sieg, T. Sisk, M. Sogge, J. Spence, A. Springer, L. Stevens, R. Stoffle, D. Swann, A. Taylor, R. Tausch, T. Teel, T. Theimer, R. Thompson, R. Toupal, J. Unsworth, G. van Riper, D. Wilcox, and H. Zinn all who unselfishly devoted their time and effort to improving each chapter that they reviewed.

Mark K. Sogge, Dennis B. Fenn, Anne Kinsinger, and Douglas Buffington all provided encouragement and/or assistance with finding funding for this publication. Louella Holter helped in many ways with editorial details, and without her attention to detail this book would have never been a reality or finished on time. We would particularly like to thank Kimberly Anne van Riper who contributed the line drawings that are found throughout this book. The dedicated USGS Colorado Plateau Research Station staff (T. Arundel, C. Drost, K. Ecton, J. Hart, J. Holmes, S. Jacobs, M. Johnson, E. Nowak, C. O’Brien, E. Paxton, M. Saul, R. Stevens, M. Sogge, K. Thomas) provided much needed assistance during the 7th Biennial Conference. Finally, we express deep appreciation to our wives (Sandra Guest van Riper and Susan Bischoff) and to our children for their support and understanding during the time that this book was in production.

This work, like other research compilations that are centered on a particular theme, should help to focus attention on research presently being conducted over lands of the Colorado Plateau. In particular, we hope that the state land stewards of Arizona, Utah, Colorado and New Mexico, and managers of National Park, U.S. Forest Service, Fish and Wildlife Service, Bureau of Reclamation, tribal lands and the many new BLM National Monuments will be able to utilize the ideas and concepts presented within each chapter, to launch efforts toward enhanced management and stewardship of their lands in the southwest. Finally, if the material in this volume can act as a stimulus of future research support for management of cultural, natural and physical resources over the Colorado Plateau, it will make the organizational and editorial work of the past two years a worthwhile and productive effort.

\section{Abstracts}

THE COLORADO PLATEAU ECONOMY: SHIFTING PATTERNS AND REGIONAL DISPARITIES

\section{Walter E. Hecox and F. Patrick Holmes}

For the peoples and places of the American West, community economic and population stability tends to be of elemental concern. Many who have a "home on the range" fear that government will take actions in defense of a species or a wildland at the expense of whole communities and their economic 
vitality (Rasker and Roush 1996). These fears have originated from historical conceptions of the community's economic base and periodic exposure to cyclical boom-bust economies in the rural nonmetropolitan West.

Researchers have achieved much in the past two decades to dispel these fears by demonstrating that a new economic base is evolving for these communities. They cite a declining resource-extraction based employment structure and an emerging relationship between public lands and community stability that emphasizes environmental quality and desirable lifestyles as the salient features of the structural transformation of the West's rural economy (Rasker 1993; Rasker and Roush, 1996; Power and Barrett 2001).

The preservation of natural amenity values like scenic beauty, water and air quality, and recreational opportunities has been demonstrated by some to help create new jobs by providing "attractive places to live, work, and do business" (Power 1996). Many have argued that this amenitybased "natural capital" is the foundation of future economic development in the rural West by citing long-term declines in the resource-extracting sectors and long-term growth trends in the service sector. Additional research demonstrating a link between business location decisions and areas with highquality natural amenities has largely disproved the longstanding belief that natural resource extraction is the primary driver of economic prosperity (Johnson and Rasker 1995). In fact, a study by the U.S. Department of Agriculture entitled "Natural Amenities Drive Rural Population Change" found the relationship between the traditional economic base and economic and population growth to be largely nonexistent (McGranahan 1999).

Past studies of regional natural amenity-driven growth have focused mainly on the Greater Yellowstone region of Montana, Idaho, and Wyoming (Rasker 1991; Rasker et al. 1992). The Colorado Plateau's socioeconomic characteristics were first documented in Charting the Colorado Plateau (Hecox and Ack 1996). New data now available for 1970-2000 trace the economic characteristics that define the plateau and identify the dramatic changes facing the region. Additional analysis of the 31 counties incorporating the natural boundaries of the Colorado Plateau focuses here on employment as a measurement of structure and change.

\section{PUBLIC KNOWLEDGE, OPINION, AND SUPPORT OF FOREST RESTORATION: A SURVEY OF RESIDENTS IN NORTHERN ARIZONA \\ David Ostergren and Elizabeth J. Ruther}

After several catastrophic fires since 1990, concern runs high in Arizona and the American West for the health of forest ecosystems. Forest managers, policy makers, researchers, timber industry experts, environmental NGOs and, most importantly, the general public are engaged in debate on future management. All interest groups appear to recognize that forest conditions have changed for the worse and that society needs to reconsider past practices and redirect future actions. However, as with many public land issues, solutions have been proposed and most have proved politically contentious. As management agencies design future strategies, assessing the opinions and perspectives of the public will be crucial to balancing a wide range of expectations for forest resources.

Public opinion is constantly changing and managers need data on social perceptions and expectations to determine desired future conditions. For instance, the perceived role of fire in forest ecosystems has changed dramatically since the 1970s. The public accepts and seems to recognize that prescribed fire is an effective management tool (Gardner et al. 1985; Shelby and Speaker 1990; and others). Land management agencies have used public relations and education programs to change public attitude toward fire, and related research shows the promise of such strategies (Jacobson et al. 2001; Loomis et al. 2001). In northern Arizona, ponderosa pine ecosystems are a focus of concern for city, 
county, state, and federal agencies, the general public, and researchers. Thus, as new information on ponderosa pine ecosystems is disseminated, all interested parties should be aware of how that information changes public opinion.

\section{ATTITUDES TOWARD AND PERCEPTIONS OF MOUNTAIN LIONS: A SURVEY OF NORTHERN ARIZONA RESIDENTS \\ Elizabeth J. Ruther and David M. Ostergren}

In the last 20 years mountain lion (Puma concolor) human conflict has increased dramatically throughout the western United States (Beier 1991; Green 1991; Foreman 1992). Recently, the public and media have been paying more attention to the issue (Reid 2003). Reasons for this trend include an expanding human population, rebounding mountain lion populations from historic lows in the early twentieth century, and rising prey populations surrounding residential developments. Often, the most accessible and productive landscapes that are developed for human use are also prime mountain lion habitat (Halfpenny et al. 1991; Sunquist and Sunquist 2001). These elements join to create interaction and conflict between human and lion.

Because of their large size and high trophic level, mountain lions require large home ranges with an adequate prey base to sustain a viable population (Logan and Sweanor 2001). Human development of mountain lion habitat results in habitat encroachment and fragmentation, both of which directly threaten the mountain lion's existence. Core undeveloped habitat becomes smaller and edges connected to human activity become more numerous. Many times developed areas act as impenetrable boundaries, reducing the cats' ability to find mates or disperse as juveniles (Beier and Barrett 1993; Beier 1995). Eventually, the ratio of intact mountain lion habitat to development reaches a critical threshold where the quality of habitat has diminished to a level in which remaining suitable habitat is virtually nonexistent (Sunquist and Sunquist 2001).

According to the U.S. Census Bureau, the national rate of human population growth from 1990 to 2000 was 13.2 percent. Arizona is the second fastest growing state, expanding at three times the national growth rate, or 39.6 percent (U.S. Census 2000). As the West continues to experience the most extreme population redistribution since the late 1800s (Riebsame 1997), human-lion conflict research has the potential to help mitigate future conflict. Human dimensions of carnivore management studies have not previously been investigated in northern Arizona, and mountain lion-human conflict has increased in recent years in this region. Therefore, results from this report have substantial implications for the future of mountain lion conservation in Arizona, possibly including a reduction in the discrepancies between what the public actually desires and what managers think the pubic desires, which may help reduce both public-agency conflict and human-mountain lion conflict.

Interest in the human dimension of wildlife research is intensifying as the search for the root causes and solutions to predator-human conflict continues (Kellert 1985; Manfredo et al. 1998; Zinn et al. 1998; Riley and Decker 2000; Peine 2001). Looking at the foundation of behaviors and attitudes toward mountain lions may hold the key to reducing conflict.

\section{DEMONSTRATION AND TEST OF A SPATIAL DECISION SUPPORT SYSTEM FOR FOREST RESTORATION PLANNING \\ Haydee M. Hampton, Ethan N. Aumack, John W. Prather, Yaguang Xu, Brett G. Dickson, and Thomas D. Sisk}

The well-documented increase in fuels and decline in health in southwestern ponderosa pine forests since the late nineteenth century have been attributed to livestock grazing, logging, fire suppression, and human development (Cooper 1960; Harrington and Sackett 1990; Swetnam 1990; 
Covington and Moore 1994; Allen et al. 2002). Historical high-frequency, low-intensity fire regimes have been dramatically altered, leading to the increased likelihood of catastrophic fire. Although restoration planning does occur at the project level, treatment implementations have been hindered by the lack of broader-scale analyses in which impacts of alternative plans are compared (Sisk et al., in press). Planning at scales commensurate with key ecosystem processes, such as fire, allows estimation of aggregate effects of management on biodiversity and fire hazard. Given the need for broadscale planning, we developed a spatial decision support system (SDSS) as part of the Forest Ecosystem Restoration Analysis (ForestERA) project (Hampton et al. 2003; Hampton et al., in press) for application to hundreds of thousands to millions of acres. This SDSS may be used to rank and compare alternative forest management plans according to a set of user preferences.

The aim of ForestERA is to provide land managers and the public with the data and tools needed to efficiently use increasing quantities of ecological information, so that forest restoration problems can be addressed at spatial scales broader than individual projects. We have developed a flexible framework for addressing multiple questions regarding management implementation, including forest restoration prescriptions, at the landscape scale. Our SDSS is linked to a collection of integrated models (please note that the original color figures are all available at www.forestera.nau.edu) that predict effects of treatments on forest structure (Xu et al., in press), wildlife distributions (Prather et al., this volume; Prather et al., in press), fire hazard, and other parameters relevant to fire and forest ecology. It can be used more widely than the study region described in this paper; we are currently adapting the underlying models to ecosystems in north-central New Mexico and eastern Arizona.

The SDSS helps stakeholders to define objectives and apply criteria for designing and prioritizing forest treatments and to explore the tradeoffs between alternative management strategies. The first step involves defining the problem to be addressed and objectives to be met by the forest management scenario In the second step stakeholder(s) build a prioritized management action scenario using spatial data that represent values, risks, and other factors. In the third step they select and assess criteria to evaluate the degree to which the scenario achieves its objectives. Estimates of the change in forest structure following various treatments allow us to assess changes in evaluation criteria, such as fire behavior and wildlife habitat characteristics.

\section{MODELING THE EFFECTS OF FOREST RESTORATION TREATMENTS ON SENSITIVE WILDLIFE TAXA: A GIS-BASED APPROACH}

John. W. Prather, Haydee M. Hampton, Yaguang Xu, Brett G. Dickson, Norris L. Dodd, Ethan N. Aumack, and Thomas D. Sisk

Over the past century, human activity has dramatically altered ponderosa pine (Pinus ponderosa) and associated forests in the southwestern United States (Covington and Moore 1994; Covington et al. 1994; Belsky and Blumenthal 1997). Humans have harvested large trees across millions of hectares, grazed their livestock extensively across the land, and actively suppressed wildfire-activities that have changed forest conditions to favor dense stands of small trees and interlocking canopies (Covington and Moore 1994; Mast et al. 1999). These forest conditions are capable of carrying crown fires over very large areas, where, during the previous thousand years at least, frequent ground fires typically burned across large areas, but seldom spread through forest canopies (Covington et al. 1997). Large crown fires, coupled with the expansion of human communities and infrastructure into ponderosa pine ecosystems, have increasingly caused the unprecedented destruction of property, creating the perception that wildfire poses unacceptable levels of risk to humans and the ecosystems that supply them with water, timber, recreation, and a host of other public values (Bosworth 2002). In addition, the competition for resources within dense stands of trees has resulted in reduced tree vigor, and could 
contribute to higher mortality during drought and larger and more frequent insect outbreaks (Zimmerman 2003). High-intensity crown fires and insect outbreaks can significantly degrade wildlife habitat, including critical areas for sensitive, threatened, and endangered species (Chambers and Germaine 2003). For these reasons, many ecologists, conservation biologists, and land managers have called for large-scale management that is designed to reduce the threat of stand-replacing wildfires by restoring degraded ecosystem conditions and ecosystem function, such as frequent ground fire (Covington and Moore 1994; Moore et al. 1999).

\section{USING DECISION TREE MODELING IN GAP ANALYSIS LAND COVER MAPPING: PRELIMINARY RESULTS FOR NORTHEASTERN ARIZONA \\ Sarah Falzarano, Kathryn Thomas, and John Lowry}

The methods used to map land cover (vegetation community and land use) for large regions have developed from extrapolating field-based surveys to interpretation of aerial photography to classification of satellite imagery. These methods typically rely on field data, expert knowledge, and remotely sensed data, and have not incorporated the full potential of important data sources like elevation, geology, and climate. A new method using decision tree modeling (Friedl and Brodley 1997; Brown de Colstoun et al. 2003; Pal and Mather 2003) allows the incorporation of a wide variety of predictor variables to map land cover that include both categorical and continuous inputs.

Creating the land cover map for the second-generation gap analysis in Arizona has provided a great opportunity to use the decision tree approach. The state's topography ranges from low deserts to high mountains, and includes a diversity of vegetation communities. Decision trees allow the incorporation of copious field data and multiple satellite imagery scenes into the model, as well as other mapped data.

\section{LAND-USE HISTORY OF THREE COLORADO PLATEAU LANDSCAPES: IMPLICATIONS FOR RESTORATION GOAL-SETTING}

Gary P. Nabhan, Susan Smith, Marcelle Coder, and Zsuzsi Kovacs

In recent years, stand-replacing wildfires have burned catastrophically throughout the western United States, and society has invested an unprecedented amount of money in preventative forest treatment, creating heated policy debates about thinning, controlled burns, and other restoration activities (Snider et al. 2003). While researchers and resource managers generally agree that restoration of these forests and woodlands to more natural conditions is urgently needed (Covington et al. 1997; Allen et al. 2002; Baker and Shinneman 2004), they differ in the degree to which they attribute the apparently "unnatural" state of our forest ecosystems to fire exclusion and suppression, livestock grazing, climatic fluctuations, bark beetle infestations, or other factors (Allen 1996, 2001; Swetnam et al. 2001; Baker and Shinneman 2004). Activists, loggers, biologists, and recreationists on the Colorado Plateau differ in their opinions regarding the degree to which thinning or controlled burning can truly serve to restore wooded habitats, and what reference conditions or restoration goals are needed to guide such plans (Friederici 2003a). One proposed tool for guiding restoration has been the use of "presettlement conditions" to understand forest stand structure in the ponderosa pine forests before European settlement, and to use restored stand structure as a driver for restoration of ecosystem processes such as frequent, low-intensity fire (Covington and Moore 1994; Friederici 2003b). Policy makers have taken parts of the model and attempted to apply a onesize-fits-all forest thinning policy across the heterogeneous landscapes of the West (Healthy Forests 2002). Such restoration programs are susceptible to rigid prescriptions driven by an inferred ideal of what forests looked like just prior to Anglo settlement (Friederici 2003a). 
There can be no doubt that understanding the shapers of our modern forests and woodlands is an important tool for restoration, and understanding stand structure and past fire frequencies is an important part of that picture. However, there are caveats associated with using pre-settlement conditions as the sole reference point for restoration. As will become clear through our use of case studies, cultural modifications of the landscape began well before European settlement of the West, and these important drivers of change must be taken into account. Second, it may be difficult or impossible to know with certainty what the "presettlement" conditions actually were. Using structure alone, or even in combination with fire frequency, to predict ecosystem function will likely miss such important pieces of the ecosystem as the role and importance of biodiversity, effects of the understory on hydrology, nutrient cycling dynamics, and the role of predators, birds, and other wildlife. Finally, using past conditions as a goal to restore modern forests also underestimates or ignores such new influences as pollution, habitat fragmentation and loss, exotic invasive species, and climate change.

\section{INDICATIONS OF LARGE CHANGES IN MIXED CONIFER FORESTS OF GRAND CANYON NATIONAL PARK}

John L. Vankat, D. Coleman Crocker-Bedford, Don R. Bertolette, Paul Leatherbury, Taylor McKinnon, and Carmen L. Sipe

Mixed conifer forests of the Southwest are poorly understood because of sparse research and diverse stand structure and composition. Nevertheless, it is clear that mixed conifer forests are fundamentally different from the region's other coniferous forests in climate, landscape pattern, and fire regime.

Compared to lower elevation ponderosa pine (Pinus ponderosa) forests, mixed conifer forests have greater precipitation and cooler temperatures, and therefore greater moisture availability. In contrast with higher elevation spruce-fir (Picea-Abies) forests, mixed conifer forests have longer growing seasons. As a result, mixed conifer forests are the most productive coniferous forests of the Southwest (Moir 1993).

APPARENT INCREASES IN MIXED CONIFER CHARACTERISTICS SINCE 1935 IN PONDEROSA PINE-MIXED CONIFER TRANSITION FORESTS OF GRAND CANYON NATIONAL PARK

D. Coleman Crocker-Bedford, John L. Vankat, Don R. Bertolette, Paul Leatherbury, Taylor McKinnon, and Carmen L. Sipe

Coniferous forests of the Colorado Plateau traditionally have been classified as ponderosa pine (Pinus ponderosa), mixed conifer, and spruce-fir (Picea-Abies; Pase and Brown 1994a, 1994b). However, there is a broad band of forest transitional between ponderosa pine and mixed conifer forests on the Kaibab Plateau of northern Arizona (personal observation; Bertolette 2002). We define this ponderosa pine-mixed conifer transition forest as having (a) $\geq 70$ percent overstory trees or basal area composed of ponderosa pine and $(b) \geq 20$ percent understory trees composed of white fir (Abies concolor). Associated tree species include Douglas-fir (Pseudotsuga menziesii) and quaking aspen (Populus tremuloides). In comparison to this transition forest, ponderosa pine forests have greater dominance of the namesake species and mixed conifer forests have greater dominance of white fir, Douglas-fir, blue spruce (Picea pungens), or quaking aspen.

Similar forests have been described, although rarely explicitly labeled as transitional or ecotonal forests. Descriptions have treated these forests as high-elevation ponderosa pine forests (Hurst 1977; Pase and Brown 1994a), low-elevation mixed conifer forests (Wolf and Mast 1998; Mast and Wolf 2004), and fine-grained individual vegetation units (Brown et al. 1979; Warren et al. 1982). From a 
gradient perspective, the transition forest is an exceptionally wide ecotone in the gradient from ponderosa pine to mixed conifer forest. Descriptions of ponderosa pine-mixed conifer transition forests may be uncommon for several reasons. First, most vegetation classifications focus on zonal types and do not include transitions. Second, this transition forest may be uncommon elsewhere because most ponderosa pine forests on the Colorado Plateau are not adjacent to mixed conifer forests. Third, most other areas where these two forests meet are mountainous, where transitions may be narrow and less conspicuous. Fourth, the area of this transition forest may have been small in the past, expanding only when reductions in fire frequencies enabled white fir to invade high-elevation ponderosa pine forests.

Transition areas (ecotones) can be sensitive to environmental change (Neilson 1993; Risser 1995), especially in montane regions (Rusek 1993; Kupfer and Cairns 1996; Hessl and Baker 1997; Mast et al. 1998). However, few investigations of long-term environmental change have occurred in ponderosa pine-mixed conifer transition forests, not only because this vegetation type has lacked recognition, but also because historical data are uncommon for the Southwest in general and for the Colorado Plateau specifically. Moreover, available historical data on uncut forests generally are summary statistics for different study sites across a broad region (e.g., Lang and Stewart 1910).

\section{APPARENT REDUCTIONS IN LARGE-DIAMETER TREES SINCE 1935 IN PONDEROSA PINE FORESTS OF GRAND CANYON NATIONAL PARK \\ D. Coleman Crocker-Bedford, John L. Vankat, Don R. Bertolette, Paul Leatherbury, Taylor McKinnon, and Carmen L. Sipe}

Knowledge of forest structure and composition prior to Euramerican influence is critical for the development of management plans by the National Park Service and other land management agencies responsible for forests. By comparing past with present-day forest conditions, land managers can identify changes that occurred during the period of Euramerican influence and possibly determine causative factors. Knowledge of changes and their causes provides the background necessary for the development of ecologically appropriate approaches to restoring forest ecosystems to their natural range of variability.

Previous studies have indicated that one major change in the ponderosa pine (Pinus ponderosa) forests of the Southwest was an increase in densities of small-diameter conifers, dating to the beginning of Euramerican influence (e.g., Weaver 1951; Harrington and Sackett 1990; Covington and Moore 1994a, 1994b; Dahms and Geils 1997; Swetnam et al. 1999; Allen 2002). Intensive livestock grazing reduced the herbs that had formerly fueled frequent surface fires. As fire frequencies decreased, fireinduced mortality of small-diameter conifers decreased and conifer densities increased.

In contrast, less information is available on whether densities of large-diameter trees (primarily ponderosa pines) changed in areas protected from logging. Early observers did not describe changes in densities of large trees, but any such changes would have involved few individuals and therefore would have been less visually obvious than increases in small trees. Recent observations in Grand Canyon National Park (GCNP) suggest losses of large ponderosa pines.

Changes in densities of large-diameter ponderosa pines are difficult to document quantitatively. Available historical data on uncut forests generally are summary statistics for different study sites across broad regions (e.g., Lang and Stewart 1910; Woolsey 1911). We recently discovered field data-sheets for sample plots from a quantitative vegetation study undertaken in GCNP in 1935. This study was conducted by the National Park Service's Branch of Forestry (BOF) and included all areas of the park (1935 boundaries) with ponderosa pine forests. This data set appears to be the earliest site-intensive, detailed documentation of coniferous forest structure and composition for anywhere in the Southwest. 
We could not relocate and resample the BOF plots in a timely manner, so instead we compared BOF data to data collected recently for forest inventory and monitoring. Our objective was to examine possible changes in forest structure, especially densities of large trees, from 1935 to the present. Vegetation trends since 1935 can aid in estimating pre-Euramerican conditions, knowledge of which is critical for development of fire management goals and practices.

\section{SPECIES-BASED VEGETATION MAPPING: AN EXAMPLE FROM THE GRAND CANYON} Kenneth L. Cole and John A. Cannella

National parks and other land management units have pursued two important goals: (1) developing vegetation association maps for use in Geographic Information Systems (GIS) (http://biology.usgs.gov/npsveg/ index.html) and (2) establishing permanent vegetation plots as a baseline for monitoring change. These two goals are essential for many uses, but the information produced during the identification process on the occurrence of individual species is not always viewed as important enough to retain and distribute. These data, however, especially concerning the relevés sampled during the association mapping and ground-truthing processes, are indispensable for understanding plant distributions at the species level.

A relevé is a ground plot that provides a plant species list from a homogenous area of predetermined size and estimates of the coverage of each species (Mueller-Dombois and Ellenberg 1974). Although originally intended to be a fairly complete listing of species within a plant "community," this method has been abbreviated to record only a handful of dominant trees and shrubs for use in ground-checking maps of plant associations developed from remote sensing. The data from each relevé are far less quantitatively rigorous than those from a more intensively measured vegetation plot, being quickly estimated rather than actually measured. But because less time is required to record each plant, tens of relevés can be completed in the time required for each quantitative vegetation plot or transect. If a study requires measurements across a large and varied landscape, the relevé method can better represent this entire range of spatial variability than will a much smaller number of more detailed plots. For example, if a landscape contains 50 unique combinations of species, 100 relevés will encompass more of this variability than will 20 highly quantitative random plots.

\section{A QUANTITATIVE MODEL OF AVIAN COMMUNITY AND HABITAT RELATIONSHIPS ALONG THE COLORADO RIVER IN THE GRAND CANYON \\ Mark K. Sogge, David Felley, and Mark Wotawa}

Riparian habitats in the western United States, especially those dominated by native vegetation, typically support a disproportionately large number of birds as compared to adjacent non-riparian habitats, in terms of both bird abundance and species richness. The Colorado River corridor in the Grand Canyon is no exception, as it provides important habitat to a large number of wintering, migrant, and breeding birds (Brown et al. 1987; Carothers and Brown 1991; Felley and Sogge, this volume), even though much of the habitat is dominated by introduced tamarisk (Tamarix ramosissima).

Knopf et al. (1988) calculated that riparian habitat covers less than one percent of the land area of the western United States, and much of this is subject to the influence of water management activities (Collier et al. 1996). The rarity and importance of riparian habitats highlights the uniqueness and value of the Colorado River corridor through the Grand Canyon, one of the largest protected riparian areas in the West. The operation of Glen Canyon Dam has affected riparian habitats in the Grand Canyon (Turner and Karpiscak 1980; Anderson and Ruffner 1988; Stevens and Ayers 1994) and the associated bird communities in the past (Brown et al. 1987; Brown 1988b; Carothers and Brown 1991), and will continue to do so in the future. 
Understanding the relationship between riparian vegetation and the habitat of a bird species or community is central to informed river management and conservation of avian resources. This is especially true of the breeding bird community in the Grand Canyon, which includes many riparianobligate breeding species (Brown et al. 1987; Felley and Sogge, this volume). The avifauna of the riparian corridor in the Grand Canyon has received much study, and a number of researchers have looked at bird-habitat relationships in the past (Brown and Johnson 1985, 1987, 1988; Brown et al. 1987; Brown and Trosset 1989). These studies have provided much useful information for some research and management questions, but are generally hard to apply to broader questions regarding bird communities. For example, studies of single species (e.g., Sogge et al. 1997; Brown 1988a) or indicator species (Brown and Johnson 1987; Brown 1988b) have limited application to community-level questions. The use of avian indicator species has been the subject of much debate and criticism in general (Verner 1985; Morrison 1986), and Brown (1988b) found that indicator species were not useful for predicting long-term trends in the breeding bird community along riparian areas in the Grand Canyon. Therefore, bird community studies should include all species within the community of interest (e.g., migrants, breeders, insectivores).

\section{ANNOTATED SPECIES LIST OF BIRDS OF THE COLORADO RIVER CORRIDOR IN THE GRAND CANYON: 1993-1995 \\ David L. Felley and Mark K. Sogge}

The birds listed here were detected during our 1993-1995 studies of the riparian avian community of Colorado River, between Lees Ferry and Diamond Creek. We have included all records of birds that we saw or heard, including non-riparian species such as waterfowl, waders and shorebirds, raptors, and upland-associated songbirds. Other reports and publications also contain more detailed discussions of riparian breeding bird habitat associations and banding results (Sogge et al. 1998; Sogge et al. this volume), survey methods (Felley and Sogge 1997), and avian diet (Yard et al. 2004).

This is not intended to be a cumulative list of all bird species ever detected along the Colorado River corridor, as was provided by Brown et al. (1984) and Brown et al. (1987). Although not "comprehensive" from that standpoint, the information that we present adds substantially to previously published information, and further refines the status, distribution, and seasonality of many species. Furthermore, our data provide a "snapshot in time" of the diversity, distribution, and abundance of birds in the canyon during the period of our survey; such information can facilitate valuable comparisons with future avian research and monitoring data.

\section{IMPLICATIONS OF MERRIAM'S TURKEY AGE, GENDER, CAUSE-SPECIFIC MORTALITY, AND REPRODUCTION ON POPULATION DEMOGRAPHICS BASED ON POPULATION MODELING}

\section{Brian F. Wakeling and Charles H. Lewis}

Many demographic parameters influence turkey populations (Wakeling 1991; Roberts et al. 1995; Roberts and Porter 1996); these include age, gender, cause-specific mortality, and reproduction. In Arizona, turkey population size fluctuates substantially among years, as do the proportion of female turkeys that nest, the proportion of nests that successfully hatch, and age-specific survival rates for females (Wakeling 1991; Wakeling and Shaw 1994; Mollohan et al. 1995; Rumble et al. 2003). The objective of turkey management is generally to manage harvest or habitat to influence population size, yet imprecise knowledge of population demographics may limit the ability of management agencies to achieve the desired outcome. Population models can help biologists determine the relative importance of common demographic parameters that affect annual population change. Once identified, managers can 
concentrate on the determination of intrinsic or extrinsic factors responsible for the annual variation of the most meaningful demographic parameters. Our objective in this study was to improve our knowledge of population demographics by using deterministic and stochastic population modeling, based on published estimates of demographic parameters.

\section{MORPHOLOGIC CHARACTERISTICS OF A TRANSPLANTED POPULATION OF GOULD'S TURKEYS WITH COMPARISONS TO MERRIAM'S TURKEYS \\ Shelli Dubay, Brian Wakeling, and Tim Rogers}

Gould's turkeys are believed to be the largest subspecies of turkey in North America (Schemnitz and Zeedyk 1992), but limited comparative data exist. Genetic data indicate that Gould's turkeys are the most genetically divergent subspecies of turkey in North America (Mock et al. 2001a). As a result, Gould's turkeys may be different genetically and morphologically, and potentially ecologically distinct as well. Our objective was to compare morphological traits from a reestablished population of Gould's turkeys in Arizona to Gould's turkeys from Mexico and to Merriam's turkeys in northern Arizona. Specifically, (1) we measured mean weight for Gould's turkeys in the Huachuca Mountains, Arizona and in Sonora, Mexico and for Merriam's turkeys (M. g. merriami) in northern Arizona; (2) we measured beard length in adult male Gould's turkeys in Arizona and in Sonora, Mexico; (3) we measured tarsometatarsus length for Gould's turkeys and Merriam's turkeys in Arizona; and (4) we compared morphological characteristics from Gould's turkeys captured in the Huachuca Mountains to published records for other turkey subspecies.

\section{VERTEBRATES OF MONTEZUMA CASTLE NATIONAL MONUMENT: PRESENT STATUS} AND HISTORICAL CHANGES

\section{Charles A. Drost}

An integrated, broad-based inventory of the flora and fauna of Montezuma Castle National Monument in central Arizona was undertaken between 1991 and 1994 to provide information on current status, trends, and potential management concerns of the natural resources of the monument. Components of the inventory included terrestrial vegetation (Rowlands 1999), aquatic invertebrates (Blinn et al. 1996), terrestrial invertebrates (Price and Fondriest 1998), fish (Montgomery et al. 1995), amphibians and reptiles (Drost and Nowak 1998), mammals (Drost and Ellison 1999), and birds (Sogge and Johnson 1998), as well as a series of historic photos documenting changes in the area (Richmond 1995). The work was a collaborative effort by researchers from Northern Arizona University and the Colorado Plateau Research Station in Flagstaff, Arizona, and was supported by funding from the National Park Service. Final project reports that provide detailed results are available from the USGS Colorado Plateau Research Station.

Montezuma Castle National Monument is a unit of the National Park Service in central Arizona, established to protect Sinagua culture cliff dwellings, notably the five-story, 20-room structure known as Montezuma Castle, perched imposingly on a limestone cliff face overlooking lower Beaver Creek. The monument consists of two separate sites; Montezuma Castle (the "Castle unit") and Montezuma Well, $8 \mathrm{~km}$ apart in the Verde River valley between Flagstaff and Phoenix. The Montezuma Well section protects additional Sinagua and Hohokam sites, as well as a large, spring-fed limestone sink (from which the site receives its name) that has no known parallel anywhere in the world in its depth, its highly carbonated waters, and its uniquely adapted endemic invertebrate community. Montezuma Castle is a relatively small national monument: the Castle section encompasses about $2.5 \mathrm{sq} \mathrm{km}$, and the Well section is just over $1 \mathrm{sq} \mathrm{km}$. The area is mid-elevation desert, ranging from 955 to $1090 \mathrm{~m}$; it supports scattered juniper at its higher elevations and mesquite, acacia, and creosotebush at its lower elevations. 
There is a diverse cottonwood riparian association along Beaver Creek in its course through the monument.

As with many "cultural parks," Montezuma Castle National Monument has had relatively little research on plant and animal communities and other natural resources. However, the monument protects valuable samples of regional biological communities. In many respects, the same features that drew early humans to the area also provide for rich biological communities, like the extensive riparian habitat at Montezuma Castle, and these biological communities gain added importance by virtue of their longterm protection as monuments and parks. The poor state of knowledge of the biological resources at the monument was one of the driving forces behind this inventory project.

\section{MOVEMENT PATTERNS AND NATURAL HISTORY OF WESTERN DIAMOND-BACKED RATTLESNAKES AT TUZIGOOT NATIONAL MONUMENT, ARIZONA Erika M. Nowak}

The 1916 National Park Service Organic Act states, in part, that the purpose of national parks is to "conserve the scenery and natural and historic objects and the wildlife therein and to provide for the enjoyment of the same in such manner and by such means as will leave them unimpaired for the enjoyment of future generations" (National Park Service 1980). Park wildlife that is potentially hazardous to visitors and staff, such as rattlesnakes, should be managed only after "scientific research and planning that ... will protect the resources within parks in an effective and ecologically sound manner" (National Park Service 1991).

Tuzigoot National Monument, which was established solely to protect hilltop Sinagua culture sites, is located on approximately 43 acres in the Verde Valley of north-central Arizona. At least two species of rattlesnakes are found there: western diamond-backed rattlesnakes (Crotalus atrox) and black-tailed rattlesnakes (C. molossus). Although no rattlesnake studies had been completed at Tuzigoot prior to this work, C. atrox have been studied in detail in the eastern portion of the Verde Valley at Montezuma Castle National Monument by Nowak and van Riper (1999), and in central and southern Arizona by Taylor et al. (2004, 2005), Repp (1998), Hare and McNally (1997), Beaupre (1995), Beck (1995), and Schuett and Repp (unpublished data).

Several factors suggest that the rattlesnakes at Tuzigoot may behave differently or use available habitat differently when compared to these previous studies. Tuzigoot is a very small monument that does not contain a high diversity of habitats or physical features. There are no riparian habitats or extensive limestone cliff outcrops within the monument, although these features do exist within $0.5 \mathrm{~km}$ of its boundary. Just east of Tuzigoot lies the large, spring-fed Tavasci Marsh; no field research on Southwestern rattlesnakes has yet occurred in proximity to marsh systems. The original marsh, which was re-created by the Arizona Game and Fish Department, is currently expanding, with some help from beavers (Castor canadensis). The marsh is within the normal range of rattlesnakes using the monument, and it may influence their habitat use patterns. The small size of the monument may cause migratory wildlife such as rattlesnakes to be particularly vulnerable to encroaching urban development. For example, construction of a residential golf course community by the Phelps Dodge Corporation is ongoing on the west and south boundaries of the monument. Adjacent development may have immediate or long-term effects on rattlesnakes (e.g. Nowak et al. 2002; Goode et al. 2003), but without baseline data on the habitat use and resource needs of rattlesnakes at Tuzigoot, any impacts may go undetected.

To help develop scientifically based management strategies for Tuzigoot rattlesnakes, with the help of Manuel Santana-Bendix, I undertook a 3-year telemetry study of the natural history of resident Crotalus atrox. 


\section{BEETLES OF SALT CREEK CANYON, CANYONLANDS NATIONAL PARK, UTAH}

\section{Louis L. Pech, Timothy B. Graham, Holly Demark, and Jennifer Mathis}

In arid and semi-arid ecosystems, riparian zones possess greater biodiversity than surrounding uplands, with as much as 90 percent of species either found in or using riparian areas (Carothers 1977; Ohmart and Anderson 1982). Due to the availability of water, riparian zones are also the most productive regions in arid and semi-arid ecosystems (Lowe 1964; Lowe 1989). Increased structural complexity and increased productivity provide a greater diversity of niches to exploit (Crawford 1981; Crawford 1986; Whitford 1986).

Riparian zones in arid and semi-arid environments that support diverse biological communities are also subject to many human activities such as livestock grazing, water diversion, and channel alteration, as well as hiking, bicycling, and the use of off-road vehicles (Kondolf and Curry 1984; Mitchell and Woodward 1993; Green and Kauffman 1995; Briggs 1996). Despite the importance of these riparian zones, little is known about the effects of off-road vehicles (ORVs). It is possible that ORV effects are similar to trampling by livestock, which causes changes in the three-dimensional structure of habitats by crushing plants and compacting soil; community structure then changes over time due to the increased relative abundance of plants that are resistant or insensitive to disturbance (Kauffman et al. 1983; Kauffman and Krueger 1984; Fleischner 1994; Niwranski et al. 2002). Insect communities also change in response to these changes in habitat structure and the abundance and diversity of host plants (Capinera and Sechrist 1982; Jepson-Innes and Bock 1989; Quinn and Walgenbach 1990; Niwranski et al. 2002). Cessation of ORV use would presumably result in changes in the three-dimensional architecture and community structure of riparian zones; however, how a desert riparian insect community would change upon removal of ORVs is currently unknown.

Salt Creek Canyon in Canyonlands National Park (CANY) has for many years been subject to ORV use. Salt Creek flows from the Abajo Mountains into the Colorado River in the Needles District of CANY. It is especially significant because, other than the Colorado and Green Rivers, it is the largest perennial or semiperennial stream in CANY and one of the biologically most productive areas in the park. Because of its ecological significance to CANY, much of Salt Creek Canyon was closed to vehicles in 1998. As a result, the canyon is now divided into three regions: No Road (NR) where vehicle use ended in about 1964, Closed Road (CL) where vehicle use ended in 1998, and Road Open (RO) where limited vehicle use continues. These three regions provide an opportunity to examine the effects of ORVs on the community structure of a desert riparian ecosystem, and to evaluate how the community changes when ORV use ceases.

\section{LANDSCAPE HABITAT SELECTION BY FEMALE MULE DEER IN A PARTIALLY RESTORED PONDEROSA PINE FOREST IN NORTHWEST ARIZONA}

\section{Stan C. Cunningham, Stephen S. Germaine, Heather L. Germaine, and Susan R. Boe}

Southwestern U.S. ponderosa pine (Pinus ponderosa) forest communities evolved with episodic ground fires (> 5,000 ha) approximately every 2-10 years pre 1880 (Swetnam and Betancourt 1990). However, since the mid to late 1800s, aggressive wildfire suppression, livestock grazing, and even-aged timber management have tended to homogenize ponderosa pine forests (Allen et al. 2002). Current condition ponderosa pine forests are densely stocked (up to $>500$ trees/ha), and understory grasses, forbs, and shrubs have declined (Covington and Moore 1994; Bogan et al. 1998). Large trees have decreased in number due to logging (Allen et al. 2002), meadow size has decreased due to small tree invasion (Swetnam et al. 1999), and floral and faunal biodiversity levels have decreased (Allen 1998). 
These conditions have increased the risk, size, and number of stand-replacing fires (Swetnam and Betancourt 1998).

Although dense stands of suppressed ponderosa pine trees have always been present, they are more prevalent today (Cooper 1960), and a broad scientific, social, and political consensus has recently emerged that restoration of ecological sustainability in southwestern pine forests is necessary and urgent (Covington and Moore 1994; Covington et al. 1997; Allen et al. 2002). Restoration treatments to reduce trees to historic densities ( \pm 80 trees/ha; Covington et al. 1997) are now proposed for $>81,000$ ha annually in Arizona and New Mexico (Anonymous 2001).

Reducing tree density in landscape-scale areas ( $>50$ ha) should influence mule deer (Odocoileus hemionus) populations. Reductions in herbaceous and shrub productivity in dense forests, and lower diversity and senescence of existing browse have contributed to mule deer declines in recent decades (Julander and Low 1976; Carlson et al. 1993; Carpenter 1998). Mule deer population fitness is believed to be superior in early successional stage habitat rather than in later stages, when most nutrients are tied up in woody material (Wallmo and Schoen 1981).

Post-fire benefits to mule deer have been documented in ponderosa pine (Hungerford 1970), pinyon pine (P. edulis)-juniper (Juniperus osteosperma; McCulloch 1969; Stager and Klebenow 1987), and pine-oak (Quercus spp.) habitats (Kie 1984). After a burn, forbs and green grass increase (Thill et al. 1990; Kucera and Mayer 1999), and rapidly growing young or resprouting browse is usually more nutritious than older browse. Thus restoration treatments that open tree canopies and use controlled burning should increase forage and benefit mule deer. However, removal of thermal and hiding cover could be negative; mule deer distribution and density in presettlement (pre-1870) ponderosa pine forests remain unknown (Wagner et al. 2000; Block et al. 2001).

\section{AN EVALUATION OF MULE DEER HARVEST ESTIMATES ON THE NORTH KAIBAB, ARIZONA}

Amber A. Munig and Brian Wakeling

Harvest estimates are important because they provide data useful for managing hunted species. The Arizona Game and Fish Department (AGFD) manages Unit 12A for buck hunting opportunities that emphasize harvest of older age class animals, reduced hunter densities, and higher hunt success. Data collected from a mandatory hunter check station, a mail questionnaire, post-hunt population surveys, and forage monitoring are used when establishing hunts and permit levels. Knowledge of the bias and precision of harvest estimates is important because managers can then infer the degree of confidence from which they base decisions. The AGFD uses two techniques to estimate harvest: a mandatory check station for successful hunters in Unit 12A and a voluntary mail questionnaire that is used statewide, including Unit 12A. AGFD has used the mail questionnaire for harvest estimation for more than 40 years, but recent concerns regarding its accuracy and precision have arisen with the public because the two estimates differ. An evaluation of the mail questionnaire program has not been completed in about 10 years.

\section{RECENT TRENDS IN NORTH AMERICAN MOUNTAIN LION POPULATIONS: A HYPOTHESIS James C. deVos, Jr., and Ted McKinney \\ Mountain lion (Puma concolor) abundance has increased in recent decades throughout the western United States and Canada (Logan and Sweanor 2001; Riley and Malecki 2001). The mountain lion has also established or is reestablishing in areas of the Great Plains and eastern and midwestern North America (Riley and Malecki 2001; Tischendorf 2003). Resource managers consider the mountain lion to have been extirpated from these regions more than a century ago, but documented encounters}


between mountain lions and humans, including human deaths and injuries, have been increasing throughout western North America since the 1970s (Beier 1991; Danz 1999; Mattson et al. 2003).

Hopkins (2003) suggested the general notion that mountain lion abundance is increasing throughout the West over the last 2-3 decades, but the report lacks quantitative support. Recently, researchers in the northwestern United States have suggested that mountain lions might be declining in that region, despite an increase in reported human-mountain lion conflicts (Lambert et al. 2003). However, the consensus seems to be that mountain lion abundance in the West is increasing, a conclusion based largely on upward trends in annual hunter harvest (Logan and Sweanor 2001; Riley and Malecki 2001). Although Logan et al. (2003) suggested that recent mountain lion increases may be due to legal protection and increasing prey abundance during the 1970s to mid-1990s, the causal mechanisms of the upward trends in mountain lion abundance and distribution are poorly understood.

Sport hunting is a major cause of mountain lion deaths in most western states, and many wildlife management agencies use regulated sustained-yield harvest to manage mountain lion populations. Estimates of mountain lion population size and population dynamics relative to management prescriptions are generally derived from harvest estimates. Most states that allow legal hunting of mountain lions prohibit killing females with kittens, but this measure may be ineffective (Logan and Sweanor 2001). Mountain lion abundance has increased in many but not all states and provinces, whether mountain lion sport hunting is regulated, unregulated except for required possession of a hunting license as in Texas (Russ 1989), or prohibited as in California (Mansfield and Weaver 1989, Table 1).

We reviewed historic and recent trends of predator and ungulate population abundance and distribution, habitat loss and fragmentation, predator control, changes in vegetative cover, and the ecology of large carnivores in North America, mountain lions, grizzly bears (Ursus arctos), and gray wolves (Canis lupus), in an effort to understand why the abundance and the distribution of mountain lions have increased in some areas of the western United States and Canada.

\section{PATTERNS OF CARNIVORE CO-OCCURRENCE ON THE NORTH RIM, GRAND CANYON NATIONAL PARK \\ Sarah E. Reed and Elaine F. Leslie}

Extinctions of mammal species in U.S. national parks have led to increased concern about the fate of the remaining carnivores (Newmark 1995; Parks and Harcourt 2002). Predators affect trophic processes through predation (Estes and Palmisano 1974) and scavenger subsidies (Wilmers et al. 2003), and changes in species composition can have important effects on community structure and stability (Mittelbach et al. 1995; Crooks and Soulé 1999). Wide-ranging, low-density carnivores are particularly at risk for population declines due to edge effects and external threats posed by humans (Woodroffe and Ginsberg 1998).

Conserving multiple species across the landscape requires an understanding of spatial relationships among species as well as the habitat relationships of each species. Laboratory and field experiments have demonstrated local impacts of predation and competition on species distributions (e.g., Huffaker 1958; Connell 1961) and research on radio-collared animals has shown that mammalian carnivores avoid each other in space (Fedriani et al. 1999; Neale and Sacks 2001). However, few studies consider interaction processes in the design of noninvasive surveys and monitoring (e.g., Fedriani et al. 2000). Distribution models are typically based on site and landscape variables related to habitat quality (e.g., Virgos et al. 2002) and do not incorporate data on the distributions of co-occurring species. These sampling and modeling approaches implicitly assume that species distributions are not correlated in space. 
Null model analyses of community structure and species co-occurrence are popular tools for investigating spatial relationships in species presence/absence data. Null model analysis has been proposed as a method for quantifying non-random co-occurrence patterns arising from competitive exclusion in island ecosystems (Diamond 1975; Connor and Simberloff 1979). The null model approach has been controversial, but many statistical concerns associated with early analyses have been addressed (Gotelli 2000). A recent meta-analysis of 96 data sets encompassing a variety of taxa and ecosystems showed non-random patterns of species co-occurrence according to several well-tested indices of community structure (Gotelli and McCabe 2002).

In this chapter, we describe a pilot study pairing multiple carnivore species surveys with analyses of community structure and co-occurrence. We conducted our research in the relatively homogeneous ponderosa pine forest of the North Rim of Grand Canyon National Park (GCNP), where we assumed that any co-occurrence patterns we observed would be primarily attributable to interspecific effects rather than habitat variation. Our objectives were to evaluate three non-invasive survey methods for the detection of mammalian carnivores and to assess analysis methods for testing patterns of community structure and species co-occurrence. We identify the combination of methods that were most effective for detecting the presence of all of our target species.

\section{HELP FOR THE LOOTED ROCKSHELTERS OF THE COLORADO PLATEAU IN A NEW CENTURY OF ARCHAEOLOGY: NEW BASKETMAKER II RESEARCH ON THE GREAT COMB RIDGE}

\section{Francis E. Smiley and Michael R. Robins}

The archaeology of southeastern Utah looms large in the history of archaeological investigations in the American Southwest because some of the earliest archaeological investigations on the Colorado Plateau took place in southeastern Utah and other areas of the Four Corners region before the turn of the twentieth century. The work focused on rockshelters, in many ways the most visible of archaeological sites. The shelters contained remarkably well preserved perishables such as baskets, sandals, atlatls, and corn. The excavators approached their work with insight, avarice, and unlimited energy, mowing down rockshelters like Dakota wheat.

Many excavators ripped and tore and sent the recovered materials into the void of the antiquities market. But responsible archaeologists, most notably Kidder and Guernsey (1919; Guernsey and Kidder 1921), contributed much to our understanding of the prehistory of the Southwest, and in national and university museums we have remarkable collections of virtually every aspect of the lives of the Basketmakers: the early Neolithic Anasazi culture, the material remains of which typically dominate rock-shelter assemblages in the Four Corners area. We use the term "Neolithic" in the sense that Smiley (1997a) applied it to the beginnings of farming in the American Southwest. Just as the term has been in general use for many decades (e.g., Childe 1953) with reference to early farming societies in the Middle East, Africa, Europe, and the Far East, so is the term applicable to the societies of the Southwest.

A century later, the question remained: What, if anything, may be left of the remains of the Basketmakers? We present the results of ongoing archaeological research on the Colorado Plateau's earliest farmers, the Basketmaker II groups, who now appear to date as early as $4000 \mathrm{BP}$. We use the term "Basketmakers" to refer to the Basketmaker II peoples of the northern Southwest, not including later, ceramic-period Basketmaker III groups in the same regions.

\section{FIRE EFFECTS RESEARCH AND PRESERVATION PLANNING AT WUAPTKI AND WALNUT CANYON NATIONAL MONUMENTS, NORTHEAST ARIZONA}

Ian Hough, Jeri DeYoung, and David Barr 
Two recent projects at Wupatki and Walnut Canyon National Monuments in northeast Arizona have focused on the effects of wildfire on archaeological sites. The Wupatki project was designed to study the effects of historically absent grass fires on archaeological sites and to identify potential longterm site preservation issues. The Walnut Canyon project evaluated fuel loads and fire risk at 458 archaeological sites. The primary objectives were to evaluate differences in fuel loading and fire risk potential between vegetation classes and site types, and to identify preservation issues associated with the threat of damage from wildland fires in the monument.

\section{ARCHAEOLOGICAL SURVEY OF NEW LAND ACQUIRED BY WALNUT CANYON NATIONAL MONUMENT, NORTHERN ARIZONA \\ Kimberly Spurr and L. Theodore Neff}

The Navajo Nation Archaeology Department (NNAD) and the National Park Service (NPS) conducted an archaeological survey in Walnut Canyon National Monument between October 2001 and May 2002, except during a 2-month period when snow prevented fieldwork (Neff and Spurr 2005). The primary purpose of the survey was to document all cultural resources in land acquired by the monument from the Coconino National Forest in 1996, as well as land adjacent to the entrance road corridor, to allow NPS administrators to monitor impacts and implement preservation plans for the resources (Neff 2001). The survey was undertaken to comply with Section 110 (a)(1) of the National Historic Preservation Act (Public Law 89-665; 80 Stat. 915; 16 U.S.C. 470, as amended), which directs federal agencies to "undertake a program to identify historic properties under its jurisdiction or control." A secondary goal was to compare site types and land use/settlement patterns in the new land with those documented by a survey of the monument lands in 1985 (Baldwin and Bremer 1986).

Walnut Canyon National Monument is about $16 \mathrm{~km}$ (10 miles) east of Flagstaff, lying south of Interstate 40 and north of Anderson Mesa. The portion of Walnut Canyon encompassed by the monument contains a wealth of archaeological sites, most notably clusters of masonry rooms tucked beneath limestone ledges on the canyon slope. The earliest documentation of these ruins was by James Stevenson, who led an expedition from the Smithsonian Institution through the area in 1883 (Stein 1986:49). The next decade saw numerous visits by scientific researchers, as well as a growing interest in the ruins among local residents. Construction of a wagon road from Flagstaff to the north rim of Walnut Canyon in 1884 facilitated scientific and recreational expeditions and offered more direct access to the well-preserved ruins on the north slopes of the canyon. Growing visitation and extensive artifact collecting, including the use of hand tools and dynamite to remove masonry walls to access the rooms, took a heavy toll on the ruins. Besides damage to the ruins and loss of archaeological materials, the natural beauty of the area was also marred by trash discarded by visitors (Stein 1986:54). By the mid1890s several local residents and businessmen realized that the ruins in Walnut Canyon were unusual and, if preserved, could be promoted as a tourist and scientific attraction. They began to lobby for establishment of a preserve to protect the canyon and its ruins.

\section{USING CULTURAL RESOURCES AS PART OF THE PLAN: GRAND CANYON MANAGEMENT AND IMPLICATIONS FOR RESOURCE PRESERVATION}

Janet R. Balsom, J. Grace Ellis, Amy Horn, and Lisa M. Leap

The Grand Canyon is a natural wonder, known throughout the world for its scenic beauty and rich geologic history. It is a crown jewel in the National Park system, one of the Seven Wonders of the World, and a World Heritage Site. Yet behind the scenery lies 10,000 years of human history. This history reflects the complex and varied interaction of people with this rugged landscape . An estimated 50,000 archaeological sites are thought to exist in Grand Canyon National Park (GCNP), including 
Archaic lithic scatters, split-twig figurine caves, Puebloan settlements, and historic period Native American structures. The 870 historic buildings and structures include National Historic Landmarks designed by Mary Elizabeth Jane Colter, rustic miners' cabins, and historic National Park Service (NPS) structures and trails. Historic designed landscapes are located in most of the developed areas of the North and South Rims, and Traditional Culture Properties and Native American sacred sites are present throughout the park.

The grandeur and beauty of the Grand Canyon attracts nearly 5 million visitors per year. The National Park Service endeavors to preserve cultural resources while accommodating visitor enjoyment. Therefore, it is essential that cultural resource concerns and information be a part of the park planning process. Current planning efforts at Grand Canyon National Park are increasing the integration of cultural resource information.

In 1995, Grand Canyon National Park completed and began implementing its General Management Plan (GMP; U.S. Dept. of Interior 1995), which outlines plans for visitor use and infrastructure development in the park. The Fee Demonstration Program allows the park to keep a share of its revenues, providing funding for widespread infrastructure repair and development . Repairs and improvements to Grand Canyon National Park's infrastructure take place within historic districts, in National Historic Landmark buildings, in areas with cultural resources, and in Native American traditional use areas. The GMP provides a broad outline for these activities, with specific resource information helping to guide specific projects. For example, the design of the new Desert View entrance station on the eastern end of the South Rim has been thematically tied to the design of the historic buildings in the area. The Colter-designed Desert View Watchtower, the centerpiece of the area, is a National Historic Landmark building (NPS 2005). In its distinctive yet compatible design, the entrance station will be faced with rubble masonry similar to that found on the Watchtower, but the building's form will be twenty-first century.

Many tools provide an opportunity to use cultural resources as part of the park planning process. Whether it is tribal resource identification, traditional archival materials, archaeological site inventories, or user-discretionary time models, all play a role in helping park management make better decisions for the resources of the park.

\section{FIRE AND SPRINGS: REESTABLISHING THE BALANCE ON THE WHITE MOUNTAIN APACHE RESERVATION \\ Jonathan Long, Mae Burnette, and Candy Lupe}

The Rodeo-Chediski fire of 2002 was the largest wildfire in the history of the Southwest. The fire severely burned large swaths across the northwest quarter of the White Mountain Apache Reservation in Arizona. This part of the Mogollon Rim contains an especially high density of springs (Stevens and Nabhan 2002). Wildfire research and rehabilitation efforts have not emphasized spring-fed ecosystems, despite their ecological and cultural importance. After the fire, we initiated a project to assess and prescribe treatments to rehabilitate wetlands where post-fire flooding threatened important values.

\section{A PROTOCOL FOR RAPID ASSESSMENT OF SOUTHWESTERN STREAM-RIPARIAN ECOSYSTEMS}

Lawrence E. Stevens, Peter B. Stacey, Allison L. Jones, Don Duff, Chad Gourley, and James C. Catlin

Riparian habitats, including stream margins, springs, wet meadows, and marshes, are areas "inundated or saturated by surface or ground water at a frequency and duration sufficient to support, and which, under normal circumstances do support, a prevalence of vegetation typically adapted for life in 
saturated soil conditions" (U.S. Department of the Interior 1992). Riparian habitats are inseparably linked to the associated stream's hydrogeologic and geomorphic processes, antecedent and contemporary flows, sedimentology, and local and regional land management practices, as well as to the condition of adjacent upland ecosystems (Hupp 1988; Gregory et al. 1991; Malanson 1993; Mitsch and Gosselink 1993; Stromberg 1993b; Auble et al. 1994; Leopold 1994; McCammon et al. 1998; Chambers and Miller 2004). Stream-riparian ecosystems are among the most biologically diverse, productive, and threatened habitats in the American Southwest (Johnson and Jones 1977; Johnson et al. 1985; Knopf et al. 1988; Ohmart et al. 1988; Johnson 1991; Stromberg 1993a; Minckley and Brown 1994).

Southwestern riparian habitats support diverse and unique assemblages of distinctive species not found elsewhere, as well as many facultative species from the surrounding uplands (Johnson 1991; Minckley and Brown 1994; Stacey 1995; Naiman and Decamps 1997; Naiman et al. 2002; Sabo et al. 2005).

Stevens and Ayers (2002) reported that natural stream-riparian habitats make up less than 1 percent of the northern Arizona landscape, yet directly support more than 35 percent of the higher plant and bird species, as well as many facultative upland plant and animal species. Desert riparian habitats commonly have $\leq 2$ orders of magnitude greater productivity than the surrounding uplands (Perla and Stevens, in press). Southwestern stream-riparian ecosystems also serve as invasion corridors for non-native species (Stevens and Ayers 2002), elevating the need for appropriate management policy and action (Simberloff et al. 2005).

\section{DETERMINING WATERSHED BOUNDARIES AND AREA USING GPS, DEMS, AND TRADITIONAL METHODS: A COMPARISON}

\section{Boris Poff, Duncan Leao, Aregai Tecle, and Daniel G. Neary}

Defining a watershed's boundary is critical for understanding the movement of water across the landscape. In the past, hydrologists defined watersheds using topographic map features such as contour lines, stream networks, and traditional surveys. However, the more advanced current techniques for defining watershed boundaries use Geographic Information Systems (GIS) in conjunction with Digital Elevation Models (DEMs; Maidment 1999). GIS is an important tool in resource management today. Because of its precision and accuracy, we expect the Global Positioning System (GPS) to be more appropriate for delineating watershed boundaries and calculating area than traditional forestry field methods of using a compass and chain. We also expect GPS surveyed boundaries to be more precise than those determined using DEMs, because DEMs rely on $10 \mathrm{~m}$ topographic intervals, which can lead to faulty results, especially in areas with small elevation differences.

After "selective availability" was removed from GPS technology in May of 2000, potential point location error without differential correction dropped from 100 to $3 \mathrm{~m}$. According to Oderwald and Boucher (2003), this indicates that a single point observation on average is within approximately $3 \mathrm{~m}$ of its true location. In contrast, on a 1:24,000 topographic map, a $0.5 \mathrm{~mm}$ pencil line is $12 \mathrm{~m}$ wide (Oderwald and Boucher 2003).

In our study, we chose not to apply post-processing differential correction to our data for three reasons. First, users may not have access to base stations to differentially correct their data or may not have the expertise to do so. Second, low-end, consumer-grade GPS units may not offer the option of differential correction. Third, we assume that for areas greater than 20 hectares (ha) in size cumulative error is insignificant due to the randomness distribution of the horizontal error distance (which averages between 3 and $4 \mathrm{~m}$ for each point; Wilson 2000). DEMs are digital representations of surface elevations laid out over the landscape. A DEM is produced from digitized map contours, spot elevations, and hydrography overlays or from manual scanning of aerial photographs (Elassal and Caruso 1983; Maidment and Djokic 2000). DEMs are valuable because they provide managers with the same 
information as contour maps, but in a digital format suitable for processing by computer-based systems rather than in an analog format (Cho and Lee 2001).

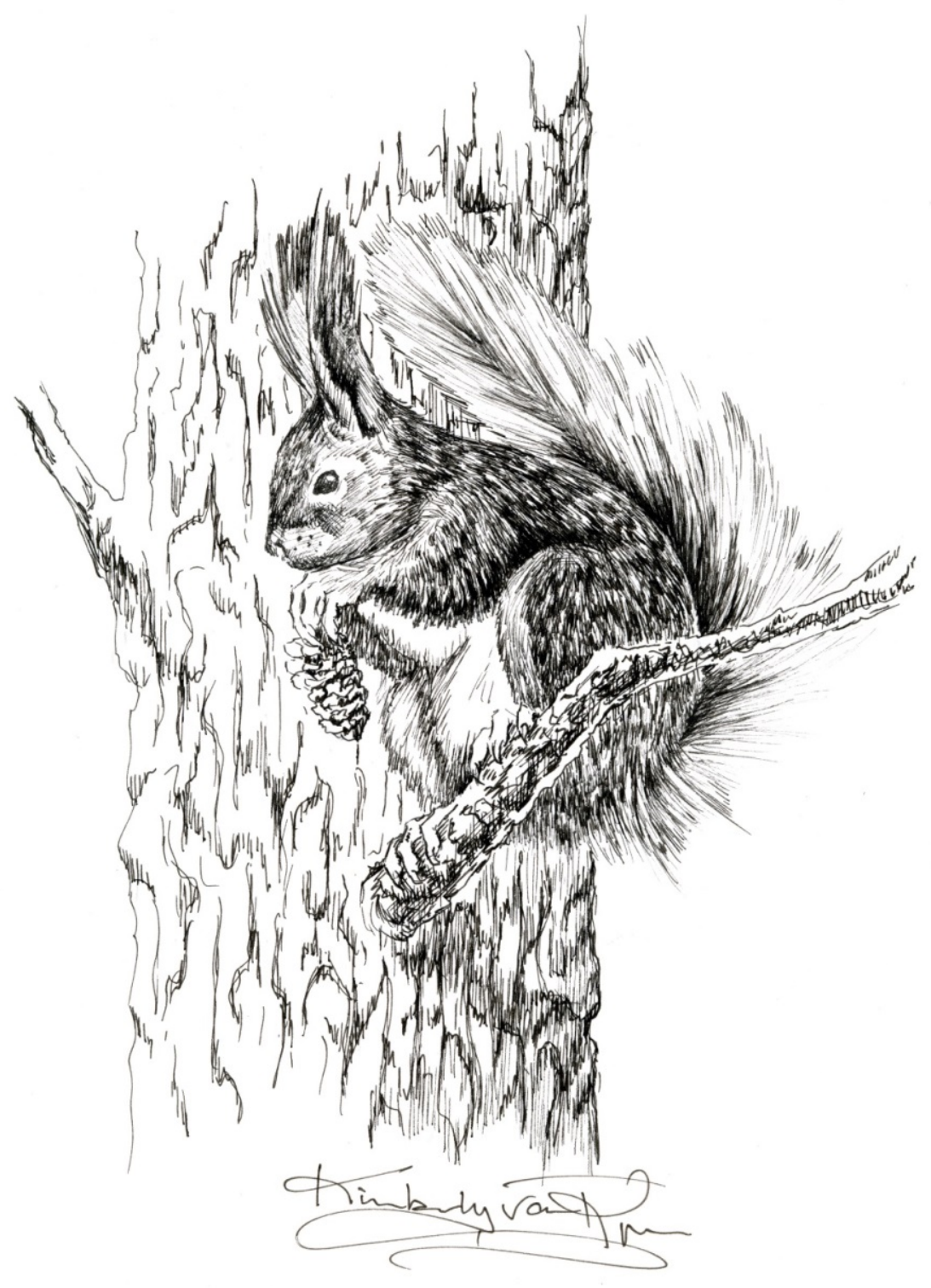

Drawing of tasseleared (Abert's) squirrel, Sciurus aberti (copyright and courtesy of Kimberly Ann van Riper). 


\title{
Proceedings of the Eighth Biennial Conference of Research on the Colorado Plateau: Integrating Research and Resources Management for Effective Conservation
}

\author{
Edited by Charles van Riper III and Mark K. Sogge
}

In his book review of the Sixth Colorado Plateau Biennial Conference Proceedings: "The Colorado Plateau: Cultural, Biological and Physical Research," Fleming (2006) closes with the following statement: "A synthesis chapter by the editors on the issue of human impacts would have been a welcome addition to this potentially useful book." The following synthesis chapter provides that addition to this Eighth Proceedings, summarizing and integrating material from all previous chapters and also utilizing information from previous books published in the Colorado Plateau series. In addition to providing a synthesis, another goal of this chapter is to demonstrate how aspects of research have been used to enhance biological and cultural resource management.

This book is the eighth (and the third volume published by the University of Arizona Press) in a series of compilations that focus on the Colorado Plateau. These books highlight the integration of research into resource management efforts, as related to cultural, natural, and physical resources within the biogeographic province. The mix of chapters addresses management issues from many diverse resources and from disparate regions of the Colorado Plateau, specifically focusing on aspects of vegetation and wildlife research, combined with a series of chapters explaining integrative and collaborative tools that can be used to better manage natural and cultural resources on smaller and larger scales.

The 20 previous chapters in this book were selected from scientific presentations at the Eighth Biennial Conference of Research on the Colorado Plateau. The conference was held 7-10 November 2005 in Flagstaff, Arizona, hosted by the U.S. Geological Survey Southwest Biological Science Center's Colorado Plateau Research Station and the Center for Sustainable Environments at Northern Arizona University. The meeting theme revolved around research, inventory, and monitoring of lands over the Colorado Plateau, with a focus on the integration of research into resources management actions. Material presented in this book represents original research that has not been previously published, and every chapter contains a section on how that research can be best implemented by managers. Each paper selected for publication has been anonymously peer reviewed by at least two scientists from that specific research discipline. These contributed scientific studies each constitute a separate chapter, with the material subdivided into seven sections within the book: 1) Introduction and Acknowledgements, 2) Collaborating to Achieve Conservation, 3)Assessing Large-scale Land-use Issues, 4) Addressing Wildlife Issues, 5) Addressing Vegetation Issues, 6) Gaining Insights From the Past, and 7) Synthesis.

The scientific works published in this Biennial Conference Series contribute significantly to presenting peer reviewed results of collaborative efforts among scientists and land managers. The U.S. Geological Survey Southwest Biological Science Center's staff, university, and other partner agency scientists have worked closely with Colorado Plateau land managers from a variety of state and federal agencies, as well as from the private sector to achieve remarkable management results. Many of the protocols and techniques presently being utilized in land management units over the Colorado Plateau are a result of previous collaborative works published in this series of books. It has been clearly 
demonstrated that, because of similarities across the Colorado Plateau, techniques that work in one management unit can be applicable to many other areas. This is due primarily to the similarity of habitat and climatological conditions over the Colorado Plateau.

\section{Collaborating to Achieve Conservation}

Collaboration is a critical component of almost every successful large-scale conservation effort. The opening chapter by Tilt et al. highlights the importance of collaborative efforts, a theme that is carried throughout this section of the book. The authors structure this opening chapter under the 11 lessons that they feel are critical for successful collaboration to occur: 1) Understand what collaboration is and is not, 2) Recognize challenge and time involved, 3) Exhaust traditional approaches (ripeness), 4) Build a common vision (passion for place, a community of purpose), 5) Create an open, inclusive, and transparent process, 6) Ensure stakeholders are representative of the community, 7) Provide facilitation and process, 8) Develop a common factual base, 9) Secure operational funding 10) Achieve and communicate results, and 11) Meet or exceed applicable laws and be accountable. They illustrate aspects of successful partnerships with a series of stories throughout the western United States, focusing on successes of Community-Based Collaboratives (CBCs). The one $\mathrm{CBC}$ that they feel has created a benchmark, and is the present standard for the Colorado Plateau, is the Diablo Trust. A background on this collaborative can be found in previous chapters of the Colorado Plateau book series (e.g., Sisk et al. 1999, Loeser et al. 2001). Initially founded in 1993 by two ranches, the Bar-T-Bar and Flying M, the Diablo Trust CBC was created to link private and public values under one holistic goal: "to create sustainable rangeland management that maintains the tradition of working ranches and provides for economic viability while managing for ecosystem health." The focus area of this CBC is east of Flagstaff, Arizona, encompassing checker-boarded private and state lands, augmented with U.S. Forest Service summer grazing allotments. Collaborators of the Diablo Trust now include local ranchers, state and federal agencies, scientists, environmentalists, and other interested stakeholders.

Working with researchers at Northern Arizona University and Prescott College, and with the many products that have been produced in this Biennial conference series (e.g., van Riper 1995, van Riper and Deshler 1997, van Riper and Stuart 1999, van Riper et al. 2001, van Riper and Cole 2004, van Riper and Mattson 2005), the Diablo Trust is one of the premier examples of a CBC that incorporates research and monitoring into rangeland conservation. One aspect that has led to the success of the Diablo Trust is the recognition that good land stewardship incorporates the integration of research into monitoring projects. Working with scientists in a collaborative environment has helped the Diablo Trust develop appropriate research questions that are relevant to the ranchers, while addressing perceived conflicts among stakeholders and the outside public (Sisk et al. 1999). In addition, integrated collaborative research and sound monitoring protocols can generate clear measures of effectiveness and progress from which to evaluate the success of any collaboration (Muñoz-Erickson and AguilarGonzalez 2003).

As Tilt et al. clearly point out, the Diablo Trust CBC has yielded several benefits to scientists. This collaboration provides scientists with a landscape of resources at multiple scales that allow their studies to go from small plots to whole landscapes. In addition, the ability to collaborate with the people who manage the land results in more meaningful, insightful, and more useful science (Sisk and Palumbo 2005). It must be recognized by scientists that, in order to continue this fruitful relationship among stakeholders, they must be willing to invest significant time into the collaborative process and anticipate a multi-decadal relationship. On the other hand, stakeholders and land owners must share a goal of sustaining research and monitoring over long time periods in order to generate information that is 
relevant to an ecological system that is often typified by slow responses interrupted by periodic bouts of dramatic change.

Although collaborations have their challenges and critics, Tilt et al. present outcomes and experiences of numerous CBC efforts reaffirming that a collaborative process can be successful in developing long-term solutions for natural resource issues. Drawing from the experiences of these collaborations, the authors highlight several criteria that have contributed to the CBC success. First, all collaborative processes face issues where the problem and its solution are poorly understood, where there are few scientific data and little understanding of what that information means, and where personnel and financial resources are small or nonexistent. Next, they point out that conflicting values confuse the process and innovation is often viewed as risky and expensive. Not only must collaborations bring together a diverse and representative group of stakeholders, but they must also recognize the amount of time, effort, and funding that is necessary for creating and sustaining a successful collaborative process. Finally, the authors point out the importance of gaining the trust of the stakeholders and outside interest groups, which is accomplished by maintaining an open and transparent process that incorporates research and monitoring protocols that will properly evaluate the CBC goals. It is evident from the findings presented in this chapter that the spectacular natural resources of the Colorado Plateau will continue to serve as a focal draw for new CBCs being formed in the region, thus ultimately influencing all facets of collaborative efforts from which management policies will be developed.

The collaborative theme in this first portion of the book is continued in Chapter 2, where Turner et al. present results of an effort between researchers and resource managers at Mesa Verde (MEVE) National Park. This collaborative modeling approach, called FRAME, details impacts of forest restoration policy at the park. The overall strategy of the FRAME Project was to combine the principles of collaboration with the adaptive capabilities of the U.S. Geological Survey modular modeling system (MMS), in order to develop a transportable, collaborative modeling approach to adaptive, multiobjective natural resource management. The group first collaboratively identified key system components, critical pathways, and associated conceptual models of pinyon-juniper ecosystem dynamics. They found that the recent invasion and rapid spread of cheatgrass in the park had the potential to significantly alter the fire regime by increasing fire frequency and impacting long-term vegetation successional patterns. This concern led the authors to focus on cheatgrass for their first modeling simulations. They modified the SIMPPLLE landscape model to capture key ecosystem components and dynamics of the conceptual models, which were then further refined through an iterative process in which project scientific experts helped define probabilities.

Model results presented by Turner et al. indicated the potential for frequent re-burning in the park, at intervals as short as a few years. These simulations suggested a fire rotation of approximately 45 years for the park as a whole, a dramatic change from the historic fire rotation that has previously been measured in centuries. The authors argue that such a disturbance regime would be far outside the historical range of variability for the ecosystem, and would likely lead to a substantial reduction and even local extirpation of many native plant species. They also showed that the projected changes in MVNP's fire regime would bring an increased risk of significant debris-flow events, with the potential for substantial damage to water and cultural resources. The FRAME case study at Mesa Verde National Park provided an ideal opportunity to implement and refine the principles and components of a collaborative modeling approach. By coupling principles of collaboration with integrated modeling approaches, the authors developed a collaborative modeling framework to facilitate adaptive, multiobjective resource management that would be applicable across a wide range of ecosystems. 
We now see across the Colorado Plateau, trends in public and private lands management toward integrated science approaches, with co-management of public lands, adaptive management in the face of uncertainty, and public engagement in land-use decision making, developed primarily in response to a greater appreciation of the inherent complexity and uncertainty in natural systems. We are also seeing an increased public scrutiny of decisions on public lands. The authors have developed their FRAME collaborative modeling approach to address these challenges faced by natural resource managers, and to provide those managers with mechanisms to effectively link integrated science to natural resource management needs. The FRAME approach can also readily be adapted to engage the public in participatory natural resource management efforts, and the authors demonstrate that this collaborative process could easily be applied to most management units over the entire Colorado Plateau.

\section{Addressing Large-Scale Land-Use Issues}

At this point, the book departs from the arena of the Citizen-Based-Collaboratives and moves into large-scale land management issues. The next three chapters focus on aspects of the GAP program, a computer-based Geographic Information System (GIS) tool initially developed by J. Michael Scott (Scott et al. 1993), a U.S. Geological Survey scientist at the University of Idaho. A number of research studies utilizing GAP have been published in chapters of previous books within the Colorado Plateau series (see especially the volumes of van Riper et al. 2001, van Riper and Cole 2004, van Riper and Mattson 2005). The GAP program provides information on ecosystem representation by creating digital maps of conservation networks, providing an account of the representation of elements of biodiversity within a region (Crist and Scott 1999). Gap analysis uses the distribution of vegetation types and vertebrate species as indicators of biodiversity. Digital map overlays in a GIS are used to identify individual species, species-rich areas, and vegetation types that are absent or underrepresented in existing management areas (Scott et al. 1993). These products are used to develop conservation strategies and to predict contributions of new management areas for biodiversity maintenance at landscape scales (Scott et al. 1991).

In Chapter 3, Ernst and Prior-McGee argue that the conservation of biological diversity is important for the maintenance of naturally functioning ecosystems, and to ensure preservation of species and communities as well as functional diversity of plant and animal populations. The Colorado Plateau is perhaps one of the most diverse ecoregions in North America and is characterized by unique geology and landform features that create an environment that results in high endemism. Ernst and Prior-McGee demonstrate that the vulnerability and conservation of these unique Colorado Plateau resources can be adequately evaluated by the use of the Southwest Regional Gap Analysis Project (SWReGAP) stewardship dataset, and that the information provided can effectively assess general patterns of biodiversity protection within this ecoregion. They point out that this evaluation is important because federal agencies and tribal land stewards manage the majority (over 75\%) of the Colorado Plateau (The Bureau of Land Management manages $31 \%$ of the ecoregion, the National Park Service $7 \%$, and the Forest Service (USFS) 4\% of the ecoregion), and maintenance of biodiversity with federal land management is easier to accomplish when compared to working with a mosaic of land-ownership patterns.

In examining degrees of protection, Ernst and Prior-McGee identified land management categorization schemes relative to the purported degree of management for biodiversity maintenance for each managed area. They listed four biodiversity management status categories as defined by Scott et al. (1993), Edwards et al. (1994), and Crist et al. (2000):

- Status 1: An area having permanent protection from conversion of natural land cover and mandated management plan in operation to maintain a natural state within which disturbance 
events (of natural type, frequency, intensity, and legacy) are allowed to proceed without interference or are mimicked through management.

- Status 2: An area having permanent protection from conversion of natural land cover and a mandated management plan in operation to maintain a primarily natural state, but which may receive uses or management practices that degrade the quality of existing natural communities, including suppression of natural disturbance.

- Status 3: An area having permanent protection from conversion of natural land cover for the majority of the area, but subject to extractive uses of either a broad, low-intensity type (e.g. logging) or localized type (e.g. mining). It also confers protection to federally listed endangered and threatened species throughout the area.

- Status 4: There are no known public or private institutional mandates or legally recognized easements or deed restrictions held by the managing entity to prevent conversion of natural habitat types to anthropogenic habitat types. The area generally allows conversion to unnatural land cover throughout.

The authors found that approximately $5 \%$ of the Colorado Plateau ecoregion has permanent protection (GAP Status 1) from conversion of natural land cover to anthropogenic land cover types. The National Park Service manages $90 \%$ of the Status 1 lands with the largest parcels including Grand Canyon, Canyonlands, Zion, and Arches National Parks. The BLM manages 7\% of the Status 1 lands, with most occurring as small and isolated parcels in the form of administratively designated Areas of Critical Environmental Concern (ACEC) and Outstanding Natural Areas (ONA). The U.S. Forest Service (USFS) manages 3\% of the Status 1 lands, the largest being the Kanab Creek Wilderness, and The Nature Conservancy manages 1\%. On the Colorado Plateau, the state of Arizona manages $63 \%$ of the Status 1 lands, while Utah manages 33\%.

Status 2 lands constitute $12 \%$ of the Colorado Plateau with $85 \%$ of those lands managed by the BLM. Approximately $60 \%$ of the Colorado Plateau is managed as Status 3 lands (primarily multiple-use lands), with 57\% being tribal lands and 33\% BLM. Additionally, 23\% of the Colorado Plateau is managed as Status 4 lands, which are primarily privately-owned lands (62\%) which have no known mandates that limit natural land cover conversion to anthropogenic land uses. The information provided by this chapter will be effective in identifying land areas that are presently being managed for biodiversity and their levels of protection over the Colorado Plateau. These data will also assist in the evaluation of what lands are presently providing for maintaining biodiversity on the Colorado Plateau. By helping managers identify locations of conservation lands, and the stewards of those lands, the GAP program allows those managers to better place their parcel into a regional perspective. When the land stewardship data are combined with information on vegetation and species richness, land stewards can then evaluate how well their areas are contributing to protecting biodiversity over the Colorado Plateau.

The interface between conservation and aspects of resource management, utilizing the GAP program, is further developed in Chapter 4 by Langs et al. These authors build upon the framework of the previous chapter, providing the reader with the first mapping of natural land cover across the Colorado Plateau using ecological systems. They conducted a gap analysis for the Colorado Plateau ecoregion through a geospatial union of key environmental and management data layers using ESRI ${ }^{\circledR}$ ArcGIS Desktop 9 software and Spatial Analyst extension. Their input data consisted of three spatial databases developed by SWReGAP: land cover, land stewardship, and biodiversity management status categories. The stated goal of this chapter was to provide land managers and policy makers with information needed to make better-informed decisions when identifying priority areas for conservation.

Langs et al. documented 77 different land cover types that occur within the Colorado Plateau ecoregion, 62 of which they determined to be ecological systems. Only seven of the 62 ecological 
systems had greater than $5 \%$ of their mapped distribution within the Colorado Plateau ecoregion, which when combined represents approximately $75 \%$ of the total area. They also found that 48 of the ecological systems had $1 \%$ or less distribution within this ecoregion, of which, 40 have $5 \%$ or less of their regional distribution within the Colorado Plateau. These ecological systems have either naturally restricted ranges, or although common, are considered peripheral to the Colorado Plateau.

The seven most abundant ecological systems on the Colorado Plateau were the Colorado Plateau Pinyon-Juniper Woodland (23\% of the ecoregion), Inter-Mountain Basins Semi-Desert Shrub-Steppe (11\%), Colorado Plateau Mixed Bedrock Canyon \& Tableland (11\%), Inter-Mountain Basins SemiDesert Grassland (8\%), Inter-Mountain Basins Mixed Salt Desert Scrub (7\%), Colorado Plateau Blackbrush-Mormon-tea Shrubland (7\%), and Inter-Mountain Basins Big Sagebrush Shrubland (6\%). There were five ecological systems they considered "nearly endemic" to the Colorado Plateau. These near endemics include: Southern Colorado Plateau Sand Shrubland (99.7\% of its mapped distribution falls within the ecoregion), Colorado Plateau Blackbrush-Mormon-tea Shrubland (99.6\%), Colorado Plateau Mixed Bedrock Canyon and Tableland (86\%), Inter-Mountain Basins Mat Saltbush Shrubland $(82 \%)$, and Inter-Mountain Basins Shale Badland (82\% of its mapped distribution falls within the ecoregion).

The use of conservation thresholds allowed Langs et al. to identify ecological systems with low representation in Status 1 and 2 lands (explained by Ernst and Prior-McGee in the previous chapter). Langs et al. also identified six ecological systems with minimal protection within the ecoregion. On the other hand, they point out that there are many ecological systems within the Colorado Plateau that are either barren, sparsely vegetated, or have open-canopied scrubby vegetation (West and Young 2000). These systems occur on soils that are easily erodible such as sand sheets, dunes, and shale badlands. Wind and water degradation of the soil leads to degradation of the vegetation supported in these substrates. The presence of cryptogramic crusts plays an important role for many of these systems by facilitating the infiltration of water, increasing fertility, and reducing erosion of the soil (Belnap et al. 2001). The authors also point out that drought, coupled with increasing temperatures pose a near-future threat to the ecological systems of the Colorado Plateau.

In carrying through the earlier CBC theme of this book, Langs et al. point out that conservation at ecoregional (aka larger) scales requires the involvement of multiple partners and cooperative management among diverse land stewards. Partnerships with federal land management agencies, tribal entities, private land owners, academic institutions, and non-government organizations all play a vital role for ensuring successful, long-term conservation within the Colorado Plateau (Tuhy et al. 2002). One example that the authors highlight as an example of a CBC partnership that includes the Colorado Plateau, is the Utah Partners for Conservation \& Development (UPCD). This CBC is composed of state, federal, and natural resource agencies, universities, county and local governments, private land owners, conservation organizations, and other vested stakeholders, who are working cooperatively to manage and restore rangelands in Utah (Utah Division of Wildlife Resources 2005). By having CBC groups utilizing Regional GAP data, and by analyzing land-cover over the entire Colorado Plateau, land managers can strike a balance between biodiversity management with anthropogenic impacts, including development potential. The next chapter serves as a summary of the large-scale land management section, as well as a transition into the Biological portion of this book. Boykin et al. incorporate protocols from the GAP program to create Geographic Information System (GIS) models that map the distributions of wildlife over the Colorado Plateau. The authors use seven foundation GIS layers, ranging from dominant over story vegetation, through slope and aspect, to tree density and basal area, to develop their models. From a survey of 40 academic institutions, they also provide a list of sensitive species that is incorporated into their model as a separate data layer. They then developed habitat 
models from literature reviews for each species using specific associations of available GIS environmental variables. Specific variables that they used included land cover, elevation, slope, aspect, distance to hydrological features, landform (after Manis et al. 2001), soils, and mountains. Models were constrained to the known range of the species using state, regional, and national references. Range data were converted to sub-basin watershed units (8-digit hydrologic units) using the National Hydrography Dataset (Boykin et al. 2006; see http://nhd.usgs.gov/).

Throughout Chapter 5 Boykin et al. point out that GAP analyses for vertebrate species is a process of intersecting habitat models with a dataset of land stewardship that identifies levels of longterm conservation management. They provide spatial habitat models for 817 vertebrate species for the region comprising Arizona, New Mexico, Colorado, Utah, and Nevada, finding that total species richness was highest in areas of the Colorado and San Juan River drainages. They also demonstrate that patterns of richness vary among different vertebrate groups and subgroups, for example between the herpetofauna, bats, and large mammals. The information in this chapter was collected throughout the entire biogeographic province of the Colorado Plateau, from along the Mogollon Rim in the south to the White Mountains in eastern Arizona, up to the Green River in northern Utah, and west to the Mojave Desert, so land managers over the entire biogeographic region will find this information useful.

The authors then provide an in-depth example of how their habitat model might be used, taking 19 amphibians with predicted habitat on the Colorado Plateau (51\% of all amphibians modeled in the region), 341 birds (78\%), 143 mammals (67\%), and 78 reptiles (60\%). They provide full results for the vertebrate models, including references, habitat data, modeling process, and textual and spatial models. The authors also calculated total species richness from the SWReGAP data for the Colorado Plateau, and found an average between 354-390 animal species per drainage sub-basin. Species richness was higher in the eastern portion of the Colorado Plateau, with animals associated with the San Juan Mountains and the San Juan River, and on the Western side of the plateau along the Colorado and Virgin Rivers. Compared to the entire SWReGAP region, Boykin et al. found that species richness on the Colorado Plateau was intermediate, with higher richness than more northern areas, but lower richness than Southern Arizona, much of New Mexico and the Colorado Rocky Mountain Front Range. The data contained in Chapter 5 provides baseline information for conservation of animals over the entire Colorado Plateau, particularly when combined with other current inventory efforts. This chapter provides another useful tool for managers to better assess large-scale land-use issues over the Colorado Plateau, and this sound scientific tool can be used to enhance understanding of vertebrate distributions on the Plateau, and within the context of those species' habitats throughout Southwestern North America.

\section{Addressing Wildlife Issues}

This section of the book brings a focus to wildlife issues, and to addressing management concerns within this group of organisms over the Colorado Plateau. Chapter 6 serves as an introduction to wildlife issues, providing a historical account of the pronghorn antelope in Arizona, with a focus on Anderson Mesa. No area in Arizona is more frequently associated with pronghorn than the Anderson Mesa Game Management Unit. More than 25\% of all of the pronghorn in the "Millennium" edition of the Arizona Wildlife Trophy Book either came from this unit, or from areas restocked with animals from Anderson Mesa (Lewis 2000). Three of the top five pronghorn trophies in the Boone and Crockett Club's North American Record Book are from Coconino County where Anderson Mesa is located (Byers and Bettas 1999). Anderson Mesa was the site of Arizona's first legal pronghorn hunt and has been a focal point for pronghorn studies since the early 1930s. Pronghorn studies on Anderson Mesa have ranged from developing survey and capture methodologies (Wilkins and Welles 1944, Edwards 
1947, Wallmo 1951), determining seasonal food habits (Gay 1984), and evaluating reproductive performance (Erling 1956a, 1956b), to evaluating the effects of coyote control and other factors on fawn recruitment (Arrington 1947, Arrington and Edwards 1951, Neff and Woolsey 1980, Neff et al. 1985).

Brown provides a detailed history of the increases and declines in pronghorn recruitment rates and of the population sizes on Anderson Mesa. He documents that in the 1970s, declining pronghorn numbers resulted in an intensive study to determine if aerial gunning of coyotes could improve pronghorn numbers on Anderson Mesa. Although aerial gunning was expensive and politically unpopular, Brown concluded that these studies indicated pronghorn fawn recruitment could be improved by applying such control practices, as did Neff and Woolsey (1980) and Neff et al. (1985). When pronghorn recruitment and population numbers again declined in the 1990s, however, coyote reduction efforts were no longer deemed an effective solution, and since that time pronghorn recruitment on Anderson Mesa has been below herd maintenance levels (Yoakum 2003). Since the early 1900s pronghorn populations on Anderson Mesa have declined several times then rebounded, demonstrating that the species is highly adaptable. But whether pronghorn on Anderson Mesa can again attain their former numbers is problematical, and Brown argues that these animals are now subsisting on a declining forage base due to excessive elk and livestock use. He concludes this chapter by saying that sportsmen, ranchers, and the general public will have to press management agencies to reduce ungulate pressures and improve forage quality if mean annual pronghorn recruitment rates are to again exceed maintenance levels.

In Chapter 7, pronghorn antelope home range and the effects of Interstate 40 and the BurlingtonNorthern and Santa Fe (BNSF) railroad is examined at Petrified Forest National Park (PEFO). The impact of transportation corridors on pronghorn in northern Arizona was first identified in the Colorado Plateau book series (Ockenfels at al. 1997), and later further detailed by van Riper and Ockenfels (1998) and then Bright and van Riper (2000). Hart et al. build upon these earlier studies by establishing an experimental field-study that examines the potential, non-lethal effects of transportation corridors on the basic ecology of pronghorn. The authors looked specifically at the one pronghorn herd that Ockenfels at al. (1997) documented as isolated, under comparatively unique conditions where Interstate 40 and the BNSF railroad constituted near impenetrable barriers. Hart et al. designed a manipulative study where fences were modified in an attempt to see if pronghorn would expand their home range, with the hope that by removing fences the confined animals would move across the BNSF tracks and genetically mix with other pronghorn in the park.

After two years of manipulative studies, the authors' efforts were not successful in changing movement patterns of the targeted pronghorn herd. The authors found, even after fence modification, consistent pronghorn avoidance of the I-40 freeway and BNSF features, diminishing the odds that exploratory behavior would result in chance crossings. The isolated pronghorn at the park appear likely to remain so for the foreseeable future given the frequency of the train traffic and its inherent disturbance, as well as the other potential physical and psychological deterrents associated with the right-of-way. The authors state that it may ultimately be necessary to use overpasses or underpasses to enable pronghorn to negotiate these two transportation corridor barriers. However, they still believe that efforts to modify the right-of-way to enhance the potential for pronghorn crossings, such as those employed in this study, may have merit if the scope of the effort can be expanded both spatially and temporally. Given the high costs associated with creating structures to span or tunnel beneath the railroad, the management recommendation of this paper encouraged further investigation of the potential to enhance direct crossings of the right-of-way before more complicated and costly measures are pursued. 
In Chapter 8 Wakeling and Riddering examine bighorn sheep being released in habitats based on a priority ranking system, and the possibility of differential mountain lion predation on those sheep. The authors agree that it seemed logical to assume that releases in lower quality habitats would have lower survival and higher cause-specific mortality, but their analyses failed to support that assumption. They argue that a possible reason for the lack of a relationship to survival and the presently utilized priority ranking system is that habitat quality must fall below a critical threshold before bighorn survival is directly affected. The authors also point out that all past bighorn sheep releases have occurred primarily within the range of suitable habitats that are all above this critical threshold. Cunningham's (1989) original speculation that habitat must score $>50$ to be suitable must be incorrect, because they found that bighorn sheep were capable of sustaining themselves in habitats that score as low as 40 .

An alternate explanation that the authors explore in this chapter is that habitat quality scores that the Arizona Game and Fish Department presently use to identify bighorn sheep translocation sites are not good predictors of true bighorn habitat suitability. This latter rationale, however, seems unlikely because several studies have tested the suitability ranking method and found that these techniques are fairly reliable in selecting suitable bighorn habitats (e.g., Wakeling and Miller 1990). Most of the habitats where bighorn sheep releases have occurred scored over 40 points using the CunninghamBrown criteria, and the highest quality habitat in this evaluation received a score of 55 . Moreover, habitats that received a numerical score in excess of 34 were not correlated with survival or mortality. Further, Wakeling and Riddering question the use of translocated animals as an effective surrogate for survival of resident bighorn sheep populations. The chapter also provides an analysis of data that examines the question "Do increases in mountain lion predation cause declines in bighorn sheep numbers?" Based on measured survival rates for translocated bighorn sheep populations, the authors point out that their analysis on survival and habitat quality did not support the hypothesis that translocations into lower ranking habitats influenced mountain lion predation on, or survival of, bighorn sheep.

The next two chapters cover management aspects of avian resources on the Colorado Plateau. Chapters 9 by John Spence, and Chapter 10 by Hurteau and her collaborators, deal with birds in Grand Canyon National Park and on U.S. Forest Service lands in northern Arizona, respectively. Spence, who works as a Resource Manager in Glen Canyon National Recreation Area, has spent many years monitoring bird activities along the Colorado River. In Chapter 9 he analyzes five years of breeding bird survey data from the Colorado River between Glen Canyon Dam and upper Lake Mead. The principal emphasis of that program was to develop a baseline data set on relative abundance of riparian species, in order to develop a standardized methodology to monitor birds in riparian vegetation, and to examine aspects of statistical power in those data. Spence uses data from selected species to illustrate the relationships between relative abundance measures, abundance variability over time, and statistical power. He provides a quantitative model of avian community structure along the Colorado River in two national parks, and a power analysis related to the ability to accurately count birds, given differing avian guild assemblages and existing habitat structures associated with the Colorado River corridor.

Avian communities along the Colorado River have changed substantially since completion of Glen Canyon Dam in 1963, as pre-dam vegetation along the river consisted of a thin riparian strip controlled primarily by spring flooding (Carothers and Brown 1991). Extensive stands of riparian habitat have become established on silt terraces where the Colorado River drains into Lake Mead. These recent habitat modifications have caused changes in the avian community (Brown et al. 1987). The monitoring program that Spence details in this chapter was established to provide data necessary to adaptively manage dam operations in order to minimize impacts to selected resources (NRC 1999). He points out that various monitoring programs had been established as part of the environmental impact 
studies since 1982, under management of the Glen Canyon Environmental Studies Program (NRC 1987, 1996), and a number of these studies have appeared as chapters in this Colorado Plateau book series (e.g., Felley and Sogge 1997). The avifauna, principally riparian breeding birds, Bald Eagle (Haliaeetus leucocephalus), and the endangered Southwestern Willow Flycatcher (Empidonax traillii extimus), have been an integral part of past and ongoing monitoring studies along the river corridor (van Riper and Sogge 2004).

Spence points out that many birds are considered as good indicators of ecosystem change, as they can respond quickly to changes. Such changes could be in response to climatic variation, invasion of the ecosystem by a new exotic species, recreational-based disturbances, changes in prey-base, management practices, or some combination of these factors. Due to the strong tendency of passerine birds to exhibit pronounced habitat selection (Hilden 1965, Cody 1985), Spence suggests that birds can be a useful group of organisms for monitoring habitat effects in a dynamic system such as the Colorado River. Two of the major forcing variables presently controlling the Colorado River riparian system are quantity and timing of dam releases, so it is likely that most breeding birds are responding to changes in vegetation rather than to fluctuating river flows. By monitoring avian populations, changes in other components of the riparian ecosystem may be detected, and management practices can be developed to address any potential problems.

The principal goal of the study that Spence details in Chapter 9 was to determine whether a longterm monitoring program with adequate statistical power could be developed to detect trends in the riparian breeding bird community along the Colorado River. Power analysis is a necessary and important tool in the establishment of any monitoring program and is particularly critical in the case of endangered species monitoring, as the failure to detect a decline may have disastrous consequences (Taylor and Gerrodette 1993). Most natural wildlife populations vary from year to year in abundance and this variation can result from numerous complex and interacting factors. In this study, Spence found that the power to detect change in less than 10 years only existed for a few species, such as Lucy's Warbler and Bewick's Wren, and only for very large effect sizes. Hence, long-term commitment of substantial financial and human resources would be needed to detect statistically defensible trends in the riparian bird community along the Colorado River. Such long-term commitments of time and resources are still rare in bird monitoring programs.

Spence also points out that it is important to understand that bird abundance within the study area is affected by numerous other variables outside the Colorado River corridor. The most important among these are winter and migration habitat changes and winter habitat climate variability, both of which strongly influence bird survivorship. Glen Canyon Dam operations affect birds primarily through effects on breeding habitat, but under normal operations these impacts are likely to be fairly minor compared with climate and habitat changes outside the Colorado River corridor. The major impacts of dam operations are the planned or unplanned floods, including those in 1983 and 1996. These floods can potentially scour out much of the riparian vegetation along the river corridor. Past flooding, particularly that in 1983, may explain many of the present differences found in the breeding bird communities between the mid-1980s and Spence's study, as riparian vegetation extent was much reduced after the 1983 event (Spence 2004, Holmes et al. 2005).

In summary, Spence demonstrates that in more temporally variable avian species it is often difficult to detect subtle long-term trends because of the natural variability in bird populations. His power analysis provided a measure of how well the monitoring program could detect a trend through variability in the monitoring data. In the absence of an estimate of the power of a monitoring program, resource managers and scientists cannot always know if change in a population (or species of interest) is statistically significant. Furthermore, without adequate power, managers may not be able to detect a 
significant change in a rare species that may be of management importance. This study used the approach of "prospective" power analysis (cf., Steidl et al. 1997), in which preliminary baseline data on population numbers and variability is gathered over a period of time, and is then, in turn, used to design an effective long-term monitoring program, examining factors like sample size considerations, sampling protocols, and duration of data collection. Although this model of predicted bird occurrence was developed along the Colorado River corridor, the technique would be widely applicable to other areas over the Colorado Plateau.

In the second bird chapter, Hurteau et al. document that in the past century forest management practices have significantly altered the function and structure of southwestern ecosystems that are dominated by ponderosa pine (Pinus ponderosa). There have been significant portions of earlier books in the Colorado Plateau series devoted to this subject (e.g., Garrett et al 1997, Garrett and Soulen 1999, Bailey et al. 2001), all pointing out that fire suppression, grazing, and logging have resulted in a dense, closed canopy forest with an increased susceptibility to stand-replacing wildfire. Mechanical thinning and prescribed fire are important tools used in fuel reduction treatments, and can mitigate the threat of stand-replacing wildfire. However, the effects of these practices on wildlife communities are poorly understood. The authors explain that the Fire and Fire Surrogates (FFS) Program is a national study that seeks to quantify the effects of prescribed fire and mechanical thinning on numerous response variables, including wildlife. On three FFS Southwestern Plateau sites in northern Arizona, Hurteau et al. examined the short-term (3 years) avian community response to experimental thinning and prescribed fire treatments. For a suite of focal species selected from the total avian community, they evaluated changes in abundance and density resulting from different treatment types. Their results suggested that patterns in ranked avian abundance among treatments were significantly correlated, and that overall community structure was generally not affected by fuel reduction treatments, regardless of treatment type.

Among a suite of focal species, the authors found that response to specific treatment types was more variable. For example, Western bluebird (Sialia mexicana) and dark-eyed junco (Junco hyemalis) densities increased in response to thinning and fire, alone and in combination. Mountain chickadee (Poecile gambeli) density decreased dramatically in all treatment types in the post-treatment period, while the pygmy nuthatch (Sitta pygmaea) exhibited a decrease in density during this same period. They also found that the Yellow-rumped warbler (Dendroica coronata) exhibited a negative response to the thin only treatment but a positive response to the burn only treatment. Considering the wide spectrum of avian community attributes that the authors measured, their results provide essential baseline information for project-level planning. Moreover, their research provides evidence that perhaps the avian community may not be responding to fuel reduction treatments as previously believed. The authors' overarching conclusion was a recommendation that forest managers implement a mosaic of treatment types so as to best preserve avian habitats in ponderosa pine forests on the Colorado Plateau.

The next two chapters focus on other groups of vertebrates on the Colorado Plateauherpetofauna and native fish. In Chapter 11 Trevor Persons and his colleagues provide a summary of the present status and historic changes of all reptiles and amphibians (herpetofauna) in national parks over the southern Colorado Plateau. This chapter provides a much needed summary of numerous years of a biological inventory that has been undertaken at national park service sites. Although many national park areas on the Colorado Plateau were created primarily to protect remarkable deposits of cultural resources, the authors point out that these parks also preserve a diverse assemblage of vertebrate species. The inventory work outlined in this chapter began in 2000 when the National Park Service (NPS) initiated a nationwide program to inventory vertebrates and vascular plants within the parks. As part of this new inventory effort, a total of 265 National Park units (parks, monuments, recreation areas, 
historic sites, etc.) were identified as having significant natural resources, and these were divided into 32 groups or "networks" based on geographical proximity and similar habitat types. The many NPS areas on the Colorado Plateau of Utah, northern Arizona, northwestern New Mexico, and western Colorado were divided into Northern and Southern Colorado Plateau networks. In this chapter Persons et al. summarize the results of their amphibian and reptile inventories at 19 parks within the Southern Colorado Plateau Inventory and Monitoring Network. They synthesize distribution and habitat information for all amphibian and reptile species across that network, with the primary goal of their complete species inventory to document at least $90 \%$ of the species present at each park. To evaluate their progress toward that goal, they provide an estimated level of inventory completeness for each park. This chapter also provides an exhaustive checklist of all possible herpetofauna found over the southern Colorado Plateau, with an estimated level of inventory completeness for each species. The authors close the chapter with a list of considerations for future inventory work.

Chapter 12 details a unique application of inventory techniques, documenting fish species assemblages along drainages that have been disturbed by fire. Jonathan Long examines the potential impact that a forest fire in KP and Grant Creeks within the White Mountain Apache reservation, had on native Apache trout. These streams extend into mixed conifer forests where mixed severity wildfires such as the KP and Steeple Fires are typical. The two drainages are similar in geology, topography, and vegetation, and are similar to the majority of streams planned for recovery of Apache trout. Fish extirpations have been reported from streams in drier, lower-elevation forest types where wildfires have been more severe. However, long-term fire history studies suggest that high severity wildfires do occur in high-elevation forest types during extended dry periods.

Long, and his colleagues at the U.S. Forest Service Rocky Mountain Research Station, sampled fish populations and habitat conditions at seven 50-m long sampling sites in KP and Grant Creeks in June 2004 after the KP Fire was contained. Fish populations were re-sampled at six of the sites one year later. They also attempted to relocate sites that had been previously sampled for fish in September of 1995 by the Arizona Game and Fish Department (AGFD), as part of their General Aquatic Wildlife Surveys (GAWS) program. Fish populations were sampled using backpack-mounted electro-shocking gear. Each reach was blocked off with nets to prevent fish from escaping during sampling and was sampled three times using the depletion method. They found that trout populations persisted following the mixed severity wildfires in KP and Grant Creeks. These findings indicate that evacuation of populations, which is now standard procedure, may not be necessary at the higher elevations when a watershed is not severely burned. While many factors can influence the likelihood of fish persistence, Long suggests that burn severity can be determined through the use satellite imagery and until more confirmatory studies are conducted, the satellite imagery metric may help managers to quickly evaluate whether to evacuate Apache trout populations that are threatened by wildfires.

The final chapter that addresses wildlife issues deals with managing invertebrates within caves on the Colorado Plateau. Wynne et al. point out that cave environments are among the most fragile and understudied ecosystems on earth. From what scant information they can find, only limited research seems to have been conducted on caves in Grand Canyon National Park and over the southern Colorado Plateau. The authors reviewed all available literature and park cave trip reports, representing nine studies of 15 caves at Grand Canyon National Park. Chapter 13 lists approximately 37 cave dwelling invertebrates that are known to occur in Grand Canyon caves, including three troglobites, six trogloxenes, 14 troglophiles, one stygobite, 10 unknown cavernicoles, and three "special case" species. Previously, only four cave-adapted taxa were known to occur in the Grand Canyon. The authors also provide an annotated checklist of all known invertebrates from caves over the Colorado Plateau. Because this information represents data on only about $5 \%$ of the known caves in Grand Canyon 
National Park, the authors suggest that more endemic cave-adapted invertebrates are expected to be discovered in the future.

\section{Addressing Vegetation Issues}

Vegetation studies are introduced into this book with Chapter 14, where Thomas et al. provide an analysis of plant community composition and structure at Petrified Forest National Park (PEFO). This is the first complete survey of all vegetation types that has been published for the park (PEFO). The vegetation of Petrified Forest NP is complex and varied, containing many dominant plants of low stature, with a rich mosaic of grasslands, steppe, and shrubland types that have different species dominating at different locations. In their description of PEFO vegetation associations, alliances, and park specials, the authors emphasized how the topography and soil types within the park are correlated with the vegetation distribution patterns that they documented. Other factors that influenced the expression of the park vegetation were drought and invasive plant species distributions. Precipitation in this area of the Colorado Plateau is bi-seasonal, with winter precipitation and a summer monsoon period. The authors found that grasses in the Park responded particularly strongly to the seasonality of precipitation. Some of the PEFO grasses showed the most growth in the spring warm up (these were cool season grasses) while others showed the most growth in response to the summer monsoons (these being warm season grasses). Climatic events that reduce precipitation during the winter, summer, or both seasons inhibit plant growth and reproduction, and may ultimately kill plants. For example, the authors point out that the drought in the southwestern U.S. in the early 2000 s greatly reduced vegetation cover at the park, as plants responded with reduced vegetative growth and dieback. Climate change, especially change that brings warmer temperatures and decreases in precipitation and/or changes in the monsoon pattern, can be expected to dramatically change characteristics of plant distribution in the park.

Thomas et al. also provide a thorough inventory of invasive non-native plants within Headquarters Mesa, the Puerco River corridor, and portions of the southern park. The authors found over 25 different invasive (non-native) plants, with the most prolific being Russian thistle that occurred in over $75 \%$ of the sampled area. Many of the earlier book chapters in the Colorado Plateau series (e.g., Floyd et al. 2001, Falzarano et al. 2005, Nabhan et al. 2005) have demonstrated that invasive plants are increasingly threatening ecosystems over the Colorado Plateau. The invasive plants not only interact with native plants and animals, but can also increase the frequency and magnitude of fires (Floyd-Hanna et al. 1999). In the event of a prolonged drought, invasive species can magnify the effects of reduced water on native species by sprouting earlier, thus removing soil moisture that would have been available for native plants. Chapter 15 moves west, from the short-grass prairie at PEFO, to the higher elevation Ponderosa Pine forests of northern Arizona. Speer and Bailey provide forest managers with information on understory vegetation responses to tree harvesting and prescribed fire in overly dense ponderosa pine forest stands. Throughout the past century, ponderosa pine forests over the Colorado Plateau have become increasingly dense; this change was brought about by Euro-American settler land-use practices beginning in the late 1800s (Covington et al. 1994, 1997, Moore et al. 1999). The current high density of ponderosa pine forests allows little sunlight for understory vegetation development (Naumberg and DeWald 1999). Continuous heavy grazing of domestic livestock and from recently expanding elk populations has further depleted a rich understory of grasses and forbs that once out-competed pine seedlings. The pre-historic understory once enabled frequent surface fires that further prohibited extensive pine regeneration (Korb and Springer 2003). In addition to supporting a natural fire regime (Laughlin et al., 2004), the earlier understory enhanced net primary productivity, nutrient cycling, and forage for wildlife communities, in addition to promoting a number of ecosystem functions including hydrology and soil stabilization (Korb and Springer 2003). Of particular interest to the authors, in 
regards to harvesting, burning, and general soil disturbance, was the introduction and spread of introduced (alien) grass species (Crawford et al. 2001, Sieg et al. 2003, Korb et al. 2004). These alien species are of importance to ecosystem function and health because they alter successional pathways by out-competing native pioneer species, thereby altering the ecosystems functions normally performed by native species (Fornwalt et al. 2003). Speer and Bailey, as also documented in the chapter by Hurteau et al., conducted their research on one of 13 sites in the national Fire and Fire Surrogate (FFS) Program. Their goal was to learn more about how perennial and annual understory plants respond to increasing intensities of management (burn only, harvest only, harvest and burn), with a focus on species richness and ground cover of native and exotic vegetation in ponderosa pine forests.

In their study, Speer and Bailey examined harvesting and burning, alone and in combination, focusing on any increases or decreases in native and alien species richness and abundance. They found that as management intensities increased (burn only, harvest only, harvest and burn), understory responses increased. In areas that were mechanically treated, understory showed significant but small increases in native species ground cover $(2-3 \%)$ and native richness ( $~ 5$ species, a $20 \%$ increase). Tree harvesting also resulted in smaller increases in alien species richness and ground cover that were significantly greater than that of their controls. Both native and alien species richness and cover responded most strongly to the combination of harvesting and burning treatments, yielding levels significantly higher than in the controls, where alien cover and native richness and cover stayed relatively consistent during the four years of their study. Burning alone stimulated insignificant increases in native species richness and cover, given only minor changes in overstory condition and relatively little site disturbance.

On their control plots, Speer and Bailey observed nine of the 15 total alien species found in this study. Occurrences of field bindweed (Convolvulus arvensis), lambsquarters (Chenopodium album), prickly lettuce (Lactuca serriola), and the common dandelion (Taraxacum officinale) all declined across sites during the four study years. They felt that this decrease in alien species richness and frequency was due to species-specific natural germination cycles of annual and biennial plants relative to their limited 2 -year sampling period. Alien species richness decreased (0.15) with time in their control areas. Several recent studies (see also results in the following book Chapter 16) clearly document that management disturbance provides a vector for alien species to colonize (Crawford et al. 2001, Seig 2003, Korb et al. 2004), but there is little documentation of a decrease in alien species richness when left undisturbed.

In response to the harvesting and burning treatments in their study design, Speer and Bailey found that more intensive management regimes yield both higher native and alien understory vegetation cover and richness. This general trend has been repeatedly documented (e.g., Crawford et al. 2001, Laughlin et al. 2004), particularly in ponderosa pine forests. The authors suggest that, if promoting a more robust understory is a desired management objective for enhancing grazing and foraging, promoting soil stabilization and nutrient cycling, influencing fire behavior, ecological restoration, or simply for aesthetics, then these goals can be achieved at different levels by changing intensities of management activities. However, the risk of invasive alien species colonizing after treatment should be weighed carefully, as any of the management activities presented here provided a vector for colonization in this Colorado Plateau landscape. They conclude this chapter by suggesting that managers continue to monitor these permanent plots so to adequately document whether the trends that the authors found will continue over time, or will differ as time from disturbance passes.

The response of Colorado Plateau vegetation communities to fire is further explored in Chapter 16, where the 2000 Outlet fire in Grand Canyon National Park is examined. In this chapter, Julie Crawford brings to light the need to investigate high severity fire and the effects of fire-fighting activity on vegetation and understory recovery in mixed conifer forests. The Outlet Fire burned over 13,000 
acres $(5,261$ ha) of mostly mixed conifer forest on the North Rim of Grand Canyon National Park and Kaibab National Forest. This chapter documents a study that examined post-fire vegetation change in relation to three types of disturbance: 1) high severity burned areas, 2) fire-fighting staging areas, and 3) fire-fighting handlines. Crawford employed an Indicator Species Analysis, Nonmetric Multidimensional Scaling, and ANOSIM to determine indicator species and trends among disturbance types and across years. She found statistically significant differences in floristic composition, cover, and diversity over time and among disturbance types. Burned sites had the highest vegetation cover in the first and subsequent years through 2004. Diversity in the burned areas decreased following dieback of the initial invasion and by 2004 became largely floristically homogeneous with high cover of two native rhizomatous species. Few exotic species were present in high severity burn transects, although by 2004 , Bromus tectorum L. (cheatgrass) had become an indicator species. Staging areas used in fire-fighting contained the greatest number of exotic species in all years of study, but this may be related to continued use of these roadside areas by Park visitors. Areas of handlines showed no statistically significant differences between 2000 and 2004, indicating no vegetation recovery had occurred.

Several studies have found that the damage associated with fire control activities is a concern and should be properly examined (see also the previous chapter 15). Crawford found that following handline construction, the current methods of site rehabilitation do not improve vegetation recovery. In addition, she feels that managers should: 1) require mitigation for fire fighters and their equipment to eliminate the spread of exotic plants, 2) continue and expand this study to investigate vegetation response at additional sites of fire and fire-fighting activity, 3) conduct experiments on the effectiveness and efficiency of restorative seeding using locally collected native species, and 4) encourage the local collection and storage of native seed for post-disturbance management. The author also felt that continued monitoring is essential for understanding long-term changes of vegetation to high-intensity fires and fire-suppression crews in high-elevation forests on the Colorado Plateau.

Chapter 17 by Crall et al. evaluated relationships between native and non-native plant species richness and cover within and across 15 vegetation types in the Grand Staircase-Escalante National Monument, Utah. This chapter extends the vegetation portion of this book into the Colorado Plateau region of southern Utah, focusing on a Bureau of Land Management (BLM) area. The authors spend time discussing how various theories have been proposed to explain patterns of species richness using measures of productivity, with the most widely accepted theory suggesting that this relationship results in a hump-shaped / unimodal curve, with species richness increasing and then decreasing as productivity increases (e.g., Grime 1973a, 1979, Huston 1979, Tilman 1982, Rosenzweig 1992, Huston 1994, Grace 1999). However, some authors have suggested that surveys of species richness conducted over limited productivity ranges are less likely to detect a hump-shaped relationship than are studies conducted over a broad productivity range (Begon et al. 1990, Rosenzweig 1992, 1995, Huston 1994, Grace 1999). Therefore, data are clearly lacking to establish only one relationship between native species richness and productivity, and the authors examine this perceived need throughout the chapter.

The authors develop four hypotheses: 1) That the common unimodal relationship between species richness and total cover would be found for native and non-native species when looking across all vegetation types, and that this relationship should only show a monotonic increase for xeric and a monotonic decrease for mesic vegetation types; 2) Native and non-native species richness and cover would be greatest in the mesic vegetation types (when compared to the xeric vegetation) because of greater resource availability; 3) Non-native species richness and cover would be positively correlated with native species richness and cover within and across vegetation types at the plot scale, but that the reverse would be found at smaller spatial scales due to competitive interactions; and, 4) Disturbance will increase non-native species richness and cover because disturbance is known to facilitate the 
establishment and potential dominance of non-native plant species. The objectives of their study were to evaluate the relationships between native and non-native plant species richness and cover in the BLM Grand Staircase-Escalante National Monument, and to provide some insight into how these relationships might be affected by productivity and disturbance across vegetation types at different spatial scales. In addition, to help guide and direct future BLM management efforts they determined where non-native species have successfully established and gained dominance within the Monument.

The authors discuss the various mechanisms that can make species-rich vegetation types (e.g., riparian vegetation communities) more easily invaded than species-poor vegetation types. Species richness tends to be low in stressful environments as a result of few species being able to survive under harsh conditions (Grime 1973a, b). If species-poor vegetation types are a result of limited resources, the authors argue that non-natives are also unlikely to establish and succeed in those areas. Stohlgren et al. $(1998,1999)$ also suggest that non-natives would more likely be found in areas of greater species richness and resource availability. Natural and anthropogenic disturbances are also correlated with the vulnerability of habitats to invasion (Fox and Fox 1986, Hobbs 1989, Hobbs and Huenneke 1992). As niche space in a vegetation type becomes available through disturbance, the establishment of a nonnative species may be possible because of open space and increased nutrient availability (Robinson et al. 1995). However, establishment of non-native species into these areas may still be limited by dispersal or seed availability (Rosentreter 1994).

To add to this complexity, it is not known which factors make a vegetation type vulnerable to plant invasion. But a long-held theory of invasion asserts that disturbed, species-poor communities are more susceptible to invasion by non-natives due to a lack of biotic resistance from such factors as competition or predation (Elton 1958, Simberloff 1986). The authors point out that all of these theories are confounded by studies being conducted at multiple spatial and temporal scales (Levine and D'Antonio 1999, Stohlgren 2002). Several multi-scale observational studies have shown both a negative and a positive relationship between native and non-native species richness at small spatial scales (Brown and Peet 2003, Fridley et al. 2004), whereas a positive relationship was seen at larger spatial scales in most cases (Stohlgren et al. 1998, 1999). This may be a consequence of differences in primary controls on diversity. At smaller spatial scales (plant neighborhoods), native and non-native species richness may be negatively correlated because of competitive exclusion, while at larger spatial scales the effects of competition might be reduced or reversed because most competitors have similar habitat requirements (Levine and D'Antonio 1999). Nevertheless, differences at multiple scales have made it difficult for researchers to develop broad generalizations related to non-native species invasions.

In addition, the authors point out that research findings are dependent on the vegetation type's stage of invasion at a particular point in time (i.e., temporal scale). Positive relationships between native and non-native species richness may occur only in the early stages of invasion, while later in the invasion process certain non-native invaders might have the capability to drastically alter an ecosystem (e.g., Vitousek et al. 1987, D'Antonio 2000). In such cases, native species richness is likely to be reduced as a result of the non-native species ability to gain dominance under these new conditions. Thus, it remains unclear as to what role productivity and disturbance may play in determining native and non-native species richness.

Crall et al. did find that, at all scales, regressions across all vegetation types showed an increase in species richness as total cover increased. They also demonstrated a monotonic increase in total cover for the xeric vegetation types, at both large and smaller scales on this BLM monument. Thus, they suggest that the hump-shape model (see Grime 1973a, 1979, Huston 1979, Tilman 1982, Rosenzweig 1992, Huston 1994, Grace 1999) may not be applicable to less productive landscapes such as the 
Monument. This may be an indication that productivity should be used in multivariate analyses, along with the other factors, in order to better explain patterns of species richness over the Colorado Plateau.

Chapter 18 concludes the group of chapters that address vegetation issues, examining techniques of ecological restoration on forest roads. Across many landscapes, and especially on the Colorado Plateau, forest roads are a common component of the environment. Nearly half of all ponderosa pine forest lies within 0.25 miles of a road. The impacts of roads and trails in forests of the Colorado Plateau are of particular concern to people who deal with ecological restoration (Covington 2003). Forest-road removal is increasingly being used as a method of restoring pre-disturbance hydrology, ecosystem processes, and habitat continuity. The physical aspects of road rehabilitation are well studied (e.g. Luce 1997), but little research has been done to assess the effectiveness of these procedures in restoring critical ecosystem attributes and processes. When forest roads are constructed, the organic soil layers are removed, leaving a surface that is primarily mineral soil which lacks symbiotic and other fungi that assist with essential processes in the soil food web, such as nutrient cycling and plant community support (Harvey et al. 1979).

The purpose of the study by Joseph Trudeau was to examine one possible method for increasing the effectiveness of road restoration through the utilization of fungal inoculum that would assist plant and microbial communities to achieve pre-disturbance conditions. He investigated the effects on plant establishment using ground waste-wood (mulch) and fungal inoculum, and then evaluated the effectiveness of inoculated saprophytic fungi in colonizing ponderosa pine mulch. This experiment was conducted on areas that had formerly been forest roads, with three experimental roads selected at Northern Arizona University's Centennial Forest near Flagstaff, Arizona. Each road was divided into five experimental blocks containing four identical treatments. Treatments were 1) control, 2) mycorrhizal inoculum, 3) mulch, saprophytic fungal inoculum, and mycorrhizal inoculum, and 4) mulch only. All plots were seeded with the same mix of native plants. Trudeau collected data at two and 14 months after application of treatments, and found that mycorrhizal inoculum had no effect on grass seedling establishment, species richness, or abundance, while mulch was found to significantly suppress plant establishment. The author also found that mulched plots had lower species richness and abundance. However, he did discover that Gambel oak seedlings were more frequent on mulched plots but not commonly found on non-mulched plots. Saprophytic inoculum showed poor survivorship; after 14 months, only $34 \%$ of the inoculated sites were colonized, while most mulched plots were naturally colonized by resident soil fungi. Trudeau concludes this chapter by suggesting that inoculation is less effective than natural colonization, and that until sources of inoculum that are adapted to local conditions are developed, the methods that he examined are less effective than natural revegetation processes.

\section{Gaining Insights From the Past}

The final two chapters of this book focus on research that provides managers with insights from the past. In Chapter 19, Cole et al. provide readers with a compelling argument that climate change will have a dramatic effect on plant species distributions over the Colorado Plateau. They describe new techniques for paleobotany modeling, using the widespread southwestern tree species, Colorado Pinyon pine (Pinus edulis). Their model requires knowledge of the plant's current distribution, climate tolerances, migratory response to change, and the geography of future climates, and incorporates all of the climate-modulated physical and biological variables occurring near the continental range of the species during the Twentieth Century. The authors then developed models of future potential geographic ranges by applying this climatic envelope to future climate predictions from General Circulation Model (GCM) results. Finally, in order to distinguish between this future potential climate range and the 
species' likely future range, they apply a spatial model of the species observed migration rate in response to past and ongoing climate warming. Through the compilation of spatially detailed data for the Twentieth Century climate model, the GCM modeling, and present pinyon distribution data, their results are projected to a landscape grid scale of $\sim 1 \mathrm{~km} 2$.

The modeling results of Cole et al. for pinyon pine suggest that over the next 100 years, the range of pinyon pine will continue to profoundly contract throughout Arizona, Utah, and southern New Mexico, but will expand in Colorado and northernmost New Mexico. The results from this one GCM scenario imply a large magnitude of change for this species, and delineate useful areas in which managers can focus future monitoring efforts. This detailed projection allows the application of their results to be easily used by individual land managers as well as providing specific predictions of future distributions that would assist land-management agencies with future monitoring efforts.

In the final chapter of the book, Draut and Rubin examine the role of wind-blown (aeolian) sediment on the preservation of archaeological sites along the Colorado River corridor in Grand Canyon National Park. They document that aeolian deposits in the river corridor fall broadly into two categories: 1) Modern Fluvial Sourced (MFS) deposits, which form as the wind transports sand inland from $<1,270$ $\mathrm{m}^{3} / \mathrm{s}\left(45,000 \mathrm{ft}^{3} / \mathrm{s}\right)$-stage sandbars, creating aeolian dunes directly downwind, and 2) Relict Fluvial Sourced (RFS) deposits, which formed as wind eroded and redistributed sediment of extensive pre-dam fluvial terraces. Archaeological material is known to occur in aeolian deposits of both types. The authors then describe how Glen Canyon Dam operations have caused a reduction in sandbar size, thereby reducing the supply of sand available for transport from upwind sources to provide cover to some archaeological sites. They also show how past and present sedimentary processes can be evaluated, along with modern wind and sand-transport rates, to assess the sensitivity of specific areas and associated cultural sites along the Colorado River corridor in the Grand Canyon, to dam operations.

The authors found that some archaeological sites in Modern Fluvial Sourced dunes have been negatively affected by loss of aeolian sand caused by decreased sand supply on upwind sandbars, a process attributable to dam operations. They suggest that these sites could benefit from aeolian redistribution of new sand deposited on fluvial sandbars by sediment-rich controlled floods. The November 2004 Colorado River high flow resulted in major deposition of new sand in many areas that are sediment sources for Modern Fluvial Sourced aeolian deposits, and that wind reworking of 2004 flood sand has also been observed to fill in small eroded gullies. The authors document that three months of high daily flow fluctuations in 2004 removed much of the new sand prior to the start of the first post-flood windy season in April 2005. Draut and Rubin conclude their chapter by suggesting that the restoration potential for cultural sites in aeolian deposits can be maximized by using dam operations (controlled floods and post-flood flows) that maximize the exposed sand area on fluvial sandbars from April through early June, when wind-borne sediment transport is greatest in Grand Canyon.

\section{Summary}

The 20 chapters of this book have brought together much of the current research on the Colorado Plateau, particularly that which is applicable to land managers. More and more we see people from diverse backgrounds coming together on the Colorado Plateau to achieve common conservation goals. The beginning portion of the book provides examples of collaborative processes that have worked. These chapters also provide recipes of what 'ingredients' are necessary to assure fruitful collaborations. If the public and private land stewards in Arizona, Utah, Colorado, and New Mexico, and in particular managers of our National Parks, U.S. Forest Service, Fish and Wildlife Service, Bureau of Reclamation, tribal lands, and the many new BLM National Monuments, utilize the ideas and concepts presented within this portion of the book, they will be better able to launch efforts toward enhanced management 
and stewardship of their lands. Along with the collaborative tools, these groups will also find useful some of the large-scale land-use tools that are presented in the second section of the book. The GAP and ReGAP programs have now reached a level of development that makes them powerful tools to address large-scale questions and issues over the Colorado Plateau.

The chapters on assessing wildlife and vegetation issues, like many of the chapters in this series' previous books, provide species- and location-specific information that managers can use to better preserve their wildlife and vegetation resources. From looking at the history and movement patterns of pronghorn, and responses of that species to fenced transportation corridors, to relocation of bighorn sheep, wildlife managers have new information and tools that will better enable them to properly manage wildlife. Those land managers that have concerns with the monitoring and preservation of birds, will find current information on monitoring and responses of avian communities to forest management. In particular, the power analysis provided by Spence in chapter 9 should serve as an example that similar studies may use in the analyses of their monitoring information. For the first time, the Colorado Plateau manager is supplied with a complete inventory of all herpetofauna that they should expect to occur on their managed lands. There is also valuable information provided on the potential impacts of fire on native trout populations. The scientist and manager are also provided with an insight into potential cave invertebrate resources over the Colorado Plateau.

As in previous books of this Colorado Plateau series, a number of chapters examine the impact of fire on vegetation communities. This is the first time that fire and restoration ecology are examined together in the same context, within the ponderosa pine ecosystem. Finally, there are sections of this book that provide the reader who is interested in natural and cultural resources, with a glimpse into the past and some predictions about the future state of the Colorado Plateau. It truly is our hope that the material in this volume will provide land managers with useful information and tools, and that this information can in some way act as a stimulus of future research support for cultural, natural, and physical resources over the Colorado Plateau.

\section{Abstracts}

CREATING SUCCESSFUL COLLABORATIONS IN THE WEST: LESSONS FROM THE FIELD Whitney Tilt, Craig Conley, Michele James, Janet Lynn, Tischa Muñoz-Erickson, and Peter Warren

Two women approach one another on Main Street in a rural western town. On becoming aware of the other's presence, they cross to opposite sides of the street. Though of similar age and interests, each avoids the other because of their perceived differences, one supports timber cutting and believes the local timber industry's long tenure to be a central pillar in the community. The other woman is a relative newcomer whose anti-timber-harvest stance and other "outsider" views are equally strongly held and defended. In a town suffering economic depression, each woman views the other as the cause of her distress. The town could be any one of the hundreds throughout the West where a richness of natural resources first attracted miners, loggers, and ranchers. More recently, such towns have attracted a growing immigration of newcomers whose livelihoods and sensitivities are often tied to economies and cultures outside the region. Amid traditional concerns about economic survival and resource utilization arises a growing concern with resource preservation. With these differences comes conflict.

THE FRAME PROJECT -A COLLABORATIVE MODELING APPROACH TO NATURAL RESOURCE MANAGEMENT AT MESA VERDE NATIONAL PARK, COLORADO Christine E. Turner, William H. Romme, Jim Chew, Mark E. Miller, George Leavesley, Lisa FloydHanna, George San Miguel, Neil Cobb, Richard Zirbes, Roland Viger, and Kirsten Ironside 
The rapid pace of social and environmental changes over the past few decades has presented significant challenges for the people who manage our public lands. Demographic shifts have placed large populations in close proximity to public lands and have resulted in increased public scrutiny of decision making on those lands. Natural resource managers are required to make informed decisions about multiple resources in complex natural systems in the face of competing and often conflicting objectives and values. The result is that natural resource managers are managing not only resources but also public expectations in the evolving nature of resource management (Tony Cheng, personal communication 2005). The challenge for today's natural resource manager is thus to optimize the management of multiple resources while minimizing the negative impacts of any given decision, and, at the same time, to engender trust and acceptance of the decision process. No small task.

In response to the increased expectations, two trends in natural resource management have emerged: a trend toward engaging stakeholders in participatory, collaborative processes, and a trend toward wider use of modeling to help manage the inherent complexity of natural systems. Collaborative engagement of stakeholders results in more inclusive and transparent decision making, which can engender greater acceptance of decisions and a wider sense of stewardship (Wondolleck and Yaffee 2000). The trend toward the use of numerical modeling in resource management addresses the need to accommodate the numerous and complex interactions of natural systems (Jakeman et al. 2006).

To adequately represent the inherent complexities of natural systems we need a way to fully address the interactions and feedback among individual components of the system. Although a large number of individual models are available to address individual components of natural systems, the coupling of these models is missing. The USGS's Modular Modeling System (MMS; http://www.brr.cr.usgs.gov/mms) offers an ideal framework to facilitate the integration and linking of process models and the execution of them in a coupled manner. The framework also facilitates adaptive management approaches where alternative scenarios and model combinations can be applied and refined iteratively with new scientific understanding and observations from monitoring results.

The principles of collaboration are helpful in situations in which knowledge is distributed among different parties. Although collaborative approaches to natural resource management often involve participation by the public and stakeholder groups (Wondolleck and Yaffee 2000), our collaborative process centers on a smaller set of participants - namely, resource managers, scientists, and modelers.

CONSERVATION STATUS OF THE COLORADO PLATEAU USING SOUTHWEST REGIONAL GAP ANALYSIS STEWARDSHIP DATA

Andrea E. Ernst and Julie S. Prior-Magee

The Colorado Plateau, as defined by the Nature Conservancy's (2005) Terrestrial Global Assessment Units, Ecoregions and Major Habitat Types, is perhaps one of the most biologically diverse ecoregions in North America. The conservation of such biodiversity is considered vitally important for the preservation of naturally functioning ecosystems (Ricketts et al. 1999). The Colorado Plateau ecoregion covers more than 196,500 km2 across southeastern Utah, northern Arizona, northwestern New Mexico, and western Colorado. Unique geological formations and processes characterize this ecoregion, which is one of the most remote and unspoiled landscapes of the desert Southwest (Nie 1999; Tuhy et al. 2002). Its relative isolation, complex geology, and specialized landform features contribute to a highly diverse endemic flora and fauna, with approximately 290 species that are found nowhere else in the world (Kartesz and Farstad 1999).

The conservation of natural resources was brought to national attention in the late nineteenth century (Sellars 1997; Anderson 2000) as the result of concerted literary, scientific, and bureaucratic campaigns. Legislation was first introduced in 1882 to formally protect and preserve a portion of the 
Colorado Plateau under federal jurisdiction by setting aside the Grand Canyon as a public park (Anderson 2000). Then after a decade of failed attempts the Grand Canyon Forest Reserve was established, but grazing, mining, and logging were still permitted. The establishment of the Grand Canyon National Monument in 1906 served to further limit development within the monument boundaries (Anderson 2000), and over time other national forests, parks, and monuments have been established (BLM 2000) that also provide areas specifically intended to preserve the region's natural and cultural diversity.

The Colorado Plateau is considered to be a remnant of the American frontier, with its extensive undeveloped landscapes and generally rural populations. Although it is mostly characterized by vast open spaces and a relative degree of isolation, there are signs of human alterations on more than 85 percent of the landscape (Ricketts et al. 1999; Tuhy et al. 2002); this includes dammed rivers and tributaries, suppression of natural fire patterns, and the invasion of exotic species. Improper grazing practices, mineral exploration and extraction, and the seasonal influx of tourists and recreationalists have also contributed to the loss and degradation of natural habitat.

One widely accepted strategy to help conserve biodiversity is to document the distribution of biologically rich areas, evaluate current levels of protection, and identify areas that may be in need of more adequate protection, with the goal of protecting representative samples of all major ecosystems with their full array of habitats and community dynamics (Noss 1992). The National Gap Analysis Program (GAP) addresses this need by creating digital maps that provide a visual representation of existing protected areas and of whatever elements of biodiversity may be present in the conservation network (Crist and Scott 1999).

\section{A GAP ANALYSIS OF ECOLOGICAL SYSTEMS OF THE COLORADO PLATEAU ECOREGION USING SOUTHWEST REGIONAL GAP ANALYSIS LAND COVER}

\section{Lisa A. Langs, Kathryn A. Thomas, John H. Lowry, and Keith A. Schulz}

Faced with competing and sometimes conflicting demands on our limited natural resources, managing for biodiversity is a significant challenge. The U.S. Geological Survey's Gap Analysis Program (GAP) takes a quantitative geographic approach to evaluating the representation of biota (i.e., vegetation and vertebrate species) in the context of current land management. Gap analysis determines the representation of biota in four biodiversity management status categories (Scott et al. 1993). Four primary GAP products are developed as inputs to the gap analysis: a land cover map showing ecological, disturbed, and land use categories, predicted habitat maps of vertebrate species, a land stewardship map that identifies land ownership boundaries, and a map of the GAP biodiversity management status categories associated with the land stewardship data. A fundamental assumption underlying gap analysis is that GAP biodiversity management status categories 1 and 2 provide adequate protection for maintaining the long-term viability of vegetation and vertebrate species occurring on those lands (Gap Analysis Program 2000).

The Southwest Regional Gap Analysis Project (SWReGAP) was a cooperative multiinstitutional effort that included the states of Arizona, Colorado, Nevada, New Mexico, and Utah; this was the first regional gap analysis project (Prior-Magee et al. 2006). Activities were coordinated with institutions from each of the five states. Utah State University coordinated land cover mapping efforts and New Mexico State University coordinated animal habitat modeling and stewardship mapping (see Boykin et al., this volume). Other participating institutions included the USGS Southwest Biological Science Center in Flagstaff, Arizona; the U.S. Environmental Protection Agency, Landscape Ecology Branch, in Las Vegas, Nevada; the Colorado Division of Wildlife in Denver; and Colorado State University in Fort Collins. NatureServe ecologists supported the land cover mapping effort by 
developing a regional scale classification system of ecological systems to describe natural vegetation cover as part of the land cover legend and to ensure regionally consistent application of ecological system concepts.

Vegetation at the plant community or association and alliance levels, as described by the U.S. National Vegetation Classification System (USNVCS; Federal Geographic Data Committee 1997), is inherently difficult to map at regional scales. NatureServe addressed this problem by developing a new classification system - the Terrestrial Ecological Systems Classification framework for the coterminous United States (Comer et al. 2003). Ecological systems are groups of plant communities and sparsely vegetated habitats unified by similar ecological processes, substrates, and/or environmental gradients (Comer et al. 2003); these are linked to the USNVCS through characteristic associations and alliances.

\section{A GAP ANALYSIS OF TERRESTRIAL VERTEBRATE SPECIES OF THE COLORADO} PLATEAU: ASSESSMENT FROM THE SOUTHWEST REGIONAL GAP ANALYSIS PROJECT Kenneth G. Boykin, Charles Drost, and J. Judson Wynne

As part of the Southwest Regional Gap Analysis Project (GAP), we developed spatial habitat models of 819 vertebrate species for the region comprising Arizona, New Mexico, Colorado, Utah, and Nevada. Here we apply the results of the vertebrate habitat models to the Colorado Plateau region of northern Arizona, northwestern New Mexico, southwestern Colorado, and southern and eastern Utah. The Colorado Plateau boundaries encompass habitat for 581 vertebrate species from the original mapping effort. Total species richness is highest in areas of the Colorado and San Juan River drainages. We show, however, that patterns of richness vary among different vertebrate groups and subgroups (e.g. amphibians and bats). One important use of GAP data is to evaluate what proportion of the habitat of various species is managed for long-term conservation. These data can be expressed as "threshold" levels of species protection. We compare and contrast these GAP threshold species with lists developed by the state wildlife agencies of the southwestern states for "species of greatest conservation need" (SGCN). Our threshold lists differ from the SGCN lists because of their focus on longer-term protection of species that may still be quite common. In this way, the Southwest GAP data offer an alternative for land management and conservation planning in the region.

Conservation planning and assessments over large regions provide the ecological context necessary for landscape-scale management decisions. Previous conservation assessments have been conducted for the Colorado Plateau (Tuhy et al. 2002) and portions of the plateau in Arizona (Arizona Game and Fish Department 2005a, 2005b), Colorado (Colorado Division of Wildlife 2005), New Mexico (New Mexico Department of Game and Fish 2005), and Utah (Utah Division of Wildlife Resources 2005). In addition, previous gap analysis projects have provided conservation information for the same area (Edwards et al. 1995; Thompson et al. 1996; Schrupp et al. 2001; Halvorson et al. 2002).

Gap analysis involves creating digital data sets of land cover, habitat models for terrestrial vertebrate species, and land stewardship, and analyzing the co-occurrence of these features on the landscape (See Ernst and Prior-Magee, this volume). Geographic Information System (GIS) maps and tables of these data sets allow for a wide variety of analyses for use in conservation planning. Over broad landscape scales, gap analysis provides a "coarse filter" approach to natural resources data and conservation assessments.

\section{A HISTORICAL ASSESSMENT OF PRONGHORN MANAGEMENT ON ANDERSON MESA: MISCALCULATIONS AND REMEDIES}

David E. Brown 
No area in Arizona is more associated with pronghorn than Anderson Mesa in Game Management Unit 5. More than a fourth of all of the pronghorn in the "Millennium" edition of the Arizona Wildlife Trophy Book came from this unit or from areas restocked with animals from Anderson Mesa (Lewis 2000). Three of the top five pronghorn trophies in the Boone and Crockett Club's North American Record Book are from Coconino County, where Anderson Mesa is located (Byers and Bettas 1999). Anderson Mesa was the site of Arizona's first legal pronghorn hunt after statehood, and this stony plateau has been a focal point for pronghorn studies since the early 1930s when the Coconino National Forest estimated the population to be between 4000 and 5000 head (Nichol 1931; Knipe 1944a; Edwards 1950). Pronghorn studies on Anderson Mesa have ranged from developing survey and capture methodologies (Wilkins and Welles 1944; Edwards 1947; Wallmo 1951), determining seasonal food habits (Wallmo 1951; Gay 1984), and evaluating reproductive performance (Erling 1956a; 1956b), to evaluating the effects of coyote control and other factors on fawn recruitment (Arrington 1947; Arrington and Edwards 1951; Neff and Woolsey 1979, 1980; Neff et al. 1985).

Declines in pronghorn recruitment rates and population size in the 1970s resulted in an intensive study to determine if aerial gunning of coyotes could improve the pronghorn population on Anderson Mesa. Although aerial gunning was expensive and politically unpopular, these studies indicated that pronghorn fawn recruitment could be improved by applying such control practices (Neff and Woolsey 1979, 1980; Neff et al. 1985). When pronghorn recruitment and population numbers again declined in the 1990s, however, coyote reduction efforts were no longer deemed an effective solution, initiating a demand to determine the reasons why pronghorn recruitment on Anderson Mesa was chronically below herd maintenance levels (Yoakum 2003).

\section{EFFECTS OF FENCED TRANSPORTATION CORRIDORS ON PRONGHORN MOVEMENTS AT PETRIFIED FOREST NATIONAL PARK, ARIZONA}

Jan V. Hart, Charles van Riper III, David J. Mattson, and Terence R. Arundel

Pronghorn (Antilocapra americana) are a species of concern over most of the open landscapes of western North America that they inhabit (O'Gara and Yoakum 2004). Preferred habitats for pronghorn are grasslands and shrubland-steppes, and their current range includes a large portion of the western United States, a much smaller area of adjacent southern Canada, and some isolated parts of northern Mexico. Although once present in far greater numbers than occur today, pronghorn have rebounded from near extirpation since the beginning of the twentieth century (O'Gara and Yoakum 2004). Several factors contributed to the precipitous decline in pronghorn populations, but beginning with the arrival of Europeans the chief driver was over-hunting. Protection for pronghorn, in the form of hunting bans of limited effectiveness, began as early as 1883 , but their numbers continued to decline until about 1920 (O'Gara and Yoakum 2004). During the following decade, numerous pronghorn refuges were established, though most were closed to hunting but not livestock grazing. In some areas large-scale predator control, mostly of coyotes, was also undertaken, and this too may have helped pronghorn recovery (O’Gara and Yoakum 2004).

Even before over-hunting began to result in pronghorn declines, other factors had emerged that would largely govern the fate of this animal throughout the remainder of the twentieth century and on to the present. Beginning in the mid-1800s, domestic livestock were being introduced into much of the semi-arid rangeland of the West. With the coming of the railroads during the $1880 \mathrm{~s}$, large cattle herds were soon encroaching upon and displacing pronghorn from their native ranges. The cattle were followed by sheep, which totaled as many as 40 million during the 1890s in the western United States (Wagner 1978), and these competed directly with pronghorn for forage. Although competition for resources with livestock in the late 1800s likely had adverse effects on pronghorn, perhaps the greatest 
detriment to their survival was the fencing of pasture and rangeland designed to restrict livestock movement (Brown 1994).

Fences, especially the woven fences that were used to restrict sheep, form impassable barriers to pronghorn, and greatly restrict seasonal movements. Pronghorn evolved on the open plains where speed was important for predator avoidance, but jumping ability was of little value. Consequently, although some animals have demonstrated the ability to jump effectively over fences, most pronghorn seldom do. Instead, pronghorn may travel many "miles" along a fence line searching for a gap within the fence or a space between the fence and ground that is large enough to crawl under. Where fence lines are impervious, pronghorn can become trapped, suffering mortality from lack of suitable forage or the effects of weather (Spillett et al. 1967).

\section{RELATIONSHIP BETWEEN MEASURED HABITAT QUALITY AND FIRST AND SECOND YEAR SURVIVAL FOR TRANSPLANTED BIGHORN SHEEP IN ARIZONA}

\section{Brian F. Wakeling and Erin Riddering}

Translocation programs have been largely responsible for the reestablishment of bighorn sheep (Ovis canadensis) populations throughout Arizona (Cunningham et al. 1989). Since the inception of the translocation program, Arizona's bighorn sheep population has increased from an estimated 1500 animals in 1960 to about 6000 animals in 2003 (Wakeling 2003). Bighorn sheep translocations have occurred throughout Arizona, primarily following evaluations of potential habitat using systematic evaluation criteria that allow managers to rank and prioritize habitats based on measured suitability. Many appraisals have been conducted to determine how well a variety of systematic habitat evaluations function in predicting bighorn sheep habitat use and many provide functional expectations for predicting suitable habitat (e.g., Cunningham 1989; Wakeling and Miller 1990).

Recently, mountain lion (Puma concolor) predation on transplanted bighorn sheep has been suggested to be the cause for declining bighorn sheep survival in Arizona (Kamler et al. 2002). Kamler et al. (2002) concluded that increased predation by mountain lions on bighorn sheep in more recent translocated populations was directly influenced by increasing mountain lion abundance and distribution within Arizona. An alternate hypothesis that was not explored by Kamler et al. (2002) was that more recent bighorn sheep transplants occurred in habitats with lower habitat suitability scores, which may affect predation rate by mountain lions or overall bighorn sheep survival because these habitats may be less suitable for bighorn sheep occupation.

\section{MONITORING THE RIPARIAN BREEDING BIRD COMMUNITY ALONG THE COLORADO RIVER IN THE GREATER GRAND CANYON REGION: STATISTICAL POWER AND IMPLICATIONS FOR LONG-TERM MONITORING}

John R. Spence

Avian communities along the Colorado River have changed substantially since the completion of Glen Canyon Dam in 1963 (Carothers and Brown 1991). Pre-dam vegetation along the river consisted of a thin riparian strip controlled primarily by spring flooding. Following completion of the dam, the largest tracts of riparian vegetation (in Glen Canyon) were destroyed, while an extensive "new high water zone" (NHWZ) community developed downstream of the dam through the Grand Canyon. In addition, extensive stands of riparian habitat have become established on silt terraces where the Colorado River drains into Lake Mead. These recent habitat modifications have caused changes in the avian community (Brown et al. 1987; Carothers and Brown 1991).

Because of concerns over loss of sediment, declines in native fish species, and erosion of archeological sites, the Grand Canyon Protection Act was passed in 1992. This Act specified that an 
environmental impact analysis (EIS) was to be conducted on the effects of Glen Canyon Dam operations on resources along the Colorado River in Glen Canyon National Recreation Area and Grand Canyon National Park. In 1995, the EIS was completed, and the Record of Decision (ROD) on the revised operations of Glen Canyon Dam was signed. Among other things, the ROD established a longterm science program to monitor the effects of dam operations on biological, cultural, and physical resources along the Colorado River from the dam to the head of Lake Mead, a distance of $410 \mathrm{~km}$. This monitoring program was established to provide the necessary data to adaptively manage dam operations in order to minimize impacts to selected resources (National Research Council 1999).

Various monitoring programs had been established as part of the environmental impact studies since 1982, under management of the Glen Canyon Environmental Studies Program (GCES; National Research Council 1987, 1996). These monitoring and baseline data, including studies on the avifauna, were used to develop management alternatives. In 1996 the Grand Canyon Monitoring and Research Center was established to oversee scientific monitoring of the resources as laid out in the ROD and to develop long-term monitoring and research strategic plans. Birds, principally riparian breeding birds, bald eagle (Haliaeetus leucocephalus), and the endangered southwestern willow flycatcher (Empidonax traillii extimus), have been an integral part of past and ongoing monitoring studies along the river corridor.

Birds are an important and conspicuous component of the lacustrine and riparian ecosystems along the Colorado River and on Lake Powell and Lake Mead.

\section{AVIAN COMMUNITY RESPONSES TO FOREST THINNING AND PRESCRIBED SURFACE FIRE, ALONE AND IN COMBINATION}

Sarah Hurteau, Brett G. Dickson, Thomas D. Sisk, and William M. Block

The U.S. Forest Service and other federal agencies treated more than 2.8 million ha of forested land between 2001 and 2003 under the Healthy Forest Restoration Act (USDA Forest Service 2004). Because many more areas across our landscape are slated for fuel reduction treatments, understanding how wildlife communities will respond is essential to conserving biodiversity, yet little is understood about the ecological consequences of such treatments. Prior to Euro-American settlement in the late 1800 s, ponderosa pine-dominated forests of the Southwest were characterized by open stands with a dense herbaceous understory (Stone et al. 1999). Low-intensity surface fires, with return intervals of 2 12 years on average, maintained this stand structure (Covington and Moore 1994). However, fire suppression, livestock grazing, and selective logging of old fire-resistant trees have significantly altered forest structure (Harrington and Sackett 1988; Covington et al. 1997; Stone et al. 1999; Youngblood et al. 2004). Today's forests typically are characterized by dense, closed-canopy forests (Cooper 1960; Covington and Moore 1994), leaving them susceptible to stand-replacing fires, pathogen and pest outbreaks, and nonnative species invasions (Fulé et al. 2002; Bock and Block 2005). In the Southwest, fuel reduction treatments employ mechanical thinning and prescribed surface fire to mitigate excessive fuel accumulations and, in some cases, to re-create forest structural characteristics that existed prior to the regular interruption of natural disturbance regimes (Meyer et al. 2001). However, the broader ecological effects of these techniques are not well studied.

Much of the research on the effects of fuel reduction and restoration treatments has been focused on one dominant tree species (ponderosa pine, Pinus ponderosa) and the response of understory vegetation after thinning and/or prescribed fire (Harrington and Sackett 1988; Covington et al. 1997; Stone et al. 1999; Franklin et al. 2002; Fulé et al. 2002). Research conducted to determine the effects of these treatments on wildlife has consisted largely of observational studies, generally addressing a single treatment alternative (e.g., King and DeGraaf 2000; Saab et al. 2004) or focusing on a single species 
(e.g., Germaine and Germaine 2002), and not the response of the avian community as a whole. Although literature reviews have been conducted to identify how avian communities respond to mechanical thinning, wildfire, and post-fire salvage logging (e.g., Kotliar et al. 2002; Saab and Powell 2005), no study has experimentally tested the effects of multiple fuel reduction treatment types on avian communities.

Our research was conducted on the Fire and Fire Surrogates (FFS) program Southwest Plateau sites (Edminster et al. 2000). The national FFS program is an integrated network of 13 long-term research sites designed to quantify the effects of prescribed fire and mechanical thinning on a set of ecosystem health response variables, including wildlife.

\section{OVERVIEW OF HERPETOFAUNA INVENTORIES IN SOUTHERN COLORADO PLATEAU NATIONAL PARKS}

Trevor B. Persons, Erika M. Nowak, and David G. Mikesic

In 2000, the National Park Service (NPS) initiated a nationwide program to inventory vertebrates and vascular plants within the national parks. As part of this inventory effort, 265 National Park units (parks, monuments, recreation areas, historic sites) were identified as having significant natural resources, and these were divided into 32 groups or "networks" based on geographical proximity and similar habitat types. The many NPS areas on the Colorado Plateau of Utah, northern Arizona, northwestern New Mexico, and western Colorado were divided into northern and southern Colorado Plateau networks. Here we summarize the results of amphibian and reptile (herpetofauna) inventories at the 19 parks in the Southern Colorado Plateau Inventory \& Monitoring Network (SCPN) and synthesize distribution and habitat information for all amphibian and reptile species across that network. The primary goal of these complete species inventories was to document 90 percent of the species present at each park. To evaluate our progress toward that goal we estimated our level of inventory completeness for each park at the end of the project. We also discuss considerations for future inventory work.

\section{PERSISTENCE OF APACHE TROUT FOLLOWING WILDFIRES IN THE WHITE MOUNTAINS OF ARIZONA Jonathan Long}

Wildfires are a natural disturbance that can rejuvenate and rebuild trout habitat by stimulating flood scour and deposition (Gresswell 1999; Bisson et al. 2003). However, several case studies from Arizona and New Mexico have shown severe reductions in fish populations shortly after wildfires (Neary et al. 2005). The consequences of wildfire are a particular concern in the mountainous watersheds that harbor Apache trout (Oncorhynchus gilae ssp. apache) and Gila trout (Oncorhynchus gilae ssp. gilae). Populations of these federally protected species are scattered among small stream reaches that are isolated by the presence of non-native trouts, intermittent flows, thermal regimes, natural barriers, and barriers to exclude non-native trout (Brown et al. 2001; Rieman et al. 2003; USFWS 2006). Wildfires have extirpated seven populations of Gila trout since 1989, impeding recovery efforts (Propst et al. 1992; USFWS 2006). Emergency evacuation of populations threatened by fire has become an important element of Gila trout recovery (Anderson 1992; USFWS 2006), and has been recommended as a "fundamental management approach" for conserving isolated populations of rare native fishes (Rinne 2004). However, because evacuation is costly and stressful to fish, managers need to know when it is necessary to prevent population losses.

CAVE-DWELLING INVERTEBRATES OF GRAND CANYON NATIONAL PARK J. Judson Wynne, Charles A. Drost, Neil S. Cobb, and John R. Rihs 
Cave ecosystems are among the most fragile ecosystems on Earth (Elliott 2000; Hamilton-Smith and Eberhard 2000) due, in part, to the sensitivity of cave-dwelling organisms to disturbance. Because many troglomorphic taxa (obligate cave-dwelling organisms) are endemic to a single cave or region (Reddell 1994; Culver et al. 2000; Christman et al. 2005), and are generally characterized by low population numbers (Mitchell 1970; Krajick 2001), many populations are considered imperiled (Reddell 1994; Culver et al. 2000). Most studies of cave invertebrates have been simple inventories, with relatively little data collected on species and community ecology.

For this study we have synthesized all known information on cave-dwelling invertebrates in Grand Canyon National Park (GRCA). There is a paucity of knowledge about caves in GRCA, as well as other areas on the southern Colorado Plateau. The available information is limited to a few intensive studies (where invertebrates were collected and identified) and cave trip reports (where invertebrates were documented visually). Here we determine the extent of knowledge concerning cave-dwelling invertebrate fauna, identify the seemingly most common cave-dwelling invertebrates, and present our preliminary understanding of invertebrate diversity and endemism in Grand Canyon caves.

\section{VEGETATION OF PETRIFIED FOREST NATIONAL PARK, ARIZONA}

\section{Kathryn A. Thomas, M. L. Hansen, and Keith A. Schulz}

Petrified Forest National Park in northeast Arizona is known for its rocks, ruins, and scenic Painted Desert vistas, but the park is equally a premier example of Colorado Plateau grasslands and steppe. The vegetation of the park has been protected from many development disturbances since 1905 and from widespread cattle grazing since 1963. The most recent description of vegetation at Petrified Forest originated as part of the National Park Service's Southern Colorado Plateau Network classification and mapping of vegetation types at the park. We describe the vegetation of the park using the results of this classification work.

A vegetation classification describes assemblages of plants and assumes that there are characteristic and repeated groupings of plant species across the environment. Vegetation classification systems are tools used to describe the patterns observed. In the last decade, there has been a national effort to establish standards and protocols for vegetation studies that will lead to consistency and comparability in describing and classifying those patterns.

In recognizing the need for a federal standard for vegetation classification and reporting of vegetation statistics, the Federal Geographic Data Committee (1997) has adopted the National Vegetation Classification Standard (NVCS) for inventory, mapping, and reporting on vegetation resources. The standard builds on earlier work on vegetation classification done by UNESCO (1973), Driscoll et al. (1984), and Grossman et al. (1998).

The NVCS describes a hierarchical classification system with the upper levels (system, class, subclass, group, subgroup, and formation) describing physiognomic characters of the vegetation and the lower levels (alliance and association) based on floristic characters of the vegetation. The initial standards (FGDC 1997) describe the upper level categories, but not the floristic levels. Identification and description of these finest levels (the alliance and association) has been derived from various mapping projects, such as the Southern Colorado Plateau Network's vegetation mapping efforts and plant community classifications by academic and government researchers.

An alliance is a "physiognomically uniform group of plant associations sharing one or more dominant or diagnostic species, which as a rule are found in the uppermost stratum of the vegetation" (Grossman et al. 1998). An association is "characterized by diagnostic species that occur in all strata (overstory and understory) of the vegetation" (FGDC 1997). Alliances and associations are also 
identified by the predominant lifeform and the vegetation structure of the assemblage they describe, and are placed hierarchically below the FGDC physiognomic levels.

\section{UNDERSTORY VEGETATION RESPONSES TO MULTI-AGED GROUP SELECTION HARVESTING AND PRESCRIBED FIRE IN NORTHERN ARIZONA}

\section{John D. Bailey and Robert K. Speer}

Ponderosa pine (Pinus ponderosa) forests in the semi-arid Southwest have become increasingly dense over the past century. Changes in land use practices brought by Euro-American settlers beginning in the late 1800s created these shifts in forest structure (Covington et al. 1994, 1997; Moore et al. 1999). The current high density of ponderosa pine forests allows little sunlight for understory vegetation (Naumburg and DeWald 1999). Extensive grazing of domestic livestock has further depleted a rich understory of grasses and forbs that once out-competed pine seedlings, and this depleted understory once drove the frequent surface fires that further prohibited extensive pine regeneration (Korb and Springer 2003). In addition to supporting a natural fire regime (Laughlin et al. 2004), healthy understory communities promoted a number of ecosystem functions including hydrology and soil stabilization (Korb and Springer 2003), net primary productivity, nutrient cycling, and forage for wildlife and domestic livestock (Harris and Covington 1983). Of particular interest in regards to harvesting, burning, and general soil disturbance is the introduction and spread of alien species (Crawford et al. 2001; Sieg et al. 2003; Korb et al. 2004). Alien species are of importance to ecosystem function and health because they alter successional pathways by out-competing native pioneer species, thereby altering ecosystem functions normally performed by native species (Fornwalt et al. 2003).

Our understory vegetation study was conducted on one of 13 sites in the national Fire and Fire Surrogate (FFS) Program, a large multi-disciplinary study that examines the effectiveness of mechanical harvesting and prescribed burning, alone and in combination, for reducing wildfire risk while improving forest health (Weatherspoon 2000). Our goal was to learn more about how perennial and annual understory plants respond to increasing intensities of management (burn only, harvest only, harvest \& burn), with a focus on species richness and native and exotic ground cover.

\section{FIVE YEARS OF VEGETATION CHANGE FOLLOWING HIGH-SEVERITY FIRE AND FIRE- FIGHTING ACTIVITIES IN GRAND CANYON NATIONAL PARK Julie Crawford}

Prior to the establishment of Grand Canyon National Park (GRCA) in 1919 and for some years thereafter, livestock grazing took place over the entire park, with the exception of concessionaire areas at Bright Angel Point on the North Rim and the Village area on the South Rim (Crosby 1923). This grazing, coupled with periods of deer overpopulation (Binkley et al. 2006) and decades of fire suppression (Fulé et al. 2002; Wolf and Mast 1998; White and Vankat 1993), has resulted in reduced herbaceous layers, fine fuels, and fire frequency. In the forest communities of the North Rim, this fire frequency reduction has led to invasions of small shade-tolerant and fire-intolerant Abies concolor (Gord. \& Glend.) Lindl. ex Hildebr. (white fir), homogeneity of forest structure, and high fuel loads. Although at least some of the North Rim forests studied by White and Vankat (1993) and Fulé et al. (2003) were characterized by naturally high-severity fire regimes, the current structure of these forests has resulted in a greater likelihood of higher severity fire at larger than historic scales. This is a serious concern for park resource managers and it has led to increased prescription burns in these forests in recent decades.

The Outlet fuel-reduction prescription fire on the North Rim, which was ignited near Outlet Canyon on 24 April 2000, burned 465 acres (188 ha). However, this prescribed fire jumped its intended 
boundary, and the National Park Service classified the burn as the Outlet wildfire on 9 May 2000. The Outlet wildfire, referred to herein as the Outlet fire, which began near Bright Angel Spring, eventually burned 8776 acres (3552 ha) in GCNP. It spread in a northeast direction to burn 5109 acres (2068 ha) of Forest Service land, and continued to burn for 36 days until it was contained on 15 June. Since the park's inception, other than the Saddle Mountain fire of 1960, fire has been suppressed throughout the area burned by the Outlet fire.

The North Rim of GRCA is diverse elevationally (roughly 6000-9200 ft, or 1829-2804 m) and topographically (slope aspect, position, and inclination), supporting a variety of vegetation communities including pinyon-juniper woodland, ponderosa pine forest, montane grassland, mixed conifer forest, and spruce-fir forest (Rasmussen 1941; Merkle 1954). Although the Outlet fire burned in portions of all of these communities, the mixed conifer forest was the dominant community altered by the fire. Study transects fell within the mixed conifer forest and montane grassland communities.

\section{NATURAL VARIATION IN DIVERSITY AND INVASION PATTERNS OF THE GRAND} STAIRCASE-ESCALANTE NATIONAL MONUMENT, UTAH

Alycia W. Crall, Thomas J. Stohlgren, Paul Evangelista, and Deb Guenther

Various theories have been proposed to explain patterns of species richness using measures of productivity (Palmer 1994; Waide et al. 1999; Mittelbach et al. 2001). A predominant theory has generalized this relationship to a hump-shaped/unimodal curve, with species richness increasing and then decreasing as productivity increases (Grime 1973a, 1979; Huston 1979; Tilman 1982; Rosenzweig 1992; Huston 1994; Grace 1999). However, some authors have suggested that surveys of species richness conducted over limited productivity ranges are less likely to detect a hump-shaped relationship than studies conducted over a broad productivity range (Begon et al. 1990; Rosenzweig 1992, 1995; Huston 1994; Grace 1999). Therefore, data are clearly lacking to establish only one relationship between native species richness and productivity.

To add to this complexity, the effects that non-native species invasions have on productivity, and consequently on native species richness, are even less understood. It is not known which factors make a vegetation type vulnerable to plant invasion. A long-held theory of invasion states that disturbed, species-poor communities are more susceptible to invasion by non-natives due to a lack of biotic resistance from such factors as competition or predation (Elton 1958; Simberloff 1986). More diverse vegetation types are also more likely to utilize available resources more completely, making it difficult for new plant species to establish (Crawley 1987; but see Stohlgren et al. 1998b). However, this theory has been challenged recently as new research has found a higher risk of invasion into highly diverse vegetation types with intermediate levels of disturbance, such as tall grass prairies, wet meadows, and riparian zones (Robinson et al. 1995; Planty-Tabacchi et al. 1996; Wiser et al. 1996; Stohlgren et al. 1999, 2001).

There are various mechanisms that can make species-rich vegetation types more susceptible to invasion than species-poor vegetation types. Species richness tends to be low in stressful environments as a result of few species being able to survive under harsh conditions (Grime 1973a, 1973b). If speciespoor vegetation types are a result of limited resources, then non-natives are also unlikely to establish and succeed in those areas and would more likely be found in areas of greater species richness and resources (Stohlgren et al. 1998b, 1999).

Natural and anthropogenic disturbances are also correlated with the vulnerability of habitats to invasion (Fox and Fox 1986; Hobbs 1989; Hobbs and Huenneke 1992). As niche space in a vegetation type becomes available through disturbance, the establishment of a non-native species may be possible because of open space and increased nutrient availability (Robinson et al. 1995). However, 
establishment of non-native species into these areas may still be limited by dispersal or seed availability (Rosentreter 1994).

\section{RESTORING ROADS IN AN ARIZONA PONDEROSA PINE FOREST: EVALUATING THE EFFICACY OF FUNGAL INOCULUM AND MULCH AMENDMENTS Joseph M. Trudeau}

In the southern Rocky Mountains area, nearly half of all ponderosa pine forest lies within 0.25 miles of a road (Southern Rockies Ecosystem Project 2000). The impacts of roads and trails in these forests are of particular concern to ecological restorationists (Covington 2003). The effects of roads on ecosystems are numerous and have been well documented. In a review of these effects, Trombulak and Frissell (2000) concluded that roads affect terrestrial and aquatic communities in the following ways: increased animal mortality from construction and vehicle collisions, modification of animal behavior, alteration of the physical and chemical environment, spread of exotic species, and increased alteration and use of natural communities by humans. In addition, roads in ponderosa pine forests can alter natural fire regimes by interrupting surface fuels and enabling recreationists to start fires in otherwise unreachable areas (Covington 2003). Friederici (2003:22) has suggested that future restoration projects in ponderosa pine ecosystems may focus on more "broad-based and holistic restoration that includes road and trail closures," but for there to be effective improvements in habitat connectivity, fuel continuity, and other measures, regionally specific information regarding techniques and methods is needed (Elseroad et al. 2003). Road removal is increasingly being used as a method for restoring predisturbance hydrology, ecosystem processes, and habitat continuity. Protocols have been established that guide the process of road ripping, which uses bulldozers to drag rock rippers or subsoilers through the road and break the compacted soil into aggregates of varying sizes. However, little research has been done to assess the effectiveness of these procedures in restoring critical ecosystem processes or attributes (Elseroad et al. 2003; Switalski et al. 2004). Luce (1997), in a study of the effects of ripping on infiltration capacity, concluded that ripping and subsoiling provide temporary and marginal improvements in hydrologic and ecological function. Elseroad (2001) confirmed these conclusions in a northern Arizona ponderosa pine forest. Ripping alone cannot be considered an effective restoration technique. The Society for Ecological Restoration (SER) considers a restored ecosystem to be one that is self-sustaining in structure and function, resilient to normal ranges of stress and disturbance, and able to interact with contiguous ecosystems (SER 2002). A road that is only ripped and then left to recover on its own may not meet these criteria within reasonable time periods. More effective procedures that restore the biological, physical, and chemical processes and properties of the disturbed soils and adjacent environment are needed in order to complement and complete holistic restoration of Southwest ponderosa pine forests.

\section{MODELING FUTURE PLANT DISTRIBUTIONS ON THE COLORADO PLATEAU: AN EXAMPLE USING PINUS EDULIS}

Kenneth L. Cole, Kirsten E. Ironside, Samantha T. Arundel, Philip Duffy, and John Shaw

The recent mortality of some plant species in the U.S. Southwest has been attributed to the ongoing drought conditions over the last decade. This mortality has been especially acute in populations of Pinus edulis (Colorado pinyon pine; hereafter abbreviated as pinyon), a widespread and highly visible species (Shaw 2006; Shaw et al. 2005; Mueller et al. 2005). These recent mortality events may be similar to changes expected to occur in the future because of global climate warming (Breshears et al. 2005). That is, the consequences of periodic episodes of low precipitation can be exacerbated by higher temperatures, which increase drought stress. Here we demonstrate new techniques for modeling the 
effect of future climates on plant species using pinyon as an example. Using the techniques described here, similar results could be generated for any plant species or for any climatically controlled environmental process.

\section{THE ROLE OF AEOLIAN SEDIMENT IN THE PRESERVATION OF ARCHAEOLOGICAL SITES} ALONG THE COLORADO RIVER IN THE GRAND CANYON

\section{Amy E. Draut and David M. Rubin}

Since the closure of Glen Canyon Dam in 1963, major changes have occurred in the natural hydrologic and sedimentary regime in the Colorado River corridor through the Grand Canyon (e.g., Andrews 1986; Webb et al. 1999; Topping et al. 2003). The dam has reduced the supply of sediment at the upstream boundary of Grand Canyon National Park (the head of Marble Canyon) by about 95 percent (Topping et al. 2000a), and the Paria River is now the only major supplier of sediment to this system. The other substantial post-dam supplier of sediment is the Little Colorado River, which enters the Colorado $98 \mathrm{~km}$ downstream from the Paria River and supplies an additional 10-15 percent of the pre-dam sediment load (Topping et al. 2000a). Operation of the dam smoothes seasonal variation in river discharge; daily discharge typically fluctuates over a much greater range than in the pre-dam state (Topping et al. 2003). Regulation of the river has important implications for the storage and redistribution of sediment. Without regular floods, the relatively small sediment load that the river carries cannot be deposited at the higher elevations in the channel that received sediment regularly before dam closure. The channel of the pre-dam river accumulated sand when discharges were below about $9000 \mathrm{cfs}$ (Topping et al. 2000a). In the absence of flows below $5000 \mathrm{cfs}$, which are not permitted under the 1996 Record of Decision signed by the Secretary of the Interior, the sediment-storage capability in the main channel is greatly reduced (Topping et al. 2000a, 2003). Most sediment supplied by tributaries below the dam is exported from the canyon on time scales of weeks to months under present flow operations (Topping et al. 2000a, 2000b; Rubin et al. 2002; Wright et al. 2005).

Numerous studies have identified the physical and biological consequences of the altered hydrograph and diminished sediment content of the Colorado River. With respect to sediment, the size and number of subaerial sand deposits have decreased systemwide over the past four decades, punctuated by episodic, localized aggradation during the 1983 flood of 97,000 cfs, the 1996 and 2004 controlled-flood experiments (45,000 and 41,000 cfs, respectively), and sediment input from occasional tributary floods (Beus et al. 1985; Schmidt and Graf 1987; Budhu and Gobin 1994; Kearsley et al. 1994; Kaplinski et al. 1995; Schmidt and Leschin 1995; Wiele et al. 1996; Hazel et al. 1999; Schmidt et al. 2004; Topping et al. 2006). Encroachment of riparian vegetation on sandbars has also contributed significantly to the loss of open sand area along the river (e.g., Turner and Karpiscak 1980).

\section{INTEGRATING RESEARCH INTO BIOLOGICAL AND CULTURAL RESOURCES MANAGEMENT ON THE COLORADO PLATEAU— A SYNTHESIS \\ Charles van Riper III}

In his book review of the Sixth Colorado Plateau Biennial Conference Proceedings: "The Colorado Plateau: Cultural, Biological and Physical Research," Fleming (2006) closes with the following statement: "A synthesis chapter by the editors on the issue of human impacts would have been a welcome addition to this potentially useful book." The following synthesis chapter provides that addition to this book, summarizing and integrating material from all previous chapters and also utilizing information from previous books published in the Colorado Plateau series. In addition to providing a synthesis, another goal of this chapter is to demonstrate how aspects of research have been used to enhance biological and cultural resource management. This book is the eighth (and the third volume 
published by the University of Arizona Press) in a series of compilations that focus on the Colorado Plateau. These books highlight the integration of research into resource management efforts, as related to cultural, natural, and physical resources within the biogeographic province. The mix of chapters addresses management issues from many diverse resources and from disparate regions of the Colorado Plateau, specifically focusing on aspects of vegetation and wildlife research, combined with a series of chapters explaining integrative and collaborative tools that can be used to better manage natural and cultural resources on smaller and larger scales.

The 20 previous chapters in this book were selected from scientific presentations at the Eighth Biennial Conference of Research on the Colorado Plateau. The conference was held 7-10 November 2005 in Flagstaff, Arizona, hosted by the U.S. Geological Survey Southwest Biological Science Center's Colorado Plateau Research Station and the Center for Sustainable Environments at Northern Arizona University. The meeting theme revolved around research, inventory, and monitoring of lands over the Colorado Plateau, with a focus on the integration of research into resources management actions. Material presented in this book represents original research that has not been previously published, and every chapter contains a section on how that research can be best implemented by managers. Each paper selected for publication has been anonymously peer reviewed by at least two scientists from that specific research discipline. These contributed scientific studies each constitute a separate chapter, with the material subdivided into sections: Collaborating to Achieve Conservation, Assessing Large-scale Land-use Issues, Addressing Wildlife Issues, Addressing Vegetation Issues, Gaining Insights from the Past, and Synthesis. 


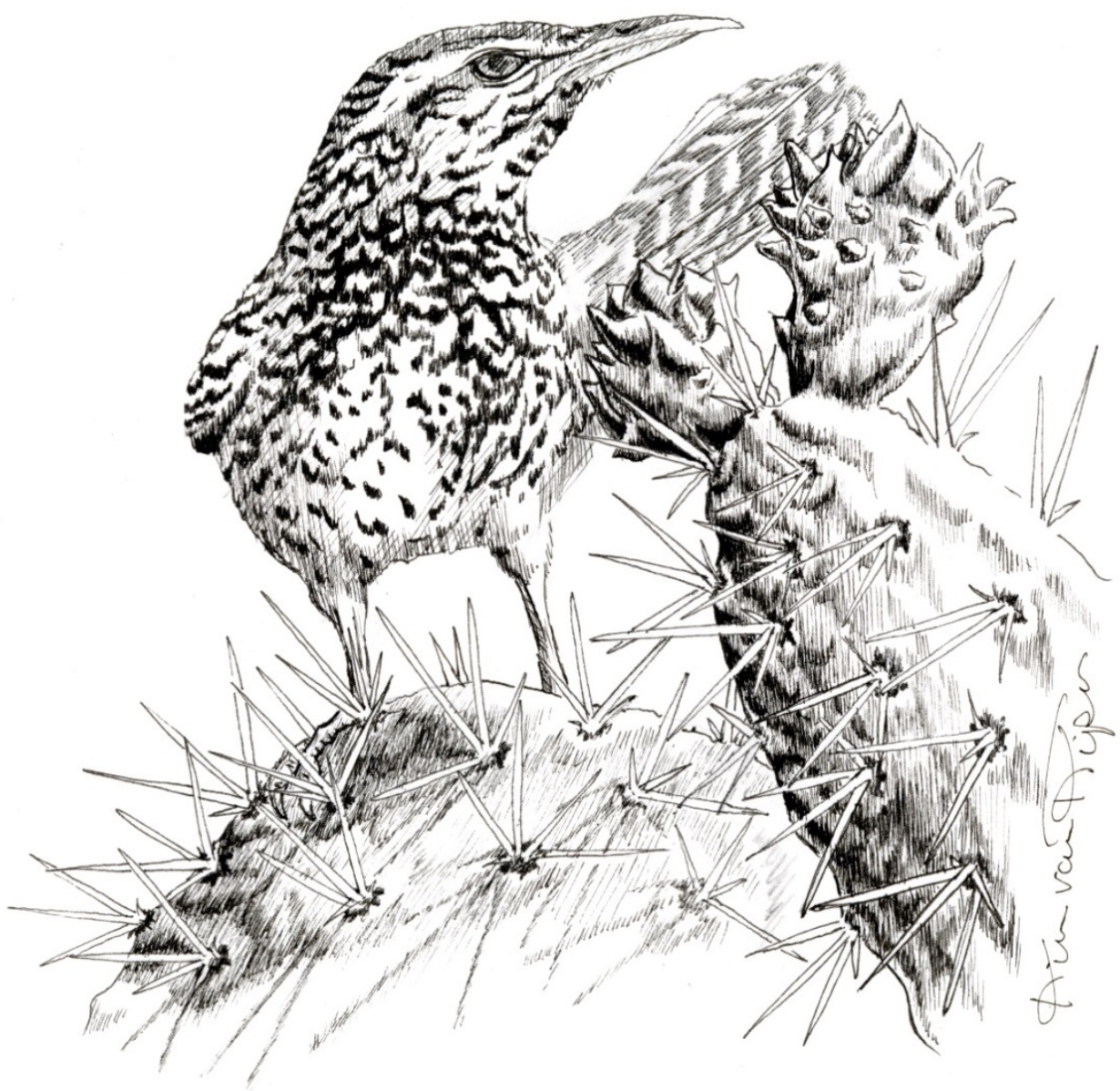

Drawing of cactus wren, Campylorhynchus brunneicapillus (copyright and courtesy of Kimberly Ann van Riper). 


\title{
Proceedings of the Ninth Biennial Conference of Research on the Colorado Plateau: Shaping Conservation Through the Integration of Research in Resources Management on the Colorado Plateau-A Synthesis
}

\author{
Edited by Charles van Riper III, Brian F. Wakeling, and Thomas D. Sisk
}

In published reviews of the previous eight volumes of the Colorado Plateau series, book reviewers suggested that a synthesis chapter would be a useful addition in subsequent volumes (Fleming 2006, Quartaroli 2007). Because all of the Colorado Plateau books present widely disparate facets of research, and every volume has chapters that span aspects of cultural, physical, and biological sciences, these reviewers felt that a closing summary chapter would help readers to better synthesize the disparate topics. This fourth volume from the University of Arizona Press (the ninth in the full Colorado Plateau series) has the same broad span of material as previous volumes, and this summary chapter will attempt to tie together the other chapters of the book.

The sixteen chapters within this book represent the results of fifteen studies and two panel discussions from the Biennial Conference; they are presented in four sections according to overarching topics: 1) conservation visions and frameworks, 2) assessing monitoring frameworks and systems, 3) wildlife surveys as a conservation framework, and 4) large mammal conservation and management. Many of the chapters address conservation and management issues of multiple resources; as a group, they address diverse resources from various geographic regions over the Colorado Plateau. Some chapters explain integrative tools that can be used to manage resources at broader geographic scales, which we now recognize is important for sustain many ecological functions. This book, drawn from the Ninth Biennial Conference of Research on the Colorado Plateau, focuses more heavily on conservation than did the previous eight volumes, with an emphasis on assessing monitoring frameworks and wildlife research, in concert with a presentation of conservation success stories.

\section{Conservation Visions and Frameworks}

The book begins with a section that speaks to the broadest conceptual scope-conservation visions and frameworks. These chapters set a foundation for directions that future conservation can take on the Colorado Plateau, particularly in light of ongoing climatic change. The first chapter, by Jones et al., provides a summary of the Conservation Biology Panels that were held 30-31 October 2007 during the Ninth Biennial Conference. Drawing on presentations and discussions in these panels, Jones and several co-authors convey the broad range of the participants' impressions and suggestions on how conservationists need to "carry on" in an era of explosive population growth, habitat loss and fragmentation, and climate change that collectively place increasing stress on the vulnerable ecosystems and biodiversity of the Colorado Plateau. Panel members - among the most active and experienced scientists working in the region-were asked to evaluate how their individual research and related efforts had served the Colorado Plateau, and assessments were modest and often equivocal. From these exchanges, a general consensus emerged that successes had not fully matched early expectations, and that future successes would demand novel approaches and great creativity. Panel members advocated for greater integration of the natural and social sciences, for more attention to garnering and sustaining political support, and for a renewed pursuit of aesthetic and spiritual appreciation that can help maintain focus and motivation among conservationists. With few exceptions, the panelists, mostly research 
scientists, deemphasized new research needs while highlighting the importance of improved public communication, engagement of broader constituencies, and social processes to inform conservation goals and objectives. If these perceptions represent the thoughts, feelings, and aspirations of the broader community of scientists and land managers concerned with conservation, this chapter may well define a turning point in conservation action over the Colorado Plateau.

Chapter 2, by Garfin et al., presents the results of down-scaled projections of climatic models for projecting possible climatic changes over the Colorado Plateau region. As climate change exerts a stronger influence on Colorado Plateau ecosystems, it becomes increasingly important to incorporate insight from climate models into future management planning. The authors address the issue of downscaled projections of climatic models, demonstrating approaches for managers that highlight how downscaling regional climate models can be integrated with the ecological process models, and how they can be directly related to conservation and management of resources. By exploring the suite of models currently available to researchers and providing techniques for model integration, the authors take a big step forward in bringing climate change research into a management-relevant framework. They anticipate that, in the future, linking downscaled climate models to a host of management applications will allow a more seamless and repeatable way to project the effects of change and the efficacy of management responses to changing resources.

The conservation visions and framework section of this book is tied together with Chapter 3, by Sisk et al., who describe the acquisition and conservation-based management of the Kane and Two Mile Ranches north of the Colorado River in Arizona. The purchase of these ranches by the Grand Canyon Trust and The Conservation Fund, and the initiation of management-driven research efforts, provides an example "par excellence" of how landowners, managers, and scientists can work with the public to integrate restoration and conservation at broad geographic scales by developing novel public/private partnerships. These authors illustrate how rangeland ecologists, soils scientists, remote-sensing technicians, fire ecologists, wildlife biologists, silviculturalists, and livestock producers can use science to articulate objectives, integrate efforts, and guide adaptive management. Four case studies describe this approach. The first study addresses post-fire management of forested habitat following the Warm Fire in 2006. The second study delves into the intricacies of restoring winter range for mule deer, an effort complicated by historical wildfires, livestock grazing, and the spread of undesirable invasive plant species. The third study focuses on challenges in restoring native cool-season grasses, which on paper may seem to be a fairly straightforward procedure, but is in fact subject to many environmental vagaries that demand careful planning, with attention to climate, timing, and soil disturbance. The final case study describes the use of geospatial modeling to identify risk for cheatgrass invasion and how managers might use that information to prioritize landscapes for restoration efforts. Preliminary models were appraised for overall accuracy using accepted evaluation criteria and these models were employed to evaluate possible impacts of planned management treatments, with respect to the likelihood of cheatgrass spread. By documenting the employment of a spatial decision-support system for vegetationand ranch-planning efforts, Chapter 3 outlines one of the first demonstrations and tests of how science can provide an analysis of land cover for the management of lands on the Colorado Plateau. It also highlights the capability of private (nongovernmental) organizations to facilitate this kind of collaboration, blending disciplines to integrate research with adaptive management on the Colorado Plateau. This conservation approach sets a new benchmark that could be applied broadly within the field of natural resources. 


\section{Assessing Monitoring Frameworks and Systems}

Chapter 4, by Garman et al., transitions into the "assessing monitoring frameworks" portion of this book. Monitoring has been a perennial topic of discussion among scientists, resource managers, and participants of every previous Biennial Conference (e.g., Sisk et al., 1999). The authors incorporate protocols from the National Park Service (NPS) Inventory and Monitoring Program (I\&M) specifically related to soil inventory surveys. The initial data were collected in Canyonlands National Park, and then tested in Capital Reef National Park.

The authors note that many NPS areas have existing soil maps, but most maps are at a coarse resolution, and this lack of detail is not conducive to choosing sites for soil study. In order to refine the selection of locations for soils inventories, they implemented two predictive mapping methods: (1) feature-extraction maps and (2) decision-tree models. In their modeling efforts, Garman and his coauthors found that the number, and even types, of ecological sites within a map-unit polygon can differ considerably from a described average. Using existing soil maps to define the spatial extent of targeted ecological sites can lead to over-estimation of the number of targeted ecological sites and the selection of numerous monitoring samples in non-targeted ecological sites. This result led to the modeling efforts, with the decision-tree being identified as the most efficient approach, overall. Garman et al. propose that the advantages of predictive mapping of ecological site types outweigh the costs of model-development efforts. They argue that it is reasonable to assume that feature-extraction is the method of choice where spectral and contextual features are largely different among targeted ecological sites. They further suggest that with the planning horizon $(80+$ yrs) for monitoring programs such as the NPS Northern Colorado Plateau Network I\&M, developing an effective survey design has long-term benefits. Moreover, they note that in remote areas over the Colorado Plateau where travel time to sampling locations can constitute the bulk of monitoring costs, increased efficiency of modeling can bring a substantial benefit to long-term monitoring.

In Chapter 5 Lauver et al. continue the theme of monitoring and habitat modeling, using a case study at Bandelier National Monument where they examined the implications of modifying statistically robust designs to account for logistical feasibility. By taking a quantitative look at the extent to which changes affect soil and vegetation monitoring results, they provide a sound footing for future consideration of the way in which scientific robustness and practical limitations can be negotiated between parties cooperating to achieve effective and efficient monitoring, the results of which will guide adaptive management. By incorporating an experimental component to applied work at Bandelier National Monument, they also demonstrated that incisive science can be combined with programmatic activities, another requirement for any successful adaptive management program. They suggest that these new monitoring programs will allow land managers, policy makers, and planners to make betterinformed land-use decisions, especially throughout northwestern New Mexico. It is clear that this sort of practical approach to monitoring is essential for the implementation of adaptive management, and this chapter offers insight into issues that will need to be examined and resolved during the critical design stage of any monitoring effort.

The "Assessing Monitoring Frameworks and Systems" section continues with a chapter by Yamamoto et al., who discuss the development, construction, and deployment of a wireless cyberinfrastructure for environmental monitoring. The authors suggest that with the increasing complexity of ecological questions, it is imperative that scientists have the correct tools to collect environmental data. They also argue that the WiSARD-Net (Wireless Sensing And Relay Device Network) that they have developed will fit the needs of scientists who need environmental information. The WiSARD-Net system that Yamamoto et al. have developed is simple, yet elegant. It can collect meteorological data (e.g., air and soil temperature, humidity) and also photosynthetically active 
radiation measurements. The environmental information is collected continuously and downloaded directly to a computer. Chapter \#6 presents a test that was run on the WiSARD-Net system as a pilot study at the Flagstaff Arboretum and details the lessons learned on this preliminary pilot study. A conceptual model is provided for the system, as well as information on how to make WiSARD-Net run in "real time" for scientists. The authors also provide an overview of WiSARD-Net, showing how to integrate the in situ wireless sensor network and data-center hardware to provide a complete solution for sampling the environment, transferring the information to a networked server, and then displaying the information, via the Web, anywhere in the world. This is certainly a tool that managers and scientists on the Colorado Plateau should seriously consider employing in future environmental monitoring efforts.

Vegetation studies are introduced with Chapter 7, where Walter Fertig examines the use of vascular plant taxa to determine existing gaps in protected areas over the Colorado Plateau. Based on the U.S. Geological Survey Gap Analysis Program (GAP) format developed by Scott et al. (1991, 1993), Fertig conducts a comprehensive examination of native plant distributions across the Utah portion of the Colorado Plateau. He provides an original and innovative look at the sufficiency of our current conservation areas network. By consulting botanical databases and examining the existing network of protected areas, he demonstrates that nearly one third of the region's native plant species are currently unprotected. He argues that this is a sizeable proportion, given extensive federal ownership and the existing broad interagency mandate for protecting native species and the ecosystems upon which they depend. Furthermore, Fertig identifies those areas in which the biggest gaps in the protection network occur, concluding that 70 percent of the unprotected taxa occur in just 12 plant diversity hotspots, demonstrating that future expansion of the region's network of conservation areas could be pursued with great efficiency, using the existing "gaps" identified in this chapter.

Chapter 8 concludes the set of five chapters of the "Assessing Monitoring Frameworks and Systems" section. In this chapter Poff et al. analyze how fire and fire surrogate treatments impact soil moisture conditions in southwestern ponderosa pine forests. The authors argue, as did Garret et al. (1997) in an earlier book in the Colorado Plateau series, that ponderosa pine forests since at least the early 1900s have exhibited substantial increases in small-diameter pines and decreases among the largest classes of trees, a change largely due to selective logging and reduced fire frequencies since the late 1800s. Garret and Soulen (1999) also suggested that declines in large-diameter trees were due to competition for limited moisture with burgeoning smaller trees. Working under the U.S. Forest Service Fire and Fire Surrogates Program, Poff et al. had two major objectives: (1) to determine the small-scale hydrologic responses of ponderosa pine in Arizona to operational fuels treatments and (2) to gather information on the soil moisture that will be available to plants in different rooting depths as well as for soil microbiology processes on similar soils. The authors found no statistical significant differences between aspects, treatments, or stand density (basal area), as related to soil moisture, a finding that they attribute to the high variability among plots in the same treatment areas. However, either the "cut-andburn" or "burn-only" treatment units had the highest soil moisture content throughout the year at all depths. Considering that fire used to be a natural part of the southwestern ponderosa pine ecosystem, this is an important observation. The authors suggest that future studies should look at fire and fire surrogate treatments at other locations in southwestern ponderosa pine forests, and those with different soil types.

\section{Wildlife Surveys as a Conservation Framework}

The next quartet of chapters covers management aspects of using wildlife surveys as a framework for conservation on the Colorado Plateau. In Chapter 9, Nowak and Persons use long-term monitoring data for milksnakes from Petrified Forest National Park (Holbrook, Arizona) to describe 
survey efforts for this cryptic reptile. Despite the fact that milksnakes are widely distributed throughout much of the United States and South America, they are difficult to detect and, thus, information regarding their status is difficult to acquire. Building on previous work (Drost et al. 2001), Nowak and Persons employed a variety of survey methodologies, including nighttime and daylight driving, walking and bicycling surveys, pitfall traps and cover arrays, box traps and drift fences, and radio-telemetry monitoring of captured animals. They suggest that nighttime driving surveys may be the single most efficient and effective method for determining long-term trends in milksnake abundance.

In Chapter 10 Graham et al. provide an assessment of the effects of the pesticide Diflubenzuron, a treatment applied for Mormon Cricket control, on non-target arthropod communities. This chapter provides a wealth of information on insect species present within habitats of northwestern Utah. In a unique application of inventory techniques, documenting invertebrate species assemblages along a pesticide disturbance gradient, Graham et al. examine the potential impact of Diflubenzuron to all arthropod communities both proximately and ultimately, thus the importance of this study. The authors found a wide variety of Coleoptera, Diptera, Hemiptera, non-ant Hymenoptera, Lepidoptera, Orthoptera, and Scorpiones susceptible to Diflubenzuron, with some differences attributed to specific aspects of the three sampled locations. The authors demonstrate, through the use of principal components analysis, that there may be a lag effect of up to one year on assessing the true impact of Diflubenzuron on arthropod communities. They conclude this chapter urging continued monitoring, which would provide managers with a better understanding of the long-term potential impacts of spraying to invertebrate species within the Desert Southwest.

In Chapter 11, the survey theme shifts to the examination of birds, as Johnson et al. examine the distribution and habitat associations of the Yellow-billed Cuckoo throughout the state of Arizona. By examining historical records, the authors determined that Yellow-billed Cuckoos and their breeding habitat are likely substantially less common in Arizona today than they were in the late 1800s and early 1900s. In their statewide survey in 1998 and 1999, Yellow-billed Cuckoos were primarily detected around the San Pedro River, Cienega Creek, Verde River, Sonoita Creek, and the Agua Fria River. The authors affirm that changes to Yellow-billed Cuckoo habitat and distribution can be linked largely to the well-documented changes to historical flows in Arizona's rivers and periodic flood-dependent riparian habitat, along with habitat fragmentation due to agricultural development, invasive exotic vegetation, and urbanization.

In a second chapter on monitoring birds, van Riper et al. examine differences in population trends of birds in the Camp Verde region of central Arizona. Chapter 12 provides the results of an inventory and long-term monitoring effort documenting birds reported at the Montezuma Castle National Monument complex and the surrounding Camp Verde region of Central Arizona. The authors compared historical records in the published literature, detections by qualified volunteer observers, and recent surveys they had conducted to determine trends in species at the national monument and throughout the Camp Verde region. This chapter provides a detailed account of the status of more than 200 species, giving information on residency status, dates present, breeding status, abundance, and preferred habitat type. Of those bird species that have been detected within Montezuma Castle National Monument, the authors found that 14 species have increased, whereas six have declined in abundance. They conclude that much of the changes observed in avian community composition are likely due to large-scale changes (e.g., urbanization) outside of the region. Only a few changes in bird status can be tied directly to management actions taken within Montezuma Castle National Monument or the Camp Verde region. 


\section{Large Mammal Conservation and Management}

The final four chapters of the book move from large biological surveys to the management and conservation of large mammals on the Colorado Plateau. In Chapter 13 Wakeling presents the current status and historical changes in management for trophy deer on the Kaibab Plateau. This chapter provides a much needed summary of numerous years of biological inventory undertaken on the Kaibab deer herd. The author compares results of hunter check-station information from Jacob Lake prior to and after the implementation of a 2001 change in hunting quotas set by the Arizona Fish and Game Department. Wakeling found that deer maximum-mean outside antler spread was reached at five years of age. The new 2001 regulations had little effect on the size of deer taken, except that older deer were taken later in the hunting season. The author concludes that state management of the Unit 12A Kaibab deer hunt is successful, largely meeting the needs of the hunting public, while properly managing for trophy-class bucks.

In Chapter 14, Bristow and Cunningham report on the use of habitat by female elk, subsequent to the Rodeo-Chediski fire that occurred in east-central Arizona in 2002. This stand-replacing fire consumed almost 185,000 ha of ponderosa pine forest below and above the Mogollon Rim. While unplanned, the fire provided a valuable opportunity to learn how elk use altered habitats. The authors note that in this case favorable precipitation patterns that immediately followed the fire probably enhanced forage growth. They found that after the fire, female elk selected ponderosa pine-oak habitats with 40-60 percent canopy closure in the heavy-to-extreme burn intensity regions. This trend was consistent through the winter, spring, and summer seasons during both daylight and nighttime hours. In autumn, female elk shifted to light-to-medium burn intensity regions, although still using ponderosa pine-oak habitat with 40-60 percent canopy closure. Bringing this study to bear on land management, Bristow and Cunningham recommend prescribed fire that retains mosaics of moderate canopy closure and forage in order to improve elk habitat.

Chapters 15 and 16 both look at managing and conserving predators on the Colorado Plateau, as well as specific survey methodology. In Chapter 15 McKinney and Smith report on the efficacy of scent-station transects for indexing mesopredators. The authors investigated visitation by bobcats, coyotes, and foxes throughout chaparral, pinyon-juniper woodland, ponderosa pine forest, semi-desert grassland, and Upper Sonoran Desert scrub habitats throughout Arizona. They conclude that this technique, while ineffective as a bobcat population index, does provide a reliable method for tracking relative abundance of coyote and fox populations in most habitat types (with the exception of coyotes in ponderosa pine habitats, where they did not visit scent stations). The authors caution against drawing conclusions about changing bobcat numbers among habitat types, but argue that scent-station transects can provide a reliable method of comparing relative abundance of foxes and coyotes between time periods (or locations) within specific habitat types.

In the final chapter of the large mammal conservation and management section, McKinney et al. provide a summary and analysis covering 29 years of mountain lion depredation harvests in Arizona. For the period from 1976 through 2005, they examined existing records to see if mule deer abundance was inversely related to livestock depredation. The authors found that more than 90 percent of livestock depredation by mountain lions targeted cattle, and almost all of those cases involved calves. Mountain lions that were killed as a result of livestock depredation were taken in 12 of the Arizona's 15 counties, but 92 percent of those lions were taken within five counties. The authors also note that most lions taken after killing livestock were adult males. After comparing the statistics, the authors concluded that a reduced relative abundance of mule deer does contribute to greater depredation of cattle, and consequently to more lions being killed for livestock depredation. Studies such as this one and the 
others in this section provide invaluable data that both land managers and biologists can draw upon in evaluating both harvest and conservation programs proposed in coming years.

The scientific works published in this series of books, based on the biennial conferences of research on the Colorado Plateau, present the results of collaborative efforts between scientists and land managers and contribute significantly to the peer reviewed literature. We have found that many of the protocols and management techniques presently being used in land management units over the Colorado Plateau are a result of past collaborative works published in this series, including those of federal scientists working jointly with university and other partner agency scientists, and with land managers from a variety of states (e.g., the region's Wildlife and Game and Fish Departments). It has been clearly demonstrated that techniques that work in one management unit of the Colorado Plateau are applicable to a number of other areas, a fact due primarily to the similarity of habitat and climatological conditions across the region.

Like other research compilations that are centered on a particular theme, this book should help to focus attention on research and conservation efforts presently being conducted within diverse habitats over the Colorado Plateau. In particular, we hope that private land owners and state-land stewards of Arizona, Utah, Colorado, and New Mexico, as well as managers of National Parks, National Monuments, National Forests, Fish and Wildlife Service refuges, Bureau of Land Management districts, Bureau of Reclamation waters, and tribal lands will be able to make good use of the ideas and concepts presented within this book. We hope that the new information presented in these chapters will allow land stewards to undertake more effective and efficient efforts in the management, conservation, and stewardship of southwestern lands and natural resources. Finally, if the material in this volume can stimulate support for future research in the conservation and management of cultural, natural, and physical resources over the Colorado Plateau, it will make the organizational and editorial work of the past two years a worthwhile and productive effort.

\section{Abstracts}

THE LEGACY AND FUTURE VISIONS OF CONSERVATION BIOLOGY ON THE COLORADO PLATEAU

Allison L. Jones, Ethan N. Aumack, Jan Balsom, Paul Beier, Jayne Belnap, James C. Catlin, Thomas L. Fleischner, Ed Grumbine, David J. Mattson, and Charles van Riper III

This paper summarizes a half-day panel discussion and larger audience discussion on a topic that doesn't receive enough attention at the scientific conferences we all attend: collectively reflecting on how our individual research and efforts have served the Colorado Plateau for the past several decades. And, what do we need to do more of in the future to assure the preservation of biological diversity in this magnificent region? During the 2007 USGS conference at Northern Arizona University, the Colorado Plateau Chapter of the Society for Conservation Biology held a two-part session, discussing first with our distinguished panelists what strategies have either forwarded, or hindered, the understanding and protection of biodiversity on the Plateau. In the second session, we hypothetically traveled forward in time to develop visions of a future for conservation biology on the Plateau within the context of current (and future) challenges such as a changing climate and shifting human demands for natural resources. Our panelists, all leaders in the field of conservation biology, gave us many valuable "take-home lessons," ranging from the benefits of collaboration with non-scientists, to how to deal with the influence of political processes in the scientific realm, to the power of hope to sustain conservationists through tough times. Overall, a common thread among the presenters was one of using beneficial lessons learned to proactively and effectively work towards a positive future for our Colorado Plateau landscapes and wildlife. 
DOWNSCALING CLIMATE PROJECTIONS IN TOPOGRAPHICALLY DIVERSE LANDSCAPES OF THE COLORADO PLATEAU IN THE ARID SOUTHWESTERN UNITED STATES

Gregg M. Garfin, Jon K. Eischeid, Melanie Lenart, Kenneth L. Cole, Kirsten Ironside, and Neil Cobb Global Climate Models (GCMs) operate at scales much larger than the federal and state forest, range and riparian ecosystems managed by land and water professionals. Therefore, incorporating information on climate change projections into resource management plans requires GCM projections at a scale more relevant to ecosystems, especially in topographically diverse regions such as the western United States. In an effort to address this need, we developed downscaled climate projections for the Southern Colorado Plateau (SCP) $\left(35^{\circ}\right.$ to $38^{\circ} \mathrm{N}, 114^{\circ}$ to $\left.107^{\circ} \mathrm{W}\right)$, centered on the Four Corners states. We compared twenty-two global climate models (GCMs) from the archive of model runs used in the Intergovernmental Panel on Climate Change Fourth Assessment Report, and statistically downscaled them to a $4 \mathrm{~km}$ grid, to accord with spatially and temporally continuous historic observations using the Parameter-elevation Regressions on Independent Slopes Model (PRISM) data set. From these results, we selected five models representing a range of plausible possible climate futures. We consider them in the context of three seasonal time frames observed to be critical for vegetation in the SCP: winter (November-March), arid foresummer (May-June), and summer monsoon (July-September).

Projections for the SCP describe a warmer future, in which annual temperatures seem likely to increase by $1.5^{\circ}$ to $3.6^{\circ} \mathrm{C}$ by mid-century, and $2.5^{\circ}$ to $5.4^{\circ} \mathrm{C}$ by the end of the century, depending on the model chosen. Annual temperatures are projected to exceed the 1950-1999 range of variability by the 2030s. Annual precipitation changes are more equivocal. A conservative estimate, using a 22 -model ensemble average, indicates that SCP annual precipitation may decrease by $6 \%$ by the end of the century. For precipitation projections, GCM agreement is greatest for the May-June arid foresummer season, and projections show SCP May- June precipitation declining by 11 to $45 \%$ during the twenty-first century. Downscaled output from this study will be used to drive vegetation change models with the intent of examining a diversity of possible outcomes so scientists can test an array of vegetation changes, and resource managers can make informed decisions in relation to the range of possible climate change scenarios.

INTEGRATING RESTORATION AND CONSERVATION OBJECTIVES AT THE LANDSCAPE SCALE: THE KANE AND TWO MILE RANCH PROJECT

Thomas D. Sisk, Christine Albano, Ethan Aumack, Eli J. Bernstein, Timothy E. Crews, Brett G. Dickson, Steve Fluck, Melissa McMaster, Andi S. Rogers, Steven S. Rosenstock, David Schlosberg, Ron Sieg, and Andrea Thode

Across the Colorado Plateau, conservation and restoration projects are progressing in a dizzying array of overlapping efforts. Increasing the efficiency and effectiveness of these efforts requires integration at scales relevant to multiple ecological processes and management practices. While watersheds provide natural and discrete units for organizing and coordinating efforts in many regions, the unique geomorphology and land tenure of the Colorado Plateau suggests a landscape-scale approach for organizing restoration and conservation efforts. In 2005, the Grand Canyon Trust and The Conservation Fund purchased the historic Kane and Two Mile Ranches and initiated an experiment in public-private partnership in science and land management spanning 340,000 ha of the Arizona Strip, including some of the West's most remote places and spectacular scenery. This effort provides an ongoing case study of how collaborative projects are promoting new understanding and strategic approaches to landscape planning and management efforts that cross ecosystem and jurisdictional boundaries. In this chapter, we present four ongoing projects that illustrate the interrelationships 
between research and management: 1) the influence of severe fire on plant communities and fuels, 2) native shrub restoration and habitat improvement efforts for mule deer (Odocoileus hemionus), 3) restoration of native cool-season grasses in the House Rock Valley, and 4) the development of spatial models to predict the occurrence of cheatgrass (Bromus tectorum). Together, these efforts illustrate the value of integrating research efforts to guide a landscape-level conservation and restoration program that is visionary, scientifically grounded, and practical.

\section{MAPPING ECOLOGICAL SITES FOR LONG-TERM MONITORING IN NATIONAL PARKS Steven L. Garman, Dana Witwicki, and Aneth Wight}

The Northern Colorado Plateau Inventory and Monitoring Network (NCPN) of the National Park Service is responsible for the design and initiation of long-term monitoring of upland ecosystems across 16 National Park units on the Colorado Plateau. Monitored indicators include soil properties, as well as vegetation structure and composition. Targeted populations for monitoring are defined by individual ecological site types, which have variable resistance to disturbances. Monitoring of individual ecological sites largely ensures sufficient samples for status and trend evaluations, and facilitates interpretation of observed changes in indicators on the basis of soil and other properties. The sampling and survey design approach used by the NCPN requires explicit mapping of ecological sites. Existing soil surveys provide maps of soil map units that can contain one to many ecological sites and provide estimates of site proportions within a map unit. We used two predictive mapping methods to enhance the mapping of ecological sites from existing soil maps. Methods included feature-extraction modeling, which employs machine-learning algorithms to generate feature extraction rules, and decision tree models. Feature-extraction methods were applied to selected ecological sites in Canyonlands National Park, and both methods were used to map selected ecological sites in Capitol Reef National Park. Models were parameterized and tested using field samples of ecological sites. Prediction accuracy of the feature-extraction model in Canyonlands National Park ranged from 64 to 71 percent for three of the five target ecological site types, but overall accuracy was only 43 percent. A hierarchical re-learning process with enhanced training samples improved overall accuracy to 75 percent, although accuracy of the re-learned models was based on model-development data. Decision-tree models for Capitol Reef National Park separated non-targeted from targeted site types, but predicted mixtures of targeted ecological sites. Prediction accuracy for these mixtures was 52 to 65 percent. Feature-extraction models developed to predict one of the ecological site mixtures in Capitol Reef National Park were as accurate as the decision tree models. To determine accuracy and efficiency gains with predictive mapping, Monte Carlo simulations were used to estimate potential "accuracy" in locating a targeted ecological site within soil map units using only the reported distributional percentages. Compared to simulations, both predictive mapping methods afforded greater accuracy in mapping ecological sites, which translates operationally to greater efficiency of sample selection. Small sample sizes and lack of independent data for testing re-learned feature-extraction models limited the rigor of model comparisons and assessments. Despite these limitations, results of this study indicate the potential for predictive mapping methods to enhance the spatial delineation of ecological sites. The advantage of enhanced mapping of ecological sites is increased efficiency of sampling designs for monitoring, and more exact delineation of the spatial extent of targeted populations and, thus, sampling inference.

QUANTIFYING SAMPLE BIAS IN LONG-TERM MONITORING PROGRAMS: A CASE STUDY AT BANDELIER NATIONAL MONUMENT, NEW MEXICO Chris L. Lauver, Jodi Norris, Lisa Thomas, and Jim DeCoster 
The Southern Colorado Plateau Network (SCPN) of the National Park Service (NPS) is developing a long-term program to monitor the condition of natural resources at 19 NPS units on the Colorado Plateau. We present a case study of our soil and vegetation monitoring at Bandelier National Monument and quantify bias associated with our sampling design. To stratify natural variation in soils and vegetation for sampling, we selected soil map units from a recent soil survey to represent the initial spatial sampling frame. In modifying the sampling frame to select monitoring sites that are logistically feasible, a large portion of the frame was found to contain undesirable elements, including steep slopes and inaccessible areas. Removing these areas resulted in a final sampling frame that contained only $37.2 \%$ of the initial frame area. We tested for a bias in the distributions of elevation, slopes, and soils between the initial and final sampling frames, and for a site selection bias of these same features by comparing potential sampling sites to the final sampling frame. Mean percent slope for the initial frame was significantly higher than that of the final frame, and mean elevation for the initial frame was significantly lower than that of the final frame. Reasons for these differences include user-specified constraints on slope and accessibility. No bias was found in soil features between the initial and final sampling frames, and no site selection bias was found for slope, elevation, or soils. The analysis provided explicit data on some of the consequences of creating a practical sampling design.

\section{WISARDNET FIELD-TO-DESKTOP: BUILDING A WIRELESS CYBERINFRASTRUCTURE FOR} ENVIRONMENTAL MONITORING

Kenji Yamamoto, Yuxin He, Paul Heinrich, Alex Orange, Bill Ruggeri, Holland Wilberger, and Paul Flikkema

The technology of wireless sensor networks has enabled new levels of spatial coverage and density in the monitoring of variables important in numerous applications, including ecological research and environmental management. These networks are composed of small, energy-efficient devices that wirelessly collaborate to gather data on temperature, light, soil moisture, sap flux, and other variables over space and time. However, a complete monitoring solution requires the conversion of data into useful information for a user, who may be anywhere in the world. To address this challenge, we have designed a complete Field-to-Desktop system for the acquisition, storage, and visualization of environmental data from a wireless sensor network using industry-standard networking, database, and web-development tools. This paper describes the architecture and capabilities of the system and lessons learned from a test implementation designed for public outreach at The Arboretum at Flagstaff.

\section{FINDING GAPS IN THE PROTECTED AREA NETWORK IN THE COLORADO PLATEAU: A CASE STUDY USING VASCULAR PLANT TAXA IN UTAH \\ Walter Fertig}

About 19 percent of the Colorado Plateau region of Utah is currently under some form of permanent protective status. Most of these protected areas, however, were established for their scenic, cultural, or recreation value rather than for conservation of biological diversity. I used gap analysis methods to determine how well vascular plant species are represented in the existing protective network and to identify types of species, habitats, and geographic areas that are unprotected. At present 1948 of the 2859 species in the study area $(68.1 \%)$ occur in permanent and highly protected areas (equivalent to GAP Status 1 or 2 lands), while 911 taxa (31.9\%) are unprotected. Among the species on protected lands, 438 (22.5\%) are Colorado Plateau endemics and 419 (21.5\%) are listed as rare by the Utah Natural Heritage Program, while 1510 (77.5\%) are widespread native or non-native species and 1529 (78.5\%) are considered common. By comparison, plateau endemics (288 taxa) comprise 31.6 percent of the unprotected flora, and rare species (345 taxa) comprise 37.9 percent. Unlike distributions in most 
Gap studies, species from high elevation habitats in the Colorado Plateau are less likely to be protected than those from desert shrub, sagebrush, and pinyon- juniper communities. Almost 70 percent of the unprotected taxa occur in just 12 plant-diversity hotspots that are not currently part of the state's protected area network.

\section{FIRE AND FIRE SURROGATE TREATMENT IMPACTS ON SOIL MOISTURE CONDITION IN SOUTHWEST PONDEROSA PINE FORESTS}

Boris Poff, Daniel G. Neary, and Aregai Tecle

An experimental Fire and Fire Surrogate study (FFS) demonstrates use of silvicultural practices to replace and/or augment fuel reduction strategies in the semi-arid Southwest. The FFS study incorporates soil-moisture measurements into the existing experimental design. The data gathered in this study provide information on the amount of soil moisture available to plants at different rooting depths. Permanent plots have been established for the application of four treatments (control, burn only, cut only \& cut and burn). Each treatment consists of 36 permanent plots. The soil-moisture-availability study was conducted near A1 Mountain in northern Arizona. There, ten permanent plots from each treatment were selected for installing semi-permanent soil-moisture probes. Of the ten plots, four were equipped with $15 \mathrm{~cm}$ probes, another four plots with $30 \mathrm{~cm}$ probes, while the remaining two plots have both 15 and $30 \mathrm{~cm}$ probes. Data were collected on a monthly basis from April 2006 to March 2007. An extensive statistical analysis of the soil moisture data was conducted, and the results of this study indicate no statistical significant difference between aspects, treatments, or stand density (basal area). However, some soil moisture trends are noticeable. Either the cut and burn or burn only units had the highest soil moisture content throughout the year at either depth.

\section{MILKSNAKES AT PETRIFIED FOREST NATIONAL PARK, ARIZONA: ADAPTIVE MONITORING OF RARE VERTEBRATES}

\section{Erika M. Nowak and Trevor B. Persons}

Milksnakes (Lampropeltis triangulum) are widely distributed across the United States and into South America, and are represented in northern Arizona by a diminutive form. Due to its apparent rarity and unique characteristics, this form is popular with snake collecting enthusiasts. Surveys conducted adaptively at Petrified Forest National Park (NP) between 1997 and 2007 suggest that the park may serve as an important protected site for the species in Arizona. Survey methods included quantitative night driving and bicycling surveys; nocturnal and visual encounter (walking) surveys; pitfall trap and artificial cover arrays and transects; radio-telemetry; and box trap, drift fence, and artificial cover transects. We found a total of 25 individual milksnakes over a 10-year period, and we report additional detections by NPS staff between 1995 and 2007. Controlling for seasonal differences in sampling effort, night-walking surveys during the late summer and use of box trap and drift fence transects in the spring produced the most animals per person-hour of effort, while night driving with an all-terrain vehicle (ATV) during the late summer produced the most animals per kilometer. However, detectability was extremely low in all methods. A short-term, late-summer telemetry study indicated extensive use of underground features (burrows) and suggested localized movements. We compare inter-annual detections of milksnakes during night driving surveys with those of other snake species. We conclude by discussing the implications of low detection rates for the status of milksnakes at Petrified Forest NP and make suggestions for future research and monitoring.

MORMON CRICKET CONTROL IN UTAH'S WEST DESERT: EVALUATION OF IMPACTS OF THE PESTICIDE DIFLUBENZURON ON NON-TARGET ARTHROPOD COMMUNITIES 
Tim B. Graham, Anne M. D. Brasher, and Rebecca N. Close

Grasshopper and Mormon cricket (Orthoptera) populations periodically build to extremely high numbers and can cause significant economic damage in rangelands and agricultural fields of the Great Plains and Intermountain West. A variety of insecticides have been applied to control population outbreaks, with recent efforts directed at minimizing impacts to nontarget fauna in treated ecosystems. A relatively new insecticide for control of Orthoptera is diflubenzuron, which acts to inhibit chitin production, ultimately causing death during the molt following ingestion of the insecticide. All arthropods, including insects, mites, and crustaceans, use chitin to build their exoskeletons and will die if they are unable to produce it during the next molt. Diflubenzuron is not taxon specific - it affects all arthropods that ingest it, except adult insects, which do not molt. Consequently, application of this pesticide has the potential to significantly reduce not only target populations but all terrestrial and aquatic arthropods within treatment zones.

Some research has been done in the Great Plains on the impact of diflubenzuron on nontarget arthropods in the context of grasshopper-control programs, but no work has been done in the Great Basin in Mormon cricket-control areas. This study was instigated in anticipation of the need for extensive control of Orthoptera outbreaks in Utah's west desert during 2005, and it was designed to sample terrestrial and aquatic arthropod communities in both treated and untreated zones. Three areas were sampled: Grouse Creek, Ibapah, and Vernon. High mortality of Mormon cricket eggs in the wet, cool spring of 2005 restricted the agricultural community's need to control Mormon crickets to Grouse Creek. Diflubenzuron was applied (aerial reduced agent-area treatment) in May 2005. Terrestrial and aquatic arthropod communities were sampled before and after application of diflubenzuron in the Grouse Creek area of northwestern Utah in May and June of 2005. In this paper, we discuss only the terrestrial results (aquatic results are available online at http://pubs.usgs.gov/of/2008/1305/). In July 2005, U.S. Geological Survey scientists sampled areas in Ibapah and Vernon that had been treated with diflubenzuron in 2004, along with adjacent untreated areas. Pitfall traps at four treated and four untreated sites were used to collect ground-dwelling terrestrial arthropods. One-year post-treatment samples were collected by using the same methods for arthropods at Ibapah and Vernon in July 2005 (treatments applied in June 2004).

More than 124,000 terrestrial arthropods were collected from the three study areas. Direct effects of diflubenzuron on arthropod communities were not apparent in our data from Grouse Creek. Some trends indicate diflubenzuron may affect some terrestrial taxa. Ant communities showed some differences, with possible lag effects at Ibapah and Vernon. Forelius was more abundant, while Tapinoma and, perhaps, Formica declined in treated zones in these two study areas. Solenopsis also was more numerous at treated Ibapah sites but varied without pattern at Vernon. Scorpions were abundant at Grouse Creek and Ibapah but rare at Vernon. Numbers did not change during several weeks at Grouse Creek, but at Ibapah, numbers at treated sites were much lower than at untreated sites. The Lygaeidae (in the order Hemiptera) were more abundant in the untreated zones at Ibapah and Vernon, although significantly so only at Ibapah. Lygaeidae were absent from the treated zone at Grouse Creek (before and after treatment) but were present after treatment in the untreated zone. Additional research is recommended to determine more explicitly whether these taxa are sensitive to diflubenzuron applications in the Great Basin.

YELLOW-BILLED CUCKOO DISTRIBUTION AND HABITAT ASSOCIATIONS IN ARIZONA 1998-1999: FUTURE MONITORING AND RESEARCH IMPLICATIONS

Matthew J. Johnson, Robert T. Magill, and Charles van Riper III 
In 1998 and 1999, we surveyed throughout Arizona areas of suitable habitat in all known riparian drainages historically occupied by Western Yellow-billed Cuckoos (Coccyzus americanus occidentalis). Of the 30-odd drainages identified with historical Yellow-billed Cuckoo detections, 26 drainages had at least one Yellow-billed Cuckoo detection during the 1998-1999 surveys. In 1998 we completed 97 individual surveys resulting in 166 Yellow-billed Cuckoo detections within 22 drainages. Yellow-billed cuckoos were detected in that field season were mainly located along 5 drainages:

Cienega Creek, Sonoita Creek, San Pedro River, Bill Williams River, and the Verde River. In 1999, our survey effort increased, and we completed 169 individual surveys resulting in 404 Yellow-billed Cuckoo detections within 47 drainages. The majority of Yellow-billed Cuckoo detections in 1999 were along the San Pedro River, Verde River, and Cienega Creek. Although the Agua Fria River was not surveyed in 1998, we detected a high number of Yellow-billed Cuckoos there in 1999. Sonoita Creek had a high number of Yellow-billed Cuckoo detections in 1998, whereas in 1999 it only accounted for 6 percent of all detections. In 1999, we had 14 drainages with no Yellow-billed Cuckoo detections. To evaluate our Yellow-billed Cuckoo survey method, we visited sites either once, twice, or three times. During the 1998 and 1999 Yellow-billed Cuckoo breeding season, we found that if a Yellow-billed Cuckoo was detected during the first survey, the probability of detecting Yellow-billed Cuckoos during the second and third surveys was very high.

During both years of this study we found 85 percent of all Yellow-billed Cuckoo detections in native habitat ( $>75 \%$ native species), dominated by cottonwood (Populus spp.), willow (Salix spp.), and mesquite (Prosopis spp.). Yellow-billed cuckoo detections in the mixed native habitat (51-75\% native species) were dominated by cottonwood, mixed with willow and tamarisk (Tamarix spp.). A smaller percent of Yellow-billed Cuckoo detections (5\%) occurred in the mixed exotic category (51-75\% exotic species), which was dominated by tamarisk; however, cottonwood was present at all but two Yellowbilled Cuckoo detection sites within this category. In addition, riparian habitat at sites with Yellowbilled Cuckoo detections of $>5$ had a greater surface area (100 m wide) at its widest point of the drainage than did sites with $<5$ cuckoo detections.

\section{A HISTORICAL ASSESSMENT OF CHANGES IN AVIAN COMMUNITY COMPOSITION FROM MONTEZUMA CASTLE NATIONAL MONUMENT, WITH OBSERVATIONS FROM THE CAMP VERDE REGION OF ARIZONA}

Charles van Riper III, Mark K. Sogge, and Matthew J. Johnson

This chapter is a historical assessment of changes within the 211 bird species that have been recorded as occurring in the National Park Service areas of Montezuma Castle National Monument, including its Montezuma Well unit. There are also observations from the Camp Verde region of the Verde Valley in central Arizona. Information in this assessment is based on an intensive six-year birdinventory project conducted from 1991 through 1997, entailing more than 600 field hours. While our formal surveys were focused at the Montezuma Castle National Monument (MCNM) complex, we made observations throughout the Camp Verde region. Some of the information collected on this project is detailed in Johnson and van Riper (2004), Sogge and Johnson (1998), and Schmidt et al. (2006). We have also used the published literature (e.g., North American Birds), museum specimens, and information generously provided by individuals with many years of experience birding in the Camp Verde region and at the MCNM complex (see acknowledgments). Based on comparisons with historical data, the abundance and status of several species appear to have changed substantially. We discuss species that have increased in numbers, those that appear to have declined, and possible explanations for those changes. We found that most avian species that increased or decreased over the past several 
decades have done so over the entire southwestern United States, not only within the National Park Service areas and the Camp Verde region.

MULE DEER ANTLER GROWTH AND HUNTING MANAGEMENT ON THE NORTH KAIBAB, ARIZONA

\section{Brian F. Wakeling}

Mule deer (Odocoileus hemionus) management must be biologically sustainable and socially acceptable. Social expectations for hunter harvest and hunt quality often place greater restrictions on deer management than do biological limitations. The mule deer herd that inhabits the North Kaibab, Arizona (Game Management Unit 12A) is managed under Arizona Game and Fish Commission alternative deer-management guidelines that were designed to provide lower hunter densities, higher hunt success during late season hunts, and a greater opportunity to harvest an older age-class deer. I compared antler spread, antler points, and cementum age of mule deer bucks harvested on the North Kaibab from measurements taken at a mandatory hunter check station at Jacob Lake, Arizona. Mule deer antler points and antler spread increased with age to 5 years, after which antler points and spread did not substantially increase. Through a public process, the Arizona Game and Fish Commission established alternative deer management guidelines that included permit adjustments for late season hunts to ensure $55-75 \%$ of animals harvested were $\geq 3$ years of age and $20-30 \%$ of the animals harvested were $\geq 5$ years of age.

\section{FEMALE ELK HABITAT USE AFTER THE RODEO-CHEDISKI FIRE IN NORTHEAST ARIZONA}

Kirby Bristow and Stan Cunningham

Between 18 June and 7 July 2002, the Rodeo-Chediski fire burned 184,096 ha of U. S. Forest Service, state, private, and White Mountain Apache Reservation land along the Mogollon Rim of Arizona. Before 1880, Arizona's ponderosa pine (Pinus ponderosa) forest communities, and the elk (Cervus elaphus) that inhabited them, were subjected to large-scale ( $>5,000 \mathrm{ha})$ episodic fires that occurred about every 2 to 10 years. Aggressive suppression of wildfires, historical livestock grazing practices, and timber management practices have rendered ponderosa pine forests in Arizona densely timbered. The over-accumulation of fuels, coupled with persistent drought conditions, have recently resulted in several stand-replacing fires in the western United States, a phenomenon which could be considered ecologically abnormal. Understanding impacts of these stand-replacing fires (such as the Rodeo-Chediski fire) on elk habitat, and how elk use areas recovering from fire could provide insights for improving forest and fire management to protect and enhance wildlife habitat. Beginning three years after containment, we investigated habitat selection and modeled habitat-use by female elk $(\mathrm{n}=11)$ within the boundary of the Rodeo-Chediski fire. Female elk selected ponderosa pine habitats with 40$60 \%$ canopy cover that were classified as subjected to heavy to extreme burn intensity. Favorable precipitation in years following the fire, increased light transmission to the forest floor, and enhanced soil nutrient condition likely enhanced vigorous growth of forbs and shrubs that improved forage conditions and attracted elk. Forest treatments and prescribed fire designed to reduce canopy cover to $40-60 \%$ in a mosaic pattern, while reducing the impacts of roads and vehicle traffic, would likely improve habitat conditions for elk in ponderosa pine communities.

\section{SCENT-STATION SURVEYS: INDEXING RELATIVE ABUNDANCE OF MESOPREDATORS IN ARIZONA}

Ted McKinney and Thorry W. Smith 
We conducted scent-station surveys to index relative abundance of mesopredators (bobcat [Lynx rufus], coyote [Canis latrans], and common gray fox [Urocyon cinereoargenteus]) in five habitats across Arizona during 2004 and 2005. We developed scent-station transects in chaparral, pinyonjuniper (Pinus spp.-Juniperus spp.) woodland, ponderosa pine (Pinus ponderosa) forest, semi-desert grassland, and Upper Sonoran Desert scrub habitats. Bobcats visited scent stations only in chaparral and ponderosa pine forest habitats, and low visitation rates $(\leq 3 \%)$ limit the usefulness of scent-station surveys to monitor long-term changes and trends for this species. Coyotes visited scent stations in all habitat types except ponderosa pine forest, but visitation rates consistently were $<10 \%$, a level that provides for limited usefulness of the survey method. Foxes visited scent-stations in all habitat types, but visitation rates were $>10 \%$ only in chaparral and Upper Sonoran Desert habitats. Among habitats that we surveyed, scent-station surveys may provide more reliable survey indices for foxes than for coyotes, and we suggest that the technique may be of questionable merit for indexing relative abundance of bobcats in all habitat types. Scent-station surveys require large sample sizes, produce highly variable and imprecise results, and are potentially sensitive only to large changes in relative population abundance. Despite finding that scent-station visitation rates for mesopredators we studied often were $<10 \%$, we believe that scent-station surveys can be useful for management purposes. However, we believe that surveys must be habitat- and species-specific to be useful. We conclude that experimental research will be needed to evaluate the sensitivity and power of scent-station surveys for monitoring changes and trends of mesopredator populations in Arizona.

MOUNTAIN LION DEPREDATION HARVESTS IN ARIZONA, 1976-2005

Ted McKinney, Brian F. Wakeling, and Johnathan C. O’Dell

We studied reported kills of mountain lions (Puma concolor) in Arizona related to livestock depredation events between 1976 and 2005 to determine if a relationship existed between mule deer (Odocoileus hemionus) abundance and livestock depredation. Depredation-related kills of mountain lions increased and contributed substantially to statewide hunter harvest of mountain lions when mule deer abundance waned. Depredation-related kills of mountain lions were negatively correlated with mule deer abundance. Depredation-related kills of mountain lions involved primarily adult males, but take of all age and sex classes of mountain lions increased concurrently. Cattle depredation initiated $90 \%$ of all reported mountain lion kills for depredation, and $98 \%$ of these reports involved depredation on calves. Mountain lions killed for depredation of cattle occurred in 12 of the state's 15 counties, although 5 counties accounted for $92 \%$ of all depredation kills. We believe that reduced relative abundance of mule deer contributes to increased depredation of cattle by mountain lions in Arizona.

\section{SHAPING CONSERVATION THROUGH THE INTEGRATION OF RESEARCH WITH RESOURCES MANAGEMENT ON THE COLORADO PLATEAU: A SYNTHESIS Charles van Riper III, Brian F. Wakeling, and Thomas D. Sisk}

In published reviews of the previous eight volumes of the Colorado Plateau series, book reviewers suggested that a synthesis chapter would be a useful addition in subsequent volumes (Fleming 2006, Quartaroli 2007). Because all of the Colorado Plateau books present widely disparate facets of research, and every volume has chapters that span aspects of cultural, physical, and biological sciences, these reviewers felt that a closing summary chapter would help readers to better synthesize the disparate topics. This fourth volume from the University of Arizona Press (the ninth in the full Colorado Plateau series) has the same broad span of material as previous volumes, and this summary chapter will attempt to tie together the other chapters of the book. 


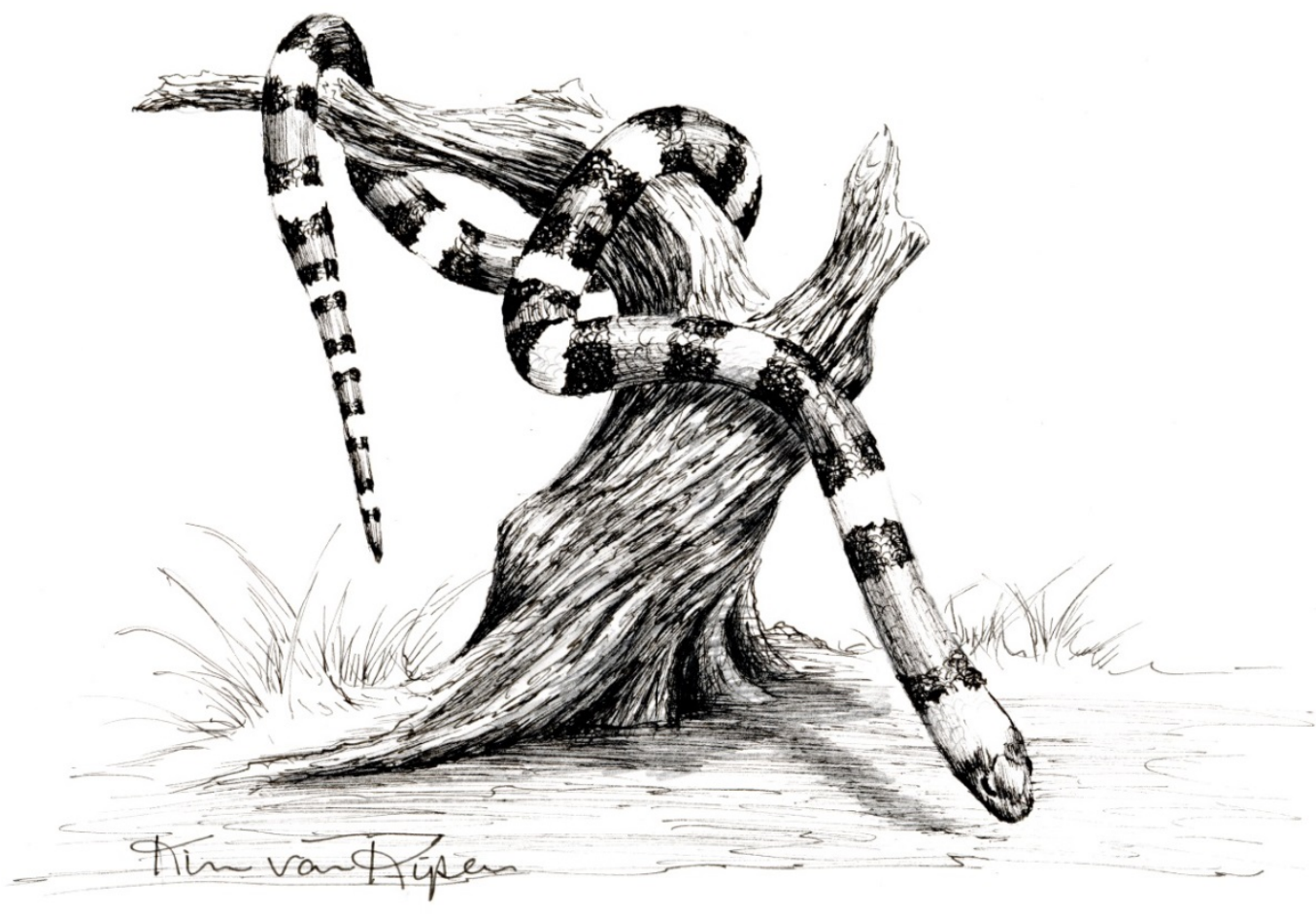

Drawing of milksnake, Lampropeltis triangulum (copyright and courtesy of Kimberly Ann van Riper). 


\title{
Proceedings of the Tenth Biennial Conference of Research on the Colorado Plateau-Research, Environmental Planning, and Management for Collaborative Conservation
}

\author{
Edited by Charles van Riper III, Miguel L. Villarreal, Carena J. van Riper, and Matthew J. Johnson
}

The Colorado Plateau Biennial Conference series continues its tradition of bridging cultural, social, and biophysical research interests, and addressing the needs of scientists and land managers working in a complex geographic area. Like its predecessors, this 10th edition of proceedings brings together a diverse collection of previously unpublished research papers, the majority of which were presented at the 10th Biennial Conference of Research on the Colorado Plateau. The theme of the conference was "Collaborative Conservation in Rapidly Changing Landscapes," and the chapters are broadly aligned under this theme. One recurring research thread in this volume is the linkage that exists among historic, recent and/or potential land-management decisions, ecosystem function, and landscape health. Several chapters examine the impact of past management activities, particularly grazing and fire suppression, on current plant community composition and ecosystem structure. Other chapters present assessments of management tools and concepts (e.g. rapid biological inventories, ecosystem valuation, and landscape connectivity) that have been, or can be, utilized by land managers to conserve, maintain, or restore ecosystem health within changing landscapes of the Colorado Plateau. All of the chapters in this volume focus on illuminating the advantages and challenges of collaborative decision-making for biological and cultural resource conservation. Diverse topics ranging from the impacts of aspen decline on avian diversity to vegetative "soft capping" of exposed archeological ruins have the common endgoal of presenting land managers with new tools for improving stewardship of resources in a time of rapidly changing social and ecological conditions.

In this synthesis, we present a brief distillation of each chapter, highlighting research approaches and key findings. This chapter is organized by the four thematic sections of the book: 1) Reaching towards integration on the Colorado Plateau, 2) Assessing natural and man-made threats to ecological systems, 3) Synergy between human and environmental systems: Planning and management frameworks, and 4) Tools for conservation and collaborative decision-making. This synthesis guides readers through the overarching themes of the book, with the goal of stimulating new research ideas and collaborative efforts while highlighting the continued vitality of the Colorado Plateau Biennial Conference book series.

\section{Section 1: Reaching Towards Integration on the Colorado Plateau}

In Chapter 1, Holcomb et al. examine how federal land management mandates are manifested on the landscape and how collaborative decision making can improve cross-boundary conditions in multijurisdictional landscapes. A number of studies have previously examined the biological and geographical effects of boundaries (Landres et al. 1998, Saunders et al. 1991). There is, however, surprisingly little scientific information describing the effects of administrative boundaries on ecosystems and ecosystem processes on the Colorado Plateau, an area with one of the highest densities of national parks in the United States. In this chapter, titled "Administrative Boundaries and Ecological Divergence: The Divided History and Coordinated Future of Land Management on the Kaibab Plateau, Arizona USA," Holcomb et al. employ a mixed-methods approach to assess the effects of administrative 
boundaries and management policies on forest structure, composition, and wildfire behavior. In the quantitative portion of the study, the authors collected vegetation plot data on either side of the boundary between Grand Canyon National Park (GCNP) and the Kaibab National Forest (KNF), examining the plot data to identify differences in species composition and stand structure. The authors also modeled fire behavior in the study area to predict whether management decisions would influence the potential for active crown fire. In the qualitative portion of the study, the authors identified key issues and concerns regarding coordinated resource management and collaborative decision making by conducting interviews with resource managers, research scientists, and members of environmentaladvocacy groups.

Results from the research presented in Chapter 1 illuminate management-related ecological differences on the Kaibab plateau, with plots located on KNF characterized by greater aspen and less fir dominance than those in GCNP. In addition to compositional differences, fire-behavior models indicated that GCNP had more land area predicted to support active crown fires whereas KNF had more area predicted to burn as surface fires and passive crown fires. The authors suggest that land management, specifically disturbances related to timber harvest and road building, resulted in the higher dominance of aspen on KNF. Discussing the salient points from interviews with resource managers, researchers, and environmental advocates, the authors note a general consensus that greater interagency coordination on the Kaibab Plateau would improve ecological conditions; however, political limitations to such coordination remain.

Chapter 2, titled "Assessment of Mixed Conifer Forest Conditions, North Kaibab Ranger District, Arizona USA" contributes to the scientific literature examining and establishing long-term changes in forest conditions of the southwestern U.S. (Fulé et al. 1997; Vankat et al. 2005; Vankat 2011). The goal of this chapter was to inform forest restoration and fuel-reduction activities by identifying biophysical and environmental factors that contribute to mixed-conifer stand density. To accomplish this goal, Sesnie et al. compared contemporary mixed-conifer forest conditions with historical data from 1909 and analyzed the relationship between environmental gradients, forest composition, and forest structure. Their results suggest major changes in mixed conifer forest conditions after 1909. Tree density and basal area, particularly of shade tolerant species, increased considerably, and forest conditions now appear more homogenous across the landscape. Analyzing contemporary stand data with abiotic environmental data, the authors found that elevation and solar radiation have a greater effect on determining species composition than did stand density. The information presented in this chapter adds to a rich literature describing long-term forest dynamics on the Colorado Plateau.

In Chapter 3, Mork et al. examine the impacts of post-wildfire livestock grazing on ponderosa pine understory communities. Their study is the first to document concurrent effects of both fire and grazing disturbances on these communities of the Colorado Plateau, and they focus their research on post-fire invasions by non-native species. Disturbances such as grazing and wildfire are known to alter ecological conditions in a way that can encourage exotic invasion, and new invaders can quickly alter system dynamics (D’Antonio and Vitousek 1992). This chapter focuses specifically on the effects of grazing and wildfire on the establishment of cheat-grass (Bromus tectorum), a highly flammable invasive annual that, once established, is capable of altering fire regimes and ecosystem processes (Knapp 1996).

Results from a controlled grazing enclosure experiment initiated two years after the Warm Fire on the Kaibab National Forest indicated greater abundance of Bromus tectorum in grazed plots when compared to ungrazed. Although not statistically significant, the enclosure data suggest that long-term grazing following wildfire may encourage the spread of non-native plants, especially introduced grasses. 
These results, while preliminary, encourage further long-term research into the relationship between post-fire grazing and non-native species in ponderosa pine understory.

Chapter 4, "Challenges and Opportunities for Ecosystem Services and Policy in Arid and SemiArid Environments," closes the first section of the book. This chapter by Bagstad et al. presents challenges that face the Colorado Plateau in applying the ecosystem-services concept to decision making. The three central postulates of this chapter are that: 1) temporal and spatial distribution of water drives ecosystem services on the Colorado Plateau; 2) the location of human beneficiaries matters greatly in the perceived value of an ecosystem service; and, 3) low human population densities over the Plateau lower the perceived value of ecosystem services in general.

The chapter focuses on water as a driver of ecosystem services on the Colorado Plateau, as it is the primary limiting resource in arid and semiarid ecosystems and controls the rates and the timing of biological processes in dryland species. In addition to riparian and spring systems, the authors discuss the Colorado Plateau uplands, which provide a range of important ecosystem services including carbon sequestration and storage, dust and sediment regulation, and forage provision (Miller et al. 2011). The chapter also examines the importance of watershed and airshed position as related to ecosystem services. On the Colorado Plateau, researchers and managers increasingly recognize the importance of accounting for the supply and demand of ecosystem services and their spatial and temporal flow patterns in preparing rigorous assessments of managed landscapes. The flow of surface and groundwater carries benefits toward human recipients far from the Plateau, reaching as far west as California and south into Mexico. The arrangement of water users and supplies in the Southwest has evolved dramatically over the last century and is likely to continue to do so in the future.

This final chapter ends with an in-depth discussion of the implications of ecosystem services for science and policy in the southwest. The authors discuss the difficulty of linking water quantity, quality, location, and timing to ecosystem service provision, watershed position, and long-distance beneficiary flows, which partially explains why an ecosystem services approach to date has failed to impact watershed management decisions on a meaningful level. They also point out that further evolution of science and policy is needed to bring ecosystem services into decision making on the Colorado Plateau. Continued development of the ecosystem services field will allow managers and scientists to improve resource-management tools and policies in the future.

\section{Section 2: Assessing Natural and Man-Made Threats to Ecological Systems}

In Chapter 5, Floyd et al. present results of research at six long-term monitoring sites in Chaco Culture National Historic Park, where they compared the consequences of past grazing regimes on plant species richness, cover of biological soil crusts, shrub density, vegetative cover, and plant community composition. Livestock grazing has long been held to have serious ecological consequences in the arid Southwest and may become even more problematic with global climate change projections of warmer and more arid conditions (Garfin et al. 2010). The authors examined the conditions of two grazing exclosures, one that was fenced in the 1930s and another in the 1990s, such that long-term protection ( $>60$ years of exclosure), recent protection ( $\leq 12$ years), and current grazing treatments were immediately adjacent at six sites. They found that plant community structure reestablished differentially with protection from grazing depending on the inherent biotic potential of each site (e.g. variability of soil quality). The greatest differences between surveys were in forb characteristics, although much of this was related to the amount of precipitation the site received prior to the recent survey.

In areas of long-term protected treatments, signs of recovery included the abundance of biological soil crust and plant biodiversity, and plant species richness and total cover was greater under long-term protection at all six sites. Depending on soil substrate, some sites had higher shrub recovery 
while others experienced increases in grasses. Information on signs of biological soil crust recovery, important for stabilizing soils and mitigating dust in arid ecosystems, and the variable vegetation trends presented in this chapter can be used to guide management decisions on grazing and restoration on the Colorado Plateau.

In Chapter 6, Bombaci and Korb report the effects of sudden aspen decline (SAD) on avian species composition in southwest Colorado Plateau forests. This is a timely chapter, in that Worrall et al. (2008) found that aspen (Populus tremuloides) forests in southwestern Colorado have experienced the greatest SAD-related declines in the region, losing over 10 percent of total aspen cover. Compounding this loss is the fact that aspen regeneration typically occurs vegetatively after a disturbance via a clonal root system (Schier et al. 1985) and SAD loss is characterized by a lack of suckering growth beneath declining aspen stands.

Aspen habitat is considered one of the most biologically diverse ecosystems in the west (Kay 1997), and it is especially important for birds (Robbins et al. 1986). In this chapter, the authors conducted an assessment of changes in avian species composition and biodiversity associated with SAD on the Colorado Plateau with a goal of providing a measure of preliminary changes within aspen ecosystems to establish a basis for long-term monitoring of SAD-related avian community changes. Given the relationship between habitat quality and species diversity, they hypothesized that there would be lower avian biodiversity in SAD-affected stands when compared to healthy stands.

After measuring vegetation structure at avian count stations on the Dolores Ranger District of the San Juan National Forest, the authors found some unexpected results. Differences were detected in both overstory and understory vegetation structure among low, moderate, and high SAD stands, and many of the observed differences were responses to increased aspen mortality. However, contrary to their hypothesis, avian biodiversity was greater in high SAD areas, as indicated by associated higher mean species richness and diversity values. The authors suggest that significantly greater biodiversity values found in high SAD stands may indicate that certain avian species are responding to the newlyavailable niches provided by changes in vegetation structure associated with SAD. Hole-nesting species had consistently higher numbers in SAD stands, possibly the result of more dead trees that provide greater numbers of nesting cavities. This chapter provides a solid foundation of information on differences in avian species composition, abundance, and biodiversity associated with SAD in southwest Colorado, providing insight into responses of forest-bird communities to future SAD disturbances. Furthermore, given the future likelihood of prolonged and climate-induced drought in western North America (Garfin et al. 2010), and the relationship between SAD and drought (Johnson et al. 2008), this research provides crucial insight into responses of forest-bird communities to future SAD disturbances under climate change.

Chapter 7, by van Riper and Crow, also addresses avian responses to habitat change, shifting the focus to pinyon-juniper vegetation. The authors investigated relationships between birds and vegetation in fuels-reduction treatment areas within pinyon-juniper woodlands over the Colorado Plateau. Their goal was to document differences in obligate bird communities to chained versus hand-cut pinyonjuniper fuels-reduction treatments, relative to undisturbed control sites. They selected 73 study plots in southern Utah and northern Arizona, of which 33 had been previously thinned by hand cutting or chaining, and 40 control sites in untreated pinyon-juniper woodlands. At the 73 locations, they documented vegetation structure and counted birds during the 2005 and 2006 breeding seasons utilizing the variable circular plot technique (Reynolds et al. 1980). Results indicated that the density of pinyon pines was the most important variable in predicting bird species richness at all sites. Within treatments, chaining resulted in significantly fewer birds and decreased species richness, while there was no difference between selective cutting and control sites. Initially, study areas with selective hand cutting 
had reduced numbers of birds, but within several years, these sites supported greater bird numbers than non-treatment control sites.

For the 16 pinyon-juniper obligate bird species examined during this study, the authors found that the abundance of five was positively related to pinyon pine density and two were positively related to juniper density. The five related to pinyon pine are the Black-chinned Hummingbird (Archilochus alexandri), Blue-gray Gnatcatcher (Polioptila caerulea), Black-throated Gray Warbler (Dendroica nigrescens), House Finch (Carpodacus mexicanus) and Western Scrub Jay (Aphelocoma californica); the two related to juniper density are the Bewick's Wren (Thryomanes bewickii) and Brewer's Sparrow (Spizella breweri). These responses, along with other bird-vegetation relationships influenced by treatment type, can be considered by land managers when planning fuel reduction treatments in pinyonjuniper woodland habitat on the Colorado Plateau.

In chapter 8, Stumpf reviews the literature related to predation and parasitism of songbirds and explores how habitat characteristics influence these factors. This chapter specifically focuses on songbirds that are subject to both high rates of predation and parasitism and discusses how bird species may respond differently to characteristics at different scales, especially in southwestern riparian habitats where linear patches may alter predator and/or parasite diversity and abundance. In most cases, smaller overall habitat patches, linear patches with very narrow cross-sections, and habitat patches adjacent to disturbed or agricultural landscapes lead to higher predation rates. Parasitism is especially prevalent in isolated habitat patches adjacent to and near agricultural areas that have active pesticide programs. In the conclusions to this chapter, Stumpf finds that landscape scale characteristics, including patch size and surrounding landscape, are most often associated with nest predation, and that all three spatial scales (landscape, territory, and nest site) are equally likely to be associated with parasitism including patch size, habitat type, and surrounding landscape. She concludes by suggesting that managers seeking to design and implement restoration plans should examine individual patch characteristics as well the surrounding landscape in order to minimize the risk of predation and parasitism to songbirds. Habitat restoration and management of landscapes will benefit from more rigorous, long-term studies incorporating these landscape characteristic measurements, especially in areas that experience high rates of nest predation and parasitism.

\section{Section 3: Synergy Between Human and Environmental Systems-Planning and Management Frameworks}

In Chapter 9, titled "Knowing the Cogs and Wheels: The Utility of Bioblitzes for Conservation," Fertig et al. document the results of a bioblitz in Deer Creek, Utah. A Bioblitz is a biological inventory conducted during a short time period (e.g., 24-48 hours) within a specified area. As a citizen science effort, this kind of event helps to connect the public with biologists, promote interest in nature, and serve as a potential first step in acquiring baseline data on species presence for areas of conservation concern. The idea of assembling teams of taxonomic specialists to quickly establish baseline conditions of biological diversity in threatened habitats took hold in the late 1980s with the development of the Rapid Assessment Program (RAP) by several international conservation groups (Wilson 1992). The Deer Creek bioblitz specifically focused on identifying the number and diversity of species in the area, educating and involving the public, and discovering previously unreported species in the area.

The authors present results from two bioblitzes in July 2007 and May 2008 that occurred in the Deer Creek drainage, an area east of Boulder and adjacent to Grand Staircase-Escalante National Monument and Dixie National Forest, Utah. A team of botanists, bryologists, biologists, entomologists, ecologists, and interested landowners participated in the bioblitzes and documented 588 taxa, including more than two dozen species not previously recorded in the area. Nearly $80 \%$ of the vascular plant and 
vertebrate taxa from the study area were previously documented from other sites in the Deer Creek watershed. Although comparable numbers of species were observed both years, there was nearly $50 \%$ turnover in recorded species from 2007 to 2008. The bioblitzes increased communication among biologists from multiple disciplines as well as demonstrated the high biological significance of the Deer Creek drainage, fostering interest in conservation in the local community.

Chapter 10 is a valuation study of the Verde River watershed in central Arizona. West et al. present findings from the first phase of a larger program of research designed to value ecosystem services provided by the Verde River and its watershed. Drawing on mail-back questionnaires and 35 semi-structured interviews conducted with stakeholders, the authors identified a range of values ascribed to "ecosystem services", which are characteristics and functional processes of the natural environment that provide benefits to sustain and fulfill human life (Costanza et al. 1997). The study explores how select stakeholders and community members view the functions, processes, and services provided by the Verde River Watershed as well as how they connect to and appreciate this landscape. The findings of West et al. establish a baseline understanding of how and why the area is considered to be important.

The results from this chapter illustrate a diversity of values associated with the Verde River as a place of meaning and value, rather than simply a resource for human use. Nearly 500 ways of valuing the river and its watershed are discussed in the study interviews, the most prominent of which was the existence value or intrinsic worth of the watershed. West et al. referred to this ecosystem service as a "cultural" value that reflected the reasons why local residents believed this area was important (Millennium Ecosystem Assessment 2003). This chapter identifies what people believe contribute to quality of life and elucidates societal connections with important natural resource conditions in the southwest.

Future research can look to this study for guidance on what residents and visitors believe to be the most salient areas of management concern. For example, stakeholders expressed concern over environmental impacts and threats to the future health of the watershed, including water depletion, human development, invasive species, and climate change. In addition to providing a foundation for future research, the issues highlighted in this study will inform educational efforts and help ensure land managers are receptive to public interests. In Chapter 11, Lim et al. present ongoing laboratory and field research at Mesa Verde National Park, utilizing the archeological ruins at Far View House to address the question of how best to protect exposed masonry walls from environmental stresses. Exposed ruin walls at archeological sites on the Colorado Plateau are typically protected from water (in all its forms) and invasive vegetation by the application of "hard caps" of lime, amended soils and lime, or cement mortars (Ashurst 2007). These hard caps fail when cracks develop and water flows into the walls; this seepage, along with temperature differences, can ultimately lead to masonry collapse. The repeated repairs needed to maintain hard caps have been inadequate in the long-term management of ruins. In order to best conserve and manage archaeological structures, the authors argue that managers need to understand the sources and effects of environmental factors and then identify remedial and preventive conservation methods to minimize their damaging impacts upon features and sites.

The authors explore the usefulness of "soft capping," a procedure introduced in recent years at several archaeological sites in England and Turkey (Wood 2005). Soft capping replaces hard caps with vegetation planted on top of a layer of soil, with optional layers of gravel, and sometimes geosynthetics (Matero et al. 2008). The authors present information where they compare methods for the protection of the wall tops and the prevention of water penetration into the wall core, utilizing two types of caps that were installed on top of a test wall: 1) a hard mortar and stone cap based on the Park's current methods of stabilization; and 2) an experimental soft vegetative cap. Temperature and moisture probes were 
installed in the wall masonry and surrounding ground/fill in order to monitor and evaluate the performance of each cap.

The comparison between the soft- and hard-cap temperature regime demonstrated the soft cap's ability to dampen temperature fluctuation within the wall. The soft caps were more robust and kept in less moisture because they dry faster due to exposure. The authors conclude that a soft cap should perform very well in dry climates with concentrated precipitation events, like that at Mesa Verde. Considered in combination with water-susceptible materials such as soil-based mortars, soft caps appear to be a far better solution to the problem of wall protection in the arid Southwest than hard caps. A second finding from this study shows the need to understand how water moves through the wall system, especially as it is influenced by grade and associated fill. They demonstrate that moisture uptake by the wall from the adjacent soil occurs for an extended period of time, especially as snow melts. This has direct implication on selecting and integrating preservation methods. They conclude this chapter with recommendations for future preservation activities including monitoring and assessment, and close with a discussion about soft capping as an attractive alternative to hard caps for archeological preservation.

Chapter 12 explores two competing subwatershed plans that were developed for an urbanizing area in the Town of Oakville, Ontario. Eagles et al. examine mapping schemes associated with these two plans, one designed by the Town's urban planners and the other by the area's land owners. Both groups developed their plans independently, but were given a special focus on ecological cores and linkages (e.g., Environmentally Sensitive Areas) to be protected from development. The similarities and differences in the two designs point to different methods and philosophies that underpinned the two groups in their planning process. The authors explore the differing interpretations in light of the politics of the planning process specifically related to negotiation and power dynamics within each group. In the Oakville case, more green space was set aside by the Town's team of urban planners and this conservative plan was adopted as a template for development prior to any conflict resolution undertaken by the participating parties. Most of the subsequent negotiations with representatives for the group of land owners occurred "behind closed doors." The authors explore the limitations of applying landscape connectivity literature to land use planning in urban areas and these findings should prove useful to managers on the Colorado Plateau.

Chapter 13, "Recovering endangered fish in the San Juan River using adaptive management" by Mark McKinstry, discusses the implementation of the San Juan River Basin Recovery Implementation Program (SJRIP). The SJRIP was begun in 1992 and authorized by Congress in 2000 to protect and recover endangered fishes (Colorado pikeminnow and razorback sucker) while allowing water development to proceed. The SJRIP is coordinated by the U.S. Fish and Wildlife Service and the Bureau of Reclamation, with the aim of using adaptive management to assist in the recovery of these fish species. The SJRIP program is a nationally recognized effort that has served as a model to address other Endangered Species Act issues throughout the country. McKinstry describes how the overall program works, defines the goals and objectives of the program, and details the responsibilities of the participants. The author explains the aggressive efforts that are being implemented through program elements and comprehensive plans to: construct fish passages, fish screens, and propagation facilities; restore and enhance aquatic habitat; improve water use efficiency; stock native fish and control nonnative fish species; and conduct hydrologic evaluations that allow the adoption of natural-flow mimicry. This chapter highlights management activities under this program and how they are formulated in an adaptive management framework whereby specific actions are conducted, with subsequent monitoring of the fish and habitat used to inform and modify future activities. This adaptive management approach has allowed the SJRIP to make progress towards recovery in the face of uncertainty about various aspects of the biology and ecology of these endangered species. 


\section{Section 4: Tools for Conservation and Collaborative Decision-Making}

In Chapter 14, Poff et al. employ statistical modeling techniques and Geographic Information Systems (GIS) to forecast changes in forest conditions based on multiple (and sometimes conflicting) management preferences and goals. Spatial modeling exercises that provide multiple potential outcomes are becoming indispensable tools for collaborative and comprehensive environmental planning processes (Sheppard and Meitner 2005). The modeling process employed in this study, called MultiObjective Decision Making (MODM) fosters collaborative decision-making by identifying a compromise point between competing goals and preferences of multiple land managers.

In this study, members of the Mogollon Rim Ranger District Interdisciplinary Team were asked to identify ideal forest conditions based on their areas of expertise and management agendas, which included wildfire, weed control, silviculture, and wildlife habitat management. When coupled with GIS analyses and spatial data, managers' preferences, measured and modeled in terms of stand density, were visualized both over the landscape and into the future. Information garnered from the MODM exercise can help managers with competing agendas identify a compromise position and, when acted upon, allows for a more transparent decision making process.

In Chapter 15, Dreesen et al. present a number of novel planting techniques for stream restoration that aim to increase plant establishment and survival rates. Many riparian areas throughout the southwestern United States have undergone considerable changes over the past century due to human land uses and climatic changes (Webb et al. 2007). The deep-planting methods described in the paper are novel in that they maximize the use of existing soil moisture reservoirs and minimize or eliminate the need for irrigation. The authors argue that riparian plants favor a deep-planting, root-burial type of planting technique because it mimics the effects of post-flooding sediment dynamics common to riparian systems.

The authors found that by deep-planting a long pole cutting directly into the capillary fringe many replanted phreatophytes can expect a $90 \%$ survival rate. For upland species, the entire root crown is deep-planted into the capillary fringe; however the upland plants typically require more irrigation and maintenance than pole-cut phreatophytes. Upland plant survival rates varied between $70-90 \%$, with most of the mortality related to long-term root inundation during wet periods, and failure to properly irrigate following water table decline. The chapter provides sound guidance for ecologists and land managers seeking to enhance or restore degraded riparian zones and river channels, areas of particular importance for maintaining regional biodiversity and habitat connectivity.

\section{Section 5: A 20-Year Evaluation of the Colorado Plateau Biennial Conference}

The book closes with a chapter by Lee et al. that offers insight into the perceived value of the Biennial Conference of Research on the Colorado Plateau (COPL) among attendees. The authors conducted a series of evaluations from participants who attended the 2009 10th COPL conference to determine whether attendees believed the organizers' goal of scientific integration was attained through conference participation. Using an on-line survey of participants, Lee et al. examine the programmatic components (e.g., conference programming, networking opportunities, and additional activities) of the meeting and descriptively analyzed how social networks were developed and/or social capital was built among attendees. This analytic approach allowed the authors to examine the perceived importance and satisfaction of various aspects of the meeting, while documenting the ways in which the conference helped to form relationships among scientists, managers and students.

The study findings suggest that after 20 years, the COPL meetings have brought a suite of professional benefits to conference attendees and can be improved in several important ways. The programmatic components of the Biennial conference are considered to be generally important and 
satisfactory; however, maintaining a reasonable cost and providing opportunities to network with speakers and other conference participants warrants special attention from future conference organizers. The analysis of social capital survey items suggests that interpersonal connections, social cohesion, secondary associations, and perceived utility were relevant dimensions of social networking that shaped the COPL conference experience. These findings detail how the COPL conferences could continue to provide meaningful experiences among attendees. This final chapter maintains a critical perspective on how the 10th Biennial Conference of Research on the Colorado Plateau can be improved so that future hosts and organizers can more efficiently invest their time, energy, and programming.

\section{Abstracts}

ADMINISTRATIVE BOUNDARIES AND ECOLOGICAL DIVERGENCE: THE DIVIDED HISTORY AND COORDINATED FUTURE OF LAND MANAGEMENT ON THE KAIBAB PLATEAU, ARIZONA, USA

Christopher M. Holcomb, Thomas D. Sisk, Brett G. Dickson, Steven E. Sesnie and Ethan N. Aumack

We applied a mixed-methods approach to research interrelated questions concerning ecological divergence and policy coordination across the administrative boundary between Grand Canyon National Park (GCNP) and Kaibab National Forest (KNF) on Arizona's Kaibab Plateau. To assess cumulative ecological changes between jurisdictions, we used field data and spatial models to compare aspen dominance, fir dominance, predicted fire hazard, and predicted fire behavior across these two jurisdictions within a contiguous study area spanning the boundary. Our analyses document abrupt changes in forest composition and structure at the boundary and indicate that aspen dominance is higher on KNF, while fir dominance and the potential for active crown fire is higher in GCNP.

To assess current and potential future approaches to management, we conducted interviews with agency staff, scientists with active research on the Kaibab Plateau, representatives from environmental advocacy organizations, and the principal grazing permittee on the National Forest portion of the Kaibab Plateau. Pressing issues affecting both agencies, including fire management, have stimulated interest in landscape-level planning and management, requiring coordination across the administrative boundary. Interviews captured several recommendations for improving cooperation, in part by identifying and eliminating bureaucratic roadblocks. Most of those interviewed expressed the view that the goals of the two agencies are complementary, and that historical differences in management objectives and approaches have lessened in recent years. We highlight four important recommendations from these interviews that could facilitate increased cooperation at broader spatial scales: (1) ensure consistency in regulations regarding the management of Mexican spotted owls across the administrative boundary; (2) develop and implement a common fire plan that aligns fire management objectives and allows beneficial fires to burn across the administrative boundary; (3) work toward development of a single natural resource plan that covers the entire Kaibab Plateau and directly addresses issues that demand a long-term, broad-scale approach; (4) develop a budget process that will allow the two agencies to jointly fund projects of mutual interest. Implementing these recommendations will require effort, investment, and creativity, but the resulting ecological benefits and budgetary efficiencies could be considerable.

ASSESSMENT OF MIXED CONIFER FOREST CONDITIONS, NORTH KAIBAB RANGER DISTRICT, KAIBAB NATIONAL FOREST, ARIZONA, USA

Steven E. Sesnie, Brett G. Dickson, Jill M. Rundall and Thomas D. Sisk

Southwest mixed conifer forest types maintain a diversity of tree species and structural conditions that contribute to desirable ecosystem services (e.g., higher biodiversity, watershed 
protection, forest carbon pools and aesthetic values). Less is known about mixed conifer forest and historical changes in composition and structure than for other Southwest forest types such as ponderosa pine. The U.S. Forest Service 2009 Kaibab Forest Health Focus initiative identified mixed conifer forest as a priority vegetation type requiring active forest restoration and hazardous fuel reduction in light of recent and severe fire activity. We evaluated contemporary changes in mixed conifer forest conditions on the North Kaibab Ranger District (NKRD) of Kaibab National Forest north of Grand Canyon National Park (GCNP), where other recent studies and historical forest inventories provided an excellent opportunity for comparative analyses. Inventory data from 1909, 1955 and the 1990s on the NKRD showed that average basal area had doubled by 1955. Basal area in 1990 was also double that of 1909, but had decreased by $28 \%$, for trees $\geq 30 \mathrm{~cm}$ in diameter since 1955 . Tree density for shade-tolerant species such as spruce and true fir showed a $>600 \%$ increase between 1909 and 1990, whereas ponderosa pine showed little increase. Inventory data indicated a pattern of high basal area accretion prior to 1955 as fire was excluded from MC forest and increased tree recruitment of shade tolerant species following selective logging and insect caused tree mortality during the1970s and 80s. Separate analyses of elevation and annual solar radiation gradients indicated that tree species composition was significantly different from low to high elevation sites in 1990, as was average canopy height. Densities of shade-tolerant trees were high on all sites. Forest structural attributes associated with fire behavior did not differ significantly across gradients with the exception of relatively mesic sites at high elevations or in shaded areas (i.e., drainages) that showed 18\% greater canopy bulk density and 11\% lower canopy base height. Restoration activities in mixed conifer forest should be focused on reducing a historically high density of shade-tolerant understory trees while providing opportunities for the regeneration of fire-adapted species, such as ponderosa pine and Douglas fir. Tree thinning and burning activities should seek to restore mixed severity fire regimes that historically maintained tree species and structural diversity, while reducing overall hazardous fuel accumulations that have developed for most site conditions in the absence of fire.

LIVESTOCK GRAZING FOLLOWING WILDFIRE: UNDERSTORY COMMUNITY RESPONSE IN AN UPLAND PONDEROSA PINE FOREST.

Lauren A. Mork, Thomas D. Sisk and Ethan N. Aumack

Livestock grazing occurs across extensive tracts of western National Forest lands. Meanwhile, wildfire in western forests is increasing in frequency and severity, changing the ecological context within which grazing occurs. Although disturbance is known to regulate plant community organization, the effects of interactions between fire and ungulate herbivory in herbaceous understory forest communities remain poorly understood. To our knowledge, no prior experiment has addressed the interaction of livestock grazing and fire on ponderosa pine understory communities in the Southwest. We examined the hypotheses that livestock grazing following wildfire 1) alters relative plant species abundance and 2) increases incidence of the invasive exotic Bromus tectorum. We conducted a replicated landscape-scale grazing enclosure experiment within an extensive wildfire burn on the Kaibab Plateau north of Grand Canyon, AZ. One significant pattern and several important community trends emerged: 1) Grass cover decreased by $2 \%$ in grazed plots, but increased by $19 \%$ in ungrazed plots one growing season after grazing, resulting in a significantly greater difference between grazed and ungrazed plots one year after grazing in 2009 than prior to grazing in 2008. 2) Non-native herbaceous cover increased by $13 \%$ in grazed plots while decreasing by $6 \%$ in ungrazed plots in 2009 . 3 ) Cheatgrass occurrence increased in both grazed and ungrazed plots in 2009, and increased at almost twice the rate in grazed plots as compared to ungrazed plots. While the latter two findings were not statistically significant during the initial period of this experiment, they may nonetheless prove to be 
biologically meaningful and may have important implications for future understory composition. Results from this ongoing experiment strongly emphasize the need for long-term field experiments that will provide a scientific basis for post-fire grazing management and advance conservation of native plant diversity in western forest ecosystems.

Keywords: cheatgrass, Bromus tectorum, non-native species, fire, disturbance, range management, ungulate, herbivory.

ECOSYSTEM SERVICES SCIENCE AND POLICY IN ARID AND SEMIARID ENVIRONMENTS: OPPORTUNITIES AND CHALLENGES FOR THE COLORADO PLATEAU

Kenneth J. Bagstad, Darius J. Semmens, and Charles van Riper III

Ecosystem services - the economic benefits that nature provides to people - are gaining recognition in the research and policy communities as a means of better supporting sustainable resource management. Yet for arid and semiarid environments, including the Colorado Plateau, research and application of ecosystem services concepts has lagged behind the more populous temperate, humid, and coastal regions. Here we explore three important issues for the Colorado Plateau research and policy communities related to the ecology, economics, and geography of ecosystem services. These include: 1) the critical importance of the temporal and spatial distribution of water in supporting the ecosystems that provide these services, 2) how the location of human beneficiaries within watersheds and airsheds affects the value attributable to the ecosystem service, and 3) how low population densities contribute to long distances between beneficiaries and the ecosystems providing key services, which can reduce public perceptions of the value of these ecosystems. We elaborate on these three issues, citing examples from the Colorado Plateau and other parts of the Intermountain West, along with science and policy implications. While ecosystem services research and application toward policy are at a nascent stage on the Colorado Plateau, increased attention to these issues can advance the research agenda and identify barriers and opportunities for applying ecosystem services to decision making as this field continues to advance.

\section{REVISITING TRENDS IN VEGETATION RECOVERY FOLLOWING PROTECTION FROM} GRAZING, CHACO CULTURE NATIONAL HISTORIC PARK, NEW MEXICO

\section{Lisa Floyd, David D. Hanna, Thomas L. Fleischner and Brad Shattuck}

Livestock grazing has serious ecological consequences in the arid Southwest, leading to management dilemmas that become more problematic with global climate change projections. Management challenges can be illuminated by long-term monitoring studies, especially under varying climatic conditions. We revisited sites in Chaco Culture National Historic Park, where we had previously analyzed historic livestock grazing impacts under drought conditions (1999-2000). Two ages of grazing exclosures were created by fencing projects in the 1930s and 1990s, such that long-term protection ( $>60$ years of exclosure), recent protection ( $\leq 12$ years), and current grazing treatments were immediately adjacent at six sites. We compared plant species richness, cover of biological soil crusts, shrub density, vegetative cover, and plant community composition at these six sites. Our recent resurvey (2006) took place during a period of higher summer precipitation and temperature. The greatest differences between surveys were in forb characteristics. In all grazing treatments, forb density and cover was higher during the wetter season than during drought, and 77 forb species were recorded that had not been present in our earlier surveys (Floyd et al. 2003). Plant species richness continued to be significantly greater under long-term protection at all six sites. No differences among treatments in invasive plant diversity or cover were detected. The cover of black biological soil crusts was significantly higher under long-term protection at three of the four sites monitored; in the fourth, cover 
was highest under short-term protection. On Menefee Shales at Kin Klizhin, crust cover was six times higher with long-term protection than where currently grazed. These results affirm our earlier assertion that recovery of soil crusts can proceed rapidly with protection from grazing. Post-grazing trends were variable at the six sites with Fajada Gap (a grassland) having a significantly greater shrub density and cover in the currently grazed treatment than under protection. In contrast, at Mockingbird Mesa-top (a low shrubland) there was a significantly greater shrub density and cover in protected treatments. Thus plant community structure re-established itself differentially with protection from grazing depending on the inherent biotic potential of each site. This variable trend is an important management consideration.

\section{THE EFFECTS OF SUDDEN ASPEN DECLINE ON AVIAN SPECIES COMPOSITION AND BIODIVERSITY IN SOUTHWESTERN COLORADO}

\section{Sara P. Bombaci and Julie E. Korb}

Aspen (Populus tremuloides) stands in southwestern Colorado have recently experienced sudden aspen decline (SAD), which is a unique form of large-scale aspen mortality associated with the rapid loss of entire aspen stands. Aspen forests are biologically diverse, and a comparatively high diversity and abundance of birds are associated with aspen habitat. Yet, studies have not yet evaluated avian community changes associated with SAD-affected aspen forests. Therefore, from early June to early July 2009, we conducted avian surveys and evaluated stand structure and forest understory in aspen stands located in the Dolores Ranger District of the San Juan National Forest. We classified different SAD levels that included: 1) low SAD (0-29\%), 2) moderate SAD (30-70\%), and 3) high SAD (71$100 \%$ ). We used ordination analysis to compare avian species composition and abundance among different SAD levels, measured species richness and diversity, and performed an indicator species analysis to determine species that were particular indicators for different SAD levels. Patterns in the avian community produced good discrimination in ordination analysis between low and high SAD stands. Avian species richness was greater in stands with high SAD than in stands with low SAD, and the diversity indices were greater in stands with both moderate and high SAD than in low SAD stands. There was a greater number ( 4 of 5) of indicator species identified for the high SAD category. Our data suggests that the initial changes in avian community structure associated with SAD are distinct between aspen forest with low and high SAD, and that stands experiencing high SAD support avian biodiversity.

\section{AVIAN COMMUNITY RESPONSES TO VEGETATION STRUCTURE WITHIN CHAINED AND HAND-CUT PINYON-JUNIPER WOODLANDS ON THE COLORADO PLATEAU Charles van Riper III and Claire Crow}

We investigated relationships between birds and vegetation characteristics in fuels-reduction treatment areas within pinyon-juniper woodlands over the Colorado Plateau. The goal of this study was to document differences in avian community responses to two types of pinyon-juniper fuels-reduction treatments (chained vs. hand-cutting), relative to undisturbed control sites. We selected 73 vegetation plots in southern Utah and northern Arizona, of which 33 had been previously thinned by hand-cutting or chaining, and 40 control plots in untreated pinyon-juniper woodlands. At the 73 locations we documented vegetation structure and counted birds within 3.1 ha circular plots during the 2005 and 2006 breeding seasons, then with more intensive surveys at the Arizona site from 2007 through 2011. We focused in particular on the effects of fuels-reduction treatments to 16 bird species that are considered pinyon-juniper obligates.

We found that density of pinyon pines was the most important variable in predicting bird species richness at all sites. Within treatments, chaining resulted in significantly less birds and decreased species richness, while there was no difference between selective cutting and control sites. Initially, study areas 
with selective hand cutting had reduced numbers of birds, but within several years these sites actually contained greater bird numbers than non-treatment control sites. Abundance of Brewer's Sparrow (Spizella breweri) was negatively related to chained, but positively related to hand cut areas. Vesper Sparrow (Pooecetes gramineus) abundance was negatively related to both chaining and hand-cutting.

Within 16 pinyon-juniper obligate bird species, abundance of five (Black-chinned Hummingbird Archilochus alexandri, Blue-gray Gnatcatcher Polioptila caerulea, Black-throated Gray Warbler Dendroica nigrescens, House Finch (Carpodacus mexicanus, Western Scrub Jay Aphelocoma californica) was positively related to pinyon pine density, while two (Bewick's Wren, Thryomanes bewickii, and Brewer's Sparrow) were positively related to juniper density. These responses, along with other bird-vegetation relationships influenced by treatment type, can be considered by land managers when planning fuels reduction treatments in pinyon-juniper woodland habitat on the Colorado Plateau. Keywords: Colorado Plateau, birds, vegetation structure, pinyon-juniper woodlands, mechanical fuels reduction, chaining, hand-cut, Grand Staircase Escalante National Monument, Walnut Canyon National Monument, Coconino National Forest, Zion National Park

\section{LANDSCAPE SCALE FEATURES PREDICT PREDATION AND PARASITISM ON PASSERINE NESTS: A LITERATURE REVIEW}

\section{Katie J. Stumpf}

Loss and degradation of breeding habitat may force breeding birds to nest in habitats with suboptimal habitat characteristics, exposing them to unnaturally high rates of nest predation and brood parasitism. Species may respond differently to characteristics at different scales, especially in riparian habitats where linear patches may alter predator and/or parasite diversity and abundance. I reviewed the literature to understand how habitat characteristics affect predation and parasitism, because habitat modifications may be a cost-effective method of reducing these pressures. Landscape scale characteristics, including patch size and surrounding landscape were most often associated with nest predation. Factors at all three spatial scales (landscape, territory, and nest site) were equally likely to be associated with parasitism including surrounding patch size, habitat type, surrounding landscape, canopy cover, distance from the nest to the nearest tree, ground cover, tree size, and foliage density. The importance of landscape scale characteristics for predation and parasitism rates may be driven by the effect of large-scale features on abundance and distribution patterns of predators and parasites.

Alternatively, an association between smaller spatial scales and parasitism but not predation may reflect the fact that cowbirds rely mainly on visual cues to locate nests, while a diverse suite of predators may mask any association with characteristics at these smaller scales. Given the importance of patch size for both predation and parasitism, I recommend that future studies carefully quantify predation and parasitism effects across a range of patch sizes to elucidate the patch sizes at which these rates are most strongly reduced.

Keywords: spatial scale, habitat characteristics, riparian, breeding bird ecology, Southwest.

\section{KNOWING THE COGS AND WHEELS: USING BIOBLITZ METHODS TO RAPIDLY ASSESS FLORAS AND FAUNAS \\ Walter Fertig, , Linda Whitham and John Spence}

Although protecting representative examples of the full array of native species is the objective of many conservation projects, circumstances often dictate that actions be taken before the biodiversity of a site is well documented. Such an approach can be inefficient, as some sites may contribute few new species to the protected area network, while other lands with high species richness or complementarity are bypassed. Bioblitzes are a potential first step in acquiring species presence information for an area of 
potential conservation interest. Conducted by teams of taxonomic experts and interested members of the public, bioblitzes are intensive 24-48 hour surveys of the entire biota (plants, vertebrates, invertebrates) of a specific area with the goal of documenting as many species as possible. In July 2007 and May 2008, The Utah Nature Conservancy sponsored two bioblitzes in the Deer Creek drainage, east of Boulder, Utah and adjacent to Grand Staircase-Escalante National Monument and Dixie National Forest. A team of agency and university botanists, bryologists, biologists, entomologists, ecologists, and interested landowners participated in the bioblitz and documented 588 taxa in the area and discovered more than two dozen significant new distribution records. Although comparable numbers of species were observed each year, there was nearly $50 \%$ turnover in recorded species in the second year. Nearly $80 \%$ of the vascular plant and vertebrate taxa from the study area were previously known from other sites in the Deer Creek watershed. The bioblitzes demonstrated the high biological significance of the Deer Creek area and fostered increased interest in conservation in the local community and communication among biologists from multiple disciplines.

Keywords: biodiversity blitz, TNC, Grand Staircase-Escalante National Monument, Utah

\section{VALUING THE VERDE RIVER WATERSHED: AN ASSESSMENT}

Patricia West, Dean Howard Smith and William Auberle

This valuation study is designed to be the first phase of a larger series of studies to value the ecosystem services of the Verde River and its watershed. Interviews were conducted with 35 anonymous community leaders who live in, work with, or manage some aspect of the watershed (or a combination of the three). The interviews resulted in a large list of values for the watershed and provide a starting point for more studies. This report includes preliminary analysis of the data collected from these interviews, a brief literature review on ecosystem services, and recommendations for future research.

This study found that the most valued aspect of the river is not as a place to get things from, but as an entity that is valued for its very existence for a wide variety of reasons, most of which are categorized as "cultural" using the Millennium Ecosystem Assessment (2003, 2005 a-e) criteria. These cultural values contribute to the quality of life of residents of the area and the entire State of Arizona, as well as visitors who provide the area with much of its economic base.

Keywords: Contingent valuation, ecosystem values, ecosystem services, Verde Valley, Prescott, Camp Verde, Cottonwood, Riparian values

\section{VEGETATIVE CAPPING OF ARCHAEOLOGICAL MASONRY WALLS: A TEST AT MESA VERDE NATIONAL PARK}

\section{Alex B. Lim, Frank G. Matero, and Michael Henry}

Exposed ruin walls are typically protected from water in all its forms and invasive vegetation by hard caps of lime, amended soils and lime/cement mortars with or without additional masonry. These "hard" caps often fail when cracks develop and can ultimately lead to masonry collapse. The repeated repairs needed to maintain hard caps have been inadequate in the long term management of ruin sites as they are remedial and often hide and exacerbate water-related damage through entrapment, dissolution, along with ice and salt crystallization. "Soft" capping by utilizing vegetation, soil, gavel, or geosynthetics offers an effective, light-weight, and sustainable alternative to traditional hard capping. This paper presents ongoing laboratory and field research at Far View House, Mesa Verde National Park, that addresses the question of how best to protect exposed masonry walls from environmental stresses, and to offer archeological preservation an attractive alternative to hard caps. 
Keywords: Archaeological Wall Capping, Masonry Stabilization, Moisture Control, Cultural Resource Management, Green Roof, Mesa Verde National Park, Colorado

\section{MOVING FROM LANDSCAPE CONNECTIVITY THEORY TO LAND USE PLANNING: URBAN} PLANNING IN OAKVILLE, ONTARIO

Paul F. J. Eagles, Elke Meyfarth O'Hara and Graham Whitelaw

The Provincial Policy Statement published under the Ontario Planning Act states that "The diversity and connectivity of natural features in an area, and the long-term ecological function and biodiversity of natural heritage systems, should be maintained, restored or, where possible, improved, recognizing linkages between and among natural heritage features and areas, surface water features and ground water features. " Municipal planning must be consistent with this Policy. The Town of Oakville proposed development in a very large area covering 3,000 hectares of farmland, woodland and wetlands. Two planning teams, one working for the Town and one for the area's land owners, developed competing subwatershed plans for the area, with cores and ecological linkages as a major component. The two teams presented maps of cores and corridors to be protected from development, with similarities but some important differences in the linkage design. The paper outlines the similarities and the differences between the two mapping schemes, with an emphasis on linkages. These are related to both linkage theory and to the power politics involved in land use planning in an urbanizing area. Generally, the Town proposed much more land to be reserved as green space, compared to the landowners. All plans were prepared for defence in a hearing in front of the Ontario Municipal Board, an administrative tribunal dealing with land use matters under dispute. However, negotiation between the parties resulted in the Town's plan being accepted as the template for development. The conflicting positions were never fully explored in the tribunal room. Our paper explores the limitations that the linkage literature has for land use planning within urbanizing areas.

Keywords: land use planning, linkages, connectivity, policy, cores, corridors, natural heritage systems, Ontario.

\section{RECOVERING ENDANGERED FISH IN THE SAN JUAN RIVER USING ADAPTIVE MANAGEMENT \\ Mark C. McKinstry}

The San Juan River Basin is the second largest of the three sub-basins that comprise the Upper Colorado River Basin. From its origins in Colorado, the San Juan River flows approximately $560 \mathrm{~km}$ to Lake Powell, intercepted along the way by Navajo Reservoir where the water is stored for use in the San Juan and Rio Grande basins and for delivery to the lower Colorado River Basin. The San Juan River Basin Recovery Implementation Program (SJRIP) was begun in 1992 and authorized by Congress in 2000 to protect and recover endangered fishes (Colorado pikeminnow [Ptychocheilus lucius] and razorback sucker (Xyrauchen texanus]) while allowing water development to proceed. The SJRIP is a nationally recognized effort which has served as a model to address other Endangered Species Act issues throughout the country. Aggressive efforts are being implemented through Program Elements and comprehensive plans to: construct fish passages, fish screens, and propagation facilities; restore and enhance aquatic habitat; improve water use efficiency; stock native fish and control non-native fish species; and conduct hydrologic evaluations that allow the adoption of natural-flow mimicry. Specific tasks to assist in recovering the two fish species are listed in the Program's Long-Range Plan. All activities conducted through the SJRIP are evaluated by two technical committees (Hydrology and Biology) comprised of experts in endangered fish management, fish ecology and biology, geomorphology, hydrology, and habitat management. A Coordination Committee oversees the activities 
of the two technical committees and has responsibility over recovery actions. The Bureau of Reclamation and U.S. Fish and Wildlife Service work cooperatively to carry out the management activities approved by the Program participants. To ensure a scientifically defensible approach to recovery actions, the SJRIP uses standing peer reviewers to evaluate progress of the individual projects and the Program as a whole. Management activities are formulated in an adaptive management framework whereby specific actions are conducted, with subsequent monitoring of the fish and habitat used to inform, and modify, future activities. The adaptive management approach has allowed the SJRIP to make progress towards recovery in the face of uncertainty about various aspects of the biology and ecology of these endangered species. The Department of the Interior recognized the SJRIP and its sister program, the Upper Colorado River Recovery Implementation Program, with a Cooperative Conservation Award in 2008, citing the programs' excellence in conservation through collaboration and partnerships.

Keywords: Colorado pikeminnow, endangered species, razorback sucker, San Juan River Recovery Implementation Program

\section{SPATIO-TEMPORAL MULTI-OBJECTIVE DECISION MAKING IN FOREST MANAGEMENT Boris Poff, Aregai Tecle, Daniel G. Neary and Brian W. Geils}

Forest ecosystem management is the art and science of making decisions that involve numerous cultural, social, economic and environmental components interacting with one another. With many stakeholders involved, it is important that such an inherently multi-objective problem be evaluated using scientifically based methods that are transparent, adaptable and inclusive for all interested parties. The Multi-Objective Decision Making (MODM) process is one such method that was developed in the 1940 s but only has been applied to natural resource management since the late 1990s. We demonstrate the appropriateness and effectiveness of MODM for forest management by creating and comparing future scenarios that incorporate values and priorities from an interdisciplinary management team managing for wildfire, silviculture, wildlife and invasive species. One benefit of MODM is the ability to model forest change with time and space, which is critical since forest ecosystem management analyses are needed at varying spatial and temporal scales. To do this, a conceptual model intended for forest managers and other decision-makers is constructed using one MODM technique, numerous mathematical response functions and two modeling programs - one spatial and one dynamic.

Compromise Programming (CP) is the MODM technique utilized in this ecosystems modeling effort. Twenty-two mathematical response functions that represent major forest management objectives are expressed in terms of one decision variable, forest stand density. An individual-tree growth model (FVS), used by land resources managers to develop silvicultural and land management plans, is used as the dynamic modeling component, while a Geographic Information System (ArcGIS) facilitates the spatial aspect of the modeling effort. With the forest planning software available, it is becoming easy to solve a complex forest management problem in a spatio-temporal MODM framework. In this paper the authors demonstrate how forest managers can identify numerous feasible forest management alternatives in terms of overstory vegetation density management, as well as to what extent the identified management actions achieve the selected objectives over time and space.

Keywords: MODM, Compromise Programming, Forest Management, FVS, GIS

\section{INNOVATIVE PLANTING METHODS FOR THE ARID AND SEMI-ARID SOUTHWEST David R. Dreesen, Gregory A. Fenchel, Danny G. Goodson, and Keith L. White}

The Los Lunas Plant Materials Center has developed several unconventional but effective methods for establishing plants in arid and semi-arid regions of the southwestern US. These methods, 
which are relevant to riparian and upland restoration efforts in the Southwest, are summarized in this paper. For riparian restoration, several deep-planting techniques have proven successful for establishing woody riparian plants by rapidly connecting the root systems of these phreatophytes to the capillary fringe above a shallow water table. These techniques include deep-planting several stock types including long-stem rooted stock, dormant unrooted whip cuttings, and dormant unrooted pole cuttings. On upland xeric sites, woody plants have been established with minimal irrigation by employing long root systems along with embedded watering tubes used to apply water that is slowly released from hydrated hydrophilic starch-based polymers to replenish deep soil moisture. Finally, the key factors influencing the success of native grass seedings are discussed. New methods to enhance native grass establishment are being tested to prolong the availability of shallow soil moisture by using long-lasting organic mulches or hydrophilic starch-based polymers.

\section{REACHING TOWARD THE INTEGRATION OF RESEARCH INTO RESOURCE MANAGEMENT ACTIVITIES: A 20-YEAR EVALUATION OF COLORADO PLATEAU BIENNIAL CONFERENCES}

Martha E. Lee, Carena J. van Riper, Charles van Riper III and Gerald T. Kyle

The Biennial Conferences of Research on the Colorado Plateau serve a critical purpose of connecting management and science in the southwestern US. The primary goal of the conferences has been to create a forum where managers and scientists could come together to learn about and discuss scientific findings to be incorporated in resource management and planning. The purpose of the present study is to assess whether, after 20 years, the conference is still meeting that goal of scientific integration, and ascertain how conference attendees believe the conference is of use, determine what aspects they would like to see retained and/or removed, and examine ways the conference could be improved. An on-line survey was administered to attendees of the 2009 10th Biennial Conference of Research on the Colorado Plateau. We utilize an importance-performance analysis and assess social networking among conference attendees. Results of our analyses show the conference is performing well and attendees are relatively satisfied with the organization, delivery and content of the meeting. Maintaining a reasonable cost and providing opportunities to network with speakers and other attendees are identified as particularly important elements that need to be maintained or enhanced. We found that interpersonal connections, social cohesion, secondary associations, and perceived utility emerged as dimensions of social networking and shaped the relationships formed among conference attendees. We anticipate that the findings of this conference evaluation will help future planners better meet the needs of scientists, managers, administrators, and students.

\section{SUMMARY: INFORMING COLLABORATIVE CONSERVATION AND MANAGEMENT OF COLORADO PLATEAU RESOURCES \\ Miguel L. Villarreal, Charles van Riper III, Carena J. van Riper, Matthew J. Johnson and S. Shane Selleck}

The Colorado Plateau Biennial Conference series continues its tradition of bridging cultural, social, and biophysical research interests, and addressing the needs of scientists and land managers working in a complex geographic area. Like its predecessors, this 10th edition of proceedings brings together a diverse collection of previously unpublished research papers, the majority of which were presented at the 10th Biennial Conference of Research on the Colorado Plateau. The theme of the conference was "Collaborative Conservation in Rapidly Changing Landscapes," and the chapters are broadly aligned under this theme. One recurring research thread in this volume is the linkage that exists among historic, recent and/or potential land-management decisions, ecosystem function, and landscape 
health. Several chapters examine the impact of past management activities, particularly grazing and fire suppression, on current plant community composition and ecosystem structure. Other chapters present assessments of management tools and concepts (e.g. rapid biological inventories, ecosystem valuation, and landscape connectivity) that have been, or can be, utilized by land managers to conserve, maintain, or restore ecosystem health within changing landscapes of the Colorado Plateau. All of the chapters in this volume focus on illuminating the advantages and challenges of collaborative decision-making for biological and cultural resource conservation. Diverse topics ranging from the impacts of aspen decline on avian diversity to vegetative "soft capping" of exposed archeological ruins have the common endgoal of presenting land managers with new tools for improving stewardship of resources in a time of rapidly changing social and ecological conditions.

In this synthesis, we present a brief distillation of each chapter, highlighting research approaches and key findings. This chapter is organized by the four thematic sections of the book: 1) Reaching towards integration on the Colorado Plateau, 2) Assessing natural and man-made threats to ecological systems, 3) Synergy between human and environmental systems: Planning and management frameworks, and 4) Tools for conservation and collaborative decision-making. This synthesis guides readers through the overarching themes of the book, with the goal of stimulating new research ideas and collaborative efforts while highlighting the continued vitality of the Colorado Plateau Biennial Conference book series. 


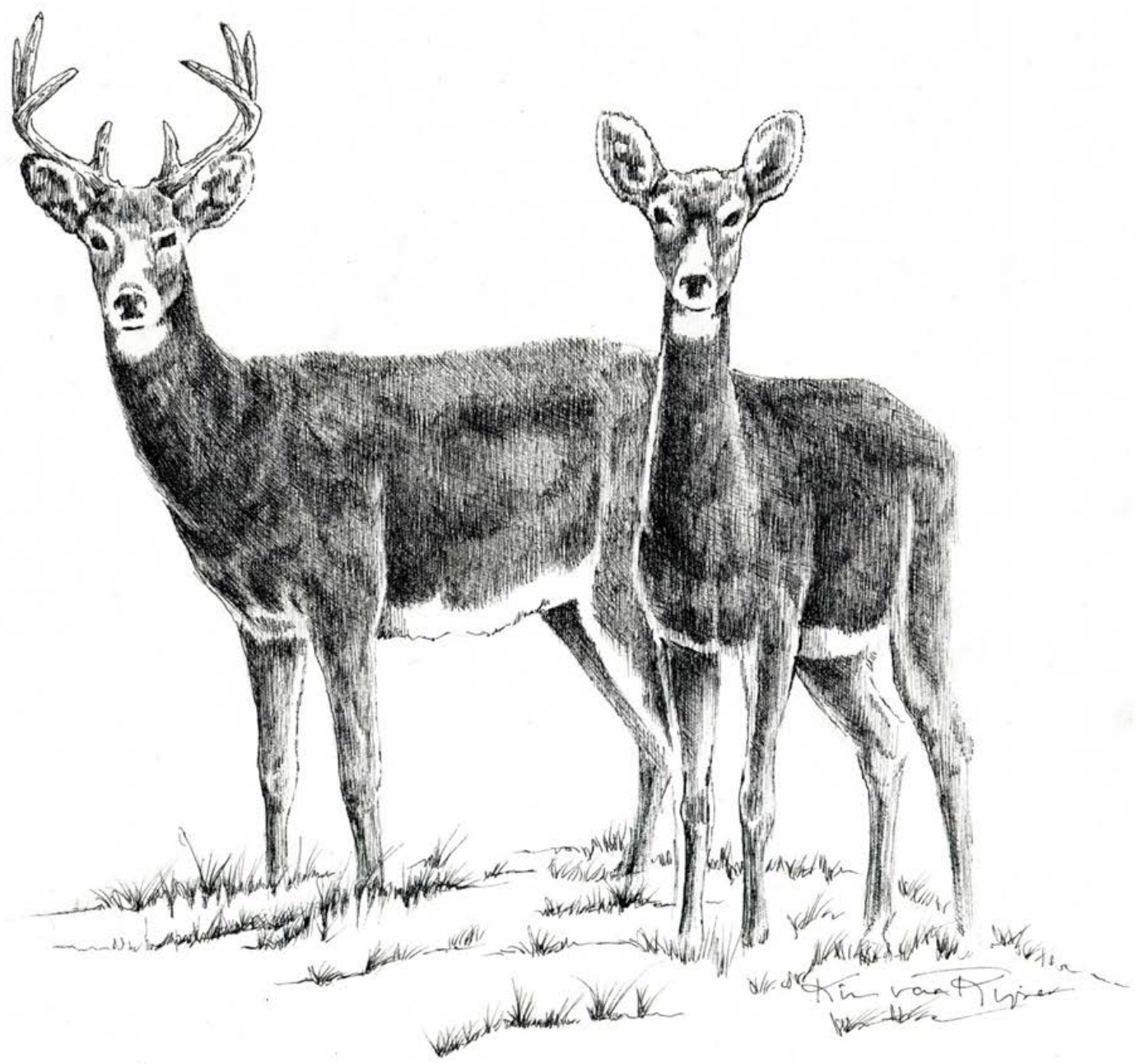

Drawing of Coues whitetailed deer, Odocoileus virginianus (copyright and courtesy of Kimberly Ann van Riper). 


\title{
Proceedings of the Eleventh Biennial Conference of Research on the Colorado Plateau
}

\author{
Edited by Laura F. Huenneke, Charles van Riper III, and Kelley A. Hays-Gilpin
}

[This volume is in press as of 2015; the following are the abstracts from accepted chapters and are shown here unedited as received]

\section{Abstracts}

COLLABORATIVE REHABILITATION OF PAKOON SPRINGS IN GRAND CANYONPARASHANT NATIONAL MONUMENT, ARIZONA

Kelly J. Burke, Kathleen A Harcksen, Lawrence E. Stevens, Robert J. Andress and R. J. Johnson

Pakoon Springs is a complex of about 10 spring sources across 56 ac in a tributary of Grand

Wash within the Grand Canyon-Parashant National Monument, northwestern Arizona. It is one of the largest springs complexes on the Arizona Strip with a total discharge approaching $100 \mathrm{gpm}$. Prior to its purchase by the Bureau of Land Management in 2003, the site was used for a century as a cattle ranch. The BLM and Grand Canyon Wildlands Council, Inc. partnered, with funding from the Arizona Water Protection Fund (AWPF) to inventory the site in 2000-2001, and subsequently cooperated to assess, plan, restore, and monitor the springs from 2006-2010. Planning engaged agency, non-profit, private and tribal partners, providing a broader range of options than any individual effort. Ortho-rectified aerial photography was used to develop a $0.3 \mathrm{~m}$ contour topographic map base for planning as well as mapping vegetation polygons and locations of soil profiles/samples and hydrologic data collection.

Rehabilitation activities included removing abandoned equipment, exposed irrigation pipe, many $\mathrm{km}$ of fencing, dilapidated ranch buildings, and non-native woody plant species (particularly tamarisk), western mosquitofish, American bullfrogs, and a $3 \mathrm{~m}$ American alligator. Geomorphic and vegetation rehabilitation involved recontouring excavated sources and berms, and resetting drainages. In these reconstruction efforts, three habitats were of particular interest: wet meadow (cienega), desert spring-fed stream, and open water.

After replanting local native wetland and riparian vegetation, monitoring results indicated a surprisingly strong recruitment of native plant species. We documented a 5-fold increase in riparian vegetation cover over $3.5 \mathrm{yr}$. Post-treatment bird species totaled nearly two dozen, more than previously observed. The springs also now support a population of western harvest mouse. The first phase of the project has recreated the longest perennial desert stream on the 1.1 million ac monument. A subsequent AWPF grant is supporting enhancement of riparian habitat associated with this stream. Bullfrog removal continues in advance of potential translocation of relict leopard frog (Rana onca).

When aquifers have not been damaged or heavily modified, springs ecosystem geomorphology and habitat rehabilitation can be accomplished. The Pakoon Springs ecosystem has been changed from a highly modified and degraded condition to one in which natural ecosystem processes prevail. This project clearly demonstrates that collaborative partnerships focused on clear, well-defined goals and rigorous implementation and monitoring can be used to improve ecosystem function, sustainability and stewardship, even for highly degraded springs. 
THE VALUE OF FIELD COURSES AND SERVICE-LEARNING PROJECTS TO ENVIRONMENTAL CONSERVATION ON THE COLORADO PLATEAU-A CALL FOR COLLABORATION

Angela B. Moline

The Colorado Plateau provides an ideal setting for field-based conservation courses because it offers a wide range of ecosystem types in a relatively small geographic area. The varied terrain, natural beauty, abundance of public land, and complex environmental and cultural issues provide an excellent setting for experiential field-based courses. Field-based learning offers advantages over classroom learning because students have the opportunity to focus on their studies. It also allows for greater interaction between students and faculty and facilitates authentic service-learning projects in partnership with federal or state agencies, communities, and environmental nonprofit organizations. Service-learning projects and partnerships must benefit both the students and the partner organization; a list of criteria that can be used to evaluate the benefit of projects is described. Field-based servicelearning experiences are a productive and rewarding way to build partnerships that can lead to conservation solutions on the Colorado Plateau, so I encourage land managers and educational institutions to identify and implement mutually beneficial collaborative service-learning projects.

\section{COMMUNITY COLLABORATIONS FOR INCREASING NATIVE SEED AVAILABILITY AND RESEARCH ON THE COLORADO PLATEAU \\ Rachel A. Ostlund, Patricia A. West, and Megan Haidet}

Since its inception in 2001, the Seeds of Success (SOS) program has accessioned over 14,000 collections of native seed from across the United States. SOS is the national native seed collection program, led by the Bureau of Land Management (BLM) in partnership with a variety of federal agencies and non-federal organizations. As the wildland collection arm of the Native Plant Materials Development Program (NPMDP), SOS's mission is to collect wildland native seed for research, development, germplasm conservation, and ecosystem restoration. The long-term conservation goal of the SOS program is to support the NPMDP, whose mission is to increase the quality and quantity of locally adapted native plant materials available for restoring and supporting resilient ecosystems. An ecoregional partnership among the BLM's Colorado Plateau Native Plant Program (CPNPP), SOS and the Northern Arizona Native Seed Alliance (NANSA) has led to more focused efforts to connect management agencies, restoration researchers, and producers of native plant materials (seeds, plugs, or vegetative propagules), as well as guide on-the-ground seed collection, restoration techniques, and longterm storage protocols for these native plants. For the past three years, Northern Arizona University's (NAU) Landsward Institute served as the host institution for SOS interns funded through the CPNPP. SOS banks the first 10,000 seeds of each collection in two locations, dividing them between long-term conservation storage and working collections that may be used for research that promotes native plant materials development. Residual seed may be distributed for a variety of purposes, such as research, education, or seed increase projects. On the Colorado Plateau, knowledge and application of ecotype resiliency, a specific research focus of CPNPP, will be an invaluable restoration tool for the future, as climate change leads to rapid and novel restructuring of plant communities. SOS teams will continue collections in the future and participants in the collaborative CPNPP partnership will continue to guide research.

THE ESCALANTE RIVER WATERSHED PARTNERSHIP: CONSERVATION OF AN ENDANGERED RIPARIAN ECOSYSTEM

John R. Spence and Linda Whitham 
The Escalante River is one of the last free-flowing small rivers in the Intermountain West. The headwaters sources are on Boulder Mountain in southern Utah, where numerous streams eventually unite to form the river, which then flows 150 kilometers to Lake Powell. In addition to a relatively natural hydrograph, the river supports some of the last major stands of endangered Goodding WillowFremont Cottonwood (Populus fremontii-Salix gooddingii) gallery forest on the Colorado Plateau. The river is also home to five native fish species, three of which are protected through a conservation agreement with the State of Utah. Using funding provided by the National Park Foundation, in June of 2009 a group of agency and NGO biologists and local businesses and landowners met in Boulder, Utah to discuss the formation of a partnership to combat the invasive exotic Russian olive, which was rapidly invading riparian zones along the Escalante River. In addition to exotic plant control, the group also discussed other concerns in the watershed, including the status of the native fish, beaver re-introduction, and springs. The Escalante River Watershed Partnership was created following that meeting, and has evolved and developed over the last two years. Principal partners include the Bureau of Land Management, National Park Service, U.S. Forest Service, The Nature Conservancy, and the State of Utah. In all, some 25 federal, state and private partners are currently part of the group. The Partnership has succeeded due in part to decisions made early in its formation, including the use of open meetings, professional facilitation, consensus, and strong local outreach. Using The Nature Conservancy's Conservation Action Planning process, the ERWP has developed an Action Plan to guide efforts in the watershed. The first component from the Plan was the preparation of a woody invasive plant control plan, focusing on the removal of Russian olive from the watershed. Other committee-led efforts include outreach to the local public, coordination with the State of Utah on beaver re-introduction, work with the U.S. Forest Service on planning efforts on Dixie National Forest, and the re-introduction of native Colorado River cutthroat trout. Monitoring and adaptive management planning to evaluate various projects as well as the Partnership's overall progress is currently being completed.

\section{COLORADO RIVER RIPARIAN ECOSYSTEM REHABILITATION IN GLEN CANYON NATIONAL RECREATION AREA, ARIZONA}

Lawrence E. Stevens, Kelly J. Burke, John R. Spence, Lonnie Pilkington, and Christopher Hughes

The riparian zone of the Colorado River ecosystem in Glen Canyon National Recreation Area and Grand Canyon National Park has been highly altered by the construction and operations of Glen Canyon Dam since 1963, particularly through reduced flood frequency, reduced sediment transport, and colonization by non-native tamarisk (Tamarix spp.) and other species. Ecological rehabilitation requires a clear understanding of desired riparian conditions, flow regulation impacts, and non-flow stewardship options in relation to the National Park Service (NPS) mission and elevated public interest in the reach. Here we describe collaborative efforts and lessons learned over the past decade to plan and implement rehabilitation of 3 riparian study sites in relation to a control site, and test the hypothesis that such effects improve habitat structure and native populations in relation to NPS ecosystem goals.

Native vegetation cover at the Lees Ferry (LF) long-term rehabilitation site increased to $>80 \%$ within 3 yr by 2005, and native phreatophyte tree height exceeded $10 \mathrm{~m}$ after $10 \mathrm{yr}$. Avian diversity and herpetofaunal density there approached or exceeded that of the pretreatment tamarisk stand and at the Paria Beach control site within 3 yr; however, the small rodent assemblage at LF has remained a monoculture of cactus mouse (Peromyscus eremicus), lower in diversity than that of the control site or the as-yet-untreated Leopard Frog Marsh (LFM) site. Fencing is essential to protect plantings from beaver foraging. Recent manual removal of 2.5 ha of tamarisk from the remote, recently treated Hidden Slough site has resulted in greatly increased terrestrial invertebrate diversity, and vegetation and avian diversity are beginning to increase; however, small rodent diversity remains low. Rehabilitation 
planning is underway at LFM and includes potential reintroduction of extirpated northern leopard frog [Lithobates (Rana) pipiens], Niobrara ambersnail (Oxyloma h. haydeni), and several rare plant species. Collectively, these results demonstrate that rehabilitation of CRE riparian habitat can be rapid and effective, but not all taxa recover at equal rates. We discuss these findings in relation to dam operations and the rapid, on-going defoliation of tamarisk by the introduced Diorhabda spp. leaf beetles.

\section{ECOLOGICAL IMPACTS AND MANAGEMENT IMPLICATIONS OF INTRODUCED BISON IN THE GRAND CANYON REGION}

Evan Reimondo, Thomas Sisk, and Tad Theimer

The plains bison (Bison bison bison) is an American icon and an animal of conservation priority, but it is also a large ungulate that can have significant impacts on plant communities. A herd of plains bison recently colonized the portion of the Kaibab Plateau, Arizona, administered by Grand Canyon National Park (GRCA). This herd is descended from animals introduced to the region in an early cattlebison breeding experiment, and genetic tests demonstrate a high level of cattle gene introgression. The herd is now managed as a valued wildlife game species by the Arizona Game and Fish Department on Forest Service land in the neighboring House Rock Valley. GRCA managers consider bison to be nonnative and are concerned that bison are degrading park resources, including sensitive springs, seeps, and pond habitats. Uncertainty regarding these effects has been a point of disagreement and conflict in interagency discussions. We quantified the effects of bison on spring and pond wetland vegetation within GRCA, and found that as evidence of bison use increased, vegetative cover was decreased by 70 $90 \%$, vegetative height across functional groups decreased to $25 \%$ of that in low- or non-use sites, and bare soil increased to $40-50 \%$. Plant responses monitored within and outside two bison exclosures mirrored these effects within 2 yrs of establishment. GRCA will need to decide whether these effects are beyond the acceptable range of impacts for the national park, and therefore require management actions to mitigate bison impacts. We advocate the continuation of an ongoing collaborative process, based on strong and transparent science, to find mutually amenable management approaches and solutions for the managing agencies.

\section{AGE AND SEX COMPOSITION OF HARVEST AND TIMING OF BIRTH FREQUENCY FOR ARIZONA MOUNTAIN LIONS}

Brian F. Wakeling, Ronald L. Day, Amber A. Munig and Jack L. Childs

We studied harvest characteristics and birth frequencies for mountain lions (Puma concolor) in Arizona to develop possible harvest strategies that could be used to address a declining mountain population that was not consistent with management objectives (i.e., when the management objective was not to decrease the population). We examined 1,138 mountain lions harvested in Arizona during 2005-2010 to determine if mean age and sex of harvested mountain lions differed between hunters that used hounds for pursuit and those that did not. We also examined 38 photographs (22 of kittens, 16 of mountain lion pairs) obtained from 174 camera traps deployed for 60,117 trap nights in 3,320 calendar days during 2000-2009 to estimate birthing dates in Arizona and to identify the period in which the greatest likelihood existed for inadvertent orphaning of kittens during hunting activities. Harvest intensity may be inferred from harvest data because age and sex composition differs with exploitation intensity within individual populations, yet hunting method may influence harvest age and sex composition as well. Mean age of harvested mountain lions differed by method of harvest $(\mathrm{P}<0.001, \mathrm{~F}$ $=2.479)$, and hound hunters harvested significantly older males (3.6 yrs) than did boot hunters (3.0 yrs). Mean age of females harvested by boot hunters ( $3.2 \mathrm{yrs})$ and hound hunters $(2.9 \mathrm{yrs})$ did not differ from each other or from mean age of males harvested by either method. In southern Arizona, mountain lions 
seem to have the greatest frequency of births during December and July through October. If a mountain lion population declines contrary to management objectives, restrictions on the use of hounds may seem appealing because ease of implementation is greater than requiring all hunters to use hounds (not all hunters possess trained hunting hounds and such a restriction may necessitate the hiring of guides with trained hunting hounds). However, hound hunters seem more selective in harvest of males over females and in harvesting older-age males when compared with boot hunters. If populations are declining contrary to management objectives, closing mountain lion seasons or restricting method of take during specific time periods, such as July through December, may reduce incidental take of young. Step-wise implementation of management strategies, such as reducing season length, restricting hunting method, establishing female harvest objectives, and total closure of hunting seasons may be used to restore overexploited populations of mountain lions.

Keywords: Arizona, hunting, mountain lion, selective harvest

\section{EVALUATING THE EFFECTS OF MANAGEMENT ACTIONS ON RAZORBACK SUCKER RECOVERY IN THE SAN JUAN RIVER BASIN}

Scott L. Durst

I conducted a study to evaluate the effect of the San Juan River Basin Recovery Implementation Program's management actions on the recovery of endangered razorback sucker in the San Juan River. The San Juan River Basin Recovery Implementation Program manages flow from Navajo Dam to mimic a natural hydrograph in the San Juan River, stocks hatchery-reared razorback sucker to augment the razorback sucker population in the river, and removes non-native fish to minimize predation and competition on razorback sucker. I used long-term monitoring data to measure the response of razorback sucker to these management actions and used an information theoretic approach to evaluate the relative importance of the different management activities. While all management actions were supported in models predicting razorback sucker catch rates, the effect of stocking hatchery-reared razorback sucker appears to have the greatest effect on increasing razorback sucker populations in the San Juan River. The results of this analysis can inform the San Juan River Basin Recovery Implementation Program's adaptive management process and provide guidance for the revision or implementation of management actions that will lead to the eventual recovery of razorback sucker in the San Juan River Basin.

\section{CHALLENGES TO ESTABLISHING BASELINE CONDITIONS FOR LONG-TERM VEGETATION MONITORING IN NATIONAL PARKS ON THE SOUTHERN COLORADO PLATEAU}

James K. DeCoster, Jodi Norris and Megan C. Swan

In an effort to implement long-term monitoring of upland vegetation and soils in National Park Service (NPS) units across the southern Colorado Plateau, the Southern Colorado Plateau Inventory and Monitoring Network (SCPN) began establishing plots in key ecosystems in a number of parks in 2007. Annual variation in species abundance, driven in part by changes in precipitation, was expected, particularly in drier ecosystems. To capture this variation, we chose to establish a subset of plots in each targeted ecosystem and sample those plots for three or more consecutive years. This strategy allows for examination of both temporal and spatial variation, which will aid in developing revisit designs that maximize our ability to capture both temporal and spatial variation in species composition and also to detect change. However, by extending our baseline sampling over multiple years, a number of other unexpected factors came into play, causing additional variation to the baseline conditions. These included human disturbances, such as the implementation of a landscape restoration project, and natural 
disturbances, such as wildland fires. In addition, over this time period we detected vegetation changes beyond inter-annual precipitation-mediated fluctuations. These included increase in nonnative species abundance and shrub die-off. Temporal variability necessitates defining baseline conditions based on multiple years, but directional change and disturbance may interfere during that time period may interfere with the definition of the baseline.

\section{EXPECTED WILDFIRE SUPPRESSION COSTS FOR PROPOSED 4FRI TREATMENT AREAS} Ryan Fitch, Yeon-Su Kim and Amy Waltz

The Four Forest Restoration Initiative (4FRI) has proposed restoration treatments totaling 2.4 million acres across the ponderosa pine landscape of Arizona with the goal of mitigating the potential for severe, stand replacing fires. Our study will compare current wildfire behavior conditions across the landscape to the predicted wildfire behavior conditions associated with the proposed treatments in an effort to determine the monetary changes between expected wildfire suppression costs under current and treated forests. Previous studies have focused on the relationship between fire size and suppression costs, which showed a strong correlation. Our analysis focuses solely on changes in fire behavior characteristics associated with fire severity that can be affected through treatments to predict suppression costs because the relationship between fire characteristics and suppression costs has not been studied extensively before. Using the proposed treatment area on the Kaibab National Forest as a case study, we estimated total suppression costs range between $\$ 1,439,091$ and $\$ 2,454,471$ (2002 dollars) for areas classified with a risk of "severe" wildfire. Our ongoing research is modeling proposed treatment areas across the 4FRI landscape in relation to their potential fire behavior. Once this modeling is completed, we will be able to compare the reduction in fire severity associated with treatments against the fire severity of the current conditions.

\section{PLANNING AND IMPLEMENTING LANDSCAPE SCALE ARTHROPOD INVENTORY AND MONITORING PROJECTS}

\section{David C. Lightfoot}

Arthropods represent the most diverse group of organisms on the Colorado Plateau and throughout the Southwest, yet relatively little effort has been directed toward the inventory and monitoring of arthropods on the Colorado Plateau as compared to vascular plants and vertebrate animals. For scientists and natural resource managers to understand biotic diversity, biotic communities and ecosystem processes on landscapes of interest, they need to conduct arthropod inventory and monitoring studies. Arthropod inventory and monitoring present challenges due to the tremendous diversity of taxa, but those challenges can be resolved through careful planning. Inventory and monitoring protocols for plants and vertebrate animals are readily available, but no such resources are available for arthropods. This article presents an approach and protocols to planning and implementing landscape scale arthropod inventory and monitoring projects in semi-arid regions. Unlike plant and vertebrate inventory and monitoring, arthropod inventory and monitoring usually requires the recruitment of outside taxonomic experts for consultation relative to the selection of target taxa, advice for appropriate sampling protocols, and specimen identification. Arthropod inventory and monitoring also should include collaboration with a regional arthropod research museum to develop and archive voucher and reference specimen collections. Aspects of inventory and monitoring that are unique to arthropods are discussed, and an overall step-wise conceptual model to arthropod inventory and monitoring is presented. 
CROSS-JURISDICTIONAL MONITORING FOR NON-NATIVE PLANT INVASIONS USING NDVI CHANGE DETECTION INDICES IN WALNUT CANYON NATIONAL MONUMENT, ARIZONA, USA

Hillary L. Hudson, Steven E. Sesnie, Ronald D. Hiebert, Brett G. Dickson, and Lisa P. Thomas

Non-native invasive plants pose a significant threat to native biodiversity on National Park

Service (NPS) and other public lands, prompting active federal prevention and control programs. Within the NPS, park units are assisted by the Inventory and Monitoring (I \& M) Networks whose role is to provide long-term monitoring and limited research support to individual park management efforts. The Southern Colorado Plateau I \&M Network (SCPN) is currently testing methods for selecting monitoring locations to assist in the early detection and rapid control of priority non-native plant species including areas where there is a cross-jurisdictional threat to park resources.

In response to SCPN research needs, we sought to find if NDVI is capable of detecting locations invaded by non-native plants in a landscape possessed of diverse ownership and management regimes. We compared non-native species richness and non-native community composition to NDVI values and disturbance types with the expectation that high numbers of non-native plants would indicate disturbed locations that are a high monitoring priority. We hypothesized that sites with negative NDVI values would correspond to areas with increased non-native species richness and that disturbances resulting in decreased plant cover would be greatest in those locations.

Using difference maps (DMs) derived from Landsat 5 TM images, we classified five Normalized Difference Vegetation Index (NDVI) change value categories in the Geographic Information System. Using NDVI classes to stratify plots and delineate categories for statistical comparison, we collected non-native invasive plant community data and disturbance types in $150 \mathrm{~m} \mathrm{X} 150 \mathrm{~m}$ plots. We then used plot data collected in 2008 and 2009 to test the application of NDVI to the detection of gradients of disturbance and non-native invasive species richness at Walnut Canyon National Monument, a SCPN unit in Northern Arizona. In addition we compared three different analysis techniques (image subtraction, difference from average, and single year image dates temporally proximal to field data collection) and seasonally different image dates (August vs. October) to find which method and season had the best modeling potential.

Multi-Response Permutation Procedure and Analysis of Variance showed that NDVI DM change values were sensitive to differences in non-native species richness, non-native species community composition, disturbance type, and land ownership. Ordinary Least Squares regression analyses demonstrated that October 2009 NDVI image dates had the best fit to field data among three analyses methods and two different months. Though our expectation that negative NDVI values would correspond to disturbed areas with high numbers of invasive species was incorrect, the correlation between NDVI change values, management jurisdiction, disturbance, and non-native species richness indicates that satellite derived vegetation indices have potential applications for monitoring sites at a high risk to non-native invasion and for improving control efforts. Our research also demonstrated that collaboration between stakeholders is necessary to effectively meet the objectives of NPS non-native monitoring and control efforts.

THE INFLUENCE OF TAMARIX RAMOSISSIMA DEFOLIATION ON POPULATION MOVEMENTS OF THE NORTHERN TAMARISK BEETLE (DIORHABDA CARINULATA) WITHIN THE COLORADO PLATEAU

Levi R. Jamison, Charles van Riper III, and Dan W. Bean

The northern tamarisk beetle (Diorhabda carinulata) was introduced to the Colorado Plateau within the Colorado River Basin in 2004, in an effort to control invasive/exotic tamarisk (Tamarix 
ramosissima) plants. Since release, there has been rapid beetle colonization and subsequent defoliation of tamarisk along the Colorado River corridor. We collected plant phenology and beetle abundance data from the Dolores and San Juan rivers, two major tributaries of the Colorado River, to document tamarisk defoliation and beetle movement patterns. We found $D$. carinulata population movement patterns to be highly influenced by the availability of food resources, with local beetle boom and bust events appearing common. Beetles were able to defoliate from 35-65 km of river corridor tamarisk habitat each year. Following intensive tamarisk defoliation of large riparian reaches, beetles displayed a pattern of temporary abandonment in the following year with recolonization of that habitat in the subsequent year. Larvae were found primarily in areas that had partial defoliation, while adults occurred throughout the river corridor but most often on the leading edge of defoliated habitats. Understanding this type of beetle behavior and movement patterns will be useful in the management of areas where $D$. carinulata has been established, and in areas where it has not yet colonized. This will also assist land managers to further understand how defoliation and the presence of $D$. carinulata influence tamariskdominated habitats within Colorado Plateau riparian ecosystems.

\section{SURVIVAL, SPRING HUNTING, AND CAUSE-SPECIFIC MORTALITY FOR MALE MERRIAM'S TURKEYS IN NORTH-CENTRAL ARIZONA}

\section{Brian F. Wakeling and Rick Langley}

We caught and radiomarked 26 male Merriam's turkeys (Meleagris gallopavo merriami) near Pinetop in north-central Arizona during 2010 and 2011 to determine the level of hunting-related mortality within a management area with liberalized spring turkey hunting seasons for youth. Hunting seasons had been liberalized to allow more young hunters to participate in spring turkey hunting seasons, which could increase youth hunter recruitment. Yet some adult hunters expressed concern about reductions in hunt quality in standard seasons that followed the youth seasons and potential increases in male turkey harvest. We detected 3 mortalities due to predation, 2 to youth turkey hunters, 3 to adult turkey hunters, one to a vehicle collision, and 3 to unknown causes. Our data indicate that hunter harvest levels are within accepted biological tolerances within our study area. The dissatisfaction expressed by some hunters that select this area in which to hunt seems to be primarily based on personal perception rather than biological reality. Hunter recruitment and retention efforts need to balance perceived hunt quality in an effort to retain existing hunters, while providing adequate opportunity with which to recruit new hunters.

Keywords: cause-specific mortality, hunter recruitment and retention, Meleagris gallopavo merriami, survival, youth hunter

\section{SPATIAL FACTORS INFLUENCING HIGH PROBABILITY AREAS FOR NUISANCE BLACK BEAR COMPLAINTS IN ARIZONA (2000-2010)}

Daniel P. Sturla, Brian F. Wakeling and Michael J. Rabe

We analyzed spatial trends associated with nuisance black bear complaints during 2000-2010 within Arizona to determine which physiographic, climatic, and local conditions contributed to the likelihood of a complaint. The Arizona Game and Fish Department (Department) annually receives hundreds of calls regarding human-bear conflicts which result in the expenditure of hundreds of human resource hours during responses. Resulting actions by the Department include providing deterrent information, capture and release of low public safety risk bears, or euthanization of high public safety risk bears. Public relations issues surrounding these actions are often controversial and the loss of individual bears through administrative euthanization is undesirable. We analyzed data associated with 1,471 nuisance bear complaints filed with the Department. Nuisance bear accounts were defined as a 
human-bear encounter followed by a complaint to the Department. We assigned variables that describe the municipalities, climate, and physical locations to a dataset of nuisance bear complaints and analyzed them in a stepwise logistic regression analysis. A training set of 1,800 total points was $87.9 \%$ accurate identify problematic locations, whereas as a test set of 1,142 points was $85.3 \%$ accurate. The probability of a reported human-bear conflict increased with greater distance from chaparral habitat associations, greater distance from oak habitat associations, greater distance from public land, greater average minimum temperature, greater mean annual precipitation, greater distance from a landfill, and greater human population density. However, the probability of a reported conflict also increased with closer proximity of aspen habitat associations, ponderosa pine habitat associations, private land, major roads, and perennial water sources. As humans continue to develop and inhabit the urban-wildland interface, human-bear conflicts may increase. Identifying locations where nuisance complaints have a high probability of occurrence and the factors that influence that increased probability will help managers, elected officials, and private citizens determine actions that may reduce the frequency of human-bear conflicts.

Keywords: Arizona, black bear, human-bear interaction, nuisance

BEE DIVERSITY AND ABUNDANCE ALONG AN ELEVATIONAL GRADIENT IN NORTHERN ARIZONA

David R. Smith, Jacob Higgins, Jacob Burton and Neil Cobb

There is increasing evidence that native pollinators are declining prompting a greater need to understand the potential impacts of climate change on bee communities. Elevation gradients are natural laboratories for the study of climate change because elevation zones can serve as proxies for climate zones. Thus, studying changes in species-to-community responses across an elevational gradient can help researchers predict species and community level responses to various potential climate change scenarios. The Colorado Plateau in northern Arizona provides a wide elevational gradient that covers numerous vegetation communities. These communities are predicted to experience increasing temperature and increased intensities of summer precipitation caused by climate change. Therefore it is critical to obtain current baseline information on bee species distribution and community composition in order to better predict future climate change impacts. The entirety of species in these communities is currently unknown, as are population dynamics for even the most common of species.

Native bees were sampled along a vegetation landscape from Desert Shrubland to Mixed Conifer along a 3,200 meter (m) elevational gradient north of the San Francisco Peaks in Coconino County, Arizona. We found three general patterns; 1) the 117 bee species recorded were more abundant and diverse with decreasing elevation; 2) Abundance and diversity both were greatest during the summer monsoon season, especially at lower elevations, and a smaller abundance peak occurred in the spring at all study sites; and 3) the bee fauna was composed mostly by rarely sampled species and species restricted to one or two habitats; only five species occurred at all five elevations. The degree of specialization and incidence was greatest at the highest study site sampled, the Mixed Conifer site. We present baseline information on current bee populations that may be used in future climate change investigation on this portion of the Colorado Plateau.

BLACKBRUSH (COLEOGYNE RAMOSISSIMA TORR.): STATE OF OUR KNOWLEDGE AND FUTURE CHALLENGES.

Rosemary L. Pendleton, Burton K. Pendleton, Susan E. Meyer, Bryce Richardson,, Todd Esque, and Stanley G. Kitchen 
Blackbrush is a regionally dominant shrub species found in the transition zone between North American warm and cold deserts, where it occupies millions of hectares on National Park Service, Bureau of Land Management and National Forest System lands. Blackbrush habitat is under severe threat of loss from the combined effects of exotic annual grasses, increased fire frequency and rapid climate change. Attempts to restore blackbrush habitat have met with limited success. This manuscript synthesizes existing information on blackbrush biology and ecology, with the goal of guiding successful restoration efforts. Recent genetic work has revealed the existence of two metapopulations corresponding to Mojave and Colorado Plateau regions. This work, along with germination and reciprocal transplant studies, demonstrates the need for using appropriate seed sources. Blackbrush plants produce large seed crops infrequently, however seed can be stored for 10-12 years with minimal loss of viability. Establishment success may be enhanced by planting seeds in the fall to meet chilling requirements, and in small groups at $2.5-4.0 \mathrm{~cm}$ depth to mimic rodent caches. Current observations and projected changes in climate suggest that attempts to restore blackbrush at lower elevations of its current distribution would be unlikely to succeed. Common garden experiments under multiple climate conditions will give us a better understanding of climatic tolerances. Further research is needed to develop new and better restoration techniques.

\section{NEW METHODS AND HIERARCHICAL MODELS FOR ESTIMATING INTENSITY OF DIURNAL SPACE AND HABITAT USE BY MERRIAM'S TURKEY IN MANAGED FORESTS OF NORTHERN ARIZONA.}

\section{Brett G. Dickson, Vincent J. Frary, Steven E. Sesnie, Jill M. Rundall and Michael F. Ingraldi}

The response of native wildlife species to habitat change and the increased pace of large-scale forest restoration and fuels reduction treatments in managed forests of the southwestern USA is not well studied. Thus, there is a pressing need to develop contemporary statistical models for evaluating the effect of these activities on animal populations prior to extensive and rapid habitat modification, while accounting for small sample sizes typical of many field efforts. We used a maximum likelihood-based modeling framework to estimate seasonal intensity of space and habitat use during diurnal periods by a population of Merriam's turkey occupying a ponderosa pine-dominated forest in northern Arizona. Using model selection and multi-model inference, we fitted hierarchical models that were capable of leveraging high-resolution global positioning system data on turkey's, accounted for spatial and temporal structuring in these location data, and incorporated multiple random effects. We considered a modest number of key habitat variables (i.e., fixed effects) in these models that were specified a priori by a group of experts on the species, and included custom derived, high-resolution forest structure attributes. On average, fixed kernel estimates of summer home range and core area use were larger than winter estimates. Relationships between the intensity of use and habitat variables were different in each season, and custom, digitally derived estimates of forest structure and vegetation often were strong predictors. In both seasons, turkeys intensively used areas closer to small canopy gaps and less intensively used areas with high densities of forest edge or that were proximate to tertiary roads. Low and intermediate values of the Normalized Difference Vegetation Index (NDVI), derived as a surrogate measure of the amount of deciduous or herbaceous understory vegetation on a site, also were important predictors of use in the summer and winter, respectively. Individuals intensively used canyon bottom and steeper terrain at higher elevations, as well as areas closer to water in the summer. During the winter season, we detected a strong positive relationship with areas that were thinned or burned in previous years. Our results provide insight into which forest or habitat parameters are contributing to the intensity of habitat use by Merriam's turkey, and will help to mitigate against the adverse timing or targeting of 
these activities. Our statistical and spatially explicit modeling approach is highly transferable to the management and conservation of other species and ecosystems.

ASSOCIATIONS OF ELEVATION, VEGETATION TYPE AND LIVESTOCK GRAZING WITH THE DISTRIBUTION OF THE WUPATKI POCKET MOUSE (PEROGNATHUS AMPLUS CINERIS) Jean Marie Loverich Rieck, Sharalyn K. Peterson and Tad C. Theimer

The Wupatki pocket mouse, a subspecies of the Arizona pocket mouse, is a species of concern in the Arizona Heritage Data Management System and a Group 4 species on the Navajo Endangered Species List, but the limits of its geographical range and habitat associations are poorly known. We analyzed data collected between 2002-2004 and conducted live-trapping surveys at 32 sites in and around Wupatki National Monument during summer 2011 to determine how this subspecies' distribution was related to elevation, livestock grazing, and dominant plant community type. Our analyses indicated that the Wupatki Pocket Mouse was 1) most abundant between 1400-1600m, 2) more abundant on ungrazed than grazed plots, and 3) not strongly associated with any of the 6 major plant associations within the monument. These data suggest that models predicting future distribution of this subspecies under climate change should be based more on predicted changes in temperature rather than on shifts in specific plant associations, and should include the potential negative impacts of grazing.

\section{BEETLE DIVERSITY OF THREE MANAGEMENT ZONES IN SALT CREEK CANYON,} CANYONLANDS NATIONAL PARK, UT

Louis. L. Pech and Timothy. B. Graham

Salt Creek Canyon in Canyonlands National Park (CANY), Utah has historically been subject to off-road vehicle use. Portions of the canyon were closed recently, thus dividing Salt Creek Canyon into three management zones: an upper No Road (NR) section, where vehicle use ended in 1964, a middle Closed Road (CL) section, where vehicle use ended in 1998, and a lower Road Open (RO) section, where vehicle use continues. Here we present descriptions of beetle diversity in these management zones. Beetles were collected each June from 2000-2007 at four sites designated RO3, CL1, CL10 and NR2. Non-metric multidimensional scaling (NMS) indicates that all sites overlap on axis-1, but site RO3 is resolved from the other three sites on axis-3 and NR2 is resolved from the other three sites on axis-2. NMS also revealed substantial inter-annual variation in assemblages at each site, with NR2 supporting the most stable assemblage. Joint plots identified several morphospecies that provided the structure of the NMS plots. In addition, several weather variables were correlated with the structure of the ordination. These results indicate that the three management zones support beetle assemblages whose dynamics are influenced, probably indirectly, in part, by weather variables. It is not clear what role past and/or current vehicle use of the different reaches of Salt Creek plays in beetle community dynamics.

STANDING WATER IS POSITIVELY CORRELATED WITH INVERTEBRATE BIOMASS, NESTLING FEEDING RATE AND PRODUCTIVITY IN SOUTHWESTERN WILLOW FLYCATCHERS (EMPIDONAX TRAILLII EXTIMUS)

\section{Peterson, A.R. Pellegrini, M.A. McLeod and T.C. Theimer}

Presence of standing water is often listed as an important component of Southwestern Willow Flycatcher habitat but the mechanism for this relationship is poorly understood. We used field observations to test whether food availability (biomass of aerial invertebrates) and nestling provisioning rates varied with distance from standing water We then used a longer-term data set to test whether three 
indices of habitat quality (nest initiation date, clutch size and nest productivity) were higher in nests placed near standing water. We found that 1) invertebrate biomass decreased with increasing distance to standing water, 2) Willow Flycatcher parents provisioned nestlings at a higher rate as distance to water decreased and 3) nests within $10 \mathrm{~m}$ of standing water were initiated earlier and had higher clutch sizes and fledgling success. These results indicate that for some Willow Flycatcher populations patterns of inundation throughout the breeding season may drive invertebrate prey availability and habitat quality.

\section{ANT COMMUNITY STRUCTURE IN SALT CREEK, CANYONLANDS NATIONAL PARK,} UTAH: CHANGES AT 4 SITES IN JUNE SAMPLES 2000-2007.

Tim B. Graham and Evelyn Cheng

In 1998, $14 \mathrm{~km}$ of Salt Creek in the Needles District of Canyonlands National Park, Utah, were closed by U.S. District Court. Approximately $5 \mathrm{~km}$ of road in the stream channel remained open downstream from the $14 \mathrm{~km}$ closed section; Salt Creek upstream this closed reach has been vehicle-free since at least the early 1970's. In 2000, we established a study of terrestrial arthropod community composition in the open road, closed road, and long-closed (referred to as no road) segments of Salt Creek. Here we present data on changes in June ant community structure from 2000 to 2007 at four sites: an open road site (RO3), two closed road sites, one at the downstream end (CL1) and one at the upstream end (CL10) of the closed section, and one no road site (NR2). More than 15,200 ants (including alates) were collected during the study, representing 17 genera; as few as 96 (CL1, 2007) and as many as 1588 (NR2, 2006) ants were collected at a site in a single month. RO3 averaged fewer ants collected per year (392) than the other sites, and NR2 averaged the most total ants collected per year (595). NMS analysis showed very distinct separation of the RO3 ant community from the other three sites; CL1 and CL10 communities were fairly similar to each other but distinct from NR2 as well. Communities were structured primarily by presence or absence of one or two genera; ordination scores were also related to average annual maximum temperatures and total annual precipitation.

Keywords: Ants, Formicidae, community structure, riparian ecosystems, off-road vehicles, Canyonlands National Park, Utah 


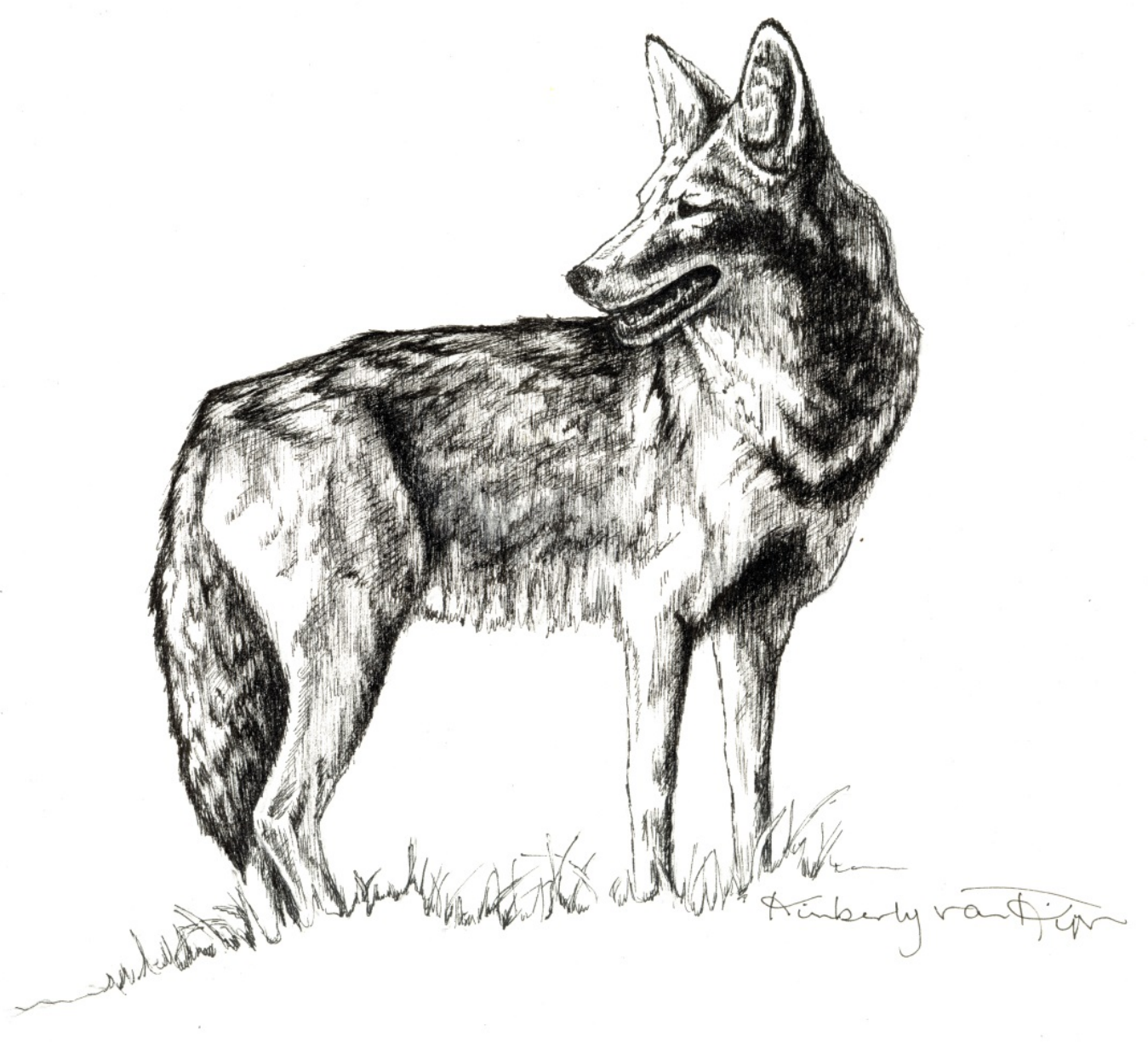

Drawing of coyote, Canis latrans (copyright and courtesy of Kimberly Ann van Riper). 
ISSN 2331-1258 (online)

http://dx.doi.org/10.3133/XXXX/ofr20151115 